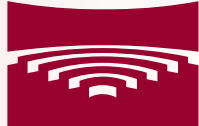

Rīgas STRADINA UNIVERSITĀTE

\title{
Toms Pulmanis
}

\section{AR PUSAUDŽU PAŠNĀVNIECISKO UZVEDĪBU SAISTİTIE FAKTORI LATVIJĀ}

Promocijas darbs medicīnas doktora zinātniskā grāda iegūšanai Specialitāte - sabiedrības veselība un epidemioloǵija 
Toms Pulmanis

\title{
AR PUSAUDŽU PAŠNĀVNIECISKO \\ UZVEDĪBU SAISTĪTIE FAKTORI LATVIJĀ
}

\author{
Promocijas darbs \\ medicīnas doktora zinātniskā grāda iegūšanai
}

Specialitāte - sabiedrības veselība un epidemiologija

Darba zinātniskais vadītājs:

Dr. med. profesors Māris Taube

Rīga, 2019 


\begin{abstract}
ANOTĀCIJA
Ievads. Pašnāvības ir viena no būtiskākajām sabiedrības veselības problēmām Latvijā pēc standartizētās mirstības rādītājiem Latvija ierindojas augstajā otrajā vietā ES dalībvalstu vidū. Būtisks pabeigtas pašnāvības riska faktors ir pašnāvnieciska uzvedība, t.sk. domas par pašnāvību un pašnāvības mēǵinājumi, kas iezīmē risku pabeigtai pašnāvībai, bieži tiek izmantota asociēto riska faktoru pētniecībā un ir īpaši aktuāla pusaudžu populācijās. Ar ǵimenes vidi saistītajiem, vienaudžu vidi raksturojošajiem un individuālajiem faktoriem var būt nozīmīga loma saistībā ar pusaudžu pašnāvniecisko uzvedību, jo īpaši ņemot vērā faktu, ka vairāku šo faktoru izplatība Latvijā vērtējama kā augsta.

Darba mērḳis bija izpētīt pašu ziṇotās pašnāvnieciskās uzvedības izplatību un saistību ar gimenes un vienaudžu vides raksturojošiem faktoriem, kā arī individuālajiem faktoriem 14-17 gadus vecu pusaudžu populācijā Latvijā.

Materiāls un metodes. Darbā izmantoti dati, kas iegūti reprezentatīvā šḳērsgriezuma pētījumā "Eiropas skolu aptaujas projekts par alkoholu un citām narkotiskajām vielām". Pētījuma instruments bija aprobēta, standartizēta aptaujas anketa. Kopumā promocijas darbā analizēti dati par 7299 respondentiem. Statistiskajā datu apstrādē izmantots biežumu sadalījums, šḳērstabulas un Hī kvadrāta $\left(\chi^{2}\right)$ tests. Saistību noteikšanai izmantotas nesamērotās izredžu attiecības, Spīrmena korelācijas koeficients un daudzfaktoru log̣istiskā regresija.

Rezultāti. Domas par pašnāvību dzīves laikā atzīmējuši 15,7\% Latvijas 14-17 gadus veco pusaudžu - 11,7\% zēnu un 19,4\% meiteņu, bet pašnāvības mēǵinājumu dzīves laikā atzīmējuši $8,2 \%$ pusaudžu - 5,9\% zēnu un 10,2\% meiteṇu. Domu par pašnāvību izplatība ir augstāka to pusaudžu vidū, kuri savas gimenes materiālo stāvokli salīdzinājumā ar citām ǵimenēm Latvijā vērtē kā sliktāku - meiteņu vidū šādi vērtēta ǵimenes materiālā stāvokḷa gadījumā vērojama arī augstāka pašnāvības mēginājumu izplatība.

Ar gimenes vidi saistītie faktori, kas neatkarīgi paaugstina izredzes domām par pašnāvību abās dzimumu grupās ir pašnāvnieciska pieredze gímenē, fiziska vardarbība gimenē, reti/nekad un dažreiz izjusts vecāku emocionālais atbalsts, bet atsevišķi zēniem nedzīvošana ar abiem bioloğiskajiem vecākiem. Ar ǵimenes vidi saistītie faktori, kas neatkarīgi paaugstina izredzes pašnāvības mēǵinājumam abās dzimumu grupās ir pašnāvnieciska pieredze ǵimenē, fiziska vardarbība ǵimenē, reti/nekad izjusts vecāku emocionālais atbalsts un nedzīvošana ar abiem bioloǵiskajiem vecākiem, bet atsevišḳi zēniem - seksuāla uzmākšanās g̣imenē un atsevišḳi meitenēm - dažreiz izjusts vecāku emocionālais atbalsts.
\end{abstract}


Ar vienaudžu vidi saistītie faktori, kas neatkarīgi paaugstina izredzes domām par pašnāvību abās dzimumu grupās ir pašnāvnieciska pieredze vienaudžu vidū, vienmēr/bieži un dažreiz piedzīvota ņirgāšanās skolā, bet atsevišķi meitenēm - reti/nekad un dažreiz izjusts vienaudžu emocionālais atbalsts. Ar vienaudžu vidi saistītie faktori, kas neatkarīgi paaugstina izredzes pašnāvības mēǵinājumam abās dzimumu grupās ir pašnāvnieciska pieredze vienaudžu vidū, vienmēr/bieži un dažreiz piedzīvota ṇirgāšanās skolā, bet atsevišḳi meitenēm - reti/nekad izjusts vienaudžu emocionālais atbalsts.

Individuālie faktori, kas neatkarīgi paaugstina izredzes domām par pašnāvību abās dzimumu grupās ir augsts un vidēji augsts depresijas simptomu līmenis, zems un vidēji zems pašcieņas līmenis, narkotiku lietošana dzīves laikā un ikdienas smēkēšana, bet atsevišķi meitenēm - neapmierinātība un vidēja apmierinātîba ar savu veselības stāvokli, kā arī riskanta alkohola lietošana dzīves laikā. Individuālie faktori, kas neatkarīgi paaugstina izredzes pašnāvības mēgeinājumam abās dzimumu grupās ir augsts un vidēji augsts depresijas simptomu līmenis, zems un vidēji zems pašcieņas līmenis, ikdienas smēḳēšana un neapmierinātība ar savu veselības stāvokli, atsevišḳi meitenēm - riskanta alkohola lietošana dzīves laikā, bet atsevišḳi zēniem - narkotiku lietošana dz̄ives laikā.

Secinājumi. Pašnāvniecisku uzvedību dzīves laikā atzīmē ievērojams īpatsvars Latvijas 14-17 gadus vecu pusaudžu, pašnāvnieciskās uzvedības veidu izplatība ir augstāka meiteņu vidū. Pastāv nozīmīga saikne starp pusaudžu pašnāvniecisko uzvedību un gan ar ǵimenes vidi saistītajiem, gan vienaudžu vidi raksturojošajiem, gan individuālajiem faktoriem, kas kas jāṇem vērā gan sabiedrības psihiskās veselības politikas veidošanā, gan pašnāvību profilakses intervenču plānošanā pusaudžu populācijā. 


\begin{abstract}
Introduction. Suicides are one of most relevant public health problems in Latvia standardised suicide mortality rates rank Latvia at the high second place among the European Union countries. An important risk factor for completed suicide is suicidal behavior, including suicidal ideation and suicide attempts, that is a risk factor for completed suicide and is often used in research of associated risk factors and is esspecially relevant in adolescent populations. Factors related to family environment, peer environment and individual factors have an important role in relation with adolescent's suicidal behavior, in particular taking in consideration the fact that prevalence of several of these potential risk factors in Latvia is estimated as high.

The aim of the Thesis was to assess prevalence of self-reported suicidal behaviour and its association with family and peer environment related factors, as well as individual factors in the population of 14 to 17-year-old adolescents in Latvia.

Material and methods. Data from representative cross-sectional study "European School Survey Project on Alcohol and Other Drugs" was used, including the data about 7,299 respondents. The instrument of the study was approbated standardised survey questionnaire. Statistical data processing was based on frequency distribution, cross tabulation and ChiSquare $\left(\chi^{2}\right)$ Test. To assess the associations odds ratio, Spearman's rank correlation coefficient and multiple logistic regression was used.

Results. Suicidal ideation during lifetime have been noted by $15.7 \%$ of Latvian 14-17year-old adolescents $-11.7 \%$ boys and $19.4 \%$ girls, while suicide attempts during their life time have been noted by $8.2 \%$ of aldolescents $-5.9 \%$ boys and $10.2 \%$ girls. The prevalence of suicidal ideation was higher among adolescents who evaluate their family's material status as low; among girls also a higher prevalence of suicide attempts was observed among respondents who evaluated material status as low.

Factors related to family environment that independently increase the odds for suicidal ideation in both gender groups are suicidal experience in the family, domestic physical violence, rarely/never and sometimes experienced emotional support from parents, but separately for boys - not living with both biological parents. Factors related to family environment that independently increase the odds for suicide attempt in both gender groups are suicidal experience in the family, domestic physical violence, rarely/never experienced emotional support from parents and not living with both biological parents, but separately for boys - sexual harassment in the family and separtealy for girls - sometimes experienced emotional support from parents.
\end{abstract}


Factors related to peer environment that independently increase the odds for suicidal ideation in both gender groups are suicidal experience among peers, always/often and sometimes experienced bullying at school, but separately for girls - rarely/never and sometimes experienced emotional support from peers. Factors related to peer environment that independently increase the odds for suicide attempt in both gender groups are suicidal experience among peers, always/often and sometimes experienced bullying at school, but separately for girls - rarely/never experienced peer emotional support.

Individual factors that independently increase the odds for suicidal ideation in both gender groups are high and moderately high level of depressive symptoms, low and moderately low level of self-esteem, lifetime drug use and current smoking, but separately for girls - dissatisfaction and moderate satisfaction with own health and lifetime alcohol intoxication. Individual factors that independently increase the odds for suicide attempt in both gender groups are high and moderately high level of depressive symptoms, low and moderately low level of self-esteem, current smoking and dissatisfaction with own health, but separately for girls - alcohol intoxication in lifetime and separately for boys - lifetime drug use.

Conclusions. Significant proportion of Latvian 14-17-year-old adolescents report lifetime suicidal ideation and suicide attempts, both types of suicidal behavior are more prevalent among girls. Significant association exists between suicidal behavior and factors related to family environment, peer environment and individual factors. It sould be taken into consideration during the development of public mental health policy and in the planning of the suicide prevention interventions in adolescent population. 


\section{SATURA RĀDĪTĀJS}

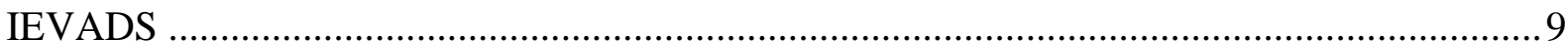

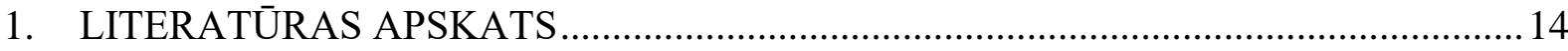

1.1. Pašnāvnieciskās uzvedības jēdziens un problēmas aktualitāte pašnāvību kontekstā..... 14

1.2. Pusaudžu pašnāvnieciskās uzvedības kopējā izplatība un izplatība pusaudžu

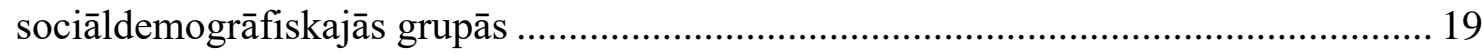

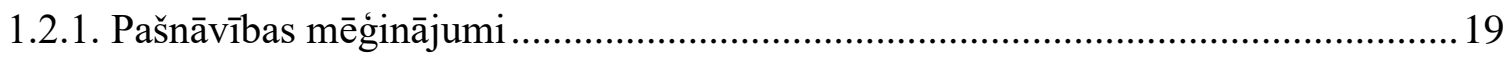

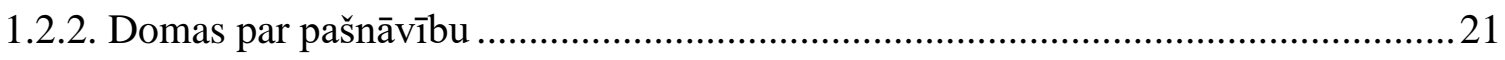

1.2.3. Pašnāvnieciskā uzvedība un g̊imenes materiālais stāvoklis ..................................23

1.3. Pašnāvnieciskā uzvedība un ar gimenes vidi saistītie faktori ....................................25

1.3.1. Pašnāvnieciskā uzvedība un nedzīvošana ar abiem bioloğiskajiem vecākiem .......25

1.3.2. Pašnāvnieciskā uzvedība un vecāku emocionālais atbalsts....................................2 27

1.3.3. Pašnāvnieciskā uzvedība un pašnāvnieciska pieredze g̊imenē ..............................29

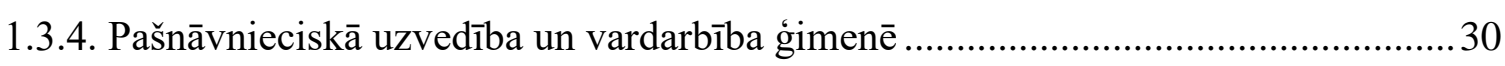

1.4. Pašnāvnieciskā uzvedība un ar vienaudžu vidi saistītie faktori ................................... 33

1.4.1. Pašnāvnieciskā uzvedība un vienaudžu emocionālais atbalsts ............................... 33

1.4.2. Pašnāvnieciskā uzvedība un pašnāvnieciska pieredze vienaudžu vidū................... 34

1.4.3. Pašnāvnieciskā uzvedība un vienaudžu ņirgāšanās............................................... 36

1.5. Pašnāvnieciskā uzvedība un pusaudža individuālie faktori ........................................ 38

1.5.1. Pašnāvnieciskā uzvedība un depresija................................................................ 38

1.5.2. Pašnāvnieciskā uzvedība un pašcieņa ................................................................ 40

1.5.3. Pašnāvnieciskā uzvedība un veselības pašvērtējums ........................................... 41

1.5.4. Pašnāvnieciskā uzvedība un atkarību izraisošo vielu lietošana ............................. 43

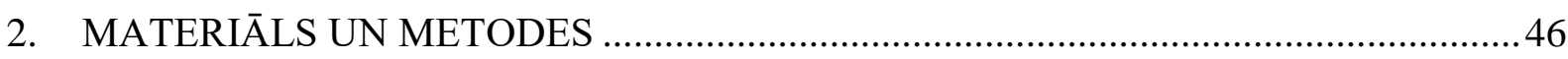

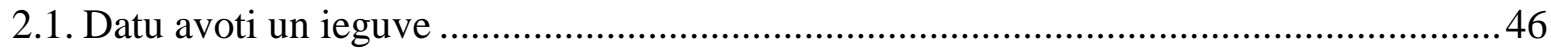

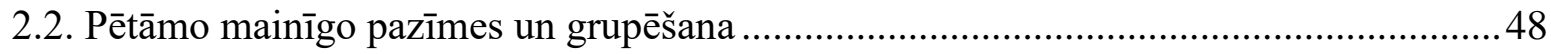

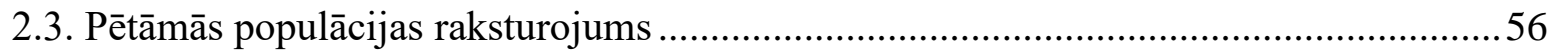

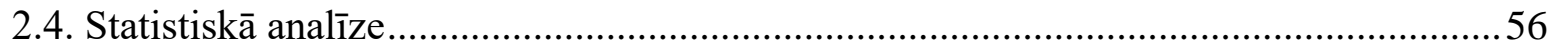

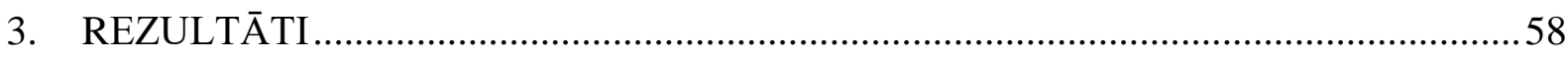

3.1. Pašnāvnieciskā uzvedība sociāldemogrāfiskajās grupās ..............................................58

3.1.1. Domas par pašnāvību sociāldemogrāfiskajās grupās ...............................................58

3.1.2. Pašnāvības mēǵinājumi sociāldemogrāfiskajās grupās............................................ 60

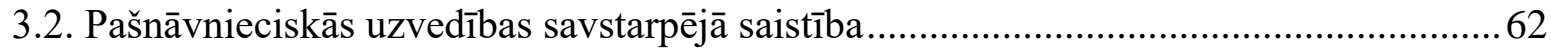

3.3. Pašnāvnieciskā uzvedība un ar g̊imenes vidi saistītie faktori .......................................62

3.3.1. Domas par pašnāvību un ar gimenes vidi saistītie faktori...................................... 64

3.3.2. Pašnāvības mēǵinājumi un ar ǵimenes vidi saistītie faktori ................................. 72 
3.4. Pašnāvnieciskā uzvedība un ar vienaudžu vidi saistītie faktori 80

3.4.1. Domas par pašnāvību un ar vienaudžu vidi saistītie faktori................................... 81

3.4.2. Pašnāvības mēǵinājumi un ar vienaudžu vidi saistītie faktori ................................ 87

3.5. Pašnāvnieciskā uzvedība un individuālie faktori .......................................................93

3.5.1. Domas par pašnāvību un individuālie faktori ...................................................... 95

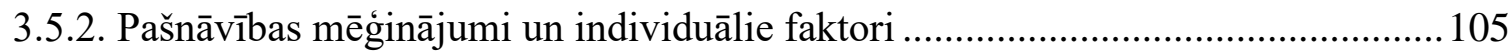

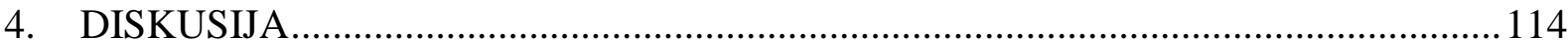

4.1. Pašnāvnieciskās uzvedības izplatība pusaudžu sociāldemogrāfiskajās grupās ...........114

4.2. Pašnāvnieciskā uzvedība un ar gimenes vidi saistītie faktori .....................................117

4.3. Pašnāvnieciskā uzvedība un ar vienaudžu vidi saistītie faktori ................................120

4.4. Pašnāvnieciskā uzvedība un individuālie faktori......................................................122

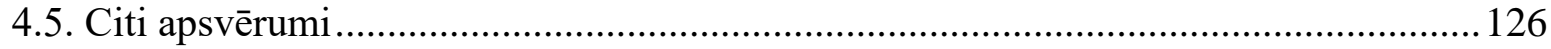

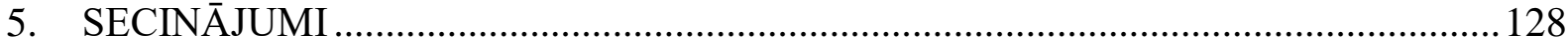

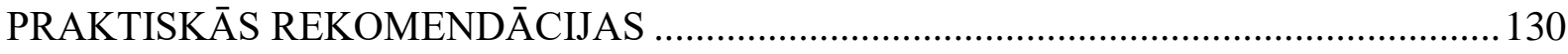

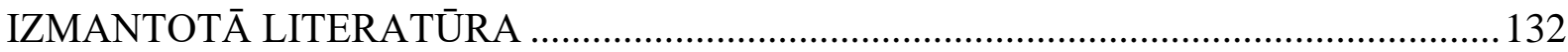

PUBLIKĀCIJAS UN TĒZES PAR DARBA TĒMU ….................................................. 143

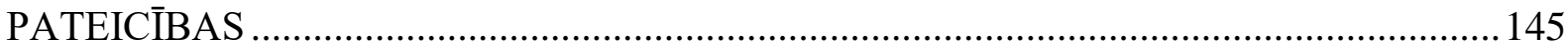

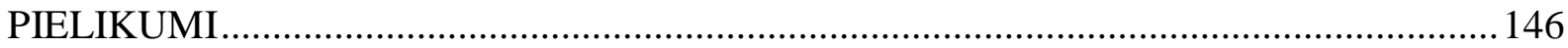




\section{DARBĀ LIETOTIE SAĪSINĀJUMI}

ASV Amerikas Savienotās Valstis

CES-D Epidemiologisko pētījumu centra Depresijas skala (Centre for Epidemiological Studies Depression Scale)

EK Eiropas Komisija

ES Eiropas Savienība

ESPAD Eiropas skolu aptaujas projekts par alkoholu un citām narkotiskajām vielām (European School Survey Project on Alcohol and Other Drugs)

IZM Izglītības un zinātnes ministrija

MK Ministru kabinets

OR izredžu attiecība (odds ratio)

PVO Pasaules Veselības organizācija

VIF dispersijas inflācijas faktors (variance inflation factor) 


\section{IEVADS}

Globālā mērogā pašnāvības vairs netiek uzskatītas tikai par cilvēku individuālu problēmu, bet gan par vienu no būtiskākajiem problēmjautājumiem un izaicinājumiem sabiedrības veselības un labklājīibas kontekstā. Pašnāvību problēmas aktualitāti papildus akcentē fakts, ka pašnāvības bieži skar darbspējīgos iedzīvotājus, radot zaudējumus ǵimenēm un valstu ekonomikai kopumā. Neskatoties uz pašnāvību cēloṇiem un negatīvo ekonomisko ietekmi valstu līmen̄̄, katra cilvēka zaudējums, nenoliedzami, ir traǵēdija pašnāvībā mirušā cilvēka ğimenei, draugiem un valstij kopumā (Taube un Damberga, 2009).

Pasaulē pašnāvībās ik gadu mirst teju 800000 cilvēku, un tas ir viens pašnāvības upuris katrās 40 sekundēs. Vēl ievērojami lielāks ir to cilvēku skaits, kas izdara pašnāvības mēǵinājumus. Lai arī pašnāvības izdara cilvēki dažādās vecuma grupās, globāli pašnāvība ir otrais biežākais nāves cēlonis 15-29 gadu vecuma grupā (World Health Organization [WHO], 2018a).

Pašnāvības ir viena no būtiskākajām sabiedrības veselības problēmām arī Latvijā - pēc standartizētās mirstības rādītājiem kopējā populācijā Latvija ierindojas otrajā augstākajā vietā ES dalībvalstu vidū (Šica, Pulmanis un Taube, 2017).

Problēmas aktualitāte un pašnāvību profilakses nozīme ir uzsvērta arī vairākos starptautiska un nacionāla līmeņa politikas plānošanas dokumentos, tajā skaitā PVO Psihiskās veselības rīcības plānā 2013.-2020. gadam (angl. - Mental Health Action Plan 2013-2020) (WHO, 2013), PVO Eiropas psihiskās veselības rīcības plānā 2013.-2020. gadam (angl. - The European Mental Health Action Plan 2013-2020) (WHO, 2015), EK Eiropas garīgās veselības un labklājības paktā (angl. - European Pact for Mental Health and Well-Being) (European Commision, 2008), š̄i pakta ietvara projektā izstrādātajās Eiropas psihiskās veselības un labklājības rīcības rekomendācijās (angl. - European Framework for Action on Mental Health and Wellbeing) (The European Union Joint Action for Mental Health and Wellbeing, 2016), kā arī Latvijas Sabiedrības veselības pamatnostādnēs 2014.-2020. gadam (LR Ministru kabinets, 2014).

Dati liecina, ka pašnāvības ir būtiska problēma bērnu un pusaudžu vidū Latvijā. Un tas savukārt norāda, ka ir nepieciešami uz pierādījumiem balstīti risinājumi, lai samazinātu cēloṇspecifisko mirstību no pašnāvībām bērnu un pusaudžu populācijā. Dati liecina, ka Latvijas iedzīvotāji 15-19 gadu vecuma grupā pēc mirstības no pašnāvībām ierindojas 7 . augstākajā vietā ES dalībvalstu vidū (Eurostat, 2018).

Būtisks pabeigtas pašnāvības riska faktors ir pašnāvnieciska uzvedība (angl. - suicidal behaviour) - domas par pašnāvību, pašnāvības mēǵinājumi u. c., kas iezīmē dažādas pakāpes 
risku pabeigtai pašnāvībai un bieži tiek izmantota asociēto riska faktoru pētniecībā (Bridge, Goldstein and Brent, 2006).

N̦emot vērā kognitīvos procesus, kas var novest līdz pabeigtai pašnāvībai (no domām līdz plānam, mēginājumam un pabeigtai pašnāvībai), jau domas par pašnāvību iezīmē pusaudžu riska grupu ar potenciālu šī kognitīvā procesa turpināšanai, kas var arī novest pie pašnāvības mēǵinājuma vai pabeigtas pašnāvības (Waldvogel, Rueter and Oberg, 2008).

Pusaudža psihoemocionālajai labklājībai izteikti nozīmīga ir gan ǵimenes un vienaudžu vide, kurā pusaudzis aug, attīstās un socializējas, gan individuālie psihoemocionālie un citi faktori, kas nosaka gan pusaudža attieksmi pašam pret sevi, gan sociālo funkcionēšanu.

Ģimene ir viena no divām pusaudža pamata dzīves vidēm, un negatīvie procesi ǵimenē var būt saistīti arī ar pusaudža pašnāvniecisko uzvedību. Ārvalstu pētîjumos, kuros tiek analizēti pašnāvnieciskās uzvedības riska un preventīvie faktori, bieži tiek analizēti arī ar ǵimeni saistīti aspekti. Neskatoties uz to, zināšanas par būtiskākajiem ar ğimeni saistītajiem riska un preventīvajiem faktoriem pašnāvnieciskajai uzvedībai joprojām ir pilnveidojamas (Randell et al., 2006).

Arī vienaudžu videi ir nozīmīga ietekme uz pusaudža psihisko un somatisko veselību. Pusaudži no emocionāli atbalstošas vienaudžu vides ir ar augstāku psihoemocionālo labklājību, šiem pusaudžiem ir augstāka sociālā kompetence, kā arī mazāk emocionālo un uzvedības problēmu (WHO, 2016; Kerr et al., 2003; Colaros and Eccles, 2003; Lenzi et al., 2012). Attiecīgi no otras puses - negatīvai pieredzei vai pat vardarbībai savstarpējās attiecībās var būt pretējs, negatīvs efekts uz pusaudža psihoemocionālo labklājību, piemēram, jebkura veida iesaiste ņirgāšanās procesā var būt saistīta ar pašnāvniecisku uzvedību (Holt et al., 2015).

Risku pusaudžu pašnāvnieciskajai uzvedībai var veidot arī individuālie psihoemocionālie faktori, piemēram, depresija un pašcieņa (Wild, Flisher and Lombard, 2004; Zubrick et al., 2017), atkarību izraisošo vielu lietošana un pazemināts veselības pašvērtējums (Kokkevi et al., 2012; Kang et al., 2015).

Īpaši aktuālu dažādu pašnāvnieciskās uzvedības riska faktoru potenciālās ietekmes analīzes nepieciešamību Latvijā padara augstais dažādu ar pašnāvniecisko uzvedību potenciāli saistīto faktoru izplatības līmenis Latvijas bērnu un pusaudžu populācijā, piemēram, vienaudžu vardarbība, emocionālā atbalsta trūkums (Pudule u. c., 2015; WHO, 2016), atkarību izraisošo vielu lietošana (Sniķere un Trapencieris, 2016) u. c.

Neskatoties uz augstajiem pašnāvību rādītājiem Latvijā un faktu, ka šobrīd jau aptuveni trešdaḷā pasaules valstu ar vidēju un augstu ienākumu līmeni ir izstrādātas un 
pieņemtas atsevišķas pašnāvību profilakses stratēǵijas (WHO, 2018b), Latvijā pašnāvnieciskās uzvedības un ar to saistīto riska faktoru pētniecība, jo īpaši bērnu un pusaudžu vidū, līdz šim vērtējama kā ierobežota un nepietiekama. Iespējams, tas ir viens no iemesliem, kādēl Latvijā iepriekš minētais politikas plānošanas dokuments nav ne izstrādāts, ne pieņemts. Uzteicams ir fakts, ka gan valsts iestādes, gan nevalstiskās organizācijas ir veikušas un veic atsevišḳas pašnāvību profilakses aktivitātes, tomēr, lai īstenotu uz pierādījumiem balstîtas pašnāvību un pašnāvnieciskās uzvedības profilakses programmas gan populācijā kopumā, gan riska grupās, pēc iespējas precīzākai intervenču definēšanai un mērḳēšanai caur padziḷinātu pētniecību ir nepieciešams iegūt uz pierādījumiem balstītas zināšanas specifiski par Latvijas pusaudžiem.

\section{Promocijas darba mērḳis}

Darba mērḳis ir izpētīt pašu ziņotās pašnāvnieciskās uzvedības izplatību un saistību ar gimenes un vienaudžu vidi raksturojošiem faktoriem, kā arī individuālajiem faktoriem 14-17 gadus vecu pusaudžu populācijā Latvijā.

\section{Promocijas darba uzdevumi}

1. Noskaidrot domu par pašnāvību un pašnāvības mēǵinājumu izplatību pusaudžu sociāldemogrāfiskajās grupās Latvijā.

2. Analizēt pusaudžu domu par pašnāvību un pašnāvības mēginājumu dzimumspecifisko saistību ar gimenes vidi raksturojošiem faktoriem - nedzīvošanu ar abiem bioloǵiskajiem vecākiem, emocionālā atbalsta trūkumu no vecākiem, pašnāvniecisku pieredzi ǵimenē, fizisku vardarbību ǵimenē un seksuālu uzmākšanos ǵimenē.

3. Analizēt pusaudžu domu par pašnāvību un pašnāvības mēgeinājumu dzimumspecifisko saistību ar vienaudžu vidi raksturojošiem faktoriem - emocionālā atbalsta trūkumu no vienaudžiem, pašnāvniecisku pieredzi vienaudžu vidū un vienaudžu ņirgāšanos skolā.

4. Analizēt pusaudžu domu par pašnāvību un pašnāvības mēǵginājumu dzimumspecifisko saistību ar individuālajiem faktoriem - depresijas simptomu līmeni, pašcieņas līmeni, veselības pašvērtējumu, riskantu alkohola lietošanu, ikdienas smēḳēšanu un narkotiku lietošanu. 
5. Sniegt promocijas darba secinājumos balstītas rekomendācijas intervencēm pašnāvnieciskās uzvedības profilaksei 14-17 gadus vecu pusaudžu populācijā Latvijā un nākotnē īstenojamai pētniecībai pusaudžu pašnāvnieciskās uzvedības jomā.

\section{Promocijas darba hipotēzes}

1. Abu dzimumu grupās pastāv saistība starp pusaudžu pašu ziņotajām domām par pašnāvību un visiem pētītajiem ar ǵimenes vidi saistītajiem, vienaudžu vidi raksturojošajiem un individuālajiem faktoriem.

2. Abu dzimumu grupās pastāv saistība starp pusaudžu pašu ziņotajiem pašnāvības mēǵinājumiem un visiem pētītajiem ar g̊imenes vidi saistītajiem, vienaudžu vidi raksturojošajiem un individuālajiem faktoriem. 


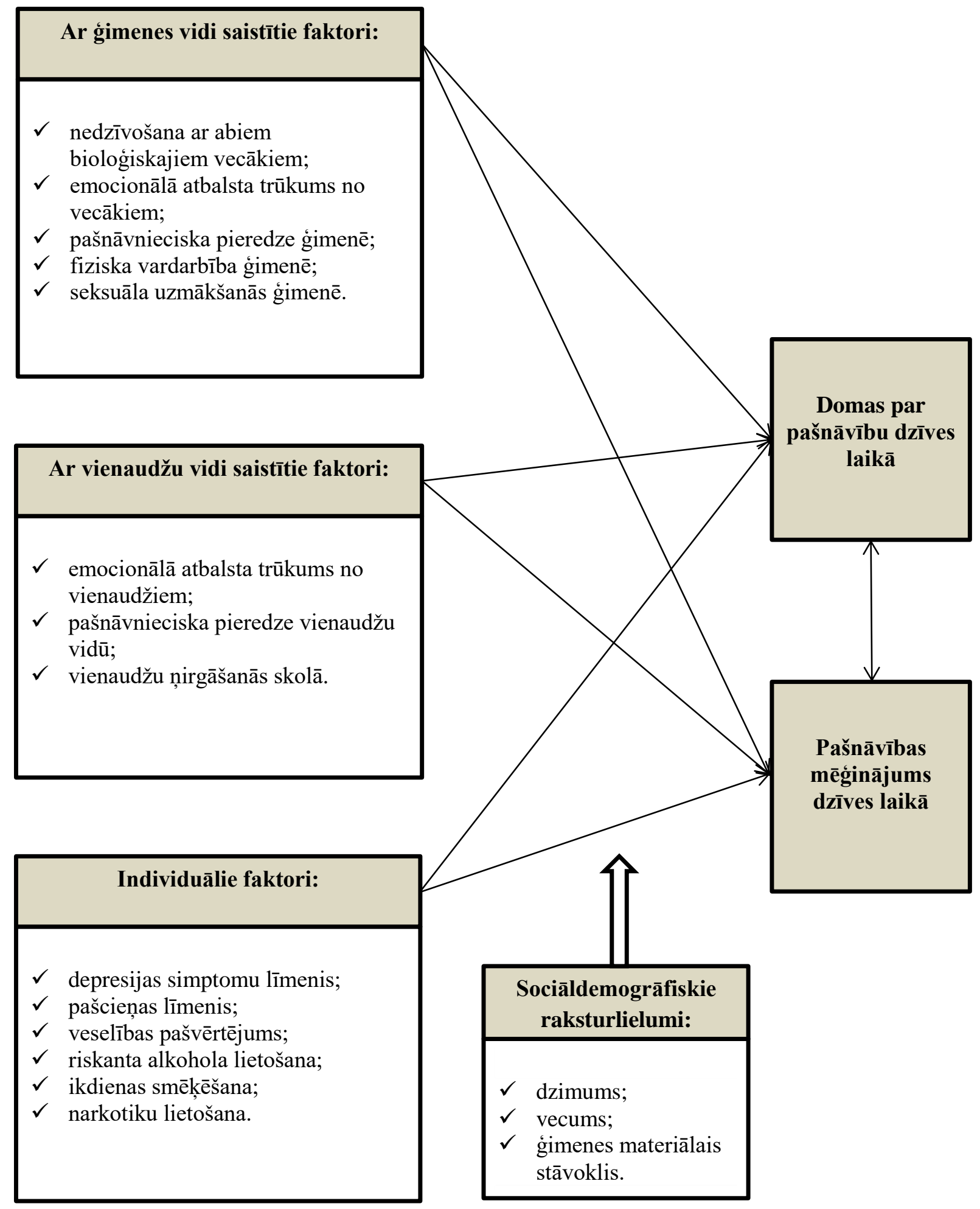

1.1. attēls. Promocijas darba pētniecības konceptuālais modelis 


\section{LITERATŪRAS APSKATS}

\subsection{Pašnāvnieciskās uzvedības jēdziens un problēmas aktualitāte pašnāvību kontekstā}

Pašnāvības bija un ir sabiedrības veselības problēma, kas cilvēkiem priekšlaicīgi atṇem dzīvību, dramatiski ietekmē pašnāvībās mirušo ǵimenes un līdzcilvēku dzīves, kā arī rada ekonomiskos zaudējumus valstīm kopumā (WHO, 2014a; Zhang, Tong and Zhou, 2005; Kinchin and Doran, 2018). Mirstība no pašnāvībām Eiropas reǵionā, salīdzinot ar citiem reǵioniem, ir augsta - deviṇas valstis ar augstāko mirstību no pašnāvībām pasaulē atrodas tieši šajā reǵionā (WHO, 2015).

Pašnāvību problēmas aktualitāte skaidri uzsvērta arī Latvijas Sabiedrības veselības pamatnostādnēs 2014.-2020. gadam, kuru virsmērḳis ir "palielināt Latvijas iedzīvotāju veselīgi nodzīvoto mūža gadu skaitu un novērst priekšlaicīgu nāvi, saglabājot, uzlabojot un atjaunojot veselību”. Šì galvenā sabiedrības veselības politikas plānošanas dokumenta 3.2.3. nodạ̣ā "Garīgā veselība" uzsvērts, ka "viena no būtiskākajām sabiedrības veselības problēmām Latvijā ir pašnāvības" un ka, "n,emot vērā augstos pašnāvību rādītājus, gan bērnu, gan pieaugušo pašnāvību un pašnāvnieciskās uzvedības profilakse jāuzskata par vienu no sabiedrības veselības prioritātēm Latvijā” (LR Ministru kabinets, 2014).

Iepriekš minētajā politikas plānošanas dokumentā uzsvērtā problēmas aktualitāte ir nenoliedzama - desmit gadu laikā, no 2007. līdz 2016. gadam, pašnāvībās Latvijā kopumā miruši 4330 cilvēki, t. i., pēdējos gados bijis vidēji viens pašnāvībā mirušais ik dienu, gandrīz uz pusi pārsniedzot transporta nelaimes gadījumos mirušo skaitu un pēc standartizētās mirstības rādīiājiem no pašnāvībām ierindojot Latviju otrajā augstākajā vietā ES dalībvalstu vidū, pirms Latvijas atstājot tikai kaimiņvalsti Lietuvu (Šica, Pulmanis un Taube, 2017; Baltāne u. c., 2017).

Viens no indikatoriem, kas plaši tiek izmantots gan nacionāla, gan starptautiska līmeṇa ziṇojumos, lai raksturotu priekšlaicīgu mirstību, ir potenciāli zaudētie mūža gadi jeb "gadi, kurus cilvēks būtu nodzīvojis līdz kādam noteiktam vecumam, ja nebūtu miris nelaimes gadījumā, kādas slimības vai cita iemesla dēḷ” (Skrule, 2014). Situācijas analīze liecina, ka Latvijā visvairāk potenciālo mūža gadu tiek zaudēts tieši ārējo nāves cēloṇu dēl, attiecīgi otrajā un trešajā vietā atstājot tādus nāves cēloṇus kā sirds un asinsvadu slimības un l̦aundabīgie audzēji. Savukārt starp ārējiem nāves cēloṇiem visvairāk potenciālo mūža gadu tiek zaudēts tieši pašnāvību dēḷ (Štāle, Treide un Rožkalne, 2016; Skrule, 2014).

66. Pasaules veselības asamblejā tika pieņemts PVO Psihiskās veselības rīcības plāns 2013.-2020. gadam (angl. - Mental Health Action Plan 2013-2020). Rīcības plāna situācijas 
aprakstā uzsvērts, ka pašnāvības ir otrais biežākais nāves cēlonis jaunu cilvēku vidū pasaulē. Tāpat norādīts, ka pašnāvību profilakse ir nozīmīga prioritāte un ka jauni cilvēki un gados vecāki cilvēki ir riska grupas domām par pašnāvību un paškaitējumam. N̦emot vērā ievērojamo skaitu pašnāvību riska faktoru, kas darbojas papildus psihiskiem traucējumiem, uzsvērta nepieciešamība intervences pašnāvību profilaksei īstenot ne tikai veselības sektora ietvaros, bet vienlaicīgi ar̄̄ caur citu sektoru iesaisti. Plāna globāli sasniedzamie mērḳi paredz līdz 2020. gadam samazināt mirstību no pašnāvībām par 10\% un panākt, ka $80 \%$ pasaules valstu ir vismaz divas funkcionējošas nacionāla līmeņa, starpsektoru sadarbībā balstītas psihiskās veselības veicināšanas un psihisko traucējumu un pašnāvību profilakses programmas. PVO pašnāvību profilaksei rekomendē izstrādāt un īstenot visaptverošas pašnāvību profilakses stratēǵijas, îpašu uzman̄̄bu veltot arī jauniešiem un citām mazāk aizsargātajām un paaugstināta pašnāvības riska grupām (WHO, 2013).

Arī PVO Eiropas psihiskās veselības rīcības plānā 2013.-2020. gadam (angl. - The European Mental Health Action Plan 2013-2020) uzsvērts, ka vairākās no Eiropas reğiona valstīm pašnāvība ir biežākais nāves cēlonis pusaudžu vidū. Šī plāna pirmais mērḳis nosaka, ka visiem ir līdzvērtīgas iespējas psihiskajai labklājībai visos vecumposmos, jo īpaši tiem, kas ir visievainojamākie vai ir riska grupās. Šñ mērķa sasniegšanai cita starpā valstīm rekomendēts izstrādāt un ieviest pašnāvību profilakses stratēgeijas, kas ietver pierādījumos balstītu pieeju, un apvieno aktivitātes populācijas līmen̄̄ ar risinājumiem mazāk aizsargātajām iedzīvotāju grupām (WHO, 2015).

Arī ES līmeņa politikas plānošanas dokumentos un rekomendācijās runāts par pašnāvību problemātiku un profilakses nozīmi. Jau 2008. gadā Briselē, ES augsta līmeņa konferencē "Kopā par garīgo veselību un labklājību" (angl. - Together for Mental Health and Wellbeing) tika pieṇemts Eiropas garīgās veselības un labklājības pakts (angl. - European Pact for Mental Health and Well-Being), kurā kā pirmā rīcības prioritāšu joma noteikta depresijas un pašnāvību profilakse. Dokumentā uzsvērts, ka ik pēc 9 minūtēm kāds ES iedzīvotājs mirst pašnāvībā, kā ar̄̄ fakts, ka pašnāvības mēǵinājumu skaits ir desmit reizes augstāks nekā pabeigtas pašnāvības. Dokumentā politiķi un ieinteresētās puses cita starpā tiek aicinātas veikt pasākumus, lai samazinātu pašnāvību riska faktorus (European Commision, 2008).

Pamatojoties uz Eiropas garīgās veselības un labklājības pakta ietvarā definētajām aktivitātēm, 2013.-2016. gadā 25 ES dalībvalstis (tajā skaitā Latvija), Islande un Norvēgija īstenoja Vienotas rīcības projektu garīgajā veselībā un labklājīīā (angl. - Joint Action for Mental Health and Wellbeing), kura galvenais mērḳis bija izveidot uz pierādījumiem balstītu ietvaru psihiskās veselības politikai Eiropas līmenī. N̦emot vērā Eiropas garīgās veselības un 
labklājības paktā noteiktos rīcības virzienus un problēmu aktualitāti, projektā starp četrām darba pakotnēm tika iekḷautas arī atsevišķas pakotnes depresijas un pašnāvību profilaksei un psihiskajai veselībai skolās. Projekta rezultātā izstrādātajā Eiropas psihiskās veselības un labklājības rīcības ietvarā (angl. - European Framework for Action on Mental Health and Wellbeing) kā viena no pamata rīcībām uzsvērta zināšanu un pierādījumu bāzes stiprināšana, kā arī dalīšanās ar labās prakses piemēriem starpvalstu līmenī (The European Union Joint Action for Mental Health and Wellbeing, 2016).

Politikas plānošanas dokumentu situācijas analīzēs ietvertā informācija un citi datu avoti liecina, ka pašnāvības un pašnāvnieciska uzvedība ir aktuāla problēma pusaudžu populācijā. Latvijas psihiskās veselības monitoringa dati liecina, ka laika posmā no 2007. līdz 2016. gadam Latvijā pašnāvībās miruši kopumā 115 bērni un jaunieši - 10 vecuma grupā 10 līdz 14 gadi un 105 vecuma grupā 15 līdz 19 gadi (Šica, Pulmanis un Taube, 2017).

Neskatoties uz faktu, ka pabeigtu pašnāvību skaits pusaudžu vecuma grupās ir zemāks nekā kopējā populācijā, pusaudžu vidū daudz izplatītāka ir tieši pašnāvnieciska uzvedība. Šī uzvedība, līdzīgi kā pabeigtas pašnāvības, ir izteikti multifaktoriālas izcelsmes fenomens, un tai ir ievērojams skaits dažāda veida cēloṇu. Šie cēloṇi jeb faktori, kas indivīdu pakḷauj riskam, ir komplicēti un var savstarpēji mijiedarboties, tādēḷ šo faktoru identificēšana un katra faktora lomas un ietekmes izpratne ir nozīmīgs jautājums pašnāvību profilaksē (Krug et al., 2002).

Zinātniskajā literatūrā nevalda vienprātība par pašnāvnieciskās uzvedības (angl. suicidal behavior) definīciju un ir vērojamas dažādas pieejas (Goodfellow, Kõlves and De Leo, 2018; De Leo et al., 2006; WHO, 2014b). Definīcijas izteikti variē, mēdz būt neprecīzas un mainīgas, jo īpaši, kad runa ir par pašnāvniecisku uzvedību bez letāla iznākuma un domām par pašnāvību.

Entonijs Spirito (Anthony Spirito) un Deidre Donaldsons (Deidre Donaldson) pusaudžu pašnāvniecisko uzvedību apraksta kā domas par pašnāvību un rīcību - pašnāvības mēǵinājumu, kas var notikt gan kā impulsīvs akts, gan kognitīvā procesa gaitā sekot pēc pasīvām domām par pašnāvību, nopietnas pašnāvības iespējas apsvēršanas un aktīvas pašnāvības plānošanas, kas var arī rezultēties pabeigtā pašnāvībā pat bez vēlmes mirt gadījumos, kad rīcība bijusi impulsīva un ar nāvējošām metodēm (Spirito and Donaldson, 1998). Arī vairākos citos zinātniskās literatūras avotos domas par pašnāvību tiek pieskaitītas pašnāvnieciskās uzvedības veidiem (Castle and Kreipe, 2007; Nock et al., 2008; Eskin, Palova and Krokavcova, 2014; Fedorowicz and Fombonne, 2007; Madu and Matla, 2004), kamēr tikai daḷā literatūras un pētījumu domas par pašnāvību un pašnāvnieciska uzvedība tiek savstarpēji konceptuāli nošķirtas (Silverman et al., 2007; WHO, 2002). Atsevišķos pētījumos 
vērojama vēl citādāka pieeja, piemēram, domas, plāni un mēǵinājumi kopā tiek definēti kā "ar pašnāvību saistîti iznākumi” (angl. - suicide related outcomes) (Borges et al., 2008).

Pašnāvības mēginājuma (angl. - suicide attempt) definīcijās zinātniskajā literatūrā ir vērojamas atšķirīgas nianses. Pašnāvības mēgeinājums tiek definēts gan kā neletāls, pašizraisīts destruktīvs akts ar skaidru vai netiešu nodomu mirt (Goldsmith et al., 2002), gan kā pašizraisīta, potenciāli kaitīga uzvedība ar neletālu iznākumu, par kuru ir tieši vai netieši pierādījumi par nodomu mirt (š̄ definīcija papildināta ar skaidrojumu, ka pašnāvības mēǵinājums var izraisīt vai arī neizraisīt ievainojumus vai nāvi - letālā gadījumā tā klasificējama kā pašnāvība. Tāpat norādīts, ka jebkuras pakāpes pašnāvnieciska nodoma gadījumā uzvedība uzskatāma par pašnāvības mēǵinājumu - neatkarīgi no ievainojumu pakāpes vai metodes letalitātes) (Silverman et al., 2007), gan kā potenciāli paškaitējoša uzvedība, kas saistīta ar vismaz nelielas pakāpēs nodomu š̄i akta rezultātā mirt (š̄ definīcija papildināta ar skaidrojumu, ka pašnāvības mēǵinājums var izraisīt vai arī neizraisīt reālus ievainojumus) (Posner et al., 2007; Crosby, Ortega and Melanson, 2011).

Pētījumu dati liecina, ka iepriekš izdarītam pašnāvības mēginājumam ir nozīmīga saikne ar pabeigtu pašnāvību un tas uzskatāms par visbūtiskāko pabeigtas pašnāvības riska faktoru (WHO, 2000; WHO, 2014a; Hawton et al. 1998).

Apvienotajā Karalistē veiktā pētījumā vecuma grupā 10-18 gadi savukārt noskaidrots, ka apzināta sevis savainošana, izdarot grieztas brūces, pat neatkarīgi no motivācijas un pašnāvnieciskā nodoma pakāpes, paaugstina gan šādas rīcības atkārtošanās, gan pabeigtas pašnāvības risku pētītajā astoṇu gadu periodā (Hawton et al., 2012).

Apzināta sevis savainošana un saindēšana ir ievērojami izplatītāka tieši bērnu un pusaudžu vidū - citā, Apvienotajā Karalistē veiktā pētījumā noskaidrots, ka kopējā populācijā šādas rīcības un pabeigtas pašnāvības pašnāvību relatīvo rādītāju attiecība ir $36,0: 1$, bet vecuma grupā 15-19 gadi - 148,3 : 1, savukārt vecuma grupā 10-14 gadi pat 498,8 : 1, ar salīdzinoši augstāku rādītāju meiteņu vidū (Hawton and Harris, 2008).

Savukārt 13 Eiropas valstīs par vecuma grupu 15-24 gadi veikta pētījuma rezultāti liecina, ka izdarīto pašnāvības mēginājumu un pabeigtu pašnāvību rādītāji starpvalstu līmenī korelē, ar izteiktāku korelāciju vīriešiem. Pētījuma rezultāti ir par pamatu hipotēzei, ka jaunu cilvēku (jo īpaši vīriešu) vidū arī nākotnē izmaiņas valstu pašnāvību mēǵinājumu relatīvajos rādītājos var ietekmēt pašnāvību relatīvos rādītājus (Hawton et al., 1998).

Ikgadējā psihiskās veselības monitoringa dati liecina, ka Latvijā pašnāvības mēǵinājumus ik gadu izdara ievērojams skaits bērnu un jauniešu: 2015. gadā tie bija 24 gadījumi vecuma grupā 10-14 gadi un 133 gadījumi vecuma grupā 15-19 gadi (Pulmanis, Japeniņa un Taube, 2016); 2014. gadā - 22 gadījumi vecuma grupā 10-14 gadi un 135 
gadījumi vecuma grupā 15-19 gadi (Pulmanis, Japeniņa un Taube, 2015), savukārt 2013. gadā 18 gadījumi vecuma grupā 10-14 gadi un 120 gadījumi vecuma grupā 15-19 gadi (Pulmanis, Pelne un Taube, 2014). Jāņem vērā, ka šie ir dati no Neatliekamās medicīniskās palīdzības dienesta par bērniem un jauniešiem, kuri mēǵinājuši izdarīt pašnāvību, bet izdzīvojuši pirmsslimnīcas neatliekamās palīdzības etapā, tātad - tikai par relatīvi smagākajiem gadījumiem, kuru gadījumā izsaukta neatliekamā medicīniskā palīdzība. Tāpat iezīmējas fakts, ka relatīvais pašnāvības mēǵinājumu skaits (uz 100000 attiecīgās vecuma grupas iedzīvotāju) ir augstāks jaunāku iedzīvotāju vidū, piemēram, 2015. gadā augstākais rādītājs $(152,8)$ bijis vecuma grupā 15-19 gadi (Pulmanis, Japeniṇa un Taube, 2016).

N̦emot vērā pašnāvnieciskās uzvedības saikni ar pabeigtām pašnāvībām un faktu, ka pabeigtas pašnāvības gadījumā ir grūti rekonstruēt miruša cilvēka nodomu un iemeslus, ja vien šis cilvēks pirms nāves nav izteicis nepārprotamas norādes vai atstājis pirmsnāves vēstuli (Krug et al., 2002), ar pašu ziṇotās pašnāvnieciskās uzvedības palīdzību pētniecībā bieži tiek analizēta arī asociēto riska faktoru ietekme. Bieži pašnāvnieciskās uzvedības izplatība un asociētie riska faktori tiek pētīti ar anketēšanas vai interviju palīdzību. Pētījuma dati liecina, ka anonīmās anketās pusaudži par pašnāvības mēǵinājumiem ziṇo 2-3 reizes biežāk nekā tiešajās intervijās (Safer, 1997), kas liecina, ka anonīmās aptaujās pusaudži ir atklātāki par šāda veida pieredzi.

Arī ar pašnāvniecisko uzvedību saistīto kognitīvo procesu definēšanai zinātniskajā literatūrā ir atrodamas dažādas pieejas. Viens no biežāk lietotajiem terminiem ir domas par pašnāvību (angl. - suicidal ideation), kuras var tikt definētas un klasificētas dažādi, piemēram, aktīvas domas par pašnāvību - domas par rīcību savas dzīves izbeigšanai, iekḷaujot metodes identificēšanu, plāna esamību un nodomu rīkoties, pasīvas domas par pašnāvību domas par nāvi, vēelēšanās būt mirušam, bez jebkāda plāna vai nodoma (Turecki and Brent, 2016). Domas par pašnāvību tiek definētas arī kā domas par vēlmi labāk būt mirušam vai kādā veidā nodarīt sev pāri (Hamdan et al., 2018; Johnson et al., 2002). Vēl viens termins, kas zinātniskajā literatūrā šajā kontekstā tiek izmantots, ir domas par paškaitējumu (angl. - self harm thoughts vai thoughts of self harm) (Kokkevi et al., 2012; Goodwin et al., 2013; Hibell et al., 2009), savukārt pats paškaitējums (angl. - deliberate self-harm) tiek definēts kā jebkāda veida paškaitējoša uzvedība, ieskaitot pašnāvības mēǵinājumus un nepašnāvniecisku sevis ievainošanu. Papildus sniegts skaidrojums, ka pašnāvības mēǵinājuma un nepašnāvnieciskas sevis ievainošanas apvienošana vienā kategorijā atspoguḷ to augsto komorbiditāti, kopīgos cēloṇus un faktu, ka nepašnāvnieciska sevis ievainošana ir spēcīgs prognostisks pašnāvības mēgininājuma riska faktors (Turecki and Brent, 2016). 


\subsection{Pusaudžu pašnāvnieciskās uzvedības kopējā izplatība un izplatība pusaudžu sociāldemogrāfiskajās grupās}

\subsubsection{Pašnāvības mēǵginājumi}

Dažādās valstīs veikto pētîjumu datu analīze liecina, ka pašnāvības mēǵinājumu izplatība pusaudžu vidū variē starp dažādām valstīm, atkarībā no pêtījuma metodoloǵijas un izmantotās pašnāvības mēǵinājuma definīcijas, kura, lai arī ir salīdzinoši precīzāka nekā domu par pašnāvību gadījumā, tomēr starp pētījumiem variē.

ASV veikts pētījumā, kurā analizēta pašnāvnieciskās uzvedības izplatība dzīves laikā, ar pašnāvniecisko uzvedību saistītie faktori un ārstēšanas iespējas 13-18 gadus vecu pusaudžu vidū (atlases brīdī 13-17 gadus veci, atsevišķi pusaudži palika 18 gadus veci līdz intervijas veikšanai). Tiešajās intervijās mājsaimniecībās tika aptaujāti 6483 pusaudži. Lai noskaidrotu pašnāvības mēginājumu izplatību dzīves laikā, tika analizētas apstiprinošās atbildes uz apgalvojumu par pusaudža mēginājumu sevi nogalināt. Pētījumā iegūtie rezultāti liecina, ka kopumā par šādu mēǵinājumu dzīves laikā atzīmējuši 4,1\% respondentu - 6,2\% meiteṇu un 2,1\% zēnu. Atšķirīibas starp dzimumiem uzskatāmas par statistiski nozīmīgām (Nock et al., 2013).

Citā ASV veiktā pētījumā analizēta pašnāvības mēǵinājumu izplatība 13-17 gadus vecu melnādaino pusaudžu populācijā. Arī šajā pētījumā pusaudži tika aptaujāti tiešajās intervijās. Pašnāvības mēginājuma noteikšanai tika izmantots jautājums par jebkad dzīves laikā veiktu mēginājumu izdarīt pašnāvību. Pētījuma rezultāti liecina, ka melnādaino pusaudžu populācijā par pašnāvībās mēǵinājumu ziņo 2,7\% respondentu - 3,9\% meiteņu un 1,5\% zēnu. Arī šajā pētījumā atšķirības starp dzimumiem uzskatāmas par statistiski nozīmīgām (Joe et al., 2009).

Identisks jautājums tiešajās intervijās uzdots arī pašnāvību mēǵinājuma mūža prevalences noskaidrošanai 3005 12-17 gadus vecu respondentu vidū Meksikā. Pētījumā noskaidrots, ka kopējā pašnāvības mēginājumu izplatība šajā vecuma grupā ir 4,3\% (Borges et al., 2008).

N̦emot vērā jau 1.1. nodaḷā pieminēto faktu, ka anonīmās anketās pusaudži par pašnāvības mēǵinājumiem ziṇo biežāk nekā tiešajās intervijās (Safer, 1997; Evans et al., 2005), arī pašnāvības mēginājumu izplatība šāda veida pētījumos ir augstāka.

17 Eiropas valstīs pēc vienotas metodoloǵijas veiktā pētījumā par 15-16 gadus veciem pusaudžiem anonīmā aptaujā kopumā piedalījās 45806 skolēni un pašnāvības mēginājumu izplatība noteikta pēc standartizēta jautājuma par mēǵinājumu izdarīt pašnāvību un šo 
mēginājumu skaitu. Pētījumā noskaidrots, ka vismaz viena pašnāvības mēǵinājuma dzīves laikā izplatîbas mediāna starp Eiropas valstīm, kuras piedalījās pētîjumā ir 10,5\%, ar zemāko izplatības rādītāju Armēnijā (4,1\%) un augstāko Ungārijā (23,5\%). Analizējot kopējos rādītājus dzimumu griezumā vērojams, ka meitenēm pašnāvības mēǵinājumu izplatības mediāna ir 13,7\%, bet zēniem - 6,9\%. Pētījumā uzdotais jautājums ḷauj secināt arī par atkārtotu pašnāvības mēginājumu izplatību. Iegūtie rezultāti liecina, ka atkārtotu (vairāk par vienu) pašnāvības mēǵinājumu mediānais izplatības rādītājs starp dalībvalstīm ir 4,8\% (6,4\% meitenēm un 3,3\% zēniem) (Kokkevi et al., 2012).

Iepriekš minētajā pētījumā par 15-16 gadus veciem pusaudžiem piedalìjās arī Grieķija, kur pašnāvības mēginājumu dz̄ives laikā atzīmēja 13,6\% skolēnu (Kokkevi et al., 2012). Izmantojot starptautiski standartizēto metodolog̣iju, Griekijā pusaudžu pašu zinoto pašnāvības mēǵinājumu prevalence tiek monitorēta jau kopš 1984. gada. Turklāt tiek apsekota paplašināta 14-18 gadus vecu pusaudžu kohorta. Pētîjuma dati liecina, ka laika posmā no 1984. līdz 2007. gadam pusaudžu pašu ziņoto pašnāvības mēǵinājumu izplatība ir būtiski pieaugusi: vecuma grupā 14-15 gadi tā palielinājusies no 5,9\% līdz 11,1\%; vecuma grupā 16 gadi - no 6,5\% līdz 12,1\% un vecuma grupā 17 gadi - no 7,7\% uz 14,4\% (Kokkevi et al., 2011).

Savukārt Norvēgijā veikta pētījuma viens no mērḳiem bija noskaidrot skolēnu pašu ziṇotā paškaitējuma un pašnāvības mēgeinājumu izplatību jaunāku pusaudžu (12-15 gadi) populācijā. Lai noteiktu pašnāvības mēǵinājumu izplatību, 2464 skolēnu lielajai, pētāmajai populācijai reprezentatīvajai atlasei tika uzdots jautājums par jebkad iepriekš veiktu mēginājumu sevi nogalināt, savukārt, lai iegūtu datus par paškaitējuma izplatību, tika uzdots jautājums par jebkad iepriekš veiktu tīšu pārdozēšanu vai darīšanu sev pāri jebkurā citā veidā. Pētījumā iegūtie dati liecina, ka šajā vecuma grupā pašnāvību dzīves laikā kopumā atzīmējuši 3\% skolēnu (4,2\% meiteṇu un 1,7\% zēnu), savukārt paškaitējumu gandrīz identisks skolēnu īpatsvars - 2,9\% (4,2\% meiteņu un 1,6\% zēnu) (Larsson and Sund, 2008).

Ķīnā savukārt veikta meta analīze par 43 šḳērsgriezuma pêtījumiem, kas veikti laika posmā no 2000. līdz 2014. gadam un kuros pētîta pašnāvības mēǵinājumu izplatība pusaudžu vidū Ķīnā. Noskaidrots, ka šajos 43 pētìjumos par kopumā 200124 respondentiem apvienotā (angl. - pooled) kopējā pašnāvības mēǵinājuma prevalence ir 2,94\% (95\% TI: 2.53\%-3,41\%) - 3,17\% (95\% TI: 2,56\%-3,91\%) meitenēm un 2,50\% (95\%TI: 2,08\%-3,01\%) zēniem. Kā pētījuma ierobežojums cita starpā norādīts kopējas pašnāvības mēǵinājuma definīcijas trūkums pētîjumos un atškirīības laika periodā, par kuru sniegta informācija (piemēram, iepriekšējie 6 mēneši, 12 mēneši, 2 gadi, dzīves laikā u. c.), taču, ņemot vērā meta analīzes 
ievērojamo apjomu, tajā iegūtie dati uzskatāmi par nozīmīgiem situācijas raksturošanai Ķīnā (Hu et al., 2015).

Arī Marokā veikts pētījums par pašnāvnieciskās uzvedības izplatību skolēnu vidū. Tika aptaujāti 3020 skolēni ar vidējo vecumu $16( \pm 2,1)$ gadi. Lai noteiktu pašnāvības mēǵinājumu izplatību dzīves laikā skolēniem tika uzdots jautājums par jebkad veiktu mēǵinājumu izdarīt pašnāvību. Iegūtie dati liecina, ka gan vecuma grupā 11-14 gadi, gan vecuma grupā 15-18 gadi pašnāvības mēginājumu izplatība ir samērā līdzīga - attiecīgi $10,8 \%$ un $10,9 \%$ (Zarrouq et al., 2015).

Pēc vienotas metodologijas 11 Eiropas valstīs veikts pētījums ar kopumā 12068 respondentiem - pusaudžiem ar vidējo vecumu 14,9 $( \pm 0,89)$ gadi, lai noskaidrotu tieši pašievainojošās uzvedības (angl. - direct self-injurious behavior) izplatību un saistību ar

psihosociālajiem faktoriem. Šīs uzvedības noteikšanai tika izmantoti seši anketas jautājumi par: a. plaukstas locītavas, rokas vai citu ḳermeṇa daḷu apzinātu graizīšanu vai tādu asu priekšmetu kā adatas, kniepadatas, skavas duršanu ādā (neieskaitot tetovējumus, ausu caurduršanu, adatas, kas tiek izmantotas narkotiku injicēšanai un ķermeņa pīrsingu); b. apzinātu sevis dedzināšanu ar cigareti, šķiltavām vai sērkociṇiem; c. apzinātu vārdu, attēlu vai citu marḳējumu izgriešanu uz savas ādas, vai apzinātu sevis saskrāpēšanu līdz rētām vai asiņošanai; d. apzinātu neḷaušanu rētām sadzīt vai košanu sev līdz ādas plīsumam; e. galvas dauzī̌sanu vai sevis sišanu, izraisot brūces; f. hospitalizāciju vai medicīniskas palīdzības saņemšanu dẹl kāda no iepriekš minētās uzvedības veidiem. Pētījuma rezultāti liecina, ka jebkāda veida pašievainojošu uzvedību dzīves laikā kopumā atzīmējuši 27,6\% respondentu (29,9\% meiteṇu un 24,6\% zēnu), savukārt atkārtotu (definēta kā iepriekš minētā uzvedība piecas vai vairāk reizes dz̄̄ves laikā) kopumā 7,83\% respondentu (8,65\% meiteņu un $6,80 \%$ zēnu). Lai arī kopējā izplatība meiteņu vidū ir augstāka, İrija un Rumānija bija vienīgās pētījumā iekḷautās valstis, kurās gan pašievainojošu uzvedību dzīves laikā, gan atkārtotu pašievainojošu uzvedību atzīmējuši lielāks īpatsvars zēnu, nekā meiteṇu (Brunner et al., 2014).

\subsubsection{Domas par pašnāvību}

Pētījumu datu analīze liecina, ka arī domu par pašnāvību un paškaitējumu izplatība pusaudžu vidū variē, atkarībā no valsts, kurā pētījums veikts, pētījuma metodologijas un izmantotās definīcijas, kuras starp pētījumiem variē.

Beḷgijāâ, Anglijāa, Ungārijāa, Īrijā, Nīderlandē, Norvēgijā un Austrālijā pēc vienotas metodologijas tika veikts pētījums, kopumā piedaloties 30477 skolēniem 14-17 gadu 
vecumā. Pêtījuma ietvaros tika veikta anonīma respondentu anketēšana, kurā cita starpā tika uzdots arī jautājums par domām par paškaitējumu. Paškaitējums pētījumā tika definēts kā uzvedība (piemēram, sevis griešana, lēkšana no augstuma), kura uzsākta, lai nodarītu sev pāri, medikamentu pārdozēšana, narkotiku lietošana kā rīcība, lai nodarītu sev pāri, kā arī uzturam neparedzētu vielu vai priekšmetu norīšana. Pētījumā iegūti rezultāti liecina, ka domas par paškaitējumu (bez izdarīta paškaitējuma) atzīmējuši kopumā 14,6\% respondentu - 20,3\% meiteņu un 9,2\% zēnu (Madge et al., 2011).

Jau 1.2.1. nodaḷā minētajā pētījumā par 15-16 gadus veciem pusaudžiem 17 Eiropas valstīs analizēta arī domu par paškaitējumu izplatība dzīves laikā, kura noteikta pēc starptautiski standartizēta jautājuma, kurā vaicāts, vai respondents ir domājis darīt sev pāri. Pētījumā noskaidrots, ka šādu domu izplatības mediāna kopā abiem dzimumiem ir 30,8\% 41,2\% meiteṇu un 20,2\% zēnu, savukārt biežas domas par paškaitējumu (piecas un vairāk reizes dzīves laikā) atzīmējuši kopumā 7,4\% respondentu - 10,4\% meitenu un 4,4\% zēnu (Kokkevi et al., 2012).

Savukārt Anglijā veiktā pētījumā analizēta 16-17 gadus vecu pusaudžu domu par pašnāvību izplatība. Ar pasta starpniecību izplatītajā anketā tika jautāts vai pusaudzis jebkad domājis par sevis nogalināšanu, pat ja to nedarītu. Kopumā pētījumā piedalījās 4810 respondenti un pētījuma rezultāti liecina, ka domas par pašnāvību kopumā atzīmējuši 15,8\% respondentu (Kidger et al., 2012).

Vjetnamā līdzīgs pētījums veikts pētījums 14-19 gadus jauniešu populācijā. Pētījums tika veikts divos posmos, no kuriem otrajā tika aptaujāti 6508 respondenti. Respondenti tika aptaujāti tiešajās intervijās, taču sensitīvie jautājumi (t. sk. jautājumi par pašnāvniecisko uzvedību) tika uzdoti ar respondentu pašu aizpildītas anketas palīdzību. Domu par pašnāvību izplatības noteikšanai tika izmantots jautājums par domām par pašnāvību dzīves laikā. Iegūtie rezultāti liecina, ka otrajā pētījumā šādas domas atzīmējuši 4,25\% jauniešu (Le et al., 2012).

Pašnāvnieciskās uzvedības izplatība pētīta arī Francijas pusaudžu un jaunu pieaugušo vidū. Ar anonīmas anketēšanas palīdzību mājsaimniecībās tika apsekota reprezentatīva 15-26 gadus vecu pusaudžu un jaunu pieaugušo kopa, domu par pašnāvību dzīves laikā noteikšanai izmantojot jautājumu par domu par pašnāvību reižu skaitu dzīves laikā ar iespēju atzīmēt " 0 " vai noteiktu domu par pašnāvību reižu skaitu. Pētîjuma rezultāti liecina, ka vecuma grupā 1516 domas par pašnāvību dzīves laikā atzīmējuši ievērojams īpatsvars - kopumā 42,5\% respondentu - 54,8\% meiteņu un 28,1\% zēnu (Fedorowicz and Fombonne, 2007).

Arī jau 1.2.1. nodaḷā minētajā ASV veiktajā pētījumā par 13-18 gadus veciem pusaudžiem analizēta domu par pašnāvību izplatība dzīves laikā. Izplatība aprēḳināta pēc respondentu apstiprinošajām atbildēm uz jautājumu par nopietnām domām par sevis 
nogalināšanu. Pētījumā iegūtie dati liecina, ka kopumā apstiprinoši atbildējuši 12,1\% respondentu - 15,3\% meiteṇu un 9,1\% zēnu (Nock et al., 2013).

Citā ASV veiktā pētījumā apsekoti 12-17 gadus veci pusaudži. Ar telefona interviju palīdzību domu par pašnāvību dzīves laikā noskaidrošanai tika uzdots jautājums vai pusaudzis jebkad ir juties tik slikti, ka ir domājis par pašnāvību. 2005. gada pētījuma posmā reprezentatīvu datu iegūšanai tika aptaujāti 3614 respondenti. Pētījuma rezultāti liecina, ka kopumā visā pētītajā vecuma grupā šādas domas atzīmējuši 10,9\% respondentu - 14,3\% meiteņu un 7,6\% zēnu, savukārt vecuma grupā 15-17 gadi - 19,2\% meiteņu un 11,3\% zēnu (Wolitzky-Taylor et al., 2010).

Savukārt Spānijā anonīmā anketēšanas ar datora palīdzību klasēs veikts 14-19 gadus vecu pusaudžu un jauniešu populācijai reprezentatīvs pētījums $(n=1664)$, kurā cita starpā uzdots arī jautājums domu par pašnāvību izplatības noteikšanai, kurā vaicāts par domām par pašnāvību dzīves laikā, pat ja pusaudzis to nekad nedarītu. Iegūtie dati liecina, ka kopumā domas par pašnāvību atzīmējuši 21,7\% respondentu - 18\% zēnu un 24,7\% meiteṇu. Papildus vērojama tendence domu par pašnāvību izplatībai pakāpeniski samazināties līdz ar vecuma palielināšanos - ja 14 gadu vecumā izplatība ir 26,8\%, tad 18-19 gadu vecumā 18,7\% (Fonseca-Pedrero et al., 2018).

Arī Latvijas kaimiņvalstīs Lietuvā un Igaunijā veikts pētījums, kurā cita starpā analizēta arī domu par pašnāvību izplatība pēdējā gada laikā. Ar standartizētas anketas un pētījuma metodoloǵijas palīdzību tika analizēta reprezentatīva kopa ar vidējo vecumu 15,7 gadi Lietuvā (respondentu skaits - 1 861) un 15,8 gadi Igaunijāa (respondentu skaits - 1 586). Domu par pašnāvību izplatības noskaidrošanai tika uzdots jautājums par nopietnām domām sevi nogalināt pēdējo 12 mēnešu laikā. Iegūtie rezultāti liecina, ka Lietuvā apstiprinoši uz šo jautājumu atbildējuši 18,3\% pusaudžu - 25,1\% meiteņu un 11,4\% zēnu, savukārt Igaunijā 13,9\% pusaudžu - 16,8\% meiteņu un 10,9\% zēnu (Mark et al., 2013).

\subsubsection{Pašnāvnieciskā uzvedība un gimenes materiālais stāvoklis}

Pētījumos apstiprināts fakts, ka bērniem un pusaudžiem no gímenēm ar zemu sociālekonomisko statusu biežāk tiek novēroti gan dažāda veida somatiskie simptomi, gan vērojams zemāks psihoemocionālās labklājības līmenis, gan pastāv augstāks risks citiem negatīvi ietekmējošiem apstākḷiem un faktoriem (Halldörsson et al., 2000; Sweeting and Hunt, 2014; McMunn et al., 2001).

Pētījumos analizēta arī pusaudža ǵimenes materiālā stāvokḷa saistība ar pašnāvniecisku uzvedību. 
Igaunijā veiktā pētījumā par 11, 13 un 15 gadus veciem skolēniem $(n=4389)$ noskaidrots, ka to 15 gadus veco skolēnu vidū, kuri nāk no ğimenēm ar zemu materiālās nodrošinātības līmeni, ir lielākas izredzes $(\mathrm{OR}=1,3)$ domām par pašnāvību, salīdzinot ar tiem pusaudžiem, kuru ǵimeṇu materiālās nodrošinātības līmenis ir augsts (Samm et al., 2010).

Austrālijā veiktā pētījuma par bērnu un pusaudžu garīgo veselību un labklājīibu ietvaros papildus analizēta arī bērnu un pusaudžu pašnāvnieciskās uzvedības saistība ar dažādiem respondenta ğimeni raksturojošiem faktoriem. Aptaujājot reprezentatīvu 12-17 gadus vecu bērnu un pusaudžu, un viņu vecāku respondentu atlasi (tika iekḷauti atsevišķi jautājumi gan bērniem un pusaudžiem, gan viṇu vecākiem) tika noskaidrots, ka tiem bērniem un pusaudžiem, kuri nāk no gimenēm ar zemāko ienākumu līmeni (pētījumā tas definēts kā mazāk par 52000 dolāriem gadā) ir vairāk nekā četras reizes lielākas izredzes $(\mathrm{OR}=4,1)$ būt mēginājušam izdarīt pašnāvību pēdējo 12 mēnešu laikā. Taču neapstiprinājās sakarība starp zemu ienākumu līmeni un domām par pašnāvību (Zubrick et al., 2016).

Savukārt jau iepriekš 1.2.1. un 1.2.2. nodaḷās aprakstītajā pētījumā par 15-16 gadus veciem pusaudžiem 17 Eiropas valstīs analizēta arī pašnāvnieciskās uzvedības saistība ar gimenes sociālekonomisko statusu, kas noteikts izmantojot pusaudža subjektīvo viedokli par savas gimenes materiālo labklājību salīdzinājumā ar citām ǵimenēm. Pētījumā iegūtie dati liecina, ka respondentiem, kuri savas ǵimenes materiālo stāvokli novērtēja kā zemu, ir augstākas izredzes gan biežām domām par paškaitējumu dz̄̄ves laikā $(\mathrm{OR}=2,6)$, gan pašnāvības mēǵinājumam dzives laikā $(\mathrm{OR}=2,0)$, salīdzinot ar tiem pusaudžiem, kuri ǵimenes materiālo labklājīîu novērtēja kā augstu (Kokkevi et al., 2012).

Skotijā veiktā pētījumā novērots, ka objektīvie ǵimenes sociālekonomiskā statusa rādītāji uzrāda vājas un pretrunīgas sakarības ar pusaudža psihologiiskajām ciešanām, bet šīs sakarības iezīmējas saistībā ar subjektīvajiem sociālekonomiskā statusa mērījumiem (Sweeting and Hunt, 2014), kas vedina domāt, ka pusaudža vecumā būtisks ir ne tikai ǵimenes sociālekonomiskais statuss "pats par sevi”, bet arī tas, kā pusaudzis šo statusu uztver mijiedarbībā ar sociālekonomisko vidi, kurā pusaudzis dzīvo.

Sakarības starp gimenes materiālo stāvokli un pusaudžu pašnāvniecisko uzvedību atklātas arī vairākos citos pētījumos (Liu et al., 2017; Fergusson, Woodward and Horwood, 2000; Park and Lee, 2016).

Vērojams, ka pašnāvnieciskās uzvedības sakarības ar ǵimenes materiālo labklājīibu zinātniskajā literatūrā skaidrotas dažādi un neviennozīmīgi - gan ar vecāku depresijas simptomiem ekonomiska spiediena rezultātā, kas var būt saistīi ar vecāku savstarpēji naidīgu un fiziski vardarbīgu uzvedību, kas savukārt var būt saistīta ar pusaudža pašcieņas trūkumu un depresiju, kas attiecīgi saistās ar pašnāvniecisku uzvedību (Yoder and Hoyt, 2005), gan ar 
ekonomisku apstākḷu radītu spiedienu, kas demoralizē vecākus, rada depresiju un konfliktus vecāku starpā, un reducē efektīvu bērna audzināšanu (Conger et al., 1992), gan ar atklāto faktu, ka kopienas līmen̄̄ mājsaimniecības nabadzība palielina iespēju mājsaimniecībai atrasties kopienā, kurā valda vispārēja nabadzība, attiecīgi palielinot risku pusaudzim sastapties ar citiem pašnāvnieciski noskaņotiem indivīdiem, kas atkal attiecīgi palielina iespēju pusaudzim asociēties ar šiem citiem un risku pašnāvnieciskai uzvedībai (Bernburg, Thorlindsson and Sigfusdottir, 2009). Iepriekš minētie fakti vedina domāt, ka ğimenes materiālais stāvoklis var būt kā jaucējfaktors attiecībā uz dažādu faktoru saistību ar pašnāvniecisku uzvedību, kas jāṇem vērā datu analīzes procesā.

\subsection{Pašnāvnieciskā uzvedība un ar gimenes vidi saistītie faktori}

Ģimene nodrošina vairākas nozīmīgas funkcijas g̊imenes iekšienē, piemēram, nodrošinot bērnu un jauniešu socializāciju un sagatavošanu pastāvīgai dzīvei, veicot ğimenes locekḷu aprūpi, kā arī sniedzot savstarpēju atbalstu gimenes locekḷu vidū. Tāpat arī spēcīgām, sociāli un ekonomiski neatkarīgām ǵimenēm ir būtiska, pozitīva ietekme uz sabiedrības un valsts labklājīibu kopumā (LR Ministru kabinets, 2011).

Savstarpēji atbalstošām attiecībām ir nozīmīga loma pusaudža attīstībā, socializācijā, veselībā un labklājīibā - piemēram, ciešas un savstarpēji atbalstošas attiecības ǵimenē ir saistītas ar labāku psihisko veselību (Rothon, Goodwin and Stansfeld, 2012), vecāku atbalsts var aizsargāt bērnu nelabvēlīgā, vardarbīgā vidē (Stadler et al., 2010; Wallen and Rubin, 1997), drošības un piederības sajūta var mazināt riska uzvedību (Brooks et al., 2012), kā arī noskaidrots, ka pusaudža piesaiste un pieķeršanās gimenei mazina pašnāvnieciskās uzvedības risku (Maimon, Browning and Brooks-Gunn, 2010).

Vecākiem ir galvenā loma kā "veselības aizsardzības aktīvam” sekmīgai pārejai no pusaudža uz jauna pieaugušā vecumu (WHO, 2016), savukārt destruktīvi ǵimenes modeḷi, negatīva bērnībā gūtā pieredze un traumatiski notikumi var būtiski negatīvi ietekmēt pusaudža dzīvi, jo īpaši, ja bērns vai pusaudzis nav spējis to pārdzīvot vai laikus saņemt atbalstu (Slimību profilakses un kontroles centrs [SPKC], 2016).

\subsubsection{Pašnāvnieciskā uzvedība un nedzīvošana ar abiem bioloğiskajiem vecākiem}

Vairāku pētījumu dati liecina, ka ǵimenes struktūrai var būt saistība ar bērnu un pusaudža emocionālo labklājīibu. Zviedrijā veikta pētījuma par ǵimenes struktūru un pusaudža emocionālo labklājību rezultāti liecina, ka salīdzinoši zemāks emocionālās labklājības līmenis 
novērojams tiem bērniem, kurus audzina tikai māte vai arī ğimenes, kurās tikai viens no bērna vecākiem ir biologiskais tēvs vai māte. Noskaidrots, ka sakarības ciešumu ietekmē arī vecākubērnu attiecību kvalitāte un finansiālā situācija tajās ǵimenēs, kur bērnu audzina tikai māte (Turunen, 2013).

Arī ASV veiktā pētījumā par ǵimenes struktūru un pusaudža somatisko veselību, uzvedību un emocionālo labklājību secināts, ka pētītie rādītāji ir labāki pusaudžiem, kuri ǵimenē dzīvo kopā ar abiem biologiskajiem vecākiem (Langton and Berger, 2011). Līdzīgas likumsakarības atklātas arī pētījumos par gados jaunākiem bērniem, proti, ka zemāka negatīvo uzvedības un emocionālo simptomu izplatība ir vērojama to bērnu vidū, kuri dzīvo ar abiem biolog̣iskajiem vecākiem (Luoma et al., 1999), tāpat noskaidrots, ka bērni no viena vecāka ǵimenēm un gímenēm, kurās tikai viens no bērna vecākiem ir bioloǵiskais tēvs vai māte, uzrāda zemākus rādītājus kognitīvajā un emocionālajā sfērā, salīdzinot ar bērniem no divu vecāku ğimenēm (Bali and Feng, 2003).

Ja ǵimenes struktūra ietekmē bērnu un pusaudžu psihoemocionālo labklājību, likumsakarīgi rodas jautājums par ǵimenes struktūras potenciālo sakarību ar pusaudžu pašnāvniecisko uzvedību, jo īpaši ņemot vērā faktu, ka starp 39 valstīm un reǵioniem, kas piedalījušies Skolēnu veselības paradumu pētījuma 2013./2014. gada posmā, Latvijā ir viens no zemākajiem skolēnu īpatsvariem, kuri dzīvo ǵimenē ar abiem vecākiem - 64,3\% (trešais zemākais rādītājs; zemākais rādītājs starp Baltijas valstīm) (WHO, 2016), turklāt šis îpatsvars kopš 1998. gada pētījuma posma ir sarucis par 14,8 procentpunktiem (1998. gadā - 79,1\%) (Pudule u. c., 2015).

Pētījumā par pašnāvnieciskās uzvedības izplatību un saistību ar gimenes faktoriem Lietuvas 13 un 15 gadus veco skolēnu populācijā tika anketēta populācijai reprezentatīva (n = 3572) skolēnu kopa. Pētījumā iegūtie dati liecina, ka skolēniem, kuri nedzīvo ǵimenēs ar abiem bioloǵiskajiem vecākiem ir 1,37 reizes lielākas izredzes būt nopietni apsvērušiem iespēju izdarīt pašnāvības mēǵinājumu, 1,42 reizes lielākas izredzes būt plānojušam pašnāvību un 1,63 reizes lielākas izredzes būt mēǵinājušam izdarīt pašnāvību, salīdzinot ar tiem skolēniem, kuri dzīvo gímenēs ar abiem biolog̣iskajiem vecākiem (Zaborskis, Sirvyte and Zemaitiene, 2016).

Līdzīgā pētījumā Igaunijā, kurā no pašnāvnieciskās uzvedības veidiem analizētas tikai domas par pašnāvību, apsekojot reprezentatīvu 11, 13 un 15 gadus vecu skolēnu atlasi ( $\mathrm{n}=$ 4 389), noskaidrots, ka dzīvošana viena vecāka ğimenē izredzes domām par pašnāvību palielina $(\mathrm{OR}=2,3)$ tikai 15 gadus vecām meitenēm, savukārt skolēniem, kuri dzīvo ǵimenēs, kurās tikai viens no bērna vecākiem ir bioloǵiskais tēvs vai māte un otrs - audžuvecāks, statistiski nozīmīgi lielākas izredzes domām par pašnāvību bija meitenēm visās pētītajās 
vecuma grupās $(\mathrm{OR}=1,6-2,1)$ un zēniem $11(\mathrm{OR}=1,9)$ un $13(\mathrm{OR}=3,4)$ gadu vecumā (Samm et al., 2010).

ASV veiktā pētījumā analizēta bērnībā sanemtās vecāku mīlestības apjoma un ǵimenes struktūras saistība ar domām par pašnāvību pieaugušo vecumā. Noskaidrots, ka neatkarīgi no tā vai respondenti dzīvoja, vai nedzīvoja ar abiem bioloǵiskajiem vecākiem līdz 16 gadu vecumam, respondentiem, kuri jutušies mīlēti no savu "aprūpētāju" puses, novērotas statistiski nozīmīgi 42\% - 43\% zemākas izredzes domām par pašnāvību, salīdzinot ar tiem respondentiem, kuri nav izjutuši savu "aprūpētāju" mīlestību. Attiecīgi secināts, ka saṇemtās mīlestības apjomam ǵimenē ir būtiskāka loma par gimenes struktūru (Susukida, Wilcox and Mendelson, 2016).

Savukārt pētījumā, kas veikts Somijas 13-18 gadus vecu skolēnu populācijā (n = 4 205), noskaidrots, ka skolēna dzīvošana gimenē, kurā abi vecāki dzīvo kopā, ir aizsargājošs faktors $(\mathrm{OR}=0,71)$ pret dzīves laikā izdarītu, apzinātu sevis savainošanu, izdarot grieztas brūces (Laukkanen et al., 2009).

Arī vairāku citu pētījumu dati liecina, ka pusaudža nedzīvošana ar abiem biologiiskajiem vecākiem paaugstina izredzes pašnāvnieciskai uzvedībai (Nock et al., 2013; Kokkevi et al., 2012; Kokkevi et al., 2011; Morey et al., 2008., Wagner, Cole and Schwartzman, 1995; Ponnet et al., 2005).

\subsubsection{Pašnāvnieciskā uzvedība un vecāku emocionālais atbalsts}

Pusaudžu pozitīvai mijiedarbībai ar vecākiem ir būtiska loma augšanas un attīstības procesā - pētījumu dati liecina gan par labas komunikācijas ar māti un tēvu pozitīvo ietekmi uz bērna apmierinātību ar dzīvi kopumā (Levin and Currie, 2010), gan vecāku-bērna emocionālās tuvības un vecāku izrādītās pieķeršanās saistību ar pozitīvu pusaudža pašvērtējumu (McAdams et al., 2017), gan vecāku-bērna savstarpējo attiecību kvalitātes saikni ar pusaudža agresijas līmeni (Fatima and Sheikh, 2016).

Iepriekš minētie fakti vedina domāt, ka neapmierinātībai attiecībās ar vecākiem un emocionālā atbalsta trūkumam ir iespējams pretējs efekts - t.sk. arī saistībā ar pašnāvnieciskas uzvedības biežāku izplatību starp tiem pusaudžiem, kuri pakḷauti negatīvi ietekmējošām savstarpējām attiecībām ar vecākiem, par ko liecina arī vairāku tālāk minēto pètījumu dati.

Ķ̄̄nā veikts pētījums ar 13512 respondentiem - skolēniem no 32 skolu 7 līdz 11 klasēm astoṇās Ķīnas pilsētās. Pētījumā analizēti dažādi gímenes faktori saistībā ar pusaudžu pašu ziṇotajiem pašnāvības mēginājumiem. Pētījumā cita starpā noskaidrots, ka starp 
pusaudžiem, kuri atzīmējuši vecāku rūpju trūkumu, pašnāvības mēǵinājumi ir statistiski nozīmīgi izplatītāki $(5,8 \%)$, nekā starp tiem pusaudžiem, kuri atzīmē, ka vecāki par viṇiem rūpējas $(1,8 \%)$. Tāpat pašnāvības mēginājumi bija statistiski nozīmīgi izplatītāki starp pusaudžiem, kuriem ir sliktas attiecības ar kādu no giimenes locekḷiem $(6,5 \% / 1,8 \%)$ un starp tiem, kuri piedzīvo konfliktus ar vecākiem $(4,1 \% / 1,9 \%)$. Pētījuma noslēgumā secināts, ka apsekojums ne tikai atklāj pašnāvības mēǵinājumus pusaudžu vidū kā būtisku sabiedrības veselības problēmu, bet arī apstiprina faktu, ka pusaudži no disfunkcionālām ǵimenēm pašnāvību mēǵina izdarīt biežāk, kas norāda uz nepieciešamību noteikt ar gímeni saistītos faktorus, novērtējot pašnāvības risku (Xing et al., 2010).

Jau iepriekš 1.3.1. nodạ̣ā minētajā Lietuvā veiktajā pētījumā analizēta arī pusaudžu pašnāvnieciskās uzvedības saistība ar dažādiem ǵimeni raksturojošiem faktoriem tieši to pusaudžu vidū, kuri dz̄ivo ar abiem biologiiskajiem vecākiem. Noskaidrots, ka pusaudžiem ar zemu apmierinātību attiecībās ǵimenē ir lielākas izredzes būt nopietni apsvērušiem pašnāvības izdarīšanu $(O R=2,03)$, plānojušiem pašnāvību $(O R=1,57)$ vai mēgeinājušiem pašnāvību izdarīt $(\mathrm{OR}=2,0)$, salīdzinot ar pusaudžiem, kuriem apmierinātība ar attiecībām ǵimenē ir augsta. Tāpat noskaidrots, ka pusaudžiem ar zemu tēva vai mātes emocionālo atbalstu ir lielākas izredzes būt nopietni apsvērušiem pašnāvības izdarīšanu $(O R=1,35$ tēvam; $O R=1,32$ mātei) vai mēǵinājušiem pašnāvību izdarīt $(O R=1,55$ tēvam; $O R=1,55$ mātei), attiecīgi salīdzinot ar pusaudžiem, kuru tēva vai mātes emocionālais atbalsts ir augsts (Zaborskis, Sirvyte and Zemaitiene, 2016).

Vācijas 9. klases skolēnu populācijai reprezentatīvā pētîjumā par audzināšanas stila saistību ar pusaudžu pašu ziņotajiem pašnāvības mēginājumiem tika anketēti 44610 respondenti. Pētījumā cita starpā noskaidrots, ka saņemta tēva $(\mathrm{OR}=0,830)$ un mātes $(\mathrm{OR}=0,810)$ emocionālā atsaucība bērn̄īāa (līdz 12 gadu sasniegšanai) ir protektīvs faktors pašnāvības mēg̣inājumiem vēlākā pusaudža vecumā (Donath et al., 2014).

Savukārt Igaunijā, Lietuvā un Luksemburgā veiktā pētījumā tika analizēti dati par kopumā 4954 skolēniem 15 gadu vecumā, lai noskaidrotu pusaudžu domu par pašnāvību saistību ar komunikāciju ar vecākiem. Pētījumā iegūtie rezultāti liecina, ka respondentiem, kuri atzīmējuši, ka viṇiem ir grūti vai ḷoti grūti runāt ar tēvu par lietām, kuras viṇus patiešām satrauc, ir lielākas izredzes (Igaunijā OR = 2,3; Lietuvā $\mathrm{OR}=2,0$; Luksemburgā $\mathrm{OR}=2,5$ ) domām par pašnāvību, salīdzinot ar skolēniem, kuri atzīmējuši, ka viṇiem ir viegli vai ḷoti viegli runāt ar tēvu par lietām, kuras viņus patiešām satrauc. Vēl būtiskāka ietekme atklāta komunikācijai ar māti - respondentiem, kuri atzīmējuši, ka viņiem ir grūti vai ḷoti grūti runāt ar māti par lietām, kuras viņus patiešām satrauc, izredzes domām par pašnāvību ir vēl augstākas (Igaunijā OR = 4,6; Lietuvā OR = 2,8; Luksemburgā = 3,4). Pêtījuma noslēgumā 
secināts, ka laba bērna komunikācija ar vecākiem ir nozīmīgs resurss domu par pašnāvību mazināšanai pusaudžu vidū (Mark et al., 2013).

Jau iepriekš 1.2.1. nodaḷā pieminētajā, pēc vienotas metodologijas 11 Eiropas valstīs veiktajā pētījumā papildus citiem faktoriem analizēta arī pašievainojošās uzvedības saistība ar attiecības ğimenē raksturojošiem faktoriem. Noskaidrots, ka lielākas izredzes šāda veida uzvedībai ir pusaudžiem, kuri atzīmējuši, ka vecāki neizprot viṇu problēmas $(O R=1,26$ 2,20, atkarībā no tā vai veikta vienfaktora vai daudzfaktoru samērošana) un pusaudžiem, kuri atzīmējuši, ka vecāki viņam nepievērš uzmanību $(\mathrm{OR}=1,30-2,11$, atkarībā no tā vai veikta vienfaktora, vai daudzfaktoru samērošana) (Brunner et al., 2014).

Arī attiecībā uz pusaudža iespējām saņemt emocionālu atbalstu ǵimenē situācija Latvijā nav vērtējama pozitīvi, proti, starp 39 valstīm un reǵioniem, kas piedalījušies Skolēnu veselības paradumu pētījuma 2013./2014. gada posmā, Latvijā ir salīdzinoši zems 15 gadus vecu skolēnu īpatsvars, kuri izjūt augstu gimenes emocionālo atbalstu - 54\% meiteņu un $55 \%$ zēnu, kas par 10 procentpunktiem meitenēm un 12 procentpunktiem zēniem atpaliek no vidējiem rādītājiem pētījuma dalībvalstīs (WHO, 2016).

Par problēmu liecina arī Valsts bērnu tiesības aizsardzības inspekcijas Bērnu un pusaudžu uzticības tālruņa konsultatīvo zvanu analīze, kur 2017. gadā attiecību problēmas ar vecākiem ir visbiežāk minētās starp visām attiecību problēmām. Šāda veida problēmas sarunās minētas 1546 gadījumos (Valsts bērnu tiesību aizsardzības inspekcija, 2018).

Abi iepriekš minētie fakti norāda uz būtisko nozīmi sakarību izpētei starp pašnāvniecisko uzvedību un vecāku emocionālo atbalstu.

\subsubsection{Pašnāvnieciskā uzvedība un pašnāvnieciska pieredze ğimenē}

Zaudējums rada emocionālas ciešanas un var radīt ilgstošu nespēju samierināties ar notikušo. Komplicēta rakstura sēras un pašnāvnieciska uzvedība biežāk sastopama gadījumos, kad nāve bijusi vardarbīga, piemēram, pašnāvības gadījumā (Turecki and Brent, 2016).

Zviedrijas vispārējai populācijai reprezentatīva, uz reğistru datiem balstīta, 51 gadu ilga pētījuma dati par 11,4 miljoniem unikālo indivīdu un 83951 pašnāvības upuri liecina, ka pabeigtas pašnāvības risku palielina pašnāvība radinieku vidū un šo ǵimenes pašnāvību "klāstera efektu" ietekmē gan ǵenētiskie, gan vides faktori. Pētījumā rekomendēts noskaidrot pašnāvības pieredzes esamību gimenes vēsturē gan novērtējot pašnāvības risku klīniskos apstākḷos, gan izstrādājot un īstenojot pašnāvību profilakses pasākumus (Tidemalm et al., 2011). Atklātie fakti populācijas līmen̄̄ vedina domāt arī par sakarību starp piedzīvotu pašnāvību vai pašnāvības mēginājumu gímenē un pusaudža pašnāvniecisko uzvedību. 
Nīderlandē un Slovēnijā veikta pêtījuma dati par 19250 Nīderlandes un 4706 Slovēnijas vidusskolas skolēniem ar vidējo vecumu 16,4 gadi dati liecina, ka skolēniem, kuri aptaujas anketās atzīmējuši pašnāvības mēǵinājumu ǵimenes locekḷu vidū, pašnāvību ǵimenes locekḷu vidū vai brāḷa/māsas nāvi, novērojamas lielākas izredzes gan pašnāvības mēg̣inājumam dz̄ives laikā (OR = 2,5 saistībā ar pašnāvības mēginājumu gimenes locekḷu vidū, $\mathrm{OR}=2,5$ saistībā ar pašnāvību ǵimenes locekḷu vidū, OR = 1,8 saistībā ar brāḷa/māsas nāvi), gan domām par pašnāvību ( $\mathrm{OR}=2,3$ saistībā ar pašnāvības mēǵinājumu gimenes locekḷu vidū, $\mathrm{OR}=2,1$ saistībā ar pašnāvību ǵimenes locekḷu vidū, OR = 1,5 saistībā ar brāḷ/māsas nāvi) (Tomori et al., 2001).

Savukārt Meksikā veikts pētījums, lai noskaidrotu emocionāli traumatisku notikumu saistību ar “ar pašnāvību saistītiem iznākumiem”, kas ietver domas par pašnāvību, pašnāvības plānus un pašnāvības mēginājumus 12-17 gadus vecu bērnu un pusaudžu populācijā. Iegūtie dati par 3005 respondentiem liecina, ka tiem respondentiem, kuri pieredzējuši negaidītu tuvinieka nāvi vai citu traumatisku notikumu ar tuvinieku, ir lielākas izredzes domām par pašnāvību $(\mathrm{OR}=1,6)$, pašnāvības plānam $(\mathrm{OR}=2,0)$ un pašnāvības mēǵinājumam $(\mathrm{OR}=$ 2,1), salīdzinot ar tiem respondentiem, kuri šādus potenciāli traumatiskus notikumus nav piedzīvojuši (Borges et al., 2008).

Nīderlandē un Beḷgijāā tika veikts pētījums, lai noskaidrotu paškaitējuma izplatību un riska faktorus 15-16 gadus vecu pusaudžu vidū. Ar anonīmas anketēšanas palīdzību tika aptaujāts 4431 skolēns Beḷgijā un 4458 skolēni Nīderlandē. Pētījumā noskaidrots, ka tiem skolēniem, kuru gimenes locekḷu vidū kāds pēdējā gada laikā izdarījis pašnāvības mēǵinājumu, ir gandrīz četras reizes lielākas izredzes $(\mathrm{OR}=3,91)$ izdarītam paškaitējumam pēdējā gada laikā, salīdzinot ar tiem skolēniem, kuri pašnāvības mēǵinājumu ǵimenes locekḷu vidū pēdējā gada laikā nav piedzīvojuši (Portzky, De Wilde and van Heeringen, 2008).

Augstāks risks pašnāvnieciskai uzvedībai to pusaudžu vidū, kuri bijuši pašnāvnieciskas uzvedības vai pašnāvības gimenē liecinieki, atklāts un analizēts arī vairākos citos zinātniskos pētījumos (Carel and Roberts, 2005; Brent and Mann, 2006; Chan et al., 2018; Nanayakkara et al., 2013).

\subsubsection{Pašnāvnieciskā uzvedība un vardarbība ğimenē}

Vecāku vai citu aprūpētāju vardarbība pret bērnu ir nozīmīga sabiedrības veselības un sociālās labklājīibas problēma ne tikai attīstības valstīs, bet arī valstīs ar augstiem ienākumiem. Šì vardarbība ir izplatīta un var izraisīt nopietnus ievainojumus, nāvi vai citas ilgtermiņa sekas, kas var ietekmēt cilvēka dzīvi arī pieaugušā vecumā, viṇa nākamo ǵimeni un 
sabiedrību kopumā. Dati liecina, ka ik gadu 3,7\% -16,3\% bērnu piedzīvo fizisku vardarbību, $15 \%$ - 30\% meiteṇu un 5\% - 15\% zēnu piedzīvo seksuālu vardarbību, bet 1,4\%-15,4\% tiek atstāti novārtā (Gilbert et al., 2009).

21 pasaules valstī veikta pētījuma ar 55299 respondentiem rezultāti liecina, ka bērnībā gūta nelabvēlīgā pieredze saistīta ar pašnāvniecisku uzvedību tālākās dzīves laikā, turklāt fiziska un seksuāla vardarbība atklāta kā riska faktors ar visbūtiskāko ietekmi gan uz pašnāvnieciskās uzvedības sākšanos, gan atkārtošanos un tās nozīme nesamazinājās arī pēc samērošanas ar respondenta psihiskās veselības statusu. Savukārt respondentiem, kuri piedzīvojuši fizisku vardarbību, novērotas 2,1 līdz 2,7 reizes lielākas izredzes domām par pašnāvību un 2,4 līdz 3,7 reizes lielākas izredzes pašnāvības mēǵinājumam, salīdzinot ar tiem respondentiem, kuri fizisku vardarbību nav piedzīvojuši. Attiecībā uz piedzīvotu seksuālu vardarbību šīs izredzes ir vēl augstākas - 2,5 līdz 3,4 domām par pašnāvību un 3,8 līdz 5,7 pašnāvības mēǵinājumam (Bruffaerts et al., 2010).

Līdzīgas sakarības iezīmējas arī pētījumā, kas veikts psihosomatiskas klīnikas pacientu vidū Vācijā - arī šo respondentu vidū kā būtiskākie no pētītajiem riska faktori pašnāvības mēginājumam atklāti fiziska sodīšana $(R R=3,2)$ un seksuāla vardarbība $(R R=3,5)$ (Herdt et al., 2008), savukārt Nīderlandes populācijā veiktā pētījumā statistiski lielākas izredzes gan domām par pašnāvību, gan pašnāvības mēǵinājumam novērotas pētījuma dalībniekiem, kuri bērnībā pieredzējuši fizisku vardarbību un atstāšanu novārtā, bet sakarības ar seksuālu vardarbību nav izrādījušās statistiski nozīmīgas (Enns et al., 2006).

Latvijas jauniešu vidū veiktā pētījumā secināts, ka bērnībā pieredzēta vardarbība (fiziska, emocionāla, fiziska nevērība, emocionāla nevērība), izņemot seksuālo vardarbību, saistīta ar 2,2 līdz 4,0 reizes lielākām izredzēm pašnāvības mēǵinājumam jauniešu vecumā, salīdzinot ar respondentiem bez vardarbības pieredzes, samērojot gan ar respondenta dzimumu, gan ğimeni raksturojošajiem faktoriem (Springge, 2017).

Iepriekš minētajos pētījumos analizēta bērnības nelabvēlīgās pieredzes ietekme no jaunieša vai pieaugušā perspektīvas. Mazāk ir pētīta vardarbības gimenē ietekme no pusaudžu perspektīvas un vardarbības ğimenē liecinieka statusa saistība ar pašnāvniecisko uzvedību.

ASV veiktā pētījumā par 4023 12-17 gadus veciem pusaudžiem ar telefona interviju starpniecību noskaidrots, ka tiem respondentiem, kuri piedzīvojuši fizisku vai seksuālu vardarbību no jebkuras citas personas, vai bijuši vardarbības liecinieki, ir lielākas izredzes gan domām par pašnāvību dzīves laikā (OR = 1,89 fiziskai vardarbībai; OR = 1,69 seksuālai vardarbībai; $\mathrm{OR}=1,28$ vardarbības lieciniekiem), gan pašnāvības mēginājumiem $(\mathrm{OR}=1,72$ fiziskai vardarbībai; OR = 2,09 seksuālai vardarbībai; vardarbības lieciniekiem sakarība nav statistiski nozīmīga), salīdzinot ar respondentiem, kuri vardarbību nav piedzīvojuši (Waldrop 
et al., 2007). Savukārt citā ASV veiktā pētījumā, kurā apsekoti 10-17 gadus veci bērni un pusaudži, neapstiprinājās sakarība starp vardarbības liecinieka gimenē statusu un domām par pašnāvību (Turner et al., 2012).

Austrālijā veiktā pētîjumā par 2485 skolēniem ar vidējo vecumu 14 gadi no 27 skolām Austrālijas dienvidu dạ̦ā noskaidrots, ka zēnu vidū seksuāla vardarbība no jebkuras citas personas ir statistiski nozīmīgi un neatkarīgi saistīta ar domām par pašnāvību $(O R=5,0)$ pašnāvības plāniem $(\mathrm{OR}=10,6)$, pašnāvības draudiem $(\mathrm{OR}=10,9)$, paškaitējumu $(\mathrm{OR}=4,3)$ un pašnāvības mēǵinājumu (OR = 15,0) pat pēc samērošanas ar depresiju, bezcerības līmeni un ǵimenes disfunkciju, tomēr meitenu vidū sakarība starp seksuālu vardarbību un pašnāvniecisku uzvedību pilnībā izzuda pēc samērošanas ar depresiju, bezpalīdzību un ǵimenes disfunkciju (Martin et al., 2004).

Savukārt Somijā veiktā pētījumā par 508 12-17 gadus veciem pusaudžiem, kuriem bijusi nepieciešama stacionēšana psihisku traucējumu dēḷ, analizēta pašnāvnieciskās uzvedības saistība ar dažāda veida nelabvēlīgu pieredzi. Pētījumā ne starp zēniem, ne meitenēm netika atrasta statistiski nozīmīga saistība starp pašnāvības mēgeinājumiem un vardarbības liecinieka statusu mājās, kā arī starp pašnāvības mēǵinājumiem un fizisku vardarbību no vecākiem, taču iegūtie rezultāti liecināja par vairāk nekā divas reizes (OR = 2,28) lielākām pašnāvības mēǵinājuma izredzēm piedzīvotas seksuālas vardarbības gadījumā meiteņu vidū (Isohookana et al., 2013).

Ķīnā veikts pêtījums 75715 desmito līdz divpadsmito klašu skolēnu vidū, lai noskaidrotu sliktas izturēšanās pret bērnu saistību ar pašnāvības mēgeinājumu un atkārtotiem pašnāvības mēginājumiem. Pētījumā noskaidrots, ka lielākas izredzes gan vienam, gan vairākiem pašnāvības mēǵinājumiem pēdējo 12 mēnešu laikā ir skolēniem, kuri gímenē piedzīvojuši fizisku, emocionālu vai seksuālu vardarbību vai fiziski, vai emocionāli atstāti novārtā. Augstākas izredžu attiecības novērotas tieši sakarībai ar atkārtotiem pašnāvības mēg̊inājumiem (Guo et al., 2018).

Pieredzētās vardarbības sakarības ar pašnāvības mēǵinājumiem novērotas arī Kanādas “ielu jauniešu” vidū (Hadland et al., 2015) un citos pētījumos (Brown et al., 1999; Fergusson, Woodward and Horwood, 2000).

Arī sakarību izpēti starp vardarbību g̊imenē raksturojošiem faktoriem un pašnāvniecisku uzvedību vēl būtiskāku padara ievērojamais bērnu un pusaudžu īpatsvars, kuri vardarbībai ir pakḷauti - Latvijā veikta pētījuma dati liecina, ka 16,4\% jauniešu pirms 18 gadu sasniegšanas cietuši no fiziskas vardarbību no saviem vecākiem vai kāda cita pieaugušā mājās, bet katrs desmitais (10,3\%) piedzīvojis seksuālu vardarbību (Velika u. c., 2012). 


\subsection{Pašnāvnieciskā uzvedība un ar vienaudžu vidi saistītie faktori}

Līdz ar pusaudža vecuma palielināšanos pieaug arī vienaudžu vides nozīme sekmīgā pusaudža attīstībā. Lai arī vecāki joprojām ir bērnam kā "drošības bāze”, pusaudzis arvien vairāk laika pavada vienaudžu vidū, tiecas meklēt tajā draudzību, pieķeršanos un drošu patvērumu, jo īpaši gadījumos kad attiecības ar vecākiem nesniedz nepieciešamo drošības sajūtu (Lieberman, Doyle and Markiewicz, 1999). Draugiem ir būtiska nozīme arī pusaudža vispārējās emocionālās labklājības, pašapziņas, pielāgošanās spēju (Traylor et al., 2016) un pašcieņas vairošanā, kā arī depresijas simptomu mazināšanā (Colarossi and Eccles, 2003). Vienaudžu grupas pusaudzim var būt atbalsta un savstarpējas pieṇemšanas avots, bet "monētas otra puse" ir fakts, ka vienaudži var būt arī emocionālu ciešanu un sociāla spiediena avots, jo pašapziņa un sevis pieņemšana pusaudžu vecumā bieži ir atkarīga no tā vai pusaudzis tiek pieņemts vienaudžu grupās, jo īpaši tajās, kurās pēc pusaudžu domām ir augsts “sociālais prestižs" (Wagner, 2009). Ar̄̄ spēja izveidot tuvu draudzību kḷūst izteikti aktuāla tieši pusaudža vecumā, salīdzinot ar bērniem jaunākās vecuma grupās (Buhrmester, 1990). Iepriekš minētie fakti apliecina vienaudžu vides būtisko nozīmi pusaudža psihoemocionālajai labklājībai - attiecīgi dažāda veida vienaudžu atbalsta vides disfunkcija un citi ar vienaudžu vidi saistīti negatīvi faktori var saistīties arī ar pusaudžu pašnāvniecisko uzvedību - tālākajās nodaḷās analizēti pētîjumu dati par sakarībām starp pusaudžu pašnāvniecisko uzvedību un dažādiem, ar vienaudžu vidi saistītiem faktoriem.

\subsubsection{Pašnāvnieciskā uzvedība un vienaudžu emocionālais atbalsts}

Dienvidkorejā veiktā šḳērsgriezuma pētījumā analizēta paškaitējuma izplatība un sakarības ar virkni potenciāli ietekmējošo faktoru pusaudžu ar vidējo vecumu 14,38 gadi vidū (n = 784). Pētījumā noskaidrots, ka sliktas attiecības ar vienaudžiem statistiski nozīmīgi palielina risku paškaitējumam, turklāt pētījuma diskusijas dạ̄ā uzsvērts, ka pētniekiem negaidīts bijis atklātais fakts, ka sliktām attiecībām ar vienaudžiem ir būtiskāka ietekme uz pašu ziņoto paškaitējumu nekā zemai pusaudža piesaistei gimenei. Secināts, ka vienaudžu savstarpējo attiecību uzlabošanai pētītajā vecumposmā var būt nozīmīga loma paškaitējuma profilaksē (Lee, 2016).

Līdzịgā vecuma grupā (vidējais vecums: 14,9) jau 1.2.1. un 1.3.2. nodaḷā pieminētajā pētījumā analizētas arī pusaudžu tieši pašievainojošās uzvedības sakarības ar dažādiem psihosociāliem faktoriem 11 Eiropas valstīs. Noskaidrots, ka pusaudžiem, kuri izjūt vientulību un problēmas savstarpējās attiecībās, pat pēc samērošanas ar citiem potenciāli 
ietekmējošajiem faktoriem ir statistiski nozīmīgi lielākas izredzes atkārtotai pašievainojošai uzvedībai $(\mathrm{OR}=1,39)$, salīdzinot ar pusaudžiem, kuri vientulību un problēmas savstarpējās attiecībās nav izjutuši (Brunner et al., 2014).

Savukārt ASV veikts pētījums par pašnāvnieciskās uzvedības saistību ar attiecībām ar vecākiem, vienaudžiem un skolotājiem raksturojošiem faktoriem ASV Latīṇamerikas izcelsmes pusaudžu vidū ar vidējo vecumu 15 gadi $(n=1618)$. Pētījumā netika atrastas sakarības ne starp problēmām attiecībās ar vienaudžiem un domām par pašnāvību, ne problēmām attiecībās ar vienaudžiem un pašnāvības mēǵinājumiem (De Luca, Wyman and Warren, 2012).

Arī dati par pusaudža iespējām saņemt vienaudžu atbalstu iezīmē negatīvu ainu nacionālā kontekstā, proti, starp 39 valstīm un reǵioniem, kas piedalījušies Skolēnu veselības paradumu pētījuma 2013./2014. gada posmā, Latvijā ir trešais zemākais 15 gadus vecu skolēnu īpatsvars, kuri izjūt izteiktu vienaudžu atbalstu - tikai 51\% meiteņu un 42\% zēnu, kas par 17 procentpunktiem meitenēm un 14 procentpunktiem zēniem atpaliek no vidējiem rādītājiem pētîjuma dalībvalstīs (WHO, 2016).

\subsubsection{Pašnāvnieciskā uzvedība un pašnāvnieciska pieredze vienaudžu vidū}

Pēkšņai un negaidītai vienaudža nāvei var būt būtiska negatīva ietekme, kas palielina risku plaša spektra negatīvām fiziskām, emocionālām, sociālām un kognitīvām konsekvencēm (Malone, 2007).

ASV veiktā šķērsgriezuma pētījumā piedalījās 13465 pusaudži no 7.-12. klasēm ar vidējo vecumu 15,8 gadi un dati tika apkopoti gan veicot anketēšanu klasēs, gan pēc tam daḷēji strukturētās intervijas pusaudža dzīvesvietā. Lai samazinātu intervētāju un vecāku potenciālo ietekmi uz sniegtajām atbildēm, tika izmantota automātiskā, datorizētā intervēšanas sistēma, kurā pusaudzis sensitīvos intervijas jautājumus klausās austiṇās un atzīmē klēpjdatorā. Pētījumā noskaidrots, ka tiem pusaudžiem, kuriem kāds no draugiem ir mēǵinājis izdarīt pašnāvību pēdējo 12 mēnešu laikā, ir lielākas izredzes arī domām par pašnāvību pēdējo 12 mēnešu laikā ( $O R=2,72$ zēniem; $O R=2,37$ meitenēm) un pašnāvības mēgéninājumam tādā pašā laika periodā ( $O R=1,71$ zēniem; $O R=1,66$ meitenēm), salīdzinot ar respondentiem, kuri nav piedzīvojuši pašnāvības mēginājumu starp draugiem (Bearman and Moody, 2004).

Iepriekš minētajam pētījumam izmantoti periodiska pusaudžu veselības apsekojuma dati. No vēlāka š̄ pētījuma posma datu bāzes cita pētījuma veikšanai atlasīti dati par 4719 respondentiem ar vidējo vecumu 16,7 gadi, lai cita starpā analizētu arī sakarību starp 
pieredzētu pabeigtu pašnāvību un pašnāvības mēǵinājumu draugu vidū un paša pusaudža pašnāvības mēǵinājumu. Pētîjumā iegūtie dati liecina, ka pusaudžiem, kuri pēdējo 12 mēnešu laikā pieredzējuši vienaudža pašnāvību, ir lielāks risks ( $R R=3,69$ pusaudžiem ar depresiju; $\mathrm{RR}=$ 4,07 pusaudžiem bez depresijas) pašnāvības mēǵinājumam pēdējo 12 mēnešu laikā, salīdzinot ar pusaudžiem, kuri drauga pašnāvību pēdējā gada laikā nav pieredzējuši. Papildus šajā pētījumā noskaidrots, ka pieredzēta drauga vai ǵimenes locekḷa pašnāvība vai pašnāvības mēǵinājums būtiski palielina pusaudža pašnāvības mēg̣inājuma risku, neatkarīgi no depresijas līmeņa. Pētījuma noslēgumā secināts, ka gan pieredzēta drauga, gan gímenes locekḷa pašnāvība vai pašnāvības mēǵinājums saistīts ar pusaudža pašnāvības mēǵinājuma riska līmeni, kas ir ekvavilents depresijas radītajam riskam (Nanayakkara et al., 2013).

Ķīnā veiktā šķērsgriezuma pētījumā analizēti psihiski traucējumi un pašnāvnieciska uzvedība starp pašnāvību izdarījušu vai pašnāvību izdarīt mēǵinājušu skolēnu vienaudžiem. Tika anketēti 2704 respondenti no skolām, kurās kāds no skolēniem ir izdarījis pašnāvību, un 1969 skolēni no skolām, kurās skolēnu pašnāvības pēdējo 3 gadu laikā nav reǵistrētas. Analīze tika veikta trīs skolēnu grupās: skolēni, kuri piedz̄ivojuši vienaudža pašnāvības mēǵinājumu, skolēni, kuri piedzīvojuši vienaudža pašnāvību, un kontroles grupa bez šādas pieredzes (vidējais vecums: 15,1-16,6 gadi, atkarībā no grupas). Pētījumā iegūtie dati liecina, ka skolēniem, kuri pieredzējuši vienaudža pašnāvības mēǵinājumu, ir lielākas izredzes domām par pašnāvību $(\mathrm{OR}=2,71)$, pašnāvības plānam $(\mathrm{OR}=2,61)$ un pašnāvības mēǵinājumam $(\mathrm{OR}=3,13)$, tāpat arī skolēniem, kuri pieredzējuši vienaudža pašnāvību, ir lielākas izredzes domām par pašnāvību $(O R=1,41)$, pašnāvības plānam $(O R=1,71)$ un pašnāvības mēǵinājumam (OR = 1,73), salīdzinot ar skolēniem, kuri attiecīgi pašnāvības mēǵinājumu vai pašnāvību nebija pieredzējuši, samērojot arī ar psihisku traucējumu esamību (Ho et al., 2000).

Arī citos pētījumos atklāta saikne starp pusaudža un jauniešu draugu vai vienaudžu izdarītu pašnāvību vai pašnāvības mēg̊inājumu un paša pusaudža pašnāvniecisku uzvedību vai paškaitējumu (Portzky, De Wilde and van Heeringen, 2008; Borowsky, Ireland and Resnick, 2001; Cerel, Roberts and Nilsen, 2005; Feigelman and Gorman, 2008).

Atšķirīgi rezultāti iegūti citā ASV vienas vidusskolas ietvaros veiktā pētījumā, kurā saistību izpētei starp pieredzētu drauga vai paziņas pašnāvību un paša pusaudža domām par pašnāvību, un cita veida pašnāvniecisku uzvedību analizēti pusaudži ar vidējo vecumu 16,3 gadi. No 216 respondentiem tika atlasīti 27 pusaudži, kuri piedzīvojuši drauga vai paziņas pašnāvību, un 27 respondenti kontroles grupā, kuri atbilstoši atlasīti pēc dzimuma, vecuma un etniskās piederības. Pētījumā netika pierādīta hipotēze par atšķirībām starp abām pētījuma grupām gan attiecībā uz pašnāvniecisko uzvedību, gan depresijas simptomātiku, tomēr 
pētījuma noslēgumā uzsvērts, ka secinājums par riska neesamību nevar tikt izdarīts līdz tālākā izpēte neizslēgs iespējamību, ka šāda veida rezultāti iegūti pētījuma metodoloǵijas vai izmantoto instrumentu dēl (Watkins and Gutierrez, 2003).

Zinātniskajā literatūrā aprakstīta arī pusaudžu pašnāvnieciskās uzvedības saistība ar vienaudžu vai draugu nāvi kopumā. Pētījumos analizētas dažādas likumsakarības, t.sk. noskaidrots, ka tuva drauga nāve pusaudžiem palielina depresijas simptomu izredzes (OR = 2,57) (Meyer et al., 1993), Norvēǵijā veiktā pētījumā vienas klases ietvaros noskaidrots, ka pēc pēkšņas vienaudža bojāejas vētras laikā, klasesbiedru sēru līmenis bijis tik pat augsts kā zaudējot brāli/māsu (Dyeregrov et al., 1999), Meksikā veiktā pētījumā noskaidrots, ka 12-17 gadus vecu bērnu un pusaudžu populācijā lielākas izredzes domām par pašnāvību $(O R=1,7)$, pašnāvības plānam $(\mathrm{OR}=1,8)$ un pašnāvības mēǵinājumam $(\mathrm{OR}=1,9)$ ir respondentiem, kuri bijuši cilvēka nāves liecinieki, redzējuši mirušu ķermeni, redzējuši kādu nopietni ievainotu cilvēku vai netīšām kādam izraisījuši nopietnus ievainojumus vai nāvi, vai kādu spīdzinājuši vai nogalinājuši (Borges et al., 2008).

\subsubsection{Pašnāvnieciskā uzvedība un vienaudžu ņirgāšanās}

Analizējot bērna vai pusaudža no vienaudžiem piedzīvoto vardarbību, visbiežāk zinātniskajā literatūra tiek lietoti divi termini - vienaudžu viktimizācija (angl. - peer victimization) un ņirgāšanās (angl. - bullying).

Vienaudžu viktimizācija tiek definēta kā bērna pieredze, esot citu bērnu, kuri nav bērna brālis/māsa un ne obligāti ir vienaudži, agresīvas uzvedības upurim (Hawker and Boulton, 2000), bieži elementi vienaudžu viktimizācijas definīcijās ir arī š̄is rīcības atkārtošanās, spēku nevienlīdzība starp varmāku un upuri un varmākas vēlme nodarīt upurim kaitējumu (van Geel, Vedder and Tanilon, 2014).

Savukārt ņirgāšanās (attiecībā uz upuri) definēta kā viktimizācija, kad skolēns laika gaitā atkārtoti ir pakḷauts negatīvai rīcībai no viena vai vairāku skolēnu puses, savukārt attiecībā uz varmāku ņirgāšanās definēta kā negatīva rīcība, kad kāds apzināti rada vai cenšas radīt kaitējumu, ievainot vai aizskart citu. Šì negatīvā rīcība var tikt īstenota fiziska kontakta, vārdiskā vai citos veidos, piemēram, mēdoties, rādot nepatīkamus žestus un apzināti atstumjot/izslēdzot no grupas. N̦irgāšanās jēdziens ietver arī spēku nevienlīdzību - skolēnam, kas ir ņirgāšanās upuris, ir grūtības sevi aizsargāt un viņš/viņa ir zināmā mērā bezpalīdzīgs pret varmāku, kas var būt gan viens indivīds, gan indivīdu grupa. Arī ņirgāšanās upuri var būt gan viens skolēns, gan skolēnu grupa (Olweus, 1994). 
Iepriekš veiktos pētījumos analizēta arī šāda veida vienaudžu vardarbības saistība ar pašnāvniecisko uzvedību - 2014. gadā publicēta metaanalizē, kurā analizētas vienaudžu viktimizācijas sakarības ar domām par pašnāvību un pašnāvības mēǵinājumiem bērnu un pusaudžu vidū. Tika analizēti 34 pētījumi ar kopumā 284375 dalībniekiem par šāda veida vardarbības saistību ar domām par pašnāvību un 9 pētījumi ar kopumā 70102 dalībniekiem par sakarībām ar pašnāvības mēǵinājumiem plašā vecumu amplitūdā, proti no 9 līdz 21 gadam. Metaanalīzē noskaidrots, ka vienaudžu viktimizācijas upuriem ir augstākas izredzes gan domām par pašnāvību ( $O R=2,23)$, gan pašnāvības mēǵinājumiem $(O R=2,55)$, šie rezultāti nevar tikt attiecināti uz publikācijas kḷūdu un šo sakarību būtiskumu nemazina dzimums, vecums un atšķirības analizēto pētîjumu kvalitātē. Kā viens no pētījuma ierobežojumiem norādīts plašais pētījumos izmantotais domu par pašnāvību koncepts, kas neḷauj veikt sakarību izpēti atkarībā no domu par pašnāvību smaguma pakāpes (van Geel, Vedder and Tanilon, 2014).

Līdzīgas sakarības noskaidrotas arī 2015. gadā veiktā metaanalīzēe, kurā tika iekḷauti 47 šḳērsgriezuma pētījumi (38,3\% bija ASV veikti pētījumi, 61,7\% bija citās valstīs veikti pētījumi) un analizēta saistība starp ņirgāšanos, domām par pašnāvību, un pašnāvniecisku uzvedību (šajā pētījumā domas par pašnāvību un pašnāvnieciska uzvedība ir konceptuāli nošķirtas un pie pašnāvnieciskas uzvedības pētījumos lielākoties analizēti pašnāvības mēǵginājumi). Līdzīgi kā iepriekš minētajā 2014. gadā publicētajā metaanalīzē, apliecinās sakarība, ka ṇirgāšanās upuriem ir lielākas izredzes gan domām par pašnāvību $(O R=2,34)$, gan pašnāvnieciskai uzvedībai ( $\mathrm{OR}=2,94)$, taču papildus noskaidrots, ka domas par pašnāvību un pašnāvnieciska uzvedība ir izplatītāka arī starp ņirgāšanās īstenotājiem (OR = 2,12 domām par pašnāvību; OR = 2,62 pašnāvnieciskai uzvedībai) un tiem skolēniem, kuri ir gan ņirgāšanās upuri, gan īstenotāji $(\mathrm{OR}=3,81$ domām par pašnāvību; $O R=4,02$ pašnāvnieciskai uzvedībai) (Holt et. al., 2015).

Abos iepriekš minētajos pētījumos netika noteiktas sakarības starp pašnāvniecisko uzvedību un konkrētu ņirgāšanās veidu, taču šīs sakarības analizētas pētījumā, kas veikts 10 Eiropas valstīs, aptverot 11110 pusaudžus ar vidējo vecumu 14,9 gadi. Pētījumā noskaidrots, ka lielākas izredzes domām par pašnāvību ir fiziskas ņirgāšanās (piemēram, grūšana, sišana, speršana) upuriem $(\mathrm{OR}=1,39)$, savukārt lielākas pašnāvības mēǵinājuma dzīves laikā izredzes ir starppersonu attiecību jeb sociālas ņirgāšanās (piemēram, baumu izplatīšana par upuri) upuriem $(\mathrm{OR}=1,26)$. Pētījumā netika atrasta atsevišķa sakarība starp verbālu ņirgāšanos (piemēram, apsaukāšana) un pašnāvniecisku uzvedību (Barzilay et al., 2017), kas gan tika novērota (gan attiecībā uz domām par pašnāvību, gan pašnāvības mēginājumiem) pētījumā, kas veikts reprezentatīvā Austrālijas 14-15 gadus vecu pusaudžu populācijā, taču 
šajā pētījumā verbāla ņirgāšanās analizēta kopā ar starppersonu (sociālo) ņirgāšanos (Ford et al., 2017).

Tāpat vairāk nekā astoṇas $(\mathrm{OR}=8,4)$ reizes lielākas izredzes domām par pašnāvību pieredzētas verbālas ṇirgāšanās gadījumā, salīdzinot ar pētījuma dalībniekiem, kuri nav piedzīvojuši verbālu ņirgāšanos, atklātas arī pētījumā, kas veikts 270 pacientu ar vidējo vecumu 14,4 gadi vidū, kuri nonākuši Kanādas stacionāru neatliekamās palīdzības nodaḷās ar psihiskās veselības sūdzībām (Alavi et al., 2017).

Līdzīgi kā citu iepriekš analizētu pusaudžu pašnāvnieciskās uzvedības riska faktoru gadījumā, arī dati par ņirgāšanās izplatību Latvijas pusaudžu populācijā iezīmē negatīvu situāciju. 39 valstu un reǵionu vidū, kas piedalījušies Skolēnu veselības paradumu pêtījuma 2013./2014. gada posmā. Latvijā ir otrais augstākais 15 gadus vecu skolēnu īpatsvars, kuri vismaz 2-3 reizes pēdējo pāris mēnešu laikā cietuši no ņirgāšanās skolā $-17 \%$ meiteṇu un 18\% zēnu, kas gan meitenēm, gan zēniem ir par 9 procentpunktiem augstāk par vidējiem rādītājiem pētījuma dalībvalstīs. Latvija ieṇem otro vietu pētījuma dalībvalstu vidū arī pēc 15 gadus vecu pusaudžu īpatsvara, kuri vismaz 2-3 reizes pēdējo pāris mēnešu laikā ir ņirgājušies par citiem (WHO, 2016).

\subsection{Pašnāvnieciskā uzvedība un pusaudža individuālie faktori}

\subsubsection{Pašnāvnieciskā uzvedība un depresija}

Psihologisiskās autopsijas pētijumi liecina, ka psihiski traucējumi konstatējami pat $90 \%$ no pašnāvības upuriem populācijā (Cavanagh et al., 2003) un garastāvokḷa traucējumi (jo īpaši depresija) šajā gadījumā ir visbiežāk diagnosticējamā psihisko traucējumu grupa (Gustafsson and Jacobsson, 2000; Lesage et al., 1994; Hirokawa et al., 2012).

Depresijas gadījumā vērojams nomākts garastāvoklis, tāpat vērojama energijijas, spējas priecāties, interešu, koncentrēšanās spēju un aktivitātes samazināšanās, smaga nogurdināmība, miega traucējumi, samazināta ēstgriba, zems pašnovērtējums, zema pašpaḷāvība un nereti, pat vieglos gadījumos, savas vainas vai mazvērtības idejas (Pasaules veselības organizācija [PVO], 2015) un šie simptomi klīniskas depresijas gadījumā tiek novēroti vismaz 2 nedēḷas, lielāko dienas dal̦u (Tērauds u. c., 2009).

Bērnu un pusaudžu vidū depresijas būtība parasti atšḳiras no pieaugušajiem un vairāk raksturojas ar specifisku rīcību/uzvedību - skolas kavēšanu, sekmības pazemināšanos, sliktu uzvedību, vardarbību, alkohola un narkotiku lietošanu, ilgāku gulēšanu un apjomīgāku ēšanu vai ēšanas traucējumiem (Krug et al., 2002), depresīvais noskaņojums nav klasisks, bet 
atšķiras ar nervozitāti, aizkaitināmību un emocionālu labilitāti (Tērauds u. c., 2009), taču pamatā depresijas diagnostiskie kritēriji bērniem un pusaudžiem ir tie paši, kas pieaugušajiem, ar dažādām simptomu izpausmēm, kas var variēt atkarībā no attīstības posma (Bhatia SK and Bhatis SC, 2007), ar vismazākajām atškirībām no pieaugušajiem pusaudžiem vecākajās vecuma grupās (15-18 gadi) (Patton et al., 2000).

Kopējā, vidējā klīniski nozīmīgas depresijas izplatība pusaudžu vecuma grupā 13-18 gadi ir 5,6\%-4,6\% zēniem un 5,9\% meitenēm (Erkanli and Angold, 2006), taču pusaudžu skaits ar depresijas simptomiem, kuri nesasniedz klīniski nozīmīgas depresijas kritērijus, ir vēl augstāks (Cuijpers et al., 2006).

Jau iepriekš 1.2.3. nodaḷā pieminētajā Austrālijā veiktajā pētījumā par 12-17 gadus veciem bērniem un pusaudžiem cita starpā pētīta arī pašnāvnieciskās uzvedības saistība ar klīniski nozīmīgu depresiju. Uz anketas jautājumiem atbildēja gan pats mērḳa grupas respondents, gan kāds no viṇa vecākiem. Pētījumā noskaidrots, ka respondentiem, kuriem klīniski nozīmīga depresija noteikta pēc pašu atbildēm, pat pēc samērošanas ar virkni citiem pētītajiem faktoriem ir teju septiņpadsmit reizes lielākas izredzes domām par pašnāvību pēdējā gada laikā $(\mathrm{OR}=16,9)$ un pašnāvības mēǵinājumam pēdējā gada laikā $(\mathrm{OR}=16,8)$, salīdzinot ar bērniem un pusaudžiem, kuriem pēc atbildēm uz jautājumiem klīniski nozīmīga depresija netika noteikta. Arī analizējot vecāku atbildes par respondentiem pēc samērošanas ar citiem pētītajiem faktoriem, bērniem un pusaudžiem ar klīniski nozīmīgu depresiju tika konstatētas lielākas izredzes domām par pašnāvību pēdējā gada laikā $(\mathrm{OR}=3,0)$ un pašnāvības mēginājumam pēdējā gada laikā $(\mathrm{OR}=4,5)$, tomēr redzams, ka izredžu attiecības šajā gadījumā ir salīdzinoši mazākas (Zubrick et al., 2017).

Citā Austrālijā veiktā pētījumā 2028 pusaudžu vidū ar vidējo vecumu 13,5 gadi analizēta domu par pašnāvību saistība ar depresijas simptomu līmeni, kas tika mērīts, izmantojot Epidemioloǵisko pētījumu centra Depresijas skalu (angl. - Centre for Epidemiological Studies Depression Scale) (CES-D), kura starptautiski tiek plaši izmantota pētījumos ar pusaudžiem, lai noteiktu atšķirības depresijas simptomu izplatībā starp dažādām pusaudžu populācijas grupām. Iegūtie rezultāti liecina par statistiski nozīmīgu pozitīvu lineāru sakarību starp depresijas simptomu līmeni un respondentu domām par pašnāvību. Katra viena punkta pieaugums CES-D skalā palielināja izredzes domām par pašnāvību gan zēniem (OR = 1,12), gan meitenēm $(\mathrm{OR}=1,13)$ (Allison et al., 2001).

Savukārt ASV veiktā pētījumā 13-18 gadus vecu pusaudžu vidū cita starpā analizēta arī saistība starp psihiskiem traucējumiem un pašnāvniecisku uzvedību. Sakarība starp dažāda veida psihiskiem traucējumiem un pašnāvības mēginājumiem analizēta atsevišķā regresijas modelī. Noskaidrots, ka pat pēc samērošanas ar citiem pētītajiem psihisko traucējumu 
veidiem, pusaudžiem ar klīniski nozīmīgu depresiju un/vai distīmiju ir lielākas izredzes pašnāvības mēǵinājumam ( $\mathrm{OR}=6,2)$, salīdzinot ar respondentiem bez klīniski nozīmīgas depresijas un/vai distīmijas (Nock et al., 2013).

Sakarības starp pašnāvniecisko uzvedību, depresiju un depresijas simptomu ilgumu atrastas arī citos pusaudžu populāciju raksturojošos pētījumos (Wild, Flisher and Lombard, 2004; Zubrick et al., 2017).

\subsubsection{Pašnāvnieciskā uzvedība un pašcieṇa}

Pašcieņa (angl. - self-esteem) ir jēdziens, kas atspoguḷo personas vispārējo novērtējumu par savu vērtību un ietver uzskatus, un emocijas, tādas kā triumfs, izmisums, lepnums un kauns (Meszaros and De Wals, 2011).

Pašcieṇa nosaka indivīda pārliecību par savu piemērotību dzīvei un dzīves izvirzītajām prasībām, ir pārliecība spējā domāt, pārvarēt dzīves izaicinājumus, pārliecība par tiesībām būt laimīgam, sajūta, ka esi novērtēts, uzmanības cien̄̄gs, ar tiesībām aizstāvēt savas vajadzības un vēlmes, kā arī baudīt savu centienu auglus. Pašcieṇa ir cilvēka normālas un veselīgas attīstības neatnememama sastāvdaḷa (Branden, 1990).

Šveicē veikts ekoloǵiskais pētījums, kurā analizēta saistība starp pašcieṇas līmeni un pabeigtu pašnāvību rādītājiem vispārējā populācijā 55 valstu vidū. Pētījumā noskaidrots, ka mirstība no pašnāvībām ir augstāka valstīs ar relatīvi zemu iedzīvotāju pašcieņas līmeni un šì saistība saglabājas konsekventa starp dzimumiem, vecuma grupās un neatkarīga no citiem analizētajiem faktoriem, t.sk. ekonomiskās labklājības, subjektīvās labklājības un neirotisma līmeņa. Pētījuma diskusijas daḷas noslēgumā minēts, ka pašcieṇas kā mainīgā ietekmei nevajadzētu tikt "atstātai novārtā" pašnāvību profilakses programmās (Chatard, Selimbegović and Konan, 2009).

Ṇemot vērā jau iepriekš pieminēto pabeigtu pašnāvību ciešo saikni ar pašnāvniecisku uzvedību, rodas jautājums par pašcieņas saistību ar pašnāvniecisko uzvedību pusaudžu populācijā, kas analizēta tālāk aprakstītajos pētījumos.

Dievidāfrikā veikts pētījums, kurā analizēta domu par pašnāvību un pašnāvības mēǵinājumu saistība ar depresiju un pašcieṇas līmeni 8. un 11. klašu skolēnu vidū. Pêtījumā sakarību ar pašnāvniecisko uzvedību analīzei no kopējā pašcieņas koncepta izdalīti seši atsevišḳi pašcieņu veidojošie elementi - personīgās vērtības apziṇa, "popularitāte" vienaudžu vidū, apmierinātība ar no gimenes saņemto mīlestību, apmierinātība ar saviem sasniegumiem sportā/fiziskajās aktivitātēs un attieksme pret savu ķermeni. Pirms samērošanas ar depresiju skolēniem ar zemiem rādītājiem katrā no izdalītajiem pašcieņas elementiem konstatēts 
statistiski nozīmīgi lielāks risks gan domām par pašnāvību $(R R R=1,65-2,41$, atkarībā no analizētā pašcieṇu veidojošā elementa), gan pašnāvības mēǵinājumiem (RRR = 2,19-5,96, atkarībā no analizētā pašcieņu veidojošā elementa), taču pēc samērošanas ar depresiju statistiski nozīmīga sakarība saglabājusies tikai ar zemu apmierinātību ar no gimenes saṇemto mīlestību (RRR = 1,47 domām par pašnāvību; 3,68 pašnāvības mēǵinājumam) (Wild, Flisher and Lombard, 2004). Savukārt vienā no Kanādas provincēm veiktā pētījumā 14-20 gadus vecu $(n=2372)$ jauniešu vidū atklāta saistība starp zemu pašcieņas līmeni un domām par pašnāvību, un pašnāvības plāniem arī pēc samērošanas ar depresiju, taču tikai zēnu vidū (Wang et al., 2003).

Arī citos pētījumos atklāta saistība starp zemu pašcieņas līmeni un pašnāvniecisko uzvedību (Overholser et al., 1995; Lakey et al., 2014; Tomori and Zalar, 2000; Bridge, Goldstein and Brent, 2006).

Skotijā veiktā prospektīvā pētījumā analizēta arī pusaudža pašcieņas līmeņa saistība ar paškaitējumu. Iegūtie dati par 737 15-16 gadus veciem skolēniem liecina, ka pašcieņa ir neatkarīgi saistīta ar atkārtotu paškaitējumu - katra viena punkta vērtības pieaugums pētījumā izmantotajā pašcieņas skalā (salīdzinot ar vidējo) pētītajā laika periodā (seši mēneši) neatkarīgi no citiem faktoriem bija statistiski nozīmīgi saistīts ar mazākām izredzēm atkārtotam paškaitējumam ( $O R=0,82)$ (O'Connor, Rasmussen and Hawton, 2009). Savukārt Austrālijā veiktā pētîjumā 2637 12-18 gadus vecu skolēnu vidū atklāta zema pašcieņas līmeņa saistība ar pagātnē veiktu paškaitējumu un šādas rīcības uzsākšanu, kā arī augstāka pašcieņas līmeņa saistība ar šīs rīcības pārtraukšanu (Tatnell et al., 2014).

\subsubsection{Pašnāvnieciskā uzvedība un veselības pašvērtējums}

Zinātniskās literatūras analīze liecina, ka pētījumos bieži tiek analizēta dažādu psihisko saslimšanu (piemēram, depresijas) un psihoemocionālo stāvokḷu (piemēram, bezpalīizības sajūta) saistība ar pašnāvniecisko uzvedību gan pusaudžu, gan pieaugušo vidū, taču ievērojami mazāks ir to pētījumu skaits, kuros pētnieki pievērsušies sakarību analīzei starp pusaudža somatisko veselību un pašnāvniecisku uzvedību.

Vairākos pētījumos noskaidrota pabeigtu pašnāvību saistība ar virkni somatisku saslimšanu (Ahmedani et al., 2017; Bolton et al., 2015; Webb et al., 2012), kā arī sāpju saistība ar pabeigtu pašnāvību un pašnāvniecisku uzvedību (Ilgen et al., 2013; Calati et al., 2015), taču šie pētījumi lielākoties īstenoti pieaugušo populācijās un pamatā ietver hroniskas saslimšanas, kuru izplatība likumsakarīgi pieaug līdz ar vecumu. 
Arī pētījumos, kas veikti pusaudžu populācijās tomēr iezīmējas neatkarīga sliktas somatiskās veselības un nespējas saistība ar pašnāvniecisku uzvedību (Bridge, Goldstein and Brent, 2006). Veselības jomas populācijas pētījumos bieži izmantots mērījums ir veselības pašvērtējums (angl. - self-rated health), kas ir subjektīvs vispārējās veselības indikators (WHO, 2016), attiecīgi ietverot gan psihisko, gan somatisko komponenti. Pētījumos noskaidrots, ka veselības pašvērtējums var būt arī mirstības prognostiskais rādītājs (Idler and Benyamini, 1997; Larsson et al., 2002), tomēr zinātniskajā literatūrā nav pieejami daudz pētījumi, kuros analizēta veselības pašvērtējuma saistība ar pašnāvniecisko uzvedību.

Dienvidkorejā 12-18 gadus vecu bērnu un pusaudžu populācijai reprezentatīvā pētījumā ar 72623 respondentiem cita starpā analizēta arī veselības pašvērtējuma saistība ar domām par pašnāvību un pašnāvības mēǵinājumiem pēdējā gada laikā. Noskaidrots, ka tiem bērniem un pusaudžiem, kuri atzīmējuši, ka viņu veselības stāvoklis ir vidējs, zem vidējā vai slikts, ir attiecīgi 1,42; 2,19 un 3,83 reizes lielākas izredzes domām par pašnāvību un attiecīgi 1,24; 1,89 un 3,39 reizes lielākas izredzes pašnāvības mēǵinājumam, salīdzinot ar respondentiem, kuri atzīmējuši, ka viņu veselības stāvoklis ir teicams (Kang et al., 2015).

Līdzịgs reprezentatīvs pētījums ar 12-18 gadus respondentiem veikts arī ASV Kolorado štatā. Pētījuma rezultāti liecina par atšķirībām starp dzimumiem - noskaidrots, ka meitenēm ar sliktu veselības pašvērtējumu ir augstākas izredzes domām par pašnāvību (OR = 3,96) un pašnāvības mēǵinājumiem $(\mathrm{OR}=4,13)$, salīdzinot ar meitenēm ar labu veselības pašvērtējumu, taču zēnu vidū šī sakarība nav izrādījusies statistiski nozīmīga (NkansahAmankra, Walker and Clark, 2009).

Ar pašnāvniecisko uzvedību saistītie faktori pētīti arī Peru, 916 pilsētas skolas apmeklējošo pusaudžu vidū ar vidējo vecumu 15 gadi. Lai arī nesamērotās izredžu attiecības pusaudžiem, kuru veselības pašvērtējums ir slikts vai zem vidējā, uzrādījušas lielākas izredzes domām par pašnāvību $(\mathrm{OR}=2,21)$ un pašnāvības mēginājumiem $(\mathrm{OR}=2,40)$, salīdzinot ar pusaudžiem, kuru veselības pašvērtējums ir labs, pēc samērošanas ar citiem pētītajiem faktoriem sakarības nav saglabājušās statistiski nozīmīgas (Sharma et al., 2015).

No slikta veselības pašvērtējuma izrietošo negatīvo konsekvenču analīze pusaudžu vidū Latvijā būtisku nozīmi iegūst ievērojamā pusaudžu īpatsvara dēḷ, kuri Latvijā savu veselības stāvokli novērtē kā viduvēju un sliktu. Starp 39 valstīm un reǵioniem, kas piedalījušies jau iepriekš vairākkārt pieminētajā Skolēnu veselības paradumu pētījuma 2013./2014. gada posmā, Latvijā vērojams augstākais 15 gadus vecu skolēnu īpatsvars, kuri savu veselību novērtē kā viduvēju un sliktu - šādu vērtējumu savai veselībai snieguši 38\% meiteņu un 14\% zēnu, kas ir par 17 procentpunktiem meitenēm un 1 procentpunktu zēniem vairāk par vidējiem rādītājiem pētîjuma dalībvalstīs (WHO, 2016). 


\subsubsection{Pašnāvnieciskā uzvedība un atkarību izraisošo vielu lietošana}

Pusaudžu vecums ir būtisks neiroloǵiskās attīstības periods. Pētījumos ir atklāts, ka pusaudžiem, kas lieto atkarību izraisošās vielas, ir vērojamas novirzes smadzeņu funkcijās, kas saistītas ar izmaiṇām neirokognitīvajos procesos, smadzeṇu struktūrā, apjomā, baltās vielas kvalitātē un kognitīvās aktivēšanas procesos, kas var atšķirties atkarībā no lietotās vielas. Piemēram, riskanta alkohola lietošana pusaudža vecumā var veicināt kavētus ar atminu saistītos kognitīvos procesus, kā arī pasliktināt ar uzmanību un uzdevumu izpildi saistītās kognitīvās funkcijas (Squeglia, Jacobus and Tapert, 2009). Tāpat noskaidrots, ka pusaudžiem ar atkarību izraisošo vielu lietošanas problēmām bieži vērojami garastāvokḷa traucējumi, ar negatīvo stresu saistīti notikumi dzìvēe, problēmas starppersonu attiecībās, reducēts sociālais atbalsts, vientulība un bezpalīdzības sajūta (Pompili et al., 2012) kā arī depresija (Bond et al., 2005).

Pētījumu dati liecina, ka atkarību izraisošo vielu lietošana pusaudžu populācijā ir plaši izplatīta arī Latvijā. Pētījuma "Atkarību izraisošo vielu lietošanas paradumi un tendences skolēnu vidū” 2015. gada dati liecina, ka Latvijā par regulāriem smēḳētājiem (dienā izsmēḳē vismaz vienu cigareti) ir uzskatāmi 15,7\% 15 gadus veco pusaudžu, dzīves laikā alkoholu 40 un vairāk reižu lietojis katrs piektais (20,5\%) pusaudzis, 44,0\% pusaudžu dzīves laikā piedzērušies, bet kaut reizi kādu no narkotikām pamēǵinājuši 19,0\% iepriekš minētās vecuma grupas pusaudžu (Sniķere un Trapencieris, 2016), kas aktualizē šī ievērojamā pusaudžu īpatsvara ar atkarības vielu lietošanu saistītā riska (t.sk. pašnāvnieciskās uzvedības) analīzes nozīmi.

Taivānā veikts pētījums, lai noskaidrotu atkarību izraisošo vielu lietošanas saistību ar pašnāvniecisko uzvedību 12-19 gadus vecu zēnu un meiteṇu vidū. Tika aptaujāti 13985 respondenti un noskaidrots, ka abu dzimumu skolēni, kuri pēdējā gada laikā smēḳējuši cigaretes vismaz vienu reizi katru nedēḷu, pēdējā gada laikā lietojuši alkoholu vismaz vienu reizi katru nedēḷu, jebkad lietojuši ketamīnu vai jebkad lietojuši ekstaz̄̄, biežāk atzīmē gan domas par pašnāvību, gan pašnāvības plānus, gan pašnāvības mēǵinājumus, salīdzinot ar respondentiem, kuri iepriekš minētās atkarību izraisošās vielas nav lietojuši. Neskatoties uz faktu, ka zēni atkarību izraisošās vielas lietojuši biežāk, statistiski nozīmīga sakarība ar visiem pētītajiem pašnāvnieciskās uzvedības veidiem apstiprinājusies gan zēniem, gan meitenēm (Wang and Yen, 2017).

Jau iepriekš vairākkārt minētajā pētījumā par 15-16 gadus veciem pusaudžiem 17 Eiropas valstīs analizēta arī pašnāvnieciskās uzvedības saistība ar atkarību izraisošo vielu lietošanu. Noskaidrots, ka skolēniem, kuri izsmēḳējuši vismaz vienu cigareti dienā pēdējo 30 
dienu laikā, lietojuši alkoholu vismaz 10 reizes pēdējo 30 dienu laikā vai dzīves laikā lietojuši marihuānu, amfetamīnu, LSD vai citus halucinogēnus, kreku, kokaīnu, heroīnu vai ekstazī, ir lielākas izredzes biežām domām par paškaitējumu piecas un vairāk reizes dzīves laikā (OR = 2,21 smēķētājiem; OR = 1,43 alkohola lietotājiem; OR = 1,73 narkotisko vielu lietotājiem) un pašnāvības mēginājumam dzīves laikā $(\mathrm{OR}=2,14$ smēḳētājiem; OR = 1,49 alkohola lietotājiem; OR = 2,22 narkotisko vielu lietotājiem), salīdzinot ar skolēniem, kuri smēḳējuši vai lietojuši alkoholu mazāk par definēto daudzumu vai dzīves laikā norādītās narkotikas nav lietojuši (Kokkevi et al., 2012).

Arī pētījumā, kas veikts četrās Okeānijas Klusā okeāna salu valstīs apstiprinājusies sakarība starp pašnāvniecisko uzvedību un atkarību izraisošo vielu lietošanu. Aptaujājot 6540 13-16 gadus vecus pusaudžus, noskaidrots, ka respondentiem, kuri definēti kā smēķētāji (smēķējuši cigaretes katru dienu pēdējo 30 dienu laikā), alkohola lietotāji (lietojuši alkoholu saturošus dzērienus katru dienu pēdējo 30 dienu laikā) vai marihuānas lietotāji (smēķējuši marihuānu katru dienu pēdējo 30 dienu laikā), ir lielākas izredzes domām par pašnāvību (OR = 2,73 smēḳētājiem; OR = 2,69 alkohola lietotājiem; OR = 3,18 marihuānas lietotājiem) un pašnāvības mēǵinājumiem (OR = 4,29 smēḳētājiem; $O R=4,16$ alkohola lietotājiem; $O R=$ 7,33 marihuānas lietotājiem), salīdzinot ar respondentiem, kuri pēdējo 30 dienu laikā iepriekš minētās atkarību izraisošās vielas nav lietojuši. Arī šajā pētījumā sakarības bijušas statistiski nozīmīgas gan zēniem, gan meitenēm (Peltzer and Pengpid, 2015).

Līdzīgā pētījumā ASV ar 1458 respondentiem pēc samērošanas ar depresiju, trauksmi un uzvedības traucējumiem vairs nebija vērojama statistiski nozīmīga saistība starp domām par pašnāvību un neregulāru smēḳēšanu, regulāru smēķēšanu, alkohola lietošanu, riskantu alkohola lietošanu/atkarību un narkotiku lietošanu, taču saglabājās statistiski nozīmīgi lielākas izredzes pašnāvības mēǵinājumiem starp regulārajiem smēḳētājiem (vismaz viena cigarete dienā pēdējo sešu mēnešu laikā) $(O R=3,0)$, salīdzinot ar respondentiem, kuri pēdējā gada laikā nebija smēķējuši, riskantajiem alkohola lietotājiem/no alkohola atkarīgajiem $(\mathrm{OR}=9,3)$, salīdzinot ar respondentiem, kuri nebija lietojuši alkoholu 6 vai vairāk reizes pēdējā gada laikā un narkotiku lietotājiem (jebkuras nelegālās narkotiskās vielas pēdējā gada laikā) (OR = 4,6), salīdzinot ar respondentiem, kuri nelegālās narkotiskās vielas pēdējā gada laikā nav lietojuši. Šajā pētījumā gan apsekota plašāka respondentu grupa - 9-17 gadi (Wu et al., 2004).

Citā ASV 14-18 gadus vecu pusaudžu populācijai reprezentatīvā pētījumā ar 64671 respondentiem no 11 štatiem analizētas sakarības starp pusaudžu pašu ziņoto paškaitējumu un plaša spektra asociētajiem faktoriem. Pēc samērošanas ar citiem pētītajiem faktoriem cita starpā tika noskaidrots, ka cigarešu smēḳēšana vismaz vienu reizi pēdējo 30 dienu laikā un 
"spēcīgo" narkotiku (piemēram, kokaīns, metamfetamīns, heroīns) lietošana jebkad dzīves laikā palielina izredzes paškaitējumam (OR = 1,38 smēķēěšanai; OR = 1,61 "spēcīgajām" narkotikām), savukārt sakarība starp alkohola un marihuānas lietošanu pēdējā pēdējo 30 dienu laikā un paškaitējumu netika konstatēta(Monto, McRee and Deryck, 2018). 


\section{MATERIĀLS UN METODES}

\subsection{Datu avoti un ieguve}

Promocijas darba izstrādē izmantoti dati no Slimību un profilakses kontroles centra 2011. gada Eiropas skolu aptaujas projekta par alkoholu un citām narkotiskajām vielām (angl. - European School Survey Project on Alcohol and Other Drugs) (ESPAD).

ESPAD primārais mērḳis ir pēc vienotas metodologijas iegūt starptautiski salīdzināmums datus par atkarību izraisošo vielu lietošanu noteikta vecuma skolēnu vidū, lai monitorētu tendences gan katras valsts, gan starpvalstu līmenī. Pētījums kopš 1995. gada tiek īstenots reizi četros gados un 2011. gada posmā ietver datus kopumā par vairāk kā 100000 skolēniem 36 valstīs, t. sk. Latvijā (Hibell et al., 2012). Promocijas darba izstrādē izmantoti Latvijas dati, kur 2011. gada pētījuma posma mērḳa populācija bija vispārizglītojošo skolu 8.-10. klašu skolēni.

Pētījuma instruments bija aprobēta, standartizēta aptaujas anketa latviešu un krievu valodās. Aptaujas anketā tika koriǵēti atsevišşi jautājumi, kuri tika validēti divās fokusa grupas diskusijās ar mērḳa grupas pusaudžiem pirms pētījuma lauka darba uzsākšanas. Tāpat aptaujā izmantoti atsevišḳi papildus jautājumu moduḷi (t. sk. psihosociālais modulis), kas iekḷauti jau 2007. gada pētījuma anketā (Trapencieris u. c., 2012). Attiecībā uz pašnāvniecisko uzvedību aptaujas anketā iekḷauti gan jautājumi no ESPAD psihosociālā moduḷa, gan atsevišḳi, specifiski izstrādāti jautājumi papildus informācijas iegūšanai par pusaudžu pašnāvniecisko uzvedību un pieredzi. Jautājumu izstrādē piedalījies arī promocijas darba autors.

Pētījuma dalībnieku atlasei tika izmantota stratificēta klāsteru gadījumizlase, kurā kā izlases pamatvienība bija klase. Izlase veidota atbilstoši IZM datiem par 8.-10. klašu un tajās esošo skolēnu skaitu 2010./2011. mācību gadā. Varbūtība katras klases iekḷaušanai izlasē bija atkarīga no audzēkṇu skaita klasē. Dēḷ fakta, ka standarta anketas aizpildīšana varētu būt problemātiska, atbilstoši ESPAD izlases veidošanas vadlīnijām no izlases tika izslēgti skolēni, kuri mācās speciālās skolās un/vai klasēs bērniem ar nopietniem garīgās un/vai fiziskās veselības traucējumiem (Trapencieris u. c., 2012). 2.1. tabulā redzams izlasē ieklauto skolēnu un klašu skaits. 
Izlases rāmī iekḷauto klašu un skolēnu skaits

\begin{tabular}{|l|c|c|}
\hline \multicolumn{1}{|c|}{ Klases līmenis } & Klašu skaits & Skolēnu skaits \\
\hline 8. & 1019 & 18208 \\
\hline 9. & 1123 & 19884 \\
\hline 10. & 604 & 13086 \\
\hline
\end{tabular}

Pēc izlases rāmja izveidošanas 8., 9. un 10. klases tika stratificētas atbilstoši 114 stratām, šo stratu lielumu aprēķinot atbilstoši IZM statistikai par audzēkṇiem 2010./2011. mācību gadā vispārizglītojošās izglîtības iestādēs Rīgā, kā arī valsts nozīmes pilsētās (Daugavpils, Liepāja, Ventspils, Jelgava, Rēzekne, Jūrmala, Valmiera, Jēkabpils), katrā veidojot sešas stratas (pēc klases līmeņa un mācību valodas), reǵionos - pēc urbanizācijas līmeṇa skolas atrašanās vietā, Valsts regiionālās attīstības aǵentūras 2009. gada teritoriju attīstības indeksa un klases līmeņa. Lai noteiktu izlasē iekḷaujamo klāsteru (klašu) skaitu, atbilstoši stratifikācijas pazīmēm tika aprēķināts skolēnu un klašu skaits katrā stratā, kā arī vidējais aritmētiskais skolēnu skaits stratā. Pamatojoties uz šiem aprēḳiniem, kā arī ņemot vērā iespējamo skolēnu nerespondenci, tika aprēḳināts izlasē iekḷaujamais klašu un skolēnu skaits. N̦emot vērā potenciālo nerespondenci, aprēķinātais sasniedzamās izlases apjoms bija 7938 skolēni. Atbilstoši aprēḳinātajam klašu skaitam, kuras nepieciešams iekḷaut izlasē, no visu klašu saraksta pēc nejaušǐbas principa tika atlasītas klases, kuru iekḷaušanas varbūtība bija proporcionāla audzēkṇu skaitam klasē. Kopumā tika atlasītas 519 klases (173 klases 8. klases, 193 - 9. klases un 153 - 10. klases) (Trapencieris u. c., 2012).

Aptauja tika veikta 2011. gada aprīịa un maija mēnešos. Aptaujā piedalījās skolēni no 491 klases 327 vispārizglītojošajās skolās. Tikai no 14 mācību iestādēm tika saṇemti atteikumi. Dēl atteikumiem, neprecīzās informācijas par skolēnu skaitu klasē kā arī skolēnu kavējumiem, realizētās izlases apjoms bija 7 716. Pēc atsevišķu praktiski neaizpildītu anketu izslēgšanas datu failā tika iekḷautas 7627 8.-10. klašu skolēnu anketas (Trapencieris u. c., 2012).

Papildus promocijas darba ietvaros no analīzes tika izslēgtas 250 skolēnu anketas, kurās nebija norādīts skolēna dzimšanas gads vai mēnesis, un 78 anketas, kurās skolēni nebija snieguši atbildi uz anketas jautājumu atkarīgās pazīmes - domu par pašnāvību un atkarīgās pazīmes - pašnāvības mēǵinājuma noteikšanai. Kopumā promocijas darbā analizēti dati par 7299 respondentiem. 2.2. tabulā norādīta informācija par promocijas darba ietvaros analizētās skolēnu atlases struktūru. 
Promocijas darba ietvaros analizētās atlases struktūra

\begin{tabular}{|l|c|c|c|}
\hline Klases lïmenis & Zēni & Meitenes & Kopā \\
\hline 8. & 1137 & 1147 & 2284 \\
\hline 9. & 1361 & 1368 & 2729 \\
\hline 10. & 973 & 1313 & 2286 \\
\hline Dz̄̄vesvieta & \multicolumn{5}{|l|}{} \\
\hline Rīga & 865 & 902 & 1767 \\
\hline Lielās pilsētas & 797 & 969 & 1766 \\
\hline Citas pilsētas & 1136 & 1268 & 2404 \\
\hline Lauki & 673 & 689 & 1362 \\
\hline Vecums & \multicolumn{5}{|l|}{} \\
\hline 14 & 574 & 674 & 1248 \\
\hline 15 & 1169 & 1253 & 2422 \\
\hline 16 & 1150 & 1308 & 2458 \\
\hline 17 & 578 & 593 & 1171 \\
\hline
\end{tabular}

\subsection{Pētāmo mainīgo pazīmes un grupēšana}

\section{Atkarīgās pazīmes}

Kā atkarīgās pazīmes promocijas darbā analizēti sekojoši pašnāvnieciskās uzvedības veidi:

- domas par pašnāvību dzīves laikā (turpmāk - domas par pašnāvību), kuru noteikšanai respondentiem anketā bija jāatbild uz jautājumu, vai respondents ir pārdomājis/-usi konkrētu veidu, vietu vai rīcību pašnāvības izdarǐšanai, atzīmējot kādu no piedāvātajiem atbilžu variantiem - “nē”, “jā, pēdējo 12 mēnešu laikā” vai “jā, dz̄ives laikā”. Atbilžu varianti tika dihotomizēti, izveidojot divas grupas - "jāà", kas noteikta, ja respondents atzīmējis atbilžu variantu “jā, pēdējo 12 mēnešu laikā" vai "jāa, dzīves laikā" un "nē", ja respondents uz jautājumu atbildējis noliedzoši. N,emot vērā pastāvošās atšḳirības zinātniskajā literatūrā domu par pašnāvību definēšanā un pētījumos uzdotajos jautājumos domu par pašnāvību noskaidrošanai, kā arī ņemot vērā nepieciešamību diferencēt domas par pašnāvību ar salīdzinoši augstāku risku pašnāvības mēǵinājumam vai pabeigtai pašnāvībai, promocijas darba ietvaros izmantotā, respondentiem uzdotā jautājuma 
konstruēšanā izmantota jaunākā zinātniskā pieeja domu par pašnāvību definēšanā, kurā tiek izdalītas aktīvas un pasīvas domas par pašnāvību, aktīvas domas par pašnāvību definējot kā domas par rīcību savas dzīves izbeigšanai, ietverot metodes identificēšanu, plāna esamību vai nodomu atbilstoši rīkoties (Turecki and Brent, 2016). No visiem promocijas darba ietvaros analizētajiem respondentiem atbildi uz šo jautājumu nebija snieguši 48 (0,7\%) respondentu;

- pašnāvības mēǵinājums dz̄ves laikā (turpmāk - pašnāvības mēǵinājums), kura noteikšanai respondentiem anketā bija jāatzīmē vai un cik reižu dzīves laikā respondents ir mēǵinājis/-usi izdarīt pašnāvību, atzīmējot kādu no piedāvātajiem atbilžu variantiem "nekad", "vienu reizi”, “divas reizes", “3-4 reizes" vai "5 vai vairāk reizes”. Atbilžu varianti tika dihotomizēti, izveidojot divas grupas - “jâa”, kas noteikta, ja respondents atzīmējis kādu no pašnāvības mēǵinājuma skaita kategorijām un "nē”, ja respondents atzīmējis atbilžu variantu “nekad”. Šāds jautājums un pieeja pusaudžu pašu ziṇotā pašnāvības mēǵinājuma noteikšanai izmantoti arī vairākos citos pētījumos, kuros izmantoti ESPAD dati (Kokkevi et al., 2012; Kokkevi et al., 2011; Hibell et al., 2009), savukārt līdzīga pieeja paša jautājuma konceptā izmantota vēl vairākos pētījumos (Joe et al., 2009; Borges et al., 2008; Zarrouq et al., 2015; Zubrick et al., 2016). No visiem promocijas darba ietvaros analizētajiem respondentiem atbildi uz šo jautājumu nebija snieguši $23(0,3 \%)$ respondentu.

\section{Neatkarīgās pazīmes}

Kā neatkarīgās pazīmes promocijas darbā analizēti ar ǵimenes vidi saistītie faktori:

- nedzivošana ar abiem bioloğiskajiem vecākiem, kuras noteikšanai, atbilstoši ESPAD starptautiski izmantotajam jautājumam, respondentiem bija jāatzīmē cilvēki, kuri dzīvo ar respondentu vienā gimenē, atzīmējot piedāvātos atbilžu variantus "dzīvoju viens", "tēvs", "patēvs", "māte", "pamāte”, "brālis/brālil”, "māsa/māsas", "vecvecāki”, “citi tuvinieki”, “personas, kas nav tuvinieki”. Atbilžu varianti tika dihotomizēti, izveidojot divas grupas “jā", kas noteikta, ja respondents atzīmējis, ka nedzīvo ar abiem bioloğiskajiem vecākiem - tēvu un māti un "nē", kas noteikta, ja respondents nav atzīmējis, ka dzīvo vienā ǵimenē gan ar tēvu, gan māti. Līdzīga pieeja izmantota arī citos pētījumos (Kokkevi et al., 2012; Zaborskis, Sirvyte and Zemaitiene, 2016; Kokkevi et al., 2011);

- vecāku emocionālais atbalsts, kura noteikšanai, atbilstoši starptautiski izmantotajam jautājumam, respondentiem bija jānorāda cik bieži ir spēkā apgalvojums "Man ir viegli saṇemt emocionālo atbalstu no mātes un/vai tēva". Iespējamie atbilžu varianti bija "gandrīz 
vienmēr", "bieži”, “dažreiz", "reti” un "gandrīz nekad". Atbilžu varianti tika apvienoti, izveidojot trīs kategorijas - "vienmēr/bieži”, ja respondents atzīmējis kādu no atbilžu variantiem "gandrīz vienmēer" vai "bieži”, “dažreiz”, ja respondents atzīmējis atbilstošo atbildes variantu, un "reti/nekad", ja respondents atzīmējis kādu no atbilžu variantiem "reti" vai "gandrīz nekad". No visiem promocijas darba ietvaros analizētajiem respondentiem atbildi uz šo jautājumu nebija snieguši 63 (0,9\%) respondentu;

- pašnāvnieciska pieredze ğimenē, kuras noteikšanai respondentiem bija jāatbild uz diviem atsevišķiem jautājumiem: "Vai kāds no Taviem ǵimenes locekḷiem ir mēǵinājis izdarīt pašnāvību?" un "Vai kāds no Taviem ǵimenes locekḷiem ir izdarījis pašnāvību?” ar atbilžu variantiem "jāa dzīves laikā", "jā, pēdējo 12 mēnešu laikā" un "nē". Atbilžu varianti tika dihotomizēti, izveidojot divas grupas - “jā”, kas noteikta, ja respondents uz kādu vai abiem atsevišķajiem jautājumiem devis apstiprinošu atbildi, un “nē”, ja respondents uz abiem jautājumiem atbildējis noliedzoši. No visiem promocijas darba ietvaros analizētajiem respondentiem atbildi uz abiem jautājumiem nebija snieguši 21 (0,3\%) respondentu;

- fiziska vardarbība gimenēe, kura noteikta pēc respondentu atbildēm uz jautājumu par iesaisti fiziskā vardarbībā savās mājās, kurā piedalījās arī kāds pieaugušais, atzīmējot piedāvātos atbilžu variantus “jā, dz̄ives laikā", “jā, pēdējo 12 mēnešu laikā” vai “nē”. Atbilžu varianti tika dihotomizēti, izveidojot divas grupas - “jā”, kas noteikta, ja respondents atzīmējis kādu no apstiprinošajām atbildēm, un "nē", kas noteikta, ja respondents uz jautājumu atbildējis noliedzoši. No visiem promocijas darba ietvaros analizētajiem respondentiem atbildi uz šo jautājumu nebija snieguši $72 \quad(1,0 \%)$ respondentu;

- seksuāla uzmākšanās ğimenē, kura noteikta pēc respondentu atbildēm uz jautājumu par piedzīvotu seksuālu uzmākšanos, kurā bija iesaistīts kāds pieaugušais ǵimenes loceklis, atzīmējot piedāvātos atbilžu variantus “jā, dzīves laikā”, “jā, pēdējo 12 mēnešu laikā” vai "nē". Atbilžu varianti tika dihotomizēti, izveidojot divas grupas - “jā̄”, kas noteikta, ja respondents atzīmējis kādu no apstiprinošajām atbildēm, un “nē", kas noteikta, ja respondents uz jautājumu atbildējis noliedzoši. No visiem promocijas darba ietvaros analizētajiem respondentiem atbildi uz šo jautājumu nebija snieguši 76 (1,0\%) respondentu;

\section{ar vienaudžu vidi saistītie faktori:}

- vienaudžu emocionālais atbalsts, kura noteikšanai, atbilstoši ESPAD starptautiski izmantotajam jautājumam, respondentiem bija jānorāda cik bieži ir spēkā apgalvojums "Man ir viegli saņemt emocionālo atbalstu no mana labākā drauga/draudzenes”. Iespējamie atbilžu varianti bija "gandrīz vienmēr", "bieži”, "dažreiz", "reti” un "gandrīz nekad". 
Atbilžu varianti tika apvienoti, izveidojot trīs kategorijas - "vienmēr/bieži”, ja respondents atzīmējis kādu no atbilžu variantiem "gandrīz vienmēr" vai "bieži”, “dažreiz", ja respondents atzīmējis atbilstošo atbildes variantu, un "reti/nekad", ja respondents atzīmējis kādu no atbilžu variantiem "reti” vai "gandrīz nekad”. No visiem promocijas darba ietvaros analizētajiem respondentiem atbildi uz šo jautājumu nebija snieguši $55(0,8 \%)$ respondentu;

- pašnāvnieciska pieredze vienaudžu vidū, kuras noteikšanai respondentiem bija jāatbild uz diviem atsevišķkiem jautājumiem: "Vai kāds no Taviem draugiem vai paziṇām ir mēǵinājis izdarīt pašnāvību?" un "Vai kāds no Taviem draugiem vai paziṇām ir izdarījis pašnāvību?” ar atbilžu variantiem “jā, dzīves laikā”, “jā, pēdējo 12 mēnešu laikā” un "nē”. Atbilžu varianti tika dihotomizēti, izveidojot divas grupas - “jā̄", kas noteikta, ja respondents uz kādu vai abiem atsevišḳajiem jautājumiem devis apstiprinošu atbildi, un “nē", ja respondents uz abiem jautājumiem atbildējis noliedzoši. No visiem promocijas darba ietvaros analizētajiem respondentiem atbildi uz abiem jautājumiem nebija snieguši $40(0,5 \%)$ respondentu;

- vienaudžu ṇirgāšanās skolā, kuras noteikšanai respondentiem bija jāatbild uz jautājumu par to, cik bieži ir bijušas situācijas, kad klasesbiedri respondentu ir apsaukājuši, atzīmējot kādu no piedāvātajiem atbilžu variantiem - "nekad”, "reti”, "vidēji bieži”, "bieži” vai “vienmēr". Atbilžu varianti tika apvienoti, izveidojot trīs kategorijas - "vienmēr/bieži”, ja respondents bija atzīmējis atbilžu variantus "bieži” vai "vienmēr", “dažreiz", ja respondents bija atzīmējis atbilžu variantus "reti" vai "vidēji bieži”, un "nekad", ja respondents bija atzīmējis atbilstošo atbilžu variantu. No visiem promocijas darba ietvaros analizētajiem respondentiem atbildi uz šo jautājumu nebija snieguši 118 (1,6\%) respondentu;

\section{individuālie faktori:}

- depresijas simptomu līmenis, kura noteikšanai izmantota Epidemioloğijas pētījumu centra Depresijas skalas (angl. - Center of Epidemiological Studies Depression-Scale) (CES-D) (Radloff, 1977) īsā (sešu jautājumu) forma, kas starptautiski izmantota ESPAD psihosociālā moduḷa ietvaros (Hibell et al., 2009). CES-D skalas pamatmērḳis nav klīniski nozīmīgas depresijas diagnostika, bet gan depresijas simptomu līmeņa noteikšana, lai mērītu atšķirīibas dažādās populācijas grupās (Radloff, 1977). CES-D ir viena no skalām, kas tiek rekomendēta dažāda depresijas simptomu līmeņa noteikšanai arī pusaudžu populācijā, bet ne klīniskas depresijas diferencēšanai, jo klīniskas depresijas robežpunktu noteikšana var rezultēties kḷūdaini pozitīvā atradē (Stockings et al., 2015). Skalas īsās formas validitāte tika novērtēta salīizinot rezultātus ar pilnās CES-D skalas rezultātiem 
5249 skolēnu aptaujā un atzīta par apmierinošu (Hibell et al., 2009). Respondentiem bija jāsniedz atbildes uz sešiem jautājumiem, proti, “Cik bieži pēdējo 7 dienu laikā...” a. "Tev bija zudusi apetīte, negribējās ēst”, b. "Tev bija grūtības koncentrēties tam, ko gribēji darīt”, c. "juties nomākts/nomākta”, d. "juti, ka ir jāpiepūlas un jāpiespiež sevi izdarīt to, kas jādara”, e. "juties skumji”, f. "nespēji darīt savu darbu (mājās, darbā, skolāa)”. Atbilžu varianti uz katru jautājumu bija - "reti vai nekad”, “dažreiz”, “bieži” un "gandrīz vienmēr’". Rezultātu interpretācijā primāri tika izmantota pieeja, kas starptautiski izmantota ESPAD pētījumā (Hibell et al., 2009): atkarībā no atbildes uz katru no jautājumiem respondentam bija iespējams iegūt 1-4 punktus - augošā secībā, no 1 punkta, ja atzīmēta atbilde "reti vai nekad", līdz 4 punktiem, ja atzīmēta atbilde "gandrīz vienmēr". Pēc atbildēm uz visiem sešiem jautājumiem tika aprēķināta katra respondenta iegūtā kopējā punktu summa, pēc kuras tika aprēķināta katra respondenta vidējā sešos jautājumos iegūto punktu summa. Vadoties pēc vidējās iegūtās punktu summas sadalījuma kvartilēs, tika izdalītas trīs depresijas simptomu līmeņa kategorijas - "zems" gadījumā, ja vidējā punktu summa bija divās zemākajās kvartilēs vidējo rādītāju sadalījumā, savukārt divas augstākās kvartiles tika proporcionāli sadalītas kategorijās "vidēji augsts" un "augsts", kas papildina ESPAD pētījumā izmantoto pieeju, kurā sakarību analīzei nepieciešamā depresijas simptomu līmeņa izdalīšanai kā robežpunkts tiek definētas divas augstākās kvartiles kopā (Hibell et al., 2009). Papildinātā pieeja ḷauj papildus diferencēt respondentus augstākās depresijas simptomu izplatības grupas ietvaros, kur pašnāvnieciskās uzvedības risks potenciāli varētu būt augstāks. No visiem promocijas darba ietvaros analizētajiem respondentiem atbildi uz kādu no jautājumiem nebija snieguši 92 (1,3\%) respondentu šiem respondentiem attiecīgi punktu summas un vidējie rādītāji netika aprēķināti;

- pašcieņas līmenis, kura noteikšanai izmantota Rozenberga pašcieņas skala (angl. Rosenberg's Self-esteem Scale), kas ir instruments, kas detalizēti izstrādāts balstoties uz pašcieņas konceptu un vispārējo pašcieņu mēra, novērtējot personas uzskatus par savu personīgo vērtību un sevis pieņemšanu (Rosenberg, 1965). Skala tiek plaši izmantota pētījumos pašcieņas noteikšanai dažādās populācijās, kā arī vairākos pētījumos pusaudžu populācijāâ, kuros analizētas pašcieņas sakarības ar pašnāvniecisko uzvedību (Lakey et al., 2014; Wang et al., 2003; Tomori and Zalar, 2000). Respondentiem bija jāatbild, cik lielā mērā viṇi piekrīt 10 apgalvojumiem: a. "kopumā esmu ar sevi apmierināts/a", b. "reizēm domāju, ka nekam nederu”, c. "uzskatu, ka man ir daudzas labas īpašības”, d. "spēju visu darīt tikpat labi kā vairums cilvēku", e. "domāju, ka man nav daudz ar ko lepoties", f. "reizēm es patiešām jūtos nevērtīgs/a", g. "domāju, ka esmu vērtīgs cilvēks, vismaz līdzvērtīgs citiem", h. "vēlos, kaut man būtu vairāk pašcieņas", i. "vispār sliecos uzskatīt 
sevi par neveiksminieku", j. "es pret sevi izturos pozitīvi", no kuriem pieci apgalvojumi (a, c, d, g, j) ir pozitīvi un pieci apgalvojumi (b, e, f, h, i) ir negatīvi. Uz katru no apgalvojumiem respondentiem bija jāatzīmē kāds no atbilžu variantiem - "pilnīgi piekrītu”, "piekrītu”, "nepiekrītu” un "pavisam nepiekrītu”. Atkarībā no sniegtās atbildes uz katru no apgalvojumiem respondentam bija iespējams iegūt 1-4 punktus - augošā secībā, no 1 punkta, ja atzīmēta atbilde "pilnīgi piekrītu", līdz 4 punktiem, ja atzīmēta atbilde "nepavisam nepiekrītu" negatīvajos apgalvojumos un dilstošā secībā no 4 punktiem, ja atzīmēta atbilde "pilnīgi piekrītu", līdz 1 punktam, ja atzīmēta atbilde “nepavisam nepiekrītu” pozitîvajos apgalvojumos. Rezultātu interpretācijā primāri tika izmantota pieeja, kas starptautiski izmantota ESPAD pētījumā (Hibell et al., 2009): pēc atbildēm uz visiem desmit jautājumiem tika aprēķināta katra respondenta iegūtā kopējā punktu summa, pēc kuras tika aprēķināta katra respondenta vidējā desmit jautājumos iegūto punktu summa. Vadoties pēc vidējās iegūtās punktu summas sadalījuma kvartilēs, tika izdalītas trīs pašcieņas līmeņa kategorijas - "augsts" gadījumā, ja vidējā punktu summa bija divās augstākajās kvartilēs vidējo rādītāju sadalījumā, savukārt divas zemākās kvartiles tika proporcionāli sadalītas kategorijās "vidēji zems" un "zems", kas papildina ESPAD pētījumā izmantoto pieeju, kurā sakarību analīzei nepieciešamā pašcieņas līmeņa izdalīšanai kā robežpunkts tiek definēta tikai augstākā vidējās punktu summas sadalījuma kvartile (Hibell et al., 2009). Papildinātā pieeja ḷauj diferencēt respondentus ar vidēji zemu pašcieņas līmeni, kas ļauj papildus noteikt sakarības ar pašnāvniecisko uzvedību arī šajā respondentu grupā. No visiem promocijas darba ietvaros analizētajiem respondentiem atbildi uz kādu no desmit jautājumiem nebija snieguši 262 (3,6\%) respondentu - šiem respondentiem attiecīgi punktu summas un vidējie rādītāji netika aprēḳināti;

- veselības pašvērtējums, kura noteikšanai respondentiem bija jāatbild uz ESPAD starptautiski izmantoto jautājumu: "Cik apmierināts/-a Tu parasti esi ar savu veselības stāvokli?" ar atbilžu variantiem "l,oti apmierināts", "diezgan apmierināts", "ne apmierināts, ne neapmierināts", “diezgan neapmierināts" vai "ḷoti neapmierināts". Atbilžu varianti tika apvienoti, izveidojot trīs kategorijas - "neapmierināts", ja respondents atzīmējis kādu no atbilžu variantiem "diezgan neapmierināts" vai "ḷoti neapmierināts", "vidēji apmierināts" gadījumā, ja respondents atzīmējis atbilžu variantu "ne apmierināts, ne neapmierināts", un "apmierināts" gadījumā, ja respondents atzīmējis kādu no atbilžu variantiem "diezgan apmierināts" vai "l̦oti apmierināts". No visiem promocijas darba ietvaros analizētajiem respondentiem atbildi uz šo jautājumu nebija snieguši 43 (0,6\%) respondentu;

- riskanta alkohola lietošana, kura noteikta pēc respondentu atbildēm uz starptautiski izmantoto jautājumu: “Cik reizes savas dzīves laikā Tu esi apreibis/-usi no alkoholiskiem 
dzērieniem tā, ka ejot streipuḷoji, nevarēji skaidri parunāt, vēmi vai nevarēji atcerēties, kas notika?” ar atbilžu variantiem "nevienu reizi”, "1-2 reizes”, “3-5 reizes”, "6-9 reizes”, “10-19 reizes", "20-39 reizes” vai “40 un vairāk reizes”. Atbilžu varianti tika apvienoti, izveidojot trīs kategorijas - "nē", ja respondents atzīmējis atbilžu variantu "nevienu reizi", “1-2 reizes”, ja respondents atzīmējis attiecīgo atbilžu variantu, un "3 un vairāk reizes”, ja respondents atzīmējis kādu no atbilžu variantiem, kas raksturo piedzeršanos 3 un vairāk reizes dzīves laikā. ESPAD un citos pētījumos šāda veida alkohola lietošana (piedzeršanās) tiek uzskatīta par vienu no dzeršanas paradumiem, kas raksturo riskantu alkohola lietošanu (Trapencieris u. c., 2012) un šāda veida atbilžu variantu apvienošana izmantota ESPAD starptautisko datu analīzēe, nosakot piedzeršanās reižu skaita saistību ar pētītajiem psihosociālajiem main̄̄gajiem (Hibell et al., 2009). No visiem promocijas darba ietvaros analizētajiem respondentiem atbildi uz šo jautājumu nebija snieguši 85 (1,2\%) respondentu;

- ikdienas smēḳēšana, kuras noteikšanai, atbilstoši ESPAD starptautiski izmantotajam jautājumam, respondentiem bija jāatzīmē cik bieži respondents ir smēḳējis cigaretes pēdējo 30 dienu laikā ar atbilžu variantiem "nekad", "mazāk par 1 cigareti nedēḷā”, "mazāk par 1 cigareti dienā", "1-5 cigaretes dienā", "6-10 cigaretes dienā", "11-20 cigaretes dienā" vai "vairāk par 20 cigaretēm dienā". Atbilžu varianti tika dihotomizēti, izveidojot divas grupas - "jāa", kas noteikta, ja respondents atzīmējis atbilžu variantu "1-5 cigaretes dienā”, "6-10 cigaretes dienā", "11-20 cigaretes dienā" vai "vairāk par 20 cigaretēm dienā” un "nē”, kas noteikta, ja respondents atzīmējis atbilžu variantu "nekad", "mazāk par 1 cigareti nedēḷā" vai “mazāk par 1 cigareti dienā”. Šāda pieeja ikdienas smēḳētāju noteikšanā izmantota arī pētījumā, kas veikts pašnāvnieciskās uzvedības un ar to saistīto faktoru noteikšanai 17 Eiropas valstīs (Kokkevi et al., 2012), savukārt ikdienas vai regulāra smēḳēšana saistībā ar pašnāvniecisku uzvedību analizēta arī citos pētījumos (Wu et al., 2004; Peltzer and Pengpid, 2015; Mark et al., 2013). No visiem promocijas darba ietvaros analizētajiem respondentiem atbildi uz šo jautājumu nebija snieguši 13 (0,2\%) respondentu;

- narkotiku lietošana, kuras noteikšanai, atbilstoši starptautiski ESPAD izmantotajiem jautājumiem, respondentiem bija jāatzīmē cik bieži dzīves laikā respondents ir lietojis katru no sekojošām vielām - marihuāna/hašišs, amfetamīns, LSD/citi halucinogēni, kreks, kokaīns, heroīns, ekstazī vai spice ar atbilžu variantiem “nevienu reizi”, “1-2 reizes”, “3-5 reizes", “6-9 reizes”, “10-19 reizes", “20-39 reizes” vai "40 un vairāk reizes”. Atbilžu varianti tika dihotomizēti, izveidojot divas grupas - “jā”, kas noteikta, ja respondents atzīmējis kādu no atbilžu variantiem, kas raksturo faktu, ka respondents jebkuru no vielām dzīves laikā ir lietojis, un "nē", kas noteikta, ja respondents atzīmējis, ka nevienu no 
iepriekš minētajām vielām nav lietojis. Šāda pieeja konkrētu narkotisko vielu lietošanas noteikšanā izmantota ar̄̄ pētījumā, kas veikts pašnāvnieciskās uzvedības un ar to saistīto faktoru izpētē 17 Eiropas valstīs (Kokkevi et al., 2012), papildus šīm vielām, ņemot vērā vielas lietošanas aktualitāti Latvijā (Trapencieris u. c., 2012), pievienota arī narkotiskās vielas "spice" lietošana. Narkotiku lietošana dzīves laikā saistībā ar pašnāvniecisku uzvedību tiek analizēta arī citos pētījumos (Wang and Yen, 2017; Wolitzky-Taylor et al., 2010; Sharma et al., 2015; Monto, McRee and Deryck, 2018). No visiem promocijas darba ietvaros analizētajiem respondentiem atbildi uz visiem jautājumiem par darbā analizēto narkotiku lietošanu nebija snieguši $32(0,4 \%)$ respondentu.

\section{sociāldemogrāfiskie raksturlielumi:}

- dzimums - zēns vai meitene;

- vecums, kas aprēḳināts pēc respondenta sniegtās informāciju par viṇa dzimšanas gadu un mēnesi, aprēķinos ņemot vērā aptaujas veikšanas gadu un mēnesi. Tādējādi tika aprēḳināts skolēna vecums mēnesī, kurā tika veikta anketēšana, un izveidotas divas respondentu vecuma grupas 14-15 gadi un 16-17 gadi. Atbilstoši starptautiskajām rekomendācijām par pusaudzi tiek uzskatîta 10-19 gadus veca persona (WHO, 2017), kas ietver promocijas darba ietvaros pētītās vecuma grupas;

- gimenes materiālais stāvoklis, kura noteikšanai, atbilstoši ESPAD starptautiski izmantotajam jautājumam, respondentam bija jāatzīmē kāds ir viṇa ğimenes materiālais stāvoklis salīdzinājumā ar citām ǵimenēm valstī, izvēloties kādu no piedāvātajiem atbilžu variantiem - "ievērojami labāks", "labāks", "mazliet labāks", "apmēram tāds pats", "mazliet sliktāks", "sliktāks" vai "ievērojami sliktāks". Atbilžu varianti tika apvienoti, izveidojot trīs kategorijas - "sliktāks", ja respondents atzīmējis kādu no atbilžu variantiem "mazliet sliktāks", "sliktāks" vai "ievērojami sliktāks", "vidējs", ja respondents atzīmējis atbilžu variantu "apmēram tāds pats", un "labāks", ja respondents atzīmējis kādu no atbilžu variantiem "ievērojami labāks", "labāks" vai "mazliet labāks". Pētījumos noskaidrots, ka subjektīvais sociālekonomiskā statusa mērījums reprezentē arī sociālekonomisko situāciju saistīto personīgo pieredzi (Singh-Manoux, Adler and Marmot, 2003) un pusaudžu vecumā tam var būt būtiskāka sakarība ar psihoemocionālo labklājību nekā objektīvajiem sociālekonomiskā statusa mērījumiem (Sweeting and Hunt, 2014). No visiem promocijas darba ietvaros analizētajiem respondentiem atbildi uz šo jautājumu nebija snieguši 75 $(1,0 \%)$ respondentu;

Promocijas darbā izmantotos anketas jautājumus un atbilžu variantus skatīt 1. pielikumā. 


\subsection{Pētāmās populācijas raksturojums}

Balstoties uz respondenta sniegto informāciju par dzimšanas gadu un mēnesi, kā arī ņemot vērā aptaujas veikšanas gadu un mēnesi, tika aprēḳināts skolēna vecums mēnesī, kurā tika veikta anketēšana. Kopumā datu analīzē iekḷauti 7299 respondenti vecumā 14 līdz 17 gadiem - 3471 zēni un 3828 meitenes. Vidējais respondentu vecums bija 15,5 gadi (standartnovirze 0,95). Skolēnu sadalījums vecuma grupās bija sekojošs: 14-15 gadi - 3670 $(50,3 \%) ; 16-17$ gadi $-3629(49,7 \%)$.

\subsection{Statistiskā analīze}

Atbilstoši promocijas darba mērḳim un uzdevumiem veikta dzimumstratificētā analīze.

Datu analīzei izmantotas aprakstošās statistikas metodes: biežumu sadalījums, vidējo vērtību aprēķināšana un Hī kvadrāta (angl. - chi-square) tests izmantots respondentu apakšgrupu salīdzināšanai 2 × 2 škēēstabulās, savukārt, lai salīdzinātu neatkarīgās grupas, kuru skaits pārsniedz divas, izmantota procentuālo atšķirību statistiskās ticamības intervāla noteikšana, izmantojot Vilsona metodi (angl. - Wilson score interval method) (Newcombe, 1998).

Spīrmena korelācijas (angl. - Spearman correlation) koeficients izmantots, lai noteiktu korelācijas starp pētītajiem pašnāvnieciskās uzvedības veidiem, kā arī kā pirmais solis kolinearitātes (angl. - collinearity) pārbaudē starp neatkarīgajiem mainīgajiem daudzfaktoru logiistiskās regresijas modeḷos.

Spīrmena korelācijas koeficientu vērtības interpretētas sekojoši: 0,00 līdz 0,29 nenozīmīga korelācija, 0,30 līdz 0,49 - vāja korelācija, 0,50 līdz 0,69 - vidēja korelācija, 0,70 līdz 0,89 - augsta korelācija un 0,90 līdz 1,00 - l,oti augsta korelācija (Hinkle, Wiersma and Jurs, 2003).

Lai noteiktu asociāciju starp atkarīgo un neatkarīgo pazīmi, izmantots izredžu attiecību aprēķins (angl. - odds ratio). Izredžu attiecība norāda uz pētījuma atkarīgās pazīmes izredzēm, pētījuma neatkarīgajai pazīmei mainoties par vienu vienību. Ja OR > 1 - pētījuma neatkarīgā main̄̄gā pazīme atkarīgā main̄̄gā izredzes palielina, bet, ja OR $<1$, - samazina.

Daudzfaktoru logistiskās regresijas modeḷos analizēta dažādu faktoru saistība ar pusaudžu pašnāvniecisko uzvedību dzimumu grupās. Katram pašnāvnieciskās uzvedības veidam veikta atsevišķa daudzfaktoru regresijas analīze, atsevišḳi analizējot sakarības starp 
katru pašnāvnieciskās uzvedības veidu un faktoriem trīs atsevišķās faktoru grupās - ar ǵimenes vidi saistītie faktori, ar vienaudžu vidi saistītie faktori un individuālie faktori.

Lai izvēlētos daudzfaktoru regresijas modeḷos iekḷaujamos mainīgos izmantota mērķtiecīgās atlases (angl. - purposeful selection) metode, kas paredz sākotnēji noteikt katra neatkarīgā mainīgā saistību ar iznākumu, izmantojot vienfaktora regresijas analīzi un regresijas modeḷos iekḷaut tos main̄̄gos, kuru p vērtība ir mazāka par 0,25, kā arī mainīgos, kuru ietekme vienfaktora regresijas analīzē nav statistiski ticama, bet kuri var būt potenciāli nozīmīgi izveidotā modeḷa kontekstā (Zhang, 2016).

Visos regresijas modẹ̦os iekḷautajiem neatkarīgajiem main̄̄gajiem tika veikta kolinearitātes (angl. - collinearity) pārbaude, lai noteiktu, vai starp neatkarīgajām pazīmēm nepastāv cieša savstarpējā saistība. Ciešas saistības gadījumā starp neatkarīgajiem mainīgajiem nevar izdarīt secinājumus, kurš no neatkarīgajiem mainīgajiem ietekmē atkarīgo mainīgo. Kolinearitātes pārbaudei izmantots Spīrmena korelācijas (angl. - Spearman correlation) koeficients, Tolerances tests un dispersijas inflācijas faktors (angl. - variance inflation factor) (VIF). Tolerances testa vērtība, kas ir mazāka par 0,1, un VIF vērtība, kas ir lielāka par 10, norāda uz regresijas neatkarīgo mainīgo kolinearitāti (Field, 2013).

Visiem statistiskajiem testiem noteikts būtiskuma līmenis (p) 0,05 un rezultāti atzīti par statistiski nozīmīgiem, ja p vērtība bija mazāka par iepriekš minēto būtiskuma līmeni.

Datu analīzei izmantotas datorprogrammas MS Excel un IBM SPSS. 


\section{REZULTĀTI}

\subsection{Pašnāvnieciskā uzvedība sociāldemogrāfiskajās grupās}

Nodaḷā analizēta pusaudža pašnāvnieciskās uzvedības izplatība atkarībā no respondenta dzimuma, vecuma un respondenta ǵimenes materiālā stāvokḷa. Pētāmās populācijas sadalījums dzimuma grupās aprakstīts nodaḷā 2.1. un 2.3. nodaḷās, savukārt respondentu sadalījums pēc ǵimenes materiālā stāvokḷa ir sekojošs: 8,8\% $(\mathrm{n}=632)$ respondentu, no kuriem 42,2\% $(\mathrm{n}=267)$ ir zēni un 57,8\% $(\mathrm{n}=365)$ - meitenes norādījuši, ka viṇu ǵimenes materiālais stāvoklis salīdzinājumā ar citām ğimenēm Latvijā ir sliktāks, 37,4\% $(\mathrm{n}=2703)$ respondentu, no kuriem 43,2\% $(\mathrm{n}=1167)$ ir zēni un 56,8\% $(\mathrm{n}=1536)-$ meitenes atzīmējuši, ka ğimenes materiālais stāvoklis ir vidējs, savukārt 53,8\% (n = 3889$)$ respondentu, no kuriem 51,3\% $(n=1995)$ ir zēni un 48,7\% $(n=1894)$ - meitenes norādījuši, ka viṇu gímenes materiālais stāvoklis salīdzinājumā ar citām ǵimenēm Latvijā ir labāks.

\subsubsection{Domas par pašnāvību sociāldemogrāfiskajās grupās}

Kopumā domas par pašnāvību dzīves laikā atzīmējuši 15,7\% (n = 1 142; 95\% TI = 14,9-16,6) respondentu.

Zēnu vidū domu par pašnāvību izplatība ir 11,7\% (n = 404; 95\% TI = 10,7-12,9), savukārt meiteņu vidū domu par pašnāvību izplatība ir statistiski nozīmīgi augstāka - 19,4\% $(\mathrm{n}=738 ; 95 \% \mathrm{TI}=18,1-20,7)\left(\mathrm{p}<0,001, \mathrm{df}=1, \chi^{2}=79,31\right)($ sk. 3.1. att. $)$. Vadoties pēc nesamēroto izredžu attiecību aprēḳina, meitenēm vērojamas 1,8 reizes lielākas izredzes domām par pašnāvību $(\mathrm{OR}=1,8 ; 95 \% \mathrm{TI}=1,6-2,1)$, salīizinot ar zēniem $(\mathrm{p}<0,001)$.

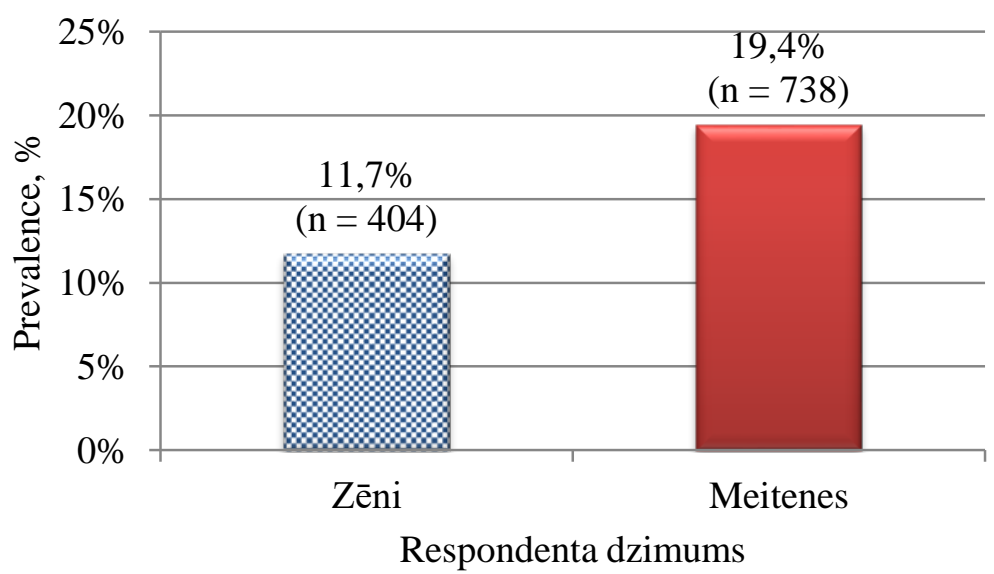

3.1. attēls. Domu par pašnāvību izplatība dzimumu grupās, \% 
Atšķirības vērojamas arī domu par pašnāvību izplatībā pusaudžu vecuma grupās gan zēniem $\left(\mathrm{p}<0,05\right.$, df $\left.=1, \chi^{2}=4,25\right)$, gan meitenēm $\left(\mathrm{p}<0,05\right.$, df $\left.=1, \chi^{2}=5,25\right)$ - vecuma grupā 16-17 gadi domu par pašnāvību izplatība abās dzimumu grupās ir augstāka (sk. 3.2. att.). Vadoties pēc nesamēroto izredžu attiecību aprēḳina, respondentu vecuma grupā 16-17 gadi ir arī statistiski nozīmīgi augstākas izredzes domām par pašnāvību, salīdzinot ar vecuma grupu 14-15 gadi - gan zēniem $(\mathrm{OR}=1,2 ; 95 \% \mathrm{TI}=1,1-1,4)(\mathrm{p}<0,05)$, gan meitenēm $(\mathrm{OR}=$ $1,2 ; 95 \% \mathrm{TI}=1,0-1,4)(\mathrm{p}<0,05)($ sk. 3.2. att. $)$.

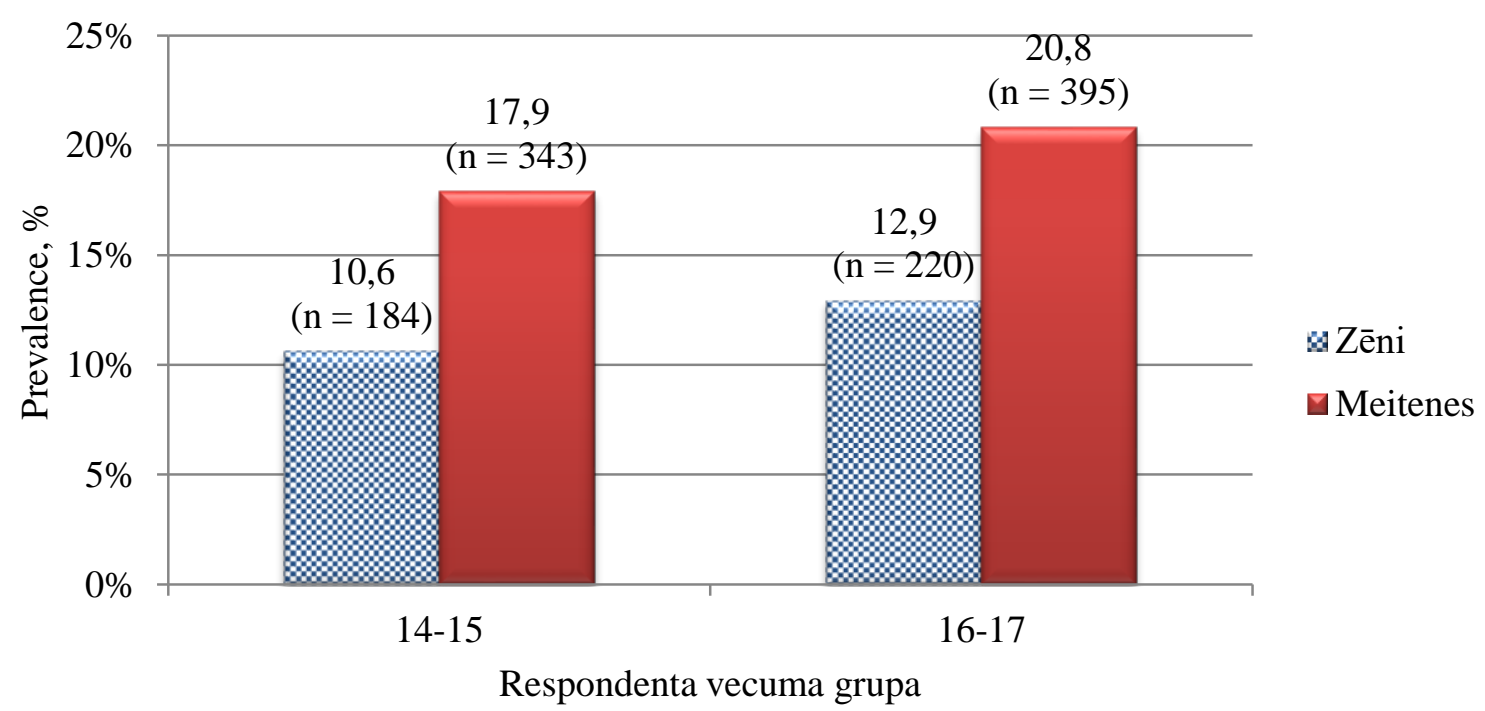

\section{2. attēls. Domu par pašnāvību izplatība vecuma grupās, \%}

Vadoties pēc procentuālo atšķirību statistiskās ticamības intervālu analīzes, dzimumu grupās pastāv statistiski nozīmīgas atškirīibas starp pusaudža domām par pašnāvību un ǵimenes materiālā stāvokḷa pašvērtējumu - gan zēnu, gan meiteņu vidū domas par pašnāvību ir statistiski nozīmīgi izplatītākas starp respondentiem, kuri ǵimenes materiālo stāvokli salīdzinājumā ar citām ǵimenēm Latvijā vērtē kā sliktāku (sk. 3.1. tab.).

Vadoties pēc nesamēroto izredžu attiecību aprēķina, abās dzimumu grupās statistiski nozīmīgi 2 reizes lielākas izredzes domām par pašnāvību vērojamas respondentiem, kuri savas gimenes materiālo stāvokli salīdzinājumā ar citām gímenēm Latvijā vērtē kā sliktāku, salīdzinot ar pusaudžiem, kuri ǵimenes materiālo stāvokli vērtē kā labāku. Atsevišķi meitenēm statistiski nozīmīgi lielākas izredzes domām par pašnāvībām vērojamas arī vidēji vērtēta ǵimenes materiālā stāvokḷa gadījumā, salīizinot ar tām meitenēm, kuras to novērtējušas kā labāku (sk. 3.1. tab.). 
Domu par pašnāvību saistība ar ğimenes materiālo stāvokli

\begin{tabular}{|l|c|c|c|c|}
\hline \multirow{2}{*}{ Domas par pašnāvību } & \multicolumn{3}{|c|}{ G̦imenes materiālais stāvoklis } \\
\cline { 2 - 5 } & $\mathrm{n}$ & Sliktāks & Vidējs & Labāks \\
\hline \multirow{3}{*}{ Zēni } & $\% 2$ & 132 & 218 \\
\cline { 2 - 5 } & $\%(95 \% \mathrm{TI})$ & $19,8(15,4-25,0)$ & $11,4(9,7-13,3)$ & $11,0(9,7-12,5)$ \\
\cline { 2 - 5 } & OR (95\% TI) & $2,0(1,4-2,8)^{* *}$ & $1,0(0,8-1,3)^{\mathrm{NS}}$ & 1,0 \\
\hline \multirow{3}{*}{ Meitenes } & $\mathrm{n}$ & 112 & 301 & 315 \\
\cline { 2 - 5 } & $\%(95 \% \mathrm{TI})$ & $30,9(26,4-35,9)$ & $19,7(17,7-21,7)$ & $16,7(15,1-18,5)$ \\
\cline { 2 - 5 } & OR (95\% TI) & $2,2(1,7-2,9)^{* *}$ & $1,2(1,0-1,4)^{*}$ & 1,0 \\
\hline
\end{tabular}

$* \mathrm{p}<0,05 ; * * \mathrm{p}<0,001 ;{ }^{\mathrm{NS}} \mathrm{p}>0,25$

\subsubsection{Pašnāvības mēgeinājumi sociāldemogrāfiskajās grupās}

Kopumā pašnāvības mēginājumu dzīves laikā atzīmējuši 8,2\% (n = 594; 95\% TI = 7,68,8) respondentu.

Vērojamas statistiski nozīmīgas atšķirības pašnāvības mēg̣inājumu izplatībā pusaudžu dzimumu grupās $\left(\mathrm{p}<0,05\right.$, df $\left.=1, \chi^{2}=43,65\right)$ - meiteṇu vidū šis īpatsvars ir augstāks $10,2 \%(\mathrm{n}=389 ; 95 \% \mathrm{TI}=9,3-11,2)$ nekā zēniem $-5,9 \%(\mathrm{n}=205 ; 95 \% \mathrm{TI}=5,2-6,8)($ sk. 3.3 . att.).

Vadoties pēc nesamēroto izredžu attiecību aprēķina, meitenēm vērojamas 1,8 reizes lielākas izredzes pašnāvības mēǵinājumam $(\mathrm{OR}=1,8 ; 95 \% \mathrm{TI}=1,5-2,1)$, salīdzinot ar zēniem $(\mathrm{p}<0,001)$.

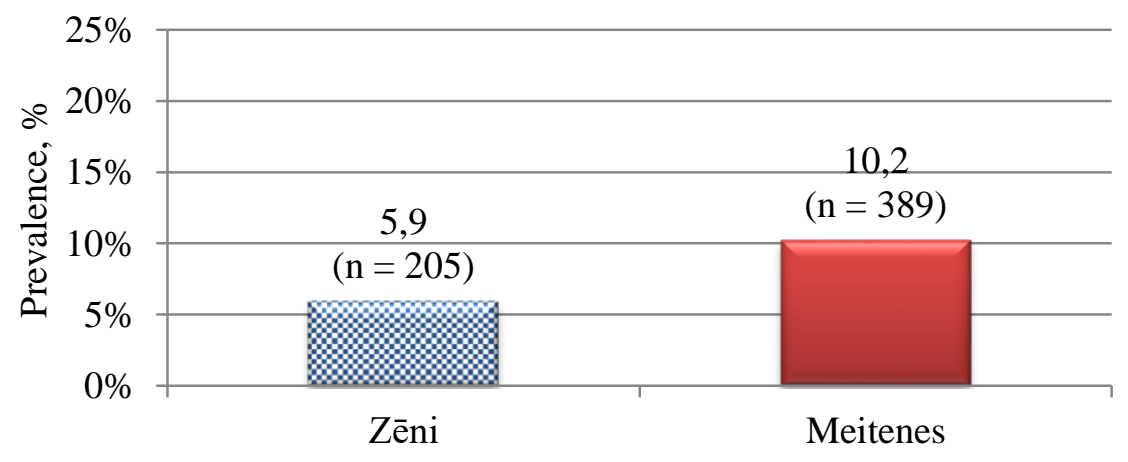

Respondenta dzimums

3.3. attēls. Pašnāvības mēgeinājumu prevalence dzimumu grupās, \% 
Atšķirībā no domām par pašnāvību, pašnāvības mēǵinājumu izplatībā netika konstatētas statistiski nozīmīgas atšķirības pusaudžu vecuma grupās - ne zēniem (p > 0,05, df $\left.=1, \chi^{2}=0,77\right)$ ne meitenēm $\left(\mathrm{p}>0,05, \mathrm{df}=1, \chi^{2}=0,15\right)$ (sk. 3.4. att.).

Arī nesamēroto izredžu aprēḳins neuzrāda statistiski nozīmīgi lielākas izredzes pašnāvības mēginājumam nevienā no vecuma grupām ne zēniem $(\mathrm{OR}=1,0 ; 95 \% \mathrm{TI}=0,8$ $1,3)(\mathrm{p}>0,25)$, ne meitenēm $(\mathrm{OR}=1,0 ; 95 \% \mathrm{TI}=0,8-1,2)(\mathrm{p}>0,25)$.

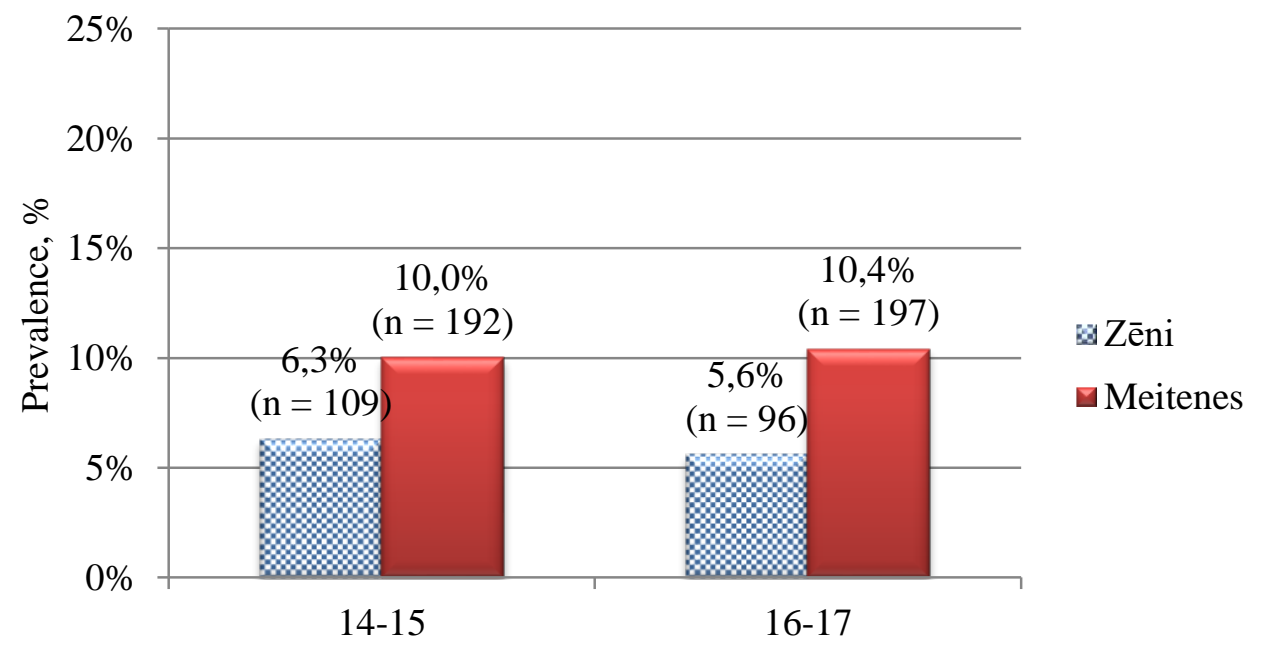

Respondenta vecuma grupa

\section{4. attēls. Pašnāvības mēğinājumu prevalence vecuma grupās, \%}

Vadoties pēc procentuālo atšķirību statistiskās ticamības intervālu analīzes, meiteṇu vidū pašnāvības mēǵinājumi ir statistiski nozīmīgi izplatītāki starp respondentiem, kuri gimenes materiālo stāvokli salīdzinājumā ar citām ğimenēm Latvijā vērtē kā sliktāku. Zēnu vidū atšķirības pašnāvības mēgininājumu izplatībā gímenes materiālā stāvokḷa grupās nav statistiski nozīmīgas (sk. 3.2. tab.).

Vadoties pēc nesamēroto izredžu attiecību aprēķina, meitenēm, kuras ǵimenes materiālo stāvokli salīdzinājumā ar citām ğimenēm Latvijā vērtē kā sliktāku, ir arī statistiski nozīmīgi 1,8 reizes lielākas izredzes pašnāvības mēǵinājumam, salīdzinot ar meitenēm, kuras savas ğimenes materiālo stāvokli novērtējušas kā labāku nekā citām ğimenēm Latvijā (sk. 3.2. tab.). 
Pašnāvības mēg̣inājumu saistība ar ğimenes materiālo stāvokli

\begin{tabular}{|l|c|c|c|c|}
\hline \multirow{2}{*}{ Pašnāvības mēǵinājums } & \multicolumn{3}{|c|}{ Ģimenes materiālais stāvoklis } \\
\cline { 2 - 5 } & & Sliktāks & Vidējs & Labāks \\
\hline \multirow{3}{*}{ Zēni } & $\mathrm{n}$ & 20 & 63 & 121 \\
\cline { 2 - 5 } & $\%(95 \% \mathrm{TI})$ & $7,5(4,9-11,3)$ & $5,4(4,2-6,9)$ & $6,1(5,1-7,2)$ \\
\cline { 2 - 5 } & OR (95\% TI) & $1,2(0,8-2,0)^{\mathrm{NS} *}$ & $0,9(0,6-1,2)^{\mathrm{NS}}$ & 1,0 \\
\hline \multirow{3}{*}{ Meitenes } & $\mathrm{n}$ & 57 & 151 & 176 \\
\cline { 2 - 5 } & $\%(95 \% \mathrm{TI})$ & $15,6(12,2-19,7)$ & $9,8(8,4-11,4)$ & $9,3(8,1-10,7)$ \\
\cline { 2 - 5 } & OR (95\% TI) & $1,8(1,3-2,5)^{* *}$ & $1,1(0,8-1,3)^{\mathrm{NS}}$ & 1,0 \\
\hline
\end{tabular}

** $\mathrm{p}<0,001 ;{ }^{\mathrm{NS}} \mathrm{p}<0,25 ;{ }^{\mathrm{NS}} \mathrm{p}>0,25$

\subsection{Pašnāvnieciskās uzvedības savstarpējā saistība}

No respondentiem, kuri atzīmējuši pašnāvības mēginājumu dz̄̄ves laikā, 66,5\% (n = 391; 95\% TI = 62,6-70,2) atzīmējuši arī domas par pašnāvību, savukārt no respondentiem, kuri atzīmējuši domas par pašnāvību, 34,4\% $(\mathrm{n}=391$; 95\% TI = 31,7-37,2) atzīmējuši arī pašnāvības mēǵinājumu. Korelācija starp pētītajiem pašnāvnieciskās uzvedības veidiem ir statistiski nozīmīga un Spīrmena korelācijas (angl. - Spearman correlation) koeficients 0,41 liecina, ka starp pētītajiem pašnāvnieciskās uzvedības veidiem pastāv vāja korelācija.

\subsection{Pašnāvnieciskā uzvedība un ar ğimenes vidi saistītie faktori}

Nodaḷā analizēta sekojošu ar ǵimenes vidi saistītu faktoru saistība ar pusaudža pašnāvniecisko uzvedību: nedzīvošana ar abiem bioloǵiskajiem vecākiem, vecāku emocionālais atbalsts, pašnāvnieciska pieredze gimenē, fiziska vardarbība gímenē un seksuāla uzmākšanās ǵimenē.

Kopējais respondentu sadalījums pēc gimenes struktūras ir šāds: 42,1\% (n = 3 073; 95\% TI $=41,0-43,2)$ respondentu abi bioloǵiskie vecāki nedzīvo ar respondentu vienā gimenē un 57,9\% ( $\mathrm{n}=4$ 226; 95\% TI $=56,8-59,0)$ respondentu abi bioloǵiskie vecāki dzīvo ar respondentu vienā ğimenē.

Savukārt kopējais respondentu sadalījums pēc vecāku emocionālā atbalsta pieejamības ir sekojošs: $8,6 \%(n=621 ; 95 \% \mathrm{TI}=8,0-9,2)$ respondentu mātes un/vai tēva emocionālo atbalstu var saṇemt reti/nekad, 12,5\% $(\mathrm{n}=903 ; 95 \% \mathrm{TI}=11,7-13,3)$ dažreiz, bet $78,9 \%(\mathrm{n}=5$ 712; 95\% TI = 78,0-79,9) - vienmēr/bieži.

Attiecībā uz kopējo respondentu sadalījumu pēc pašnāvnieciskas pieredzes ǵimenē situācija ir sekojoša: 9,5\% $(\mathrm{n}=689 ; 95 \% \mathrm{TI}=8,8-10,2)$ respondentu kāds no gimenes 
locekḷiem ir izdarīiis pašnāvību un/vai pašnāvības mēginājumu, savukārt 90,5\% (n = 6 589; 95\% TI $=89,8-91,2)$ respondentu šādas negatīvas pieredzes nav.

Uz jautājumu par fizisku vardarbību ǵimenē apstiprinoši atbildējuši 10,5\% ( $n=760$; $95 \% \mathrm{TI}=9,8-11,2)$ respondentu un noliedzošu atbildi snieguši 89,5\% (n = $6467 ; 95 \% \mathrm{TI}=$ 88,8-90,2) respondentu, savukārt uz jautājumu par seksuālu uzmākšanos ǵimenē apstiprinoši atbildējuši 2,2\% ( $=157$; 95\% TI = 1,9-2,5), bet noliedzošu atbildi snieguši 97,8\% ( $n=7066$; $95 \% \mathrm{TI}=97,5-98,1)$ respondentu.

Pētīto ar ǵimenes vidi saistīto faktoru izplatība dzimumu grupās redzama 3.3. tabulā.

Ar ğimenes vidi saistīto faktoru izplatība dzimumu grupās

\begin{tabular}{|c|c|c|c|}
\hline \multicolumn{2}{|c|}{ Ar gimenes vidi saistītie faktori } & Zēni & Meitenes \\
\hline \multicolumn{4}{|c|}{ Nedz̄̄vošana ar abiem biologiskajiem vecākiem } \\
\hline \multirow{2}{*}{$\mathrm{Ja}$} & $\mathrm{n}$ & 1463 & 1610 \\
\hline & $\%(95 \% \mathrm{TI})$ & $42,1(40,5-43,8)$ & $42,1(40,5-43,6)$ \\
\hline \multirow{2}{*}{$\mathrm{Ne \overline { }}$} & $\mathrm{n}$ & 2008 & 2218 \\
\hline & $\%(95 \% \mathrm{TI})$ & $57,9(56,2-59,5)$ & $57,9(56,4-59,5)$ \\
\hline \multicolumn{4}{|c|}{ Vecāku emocionālais atbalsts } \\
\hline \multirow{2}{*}{ Reti/nekad } & $\mathrm{n}$ & 286 & 335 \\
\hline & $\%(95 \% \mathrm{TI})$ & $8,3(7,4-9,3)$ & $8,8(8,0-9,8)$ \\
\hline \multirow{2}{*}{ Dažreiz } & $\mathrm{n}$ & 442 & 461 \\
\hline & $\%(95 \% \mathrm{TI})$ & $12,9(11,8-14,0)$ & $12,1(11,1-13,2)$ \\
\hline \multirow{2}{*}{ Vienmēr/bieži } & $\mathrm{n}$ & 2710 & 3002 \\
\hline & $\%(95 \% \mathrm{TI})$ & $78,8(77,4-80,2)$ & $79,0(77,7-80,3)$ \\
\hline \multicolumn{4}{|c|}{ Pašñ̄vnieciska pieredze ğimenē } \\
\hline \multirow{2}{*}{$\mathrm{Jā}$} & $\mathrm{n}$ & 287 & 402 \\
\hline & $\%(95 \% \mathrm{TI})$ & $8,3(7,4-9,3)$ & $10,5(9,6-11,5)$ \\
\hline \multirow{2}{*}{$\mathrm{Ne}$} & $\mathrm{n}$ & 3172 & 3417 \\
\hline & $\%(95 \% \mathrm{TI})$ & $91,7(90,7-92,6)$ & $89,5(88,5-90,4)$ \\
\hline \multicolumn{4}{|c|}{ Fiziska vardarbība gimenē } \\
\hline \multirow{2}{*}{$\mathrm{Ja}$} & $\mathrm{n}$ & 347 & 413 \\
\hline & $\%(95 \% \mathrm{TI})$ & $10,1(9,1-11,2)$ & $10,9(9,9-11,9)$ \\
\hline \multirow{2}{*}{$\mathrm{Ne}$} & $\mathrm{n}$ & 3082 & 3385 \\
\hline & $\%(95 \% \mathrm{TI})$ & $89,9(88,8-90,8)$ & $89,1(88,1-90,1)$ \\
\hline \multicolumn{4}{|c|}{ Seksuāla uzmākšanās ğimenē } \\
\hline \multirow{2}{*}{$\mathrm{Jā}$} & $\mathrm{n}$ & 111 & 46 \\
\hline & $\%(95 \% \mathrm{TI})$ & $3,2(2,7-3,9)$ & $1,2(0,9-1,6)$ \\
\hline \multirow{2}{*}{$\mathrm{Ne}$} & $\mathrm{n}$ & 3319 & 3747 \\
\hline & $\%(95 \% \mathrm{TI})$ & $96,8(96,1-97,3)$ & $98,8(98,4-99,1)$ \\
\hline
\end{tabular}




\subsubsection{Domas par pašnāvību un ar ğimenes vidi saistītie faktori}

Analizējot domu par pašnāvību saistību ar nedzīvošanu ar abiem biologiskajiem vecākiem, nesamēroto izredžu aprēķins liecina, ka abās dzimumu grupās statistiski nozīmīgi lielākas izredzes domām par pašnāvību ir respondentiem, kuri gimenē nedzīvo ar abiem bioloǵiskajiem vecākiem - zēniem no šādām ǵimenēm ir divas reizes lielākas izredzes domām par pašnāvību, savukārt meitenēm - 1,5 reizes lielākas izredzes domām par pašnāvību, salīdzinot ar respondentiem, kuri dz̄ivo ğimenēs ar abiem biologiiskajiem vecākiem (sk. 3.4. tab.).

3.4. tabula

Domu par pašnāvību saistība ar nedzīvošanu ar abiem bioloğiskajiem vecākiem

\begin{tabular}{|l|c|c|c|}
\hline \multicolumn{2}{|c|}{ Domas par pašnāvību } & \multicolumn{2}{|c|}{ Nedzīvo ar abiem biologiskajiem vecākiem } \\
\cline { 2 - 4 } & & $\mathrm{Jā}$ & Nē \\
\hline \multirow{3}{*}{ Zēni } & $\mathrm{n}$ & 231 & 173 \\
\cline { 2 - 4 } & $\%(95 \% \mathrm{TI})$ & $15,9(14,1-17,9)$ & $8,7(7,5-10,0)$ \\
\cline { 2 - 4 } & OR $(95 \% \mathrm{TI})$ & $2,0(1,6-2,4)^{* *}$ & 1,0 \\
\hline \multirow{3}{*}{ Meitenes } & $\mathrm{n}$ & 368 & 370 \\
\cline { 2 - 4 } & $\%(95 \% \mathrm{TI})$ & $23,0(21,0-25,1)$ & $16,8(15,3-18,4)$ \\
\cline { 2 - 4 } & OR $(95 \% \mathrm{TI})$ & $1,5(1,3-1,7)^{* *}$ & 1,0 \\
\hline
\end{tabular}

$* * \mathrm{p}<0,001$

Analizējot domu par pašnāvību saistību ar vecāku emocionālo atbalstu, nesamēroto izredžu attiecību aprēķins liecina, ka zēnu vidū līdz ar vecāku emocionālā atbalsta pieejamības samazināšanos statistiski nozīmīgi palielinās izredzes domām par pašnāvību respondentiem, kuri vecāku emocionālo atbalstu saṇem dažreiz, ir gandrīz divas reizes $(\mathrm{OR}=$ 1,8) lielākas izredzes domām par pašnāvību, savukārt zēniem, kuri emocionālo atbalstu saņem reti/nekad - vairāk kā trīs $(O R=3,3)$ reizes lielākas izredzes domām par pašnāvību, salīdzinot ar respondentiem - zēniem, kuri vecāku emocionālo atbalstu saņem vienmēr/bieži (sk. 3.5. tab.).

Arī meiteņu vidū, kuras vecāku emocionālo atbalstu saņem dažreiz vai reti/nekad ir attiecīgi 2,6 un 3,7 reizes lielākas izredzes domām par pašnāvību, salīdzinot ar meitenēm, kuras emocionālo atbalstu saṇem vienmēr/bieži (sk. 3.5. tab.). 
Domu par pašnāvību saistība ar vecāku emocionālo atbalstu

\begin{tabular}{|l|c|c|c|c|}
\hline \multirow{2}{*}{ Domas par pašnāvību } & \multicolumn{3}{|c|}{ Vecāku emocionālais atbalsts } \\
\cline { 2 - 5 } & & Reti/nekad & Dažreiz & Vienmēr/bieži \\
\hline \multirow{3}{*}{ Zēni } & $\mathrm{n}$ & 74 & 69 & 258 \\
\cline { 2 - 5 } & $\%(95 \% \mathrm{TI})$ & $26,0(21,2-31,3)$ & $15,9(12,8-19,6)$ & $9,6(8,5-10,8)$ \\
\cline { 2 - 5 } & OR (95\% TI) & $3,3(2,5-4,4)^{* *}$ & $1,8(1,3-2,4)^{* *}$ & 1,0 \\
\hline \multirow{3}{*}{ Meitenes } & $\mathrm{n}$ & 133 & 145 & 457 \\
\cline { 2 - 5 } & $\%(95 \% \mathrm{TI})$ & $39,9(34,8-45,2)$ & $31,7(27,6-36,1)$ & $15,3(14,0-16,6)$ \\
\cline { 2 - 5 } & OR (95\% TI) & $3,7(2,9-4,7)^{* *}$ & $2,6(2,1-3,2)^{* *}$ & 1,0 \\
\hline
\end{tabular}

$* * \mathrm{p}<0,001$

Analizējot domu par pašnāvību saistību ar pašnāvniecisku pieredzi ǵimenē, nesamēroto izredžu attiecību aprēḳins liecina, ka to zēnu vidū, kuriem kāds no gimenes locekḷiem ir izdarījis pašnāvību un/vai pašnāvības mēginājumu, izredzes domām par pašnāvību ir statistiski nozīmīgi 13,5 reizes augstākas, salīdzinot ar respondentiem - zēniem bez pašnāvnieciskas pieredzes ğimenē (sk. 3.6. tab.).

Arī starp meitenēm ar pašnāvniecisku pieredzi ǵimenē vērojamas statistiski nozīmīgi 3,7 reizes lielākas izredzes domām par pašnāvību, salīdzinot ar respondentiem - meitenēm bez pašnāvnieciskas pieredzes ǵimenē (sk. 3.6. tab.).

3.6. tabula

Domu par pašnāvību saistība ar pašnāvniecisku pieredzi ǵimenē

\begin{tabular}{|l|c|c|c|}
\hline \multicolumn{2}{|c|}{ Domas par pašnāvību } & \multicolumn{2}{|c|}{ Pašnāvnieciska pieredze gimenē } \\
\cline { 2 - 4 } & & Jā & Nē \\
\hline \multirow{3}{*}{ Zēni } & $\mathrm{n}$ & 152 & 250 \\
\cline { 2 - 4 } & $\%(95 \% \mathrm{TI})$ & $53,7(47,9-59,4)$ & $7,9(7,0-8,9)$ \\
\cline { 2 - 4 } & OR (95\% TI) & $13,5(10,3-17,6)^{* *}$ & 1,0 \\
\hline \multirow{3}{*}{ Meitenes } & $\mathrm{n}$ & 169 & 568 \\
\cline { 2 - 4 } & $\%(95 \% \mathrm{TI})$ & $42,6(37,8-47,5)$ & $16,7(15,4-17,9)$ \\
\cline { 2 - 4 } & OR $(95 \% \mathrm{TI})$ & $3,7(2,9-4,6)^{* *}$ & 1,0 \\
\hline
\end{tabular}

$* * \mathrm{p}<0,001$

Statistiski nozīmīgi lielākas izredzes domām par pašnāvību vērojamas arī respondentiem ar fizisku vardarbību ğimenē. Zēnu vidū respondentiem, kuri tikuši iesaistīti fiziskā vardarbībā savās mājās, kurās piedalījies arī kāds pieaugušais, vērojamas 5,6 reizes lielākas izredzes domām par pašnāvību, salīdzinot ar respondentiem bez šādas pieredzes (sk. 3.7. tab.). 
Š̀̄ sakarība vērojama arī meiteņu vidū - meitenēm, kuras pieredzējušas fizisku vardarbību gímenē, ir gandrīz četras reizes $(\mathrm{OR}=3,9)$ lielākas izredzes domām par pašnāvību salīdzinot ar meitenēm bez šādas pieredzes (sk. 3.7. tab.).

Domu par pašnāvību saistība ar fizisku vardarbību ğimenē

\begin{tabular}{|l|c|c|c|}
\hline \multicolumn{2}{|c|}{ Domas par pašnāvību } & \multicolumn{2}{c|}{ Fiziska vardarbība ğimenē } \\
\cline { 2 - 4 } & & $\mathrm{Jā}$ & $\mathrm{Ne}$ \\
\hline \multirow{3}{*}{ Zēni } & $\mathrm{n}$ & 124 & 278 \\
\cline { 2 - 4 } & $\%(95 \% \mathrm{TI})$ & $36,0(31,1-41,2)$ & $9,1(8,1-10,2)$ \\
\cline { 2 - 4 } & OR $(95 \% \mathrm{TI})$ & $5,6(4,4-7,2) * *$ & 1,0 \\
\hline \multirow{3}{*}{ Meitenes } & $\mathrm{n}$ & 178 & 553 \\
\cline { 2 - 4 } & $\%(95 \% \mathrm{TI})$ & $43,5(38,8-48,4)$ & $16,4(15,2-17,7)$ \\
\cline { 2 - 4 } & OR $(95 \% \mathrm{TI})$ & $3,9(3,2-4,9)^{* *}$ & 1,0 \\
\hline
\end{tabular}

$* * \mathrm{p}<0,001$

Nesamēroto izredžu aprēḳins liecina, ka abās dzimumu grupās pastāv statistiski nozīmīga saistība arī starp domām pašnāvību un seksuālu uzmākšanos ǵimenē - zēniem, kuri piedzīvojuši seksuālu uzmākšanos, kurā iesaistīts kāds pieaugušais ǵimenes loceklis, vērojamas 10,7 reizes lielākas izredzes domām par pašnāvību, salīdzinot ar respondentiem zēniem, kuri šāda veida seksuālu vardarbību nav piedzīvojuši (sk. 3.8. tab.).

Savukārt meitenēm piedzīvotas seksuālas uzmākšanās gadījumā vērojamas 3,4 reizes lielākas izredzes domām par pašnāvību, salīdzinot ar meitenēm, kuras seksuālu uzmākšanos ğimenē nav piedzīvojušas (sk. 3.8. tab.).

3.8. tabula

\section{Domu par pašnāvību saistība ar seksuālu uzmākšanos ğimenē}

\begin{tabular}{|c|c|c|c|}
\hline \multirow{2}{*}{\multicolumn{2}{|c|}{ Domas par pašnāvību }} & \multicolumn{2}{|c|}{ Seksuāla uzmākšanās ğimenē } \\
\hline & & Jā & $\mathrm{Nē}$ \\
\hline \multirow{3}{*}{ Zēni } & $\mathrm{n}$ & 60 & 339 \\
\hline & $\%(95 \% \mathrm{TI})$ & $55,0(45,7-65,0)$ & $10,3(9,3-11,4)$ \\
\hline & OR $(95 \% \mathrm{TI})$ & $10,7(7,2-15,8)^{* *}$ & 1,0 \\
\hline \multirow{3}{*}{ Meitenes } & $\mathrm{n}$ & 20 & 710 \\
\hline & $\%(95 \% \mathrm{TI})$ & $44,4(30,9-58,8)$ & $19,0(17,8-20,3)$ \\
\hline & OR $(95 \% \mathrm{TI})$ & $3,4(1,9-6,2)^{* *}$ & 1,0 \\
\hline
\end{tabular}

$* * \mathrm{p}<0,001$

3.5. un 3.6. attēlos redzama apkopojoša informācija par nesamērotajām, statistiski nozīmīgajām izredzēm domām par pašnāvību saistībā ar pētītajiem ar gímenes vidi saistītajiem faktoriem zēniem un meitenēm. Gan zēniem, gan meitenēm sakarības starp 
domām par pašnāvību un visiem pētītajiem ar ǵimenes vidi saistītajiem faktoriem ir statistiski nozīmīgas.

Zēnu vidū trīs salīdzinoši augstākās izredzes domām par pašnāvību vērojamas respondentiem ar pašnāvniecisku pieredzi ǵimenē $(\mathrm{OR}=13,5)$, seksuālu uzmākšanos ǵimenē $(\mathrm{OR}=10,7)$ un fizisku vardarbību ǵimenē $(\mathrm{OR}=5,6)$ (sk. 3.5. att.).

Meiteņu vidū atškirības starp izredzēm domām par pašnāvību saistībā ar pētītajiem ar ğimenes vidi saistītajiem faktoriem nav tik izteiktas kā zēniem. Skaitliski salīdzinoši augstākās izredzes domām par pašnāvību vērojamas meitenēm ar fizisku vardarbību gimenē $(\mathrm{OR}=3,9)$, pašnāvniecisku pieredzi ğimenē $(\mathrm{OR}=3,7)$ un meitenēm, kuras vecāku emocionālo atbalstu saņem reti/nekad $(\mathrm{OR}=3,7)$ (sk. 3.6. att.).

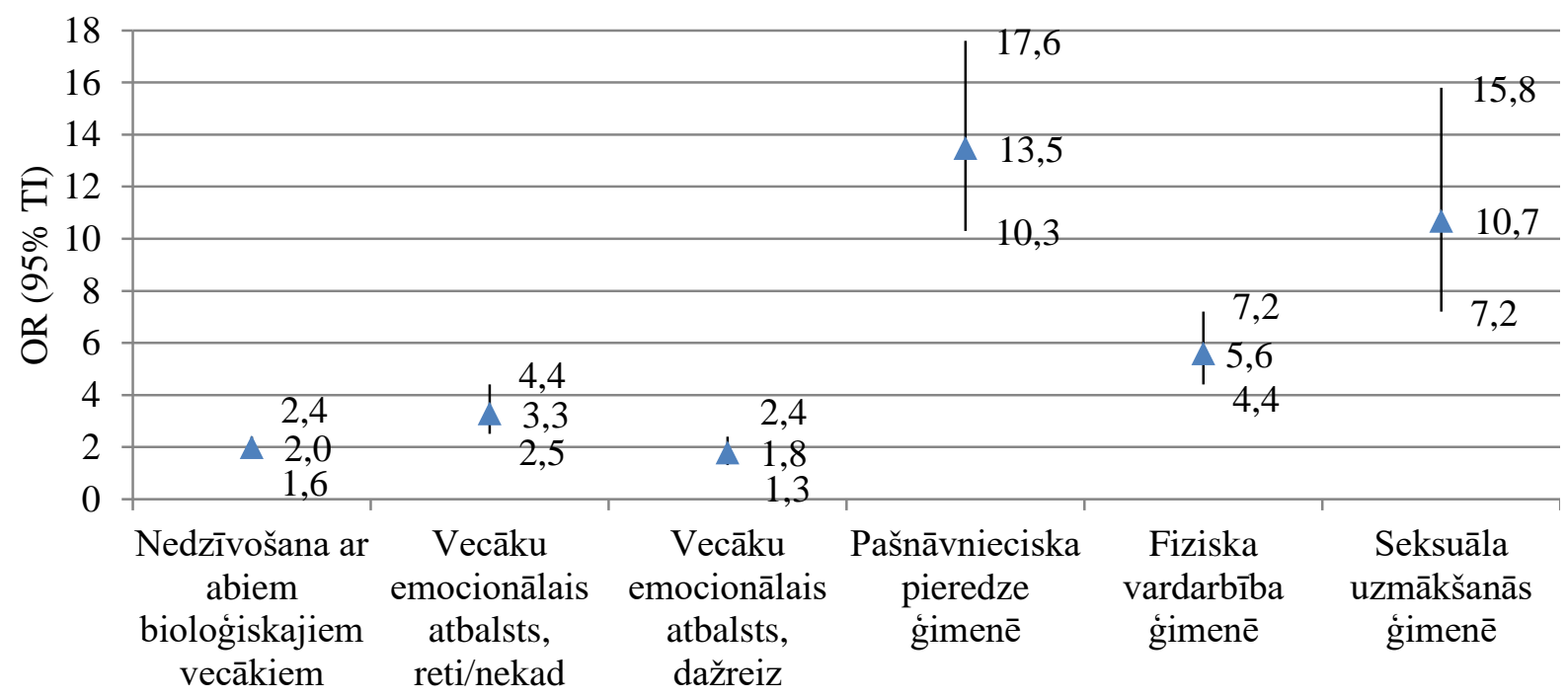

3.5. attēls. Nesamērotās izredzes domām par pašnāvību saistībā ar pētītajiem ar ǵimenes vidi saistītajiem faktoriem zēniem

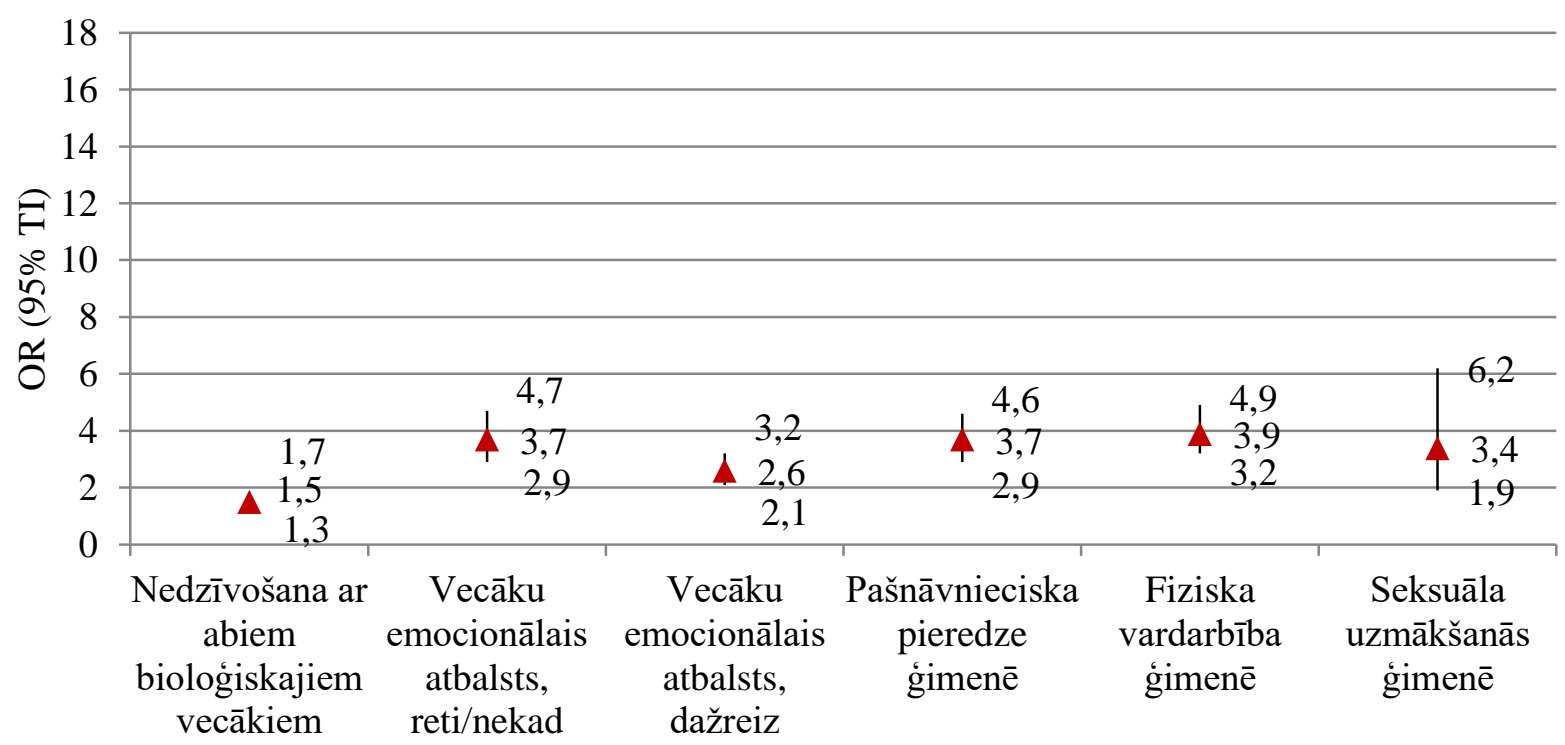

3.6. attēls. Nesamērotās izredzes domām par pašnāvību saistībā ar pētītajiem ar ğimenes vidi saistītajiem faktoriem meitenēm 
Daudzfaktoru loǵistiskās regresijas modeḷos tika analizēta pētîto ar ǵimenes vidi saistīto faktoru neatkarīgā ietekme uz pusaudža domām par pašnāvību dzimumu grupās.

Kolinearitātes pārbaude starp neatkarīgajiem mainīgajiem dzimumu grupās liecina, ka kolinearitāte netraucē izdarīt secinājumus par regresijas modeḷos iekḷauto neatkarīgo mainīgo ietekmi uz atkarīgo main̄̄go - domām par pašnāvību: zēniem Spīrmena korelācijas koeficienti norāda uz nenozīmīgu korelāciju starp neatkarīgajiem mainīgajiem, izṇemot korelāciju starp pašnāvniecisku pieredzi ǵimenē un seksuālu uzmākšanos ǵimenē $(0,38)$, kā arī fizisku vardarbību ǵimenē un seksuālu uzmākšanos ǵimenē $(0,42)$ - starp šiem mainīgajiem korelācijas ir vājas, Tolerances testa vērtības mainīgajiem nav zemākas par 0,7 un VIF vērtības nepārsniedz 1,3. Meitenēm visas korelācijas starp neatkarīgajiem mainīgajiem vērtējamas kā nenozīmīgas, Tolerances testa vērtības mainīgajiem nav zemākas par 0,9 un VIF vērtības nepārsniedz 1,1.

Sākotnēji dzimumu grupās tika veikta katra pētītā faktora samērošana ar respondenta vecumu, pēc tam modelī 1 katrs no pētītajiem faktoriem tika samērots ar respondenta vecumu un ğimenes materiālo stāvokli, savukārt modelī 2 katrs no pētītajiem faktoriem tika samērots ar respondenta vecumu, ǵimenes materiālo stāvokli un citiem pētītajiem pusaudža ǵimenes vidi raksturojošajiem faktoriem.

Pēc sākotnēji veiktās katra pētītā faktora samērošanas ar respondenta vecumu iegūtie rezultāti liecina, ka izredžu attiecību izmaiņas salīdzinot ar nesamērotajiem rādītājiem ir: $0,0 \%-0,9 \%$ zēniem un $0,0 \%-2,9 \%$ meitenēm.

Pēc modelī 1 veiktās katra pētītā faktora samērošanas ar respondenta vecumu un ǵimenes materiālo stāvokli iegūtie rezultāti liecina, ka izredžu attiecību izmaiṇas salīdzinot ar nesamērotajiem rādītājiem ir: $1,5 \%-6,1 \%$ zēniem un $5,1 \%-8,1 \%$ meitenēm un visas sakarības, kuras bija statistiski nozīmīgas vienfaktora analīzēe, saglabājas statistiski nozīmīgas.

Pēc modelī 2 veiktās pētīto faktoru savstarpējās samērošanas ar respondenta vecumu, ǵimenes materiālo stāvokli un citiem pētītajiem pusaudža gímenes vidi raksturojošajiem faktoriem, katra atsevišķāa ar ǵimenes vidi saistītā faktora neatkarīgais efekts uz domām par pašnāvību samazinās abos dzimumos (sk. 3.9. tab.).

Nedzīvošana ar abiem bioloǵiskajiem vecākiem pēc samērošanas ar respondenta vecumu un ǵimenes materiālo stāvokli zēniem domu par pašnāvību izredzes palielina gandrīz divas reizes $(\mathrm{OR}=1,9)$, bet pēc samērošanas ar respondenta vecumu, gimenes materiālo stāvokli un citiem pētītajiem ǵimenes vidi raksturojošajiem faktoriem - 1,3 reizes, salīdzinot ar zēniem, kuri dz̄ivo ar abiem biologisiskajiem vecākiem, savukārt meiteṇu vidū pēc samērošanas ar respondenta vecumu un ǵimenes materiālo stāvokli nedzīvošana ar abiem bioloǵiskajiem vecākiem domu par pašnāvību izredzes palielina 1,4 reizes, bet pēc 
samērošanas ar respondenta vecumu, ǵimenes materiālo stāvokli un citiem pētītajiem ǵimenes vidi raksturojošajiem faktoriem saistība vairs nav statistiski nozīmīga (sk. 3.9. tab.).

Reti/nekad saņemts vecāku emocionālais atbalsts pēc samērošanas ar respondenta vecumu un gimenes materiālo stāvokli zēniem domu par pašnāvību izredzes palielina 3,1 reizi, dažreiz saṇemts vecāku emocionālais atbalsts 1,7 reizes, bet pēc samērošanas ar respondenta vecumu, ǵimenes materiālo stāvokli un citiem pêtītajiem ǵimenes vidi raksturojošajiem faktoriem izredzes domām par pašnāvību ir attiecīgi 2,3 un 1,4 reizes augstākas, salīdzinot ar zēniem, kuri vecāku emocionālo atbalstu saņem vienmēr/bieži. Savukārt meiteņu vidū reti/nekad sạ̧emts vecāku emocionālais atbalsts pēc samērošanas ar respondenta vecumu un gimenes materiālo stāvokli domu par pašnāvību izredzes palielina 3,4 reizes, dažreiz saņemts vecāku emocionālais atbalsts 2,4 reizes, bet pēc samērošanas ar respondenta vecumu, ǵimenes materiālo stāvokli un citiem pētītajiem ǵimenes vidi raksturojošajiem faktoriem izredzes domām par pašnāvību ir attiecīgi 2,5 un divas reizes augstākas, salīdzinot ar meitenēm, kuras vecāku emocionālo atbalstu saṇem vienmēr/bieži (sk. 3.9. tab.).

Pašnāvnieciska pieredze gímenē pēc samērošanas ar respondenta vecumu un ǵimenes materiālo stāvokli zēniem domu par pašnāvību izredzes palielina 13,3 reizes, bet pēc samērošanas ar respondenta vecumu, ǵimenes materiālo stāvokli un citiem pētītajiem ǵimenes vidi raksturojošajiem faktoriem - 8,5 reizes, salīdzinot ar zēniem bez pašnāvnieciskas pieredzes gimenē. Meiteņu vidū pēc samērošanas ar respondenta vecumu un gimenes materiālo stāvokli pašnāvnieciska pieredze ğimenē domu par pašnāvību izredzes palielina 3,5 reizes, bet pēc samērošanas ar respondenta vecumu, ǵimenes materiālo stāvokli un citiem pētītajiem ğimenes vidi raksturojošajiem faktoriem - 2,5 reizes, salīdzinot ar meitenēm bez pašnāvnieciskas pieredzes ğimenē (sk. 3.9. tab.).

Fiziska vardarbība ǵimenē pēc samērošanas ar respondenta vecumu un ǵimenes materiālo stāvokli zēniem domu par pašnāvību izredzes palielina 5,4 reizes, bet pēc samērošanas ar respondenta vecumu, gimenes materiālo stāvokli un citiem pētītajiem gímenes vidi raksturojošajiem faktoriem, 2,5 reizes, salīdzinot ar zēniem, kuri nav tikuši iesaistīti fiziskā vardarbīiāa savās mājās, kurās piedalījies arī kāds pieaugušais. Meiteņu vidū pēc samērošanas ar respondenta vecumu un ǵimenes materiālo stāvokli fiziska vardarbība ǵimenē domu par pašnāvību izredzes palielina 3,7 reizes, bet pēc samērošanas ar respondenta vecumu, ǵimenes materiālo stāvokli un citiem pētītajiem ar ǵimenes vidi saistītajiem faktoriem - 2,4 reizes, salīdzinot ar meitenēm bez šādas pieredzes (sk. 3.9. tab.).

Seksuāla uzmākšanās ğimenē pēc samērošanas ar respondenta vecumu un ǵimenes materiālo stāvokli zēniem domu par pašnāvību izredzes palielina 10,4 reizes, salīdzinot ar 
zēniem, kuri nav piedzīvojuši seksuālu uzmākšanos, kurā iesaistīts kāds pieaugušais ğimenes loceklis, bet pēc samērošanas ar respondenta vecumu, gimenes materiālo stāvokli un citiem pētītajiem ǵimenes vidi raksturojošajiem faktoriem saistība vairs nav statistiski nozīmīga Meiteņu vidū pēc samērošanas ar respondenta vecumu un ǵimenes materiālo stāvokli seksuāla uzmākšanās ğimenē domu par pašnāvību izredzes palielina 3,2 reizes, bet pēc samērošanas respondenta vecumu, ǵimenes materiālo stāvokli un citiem pētītajiem faktoriem saistība vairs nav statistiski nozīmīga (sk. 3.9. tab.). 


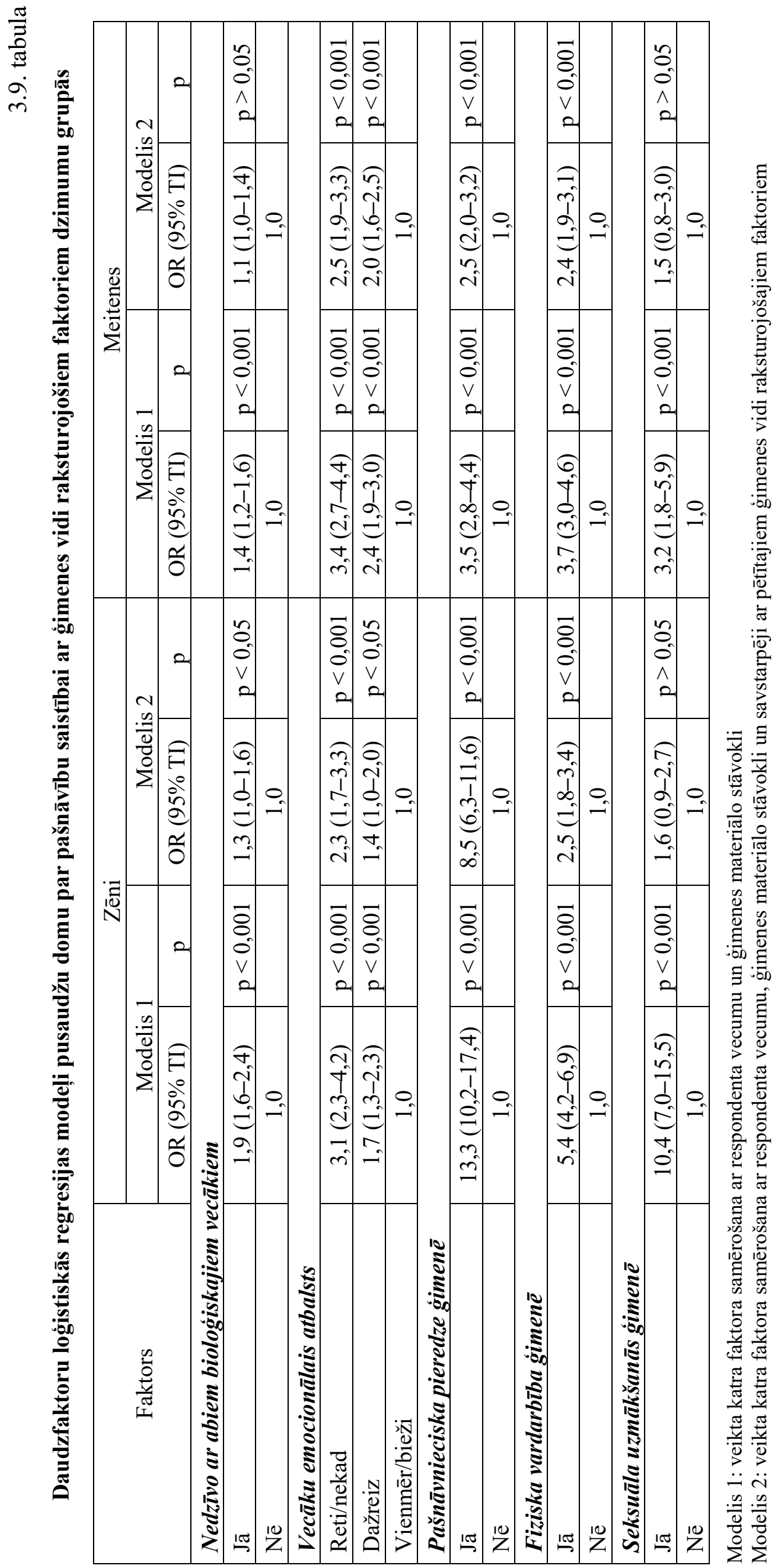




\subsubsection{Pašnāvības mēḡinājumi un ar ğimenes vidi saistītie faktori}

Analizējot saistību starp pusaudžu pašnāvības mēǵinājumiem un respondenta nedzīvošanu ar abiem biologiskajiem vecākiem, nesamēroto izredžu aprēḳins liecina, ka abās dzimumu grupās statistiski nozīmīgi lielākas izredzes arī pašnāvības mēǵinājumam ir respondentiem, kuri ğimenē nedzīvo ar abiem biologiskajiem vecākiem - zēniem no šādām ǵimenēm ir 3,1 reizi lielākas izredzes pašnāvības mēǵinājumam, savukārt meitenēm - gandrīz divas reizes $(\mathrm{OR}=1,9)$ lielākas izredzes pašnāvības mēǵinājumam, salīdzinot ar respondentiem, kuri dzīvo gimenēs ar abiem biologiskajiem vecākiem (sk. 3.10. tab.).

3.10. tabula

Pašnāvības mēḡinājumu saistība ar nedzīvošanu ar abiem bioloğiskajiem vecākiem

\begin{tabular}{|l|c|c|c|}
\hline \multicolumn{2}{|c|}{ Pašnāvības mēgeinājums } & \multicolumn{2}{|c|}{ Nedzīvo ar abiem biologiskajiem vecākiem } \\
\cline { 2 - 4 } & & Jā & Nē \\
\hline \multirow{3}{*}{ Zēni } & $\mathrm{n}$ & 139 & 66 \\
\cline { 2 - 4 } & $\%(95 \% \mathrm{TI})$ & $9,6(8,1-11,2)$ & $3,3(2,6-4,2)$ \\
\cline { 2 - 4 } & OR (95\% TI) & $3,1(2,3-4,2)^{* *}$ & 1,0 \\
\hline \multirow{3}{*}{ Meitenes } & $\mathrm{n}$ & 218 & 171 \\
\cline { 2 - 4 } & $\%(95 \% \mathrm{TI})$ & $13,5(12,0-15,3)$ & $7,7(6,7-8,9)$ \\
\cline { 2 - 4 } & OR $(95 \% \mathrm{TI})$ & $1,9(1,5-2,3)^{* *}$ & 1,0 \\
\hline
\end{tabular}

$* * \mathrm{p}<0,001$

Analizējot saistību starp pašnāvības mēǵinājumiem un vecāku emocionālo atbalstu, nesamēroto izredžu attiecību aprēḳins liecina, ka zēnu vidū statistiski nozīmīgi 3,7 reizes lielākas izredzes pašnāvības mēginājumam ir respondentiem, kuri vecāku emocionālo atbalstu saņem reti/nekad, salīdzinot ar respondentiem - zēniem, kuri vecāku emocionālo atbalstu saņem vienmēr/bieži. Atšķirīibā no domām par pašnāvību, netika novērotas statistiski lielākas izredzes pašnāvības mēgeinājumam zēniem, kuri vecāku emocionālo atbalstu saṇem dažreiz (sk. 3.11. tab.).

Savukārt meiteņu vidū, kuras vecāku emocionālo atbalstu saņem dažreiz vai reti/nekad, ir attiecīgi 2,4 un 3,6 reizes lielākas izredzes pašnāvības mēǵinājumam, salīdzinot ar meitenēm, kuras emocionālo atbalstu saņem vienmēr/bieži un šī sakarība ir statistiski nozīmīga (sk. 3.11. tab.). 
Pašnāvības mēg̣inājumu saistība ar vecāku emocionālo atbalstu

\begin{tabular}{|l|c|c|c|c|}
\hline \multicolumn{2}{|c|}{ Pašnāvības mēǵinājums } & \multicolumn{3}{c|}{ Vecāku emocionālais atbalsts } \\
\cline { 2 - 5 } & & Reti/nekad & Dažreiz & Vienmēr/bieži \\
\hline \multirow{3}{*}{ Zēni } & $\mathrm{n}$ & 45 & 29 & 128 \\
\cline { 2 - 5 } & $\%(95 \% \mathrm{TI})$ & $15,7(12,0-20,4)$ & $6,6(4,6-9,3)$ & $4,7(4,0-5,6)$ \\
\cline { 2 - 5 } & OR (95\% TI) & $3,7(2,6-5,4)^{* *}$ & $1,4(0,9-2,1)^{\mathrm{NS} *}$ & 1,0 \\
\hline \multirow{3}{*}{ Meitenes } & $\mathrm{n}$ & 77 & 78 & 232 \\
\cline { 2 - 5 } & $\%(95 \% \mathrm{TI})$ & $23,1(18,9-27,9)$ & $16,9(13,8-20,1)$ & $7,7(6,8-8,7)$ \\
\cline { 2 - 5 } & OR (95\% TI) & $3,6(2,7-4,8)^{* *}$ & $2,4(1,8-3,2)^{* *}$ & 1,0 \\
\hline
\end{tabular}

** $\mathrm{p}<0,001 ;{ }^{N S^{*}} \mathrm{p}<0,25$

Analizējot pašnāvības mēginājumu saistību ar pašnāvniecisku pieredzi gimenē, nesamēroto izredžu attiecību aprēḳins liecina, ka to zēnu vidū, kuriem kāds no ǵimenes locekḷiem ir izdarījis pašnāvību un/vai pašnāvības mēǵinājumu, izredzes pašnāvības mēg̣inājumam ir statistiski nozīmīgi 9,2 reizes augstākas, salīdzinot ar respondentiem zēniem bez pašnāvnieciskas pieredzes ğimenē (sk. 3.12. tab.).

Arī starp meitenēm ar pašnāvniecisku pieredzi ǵimenē vērojamas statistiski nozīmīgi 4,3 reizes lielākas izredzes pašnāvības mēginājumam, salīdzinot ar respondentiem - meitenēm bez pašnāvnieciskas pieredzes ğimenē (sk. 3.12. tab.).

3.12. tabula

Pašnāvības mēẹginājumu saistība ar pašnāvniecisku pieredzi ğimenē

\begin{tabular}{|l|c|c|c|}
\hline \multicolumn{2}{|c|}{ Pašnāvības mēgoinājums } & \multicolumn{2}{c|}{ Pašnāvnieciska pieredze ǵimenē } \\
\cline { 2 - 4 } & & $\mathrm{Jā}$ & $\mathrm{Ne}$ \\
\hline \multirow{3}{*}{ Zēni } & $\mathrm{n}$ & 78 & 125 \\
\cline { 2 - 4 } & $\%(95 \% \mathrm{TI})$ & $27,5(22,6-32,9)$ & $4,0(3,3-4,7)$ \\
\cline { 2 - 4 } & OR $(95 \% \mathrm{TI})$ & $9,2(6,7-12,6)^{* *}$ & 1,0 \\
\hline \multirow{3}{*}{ Meitenes } & $\mathrm{n}$ & 111 & 277 \\
\cline { 2 - 4 } & $\%(95 \% \mathrm{TI})$ & $27,8(23,6-32,3)$ & $8,1(7,2-9,1)$ \\
\cline { 2 - 4 } & OR $(95 \% \mathrm{TI})$ & $4,3(3,4-5,6)^{* *}$ & 1,0 \\
\hline
\end{tabular}

$* * \mathrm{p}<0,001$

Statistiski nozīmīgi lielākas izredzes pašnāvības mēginājumam vērojamas arī respondentiem ar fizisku vardarbību ǵimenē. Zēnu vidū respondentiem, kuri tikuši iesaistīti fiziskā vardarbībā savās mājās, kurās piedalījies arī kāds pieaugušais, vērojamas gandrīz astoṇas reizes $(\mathrm{OR}=7,8)$ lielākas izredzes pašnāvības mēǵinājumam, salīdzinot ar respondentiem bez šādas pieredzes (sk. 3.13. tab.). 
Šì sakarība vērojama arī meiteṇu vidū - meitenēm, kuras pieredzējušas fizisku vardarbību gimenē, ir 3,4 reizes lielākas izredzes pašnāvības mēǵinājumam, salīdzinot ar meitenēm bez šādas pieredzes (sk. 3.13. tab.).

3.13. tabula

Pašnāvības mēḡinājumu saistība ar fizisku vardarbību ğimenē

\begin{tabular}{|c|c|c|c|}
\hline \multirow{2}{*}{\multicolumn{2}{|c|}{ Pašnāvības mēǵinājums }} & \multicolumn{2}{|c|}{ Fiziska vardarbība ğimenē } \\
\hline & & $\mathrm{Jā}$ & $\mathrm{Ne \overline { }}$ \\
\hline \multirow{3}{*}{ Zēni } & $\mathrm{n}$ & 82 & 117 \\
\hline & $\%(95 \% \mathrm{TI})$ & $23,7(19,5-28,4)$ & $3,8(3,2-4,6)$ \\
\hline & OR $(95 \%$ TI $)$ & $7,8(5,8-10,7)^{* *}$ & 1,0 \\
\hline \multirow{3}{*}{ Meitenes } & $\mathrm{n}$ & 98 & 285 \\
\hline & $\%(95 \% \mathrm{TI})$ & $23,8(19,9-28,1)$ & $8,4(7,5-9,4)$ \\
\hline & OR $(95 \% \mathrm{TI})$ & $3,4(2,6-4,4)^{* *}$ & 1,0 \\
\hline
\end{tabular}

** $\mathrm{p}<0,001$

Nesamēroto izredžu aprēķins liecina, ka abās dzimumu grupās pastāv statistiski nozīmīga saistība arī starp pašnāvības mēǵinājumiem un seksuālu uzmākšanos ǵimenē zēniem, kuri piedzīvojuši seksuālu uzmākšanos, kurā iesaistīts kāds pieaugušais gimenes loceklis, vērojamas sešpadsmit reizes lielākas izredzes pašnāvības mēǵinājumam, salīdzinot ar respondentiem - zēniem, kuri šāda veida seksuālu vardarbību nav piedzīvojuši (sk. 3.14. tab.).

Savukārt meitenēm piedzīvotas seksuālas uzmākšanās gadījumā vērojamas 3,7 reizes lielākas izredzes pašnāvības mēg̣inājumam, salīdzinot ar meitenēm, kuras seksuālu uzmākšanos g̊imenē nav piedzīvojušas (sk. 3.14. tab.).

Pašnāvības mēgeinājumu saistība ar seksuālu uzmākšanos ğimenē

\begin{tabular}{|l|c|c|c|}
\hline \multicolumn{2}{|c|}{ Pašnāvības mēǵinājums } & \multicolumn{2}{c|}{ Seksuāla uzmākšanās ǵimenē } \\
\cline { 2 - 4 } & & $\mathrm{Jā}$ & $\mathrm{Ne}$ \\
\hline \multirow{3}{*}{ Zēni } & $\mathrm{n}$ & 47 & 150 \\
\cline { 2 - 4 } & $\%(95 \% \mathrm{TI})$ & $43,1(34,2-52,5)$ & $4,5(3,9-5,3)$ \\
\cline { 2 - 4 } & OR (95\% TI) & $16,0(10,6-24,1)^{* *}$ & 1,0 \\
\hline \multirow{3}{*}{ Meitenes } & $\mathrm{n}$ & 13 & 370 \\
\cline { 2 - 4 } & $\%(95 \% \mathrm{TI})$ & $28,9(17,7-43,4)$ & $9,9(9,0-10,9)$ \\
\cline { 2 - 4 } & OR $(95 \% \mathrm{TI})$ & $3,7(1,9-7,1)^{* *}$ & 1,0 \\
\hline
\end{tabular}

$* * \mathrm{p}<0,001$

3.7. un 3.8. attēlos redzama apkopojoša informācija par nesamērotajām, statistiski nozīmīgajām izredzēm pašnāvības mēginājumam saistībā ar pētītajiem ar gímenes vidi 
saistītajiem faktoriem zēniem un meitenēm. Kopumā gan zēniem, gan meitenēm sakarības ar visiem pētītajiem ar ğimenes vidi saistītajiem faktoriem ir statistiski nozīmīgas, taču zēnu vidū netika konstatēta statistiski nozīmīga saistība starp pašnāvības mēginājumu un vecāku emocionālā atbalsta kategoriju “dažreiz”.

Zēnu vidū salīdzinoši augstākās izredzes pašnāvības mēginājumam vērojamas respondentiem ar seksuālu uzmākšanos ǵimenē $(\mathrm{OR}=16,0)$, pašnāvniecisku pieredzi gimenē $(\mathrm{OR}=9,2)$ un fizisku vardarbību gímenē $(\mathrm{OR}=7,8)$ (sk. 3.7. att.).

Meitenēm atšķirības starp izredzēm pašnāvības mēǵinājumam starp pētītajiem ar ğimenes vidi saistītajiem faktoriem nav tik izteiktas kā zēniem. Skaitliski salīdzinoši augstākās izredzes pašnāvības mēǵinājumam vērojamas meitenēm ar pašnāvniecisku pieredzi ǵimenē $(\mathrm{OR}=4,3)$, seksuālu uzmākšanos ǵimenē $(\mathrm{OR}=3,7)$ un to meiteņu vidū, kuras vecāku emocionālo atbalstu saņem reti/nekad $(\mathrm{OR}=3,6)$ (sk. 3.8. att.).

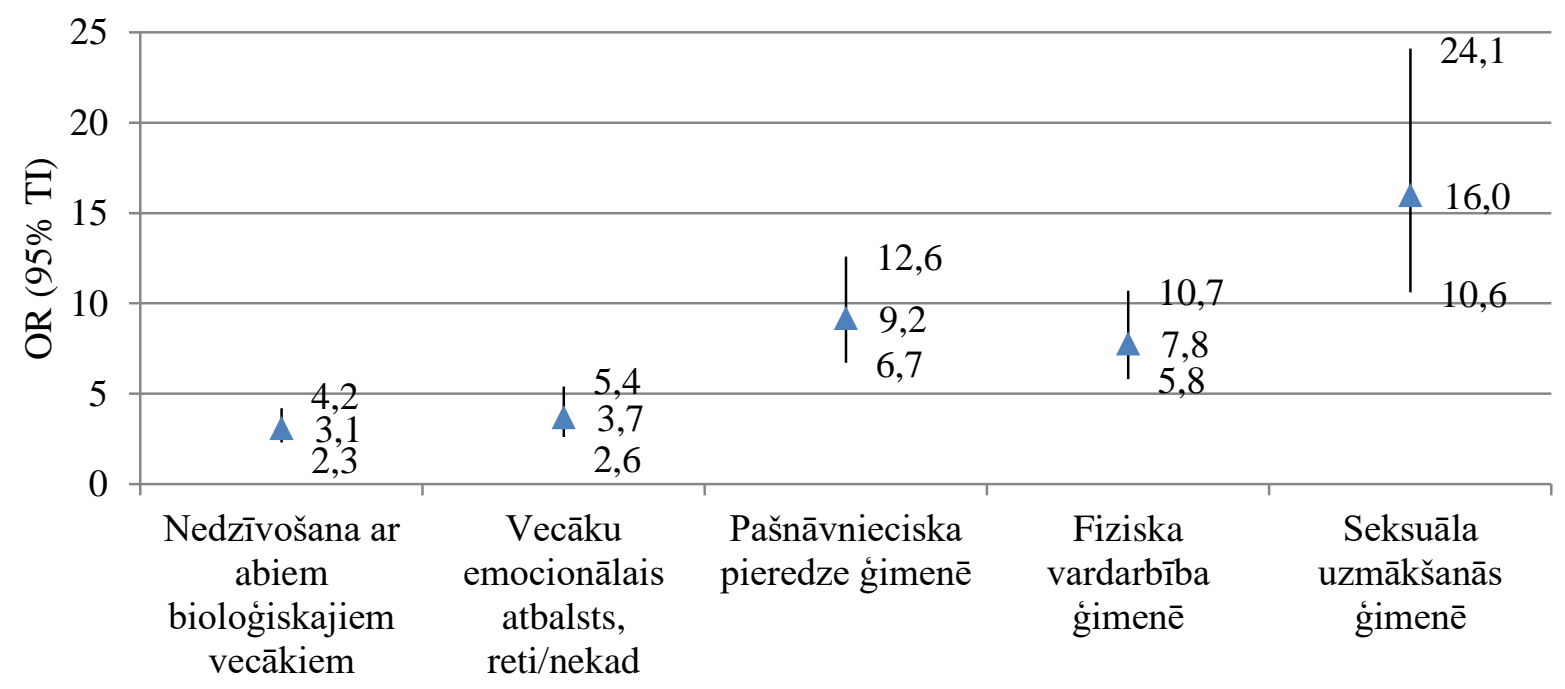

3.7. attēls. Nesamērotās izredzes pašnāvības mēgeinājumam saistībā ar pētītajiem ar gimenes vidi saistītajiem faktoriem zēniem

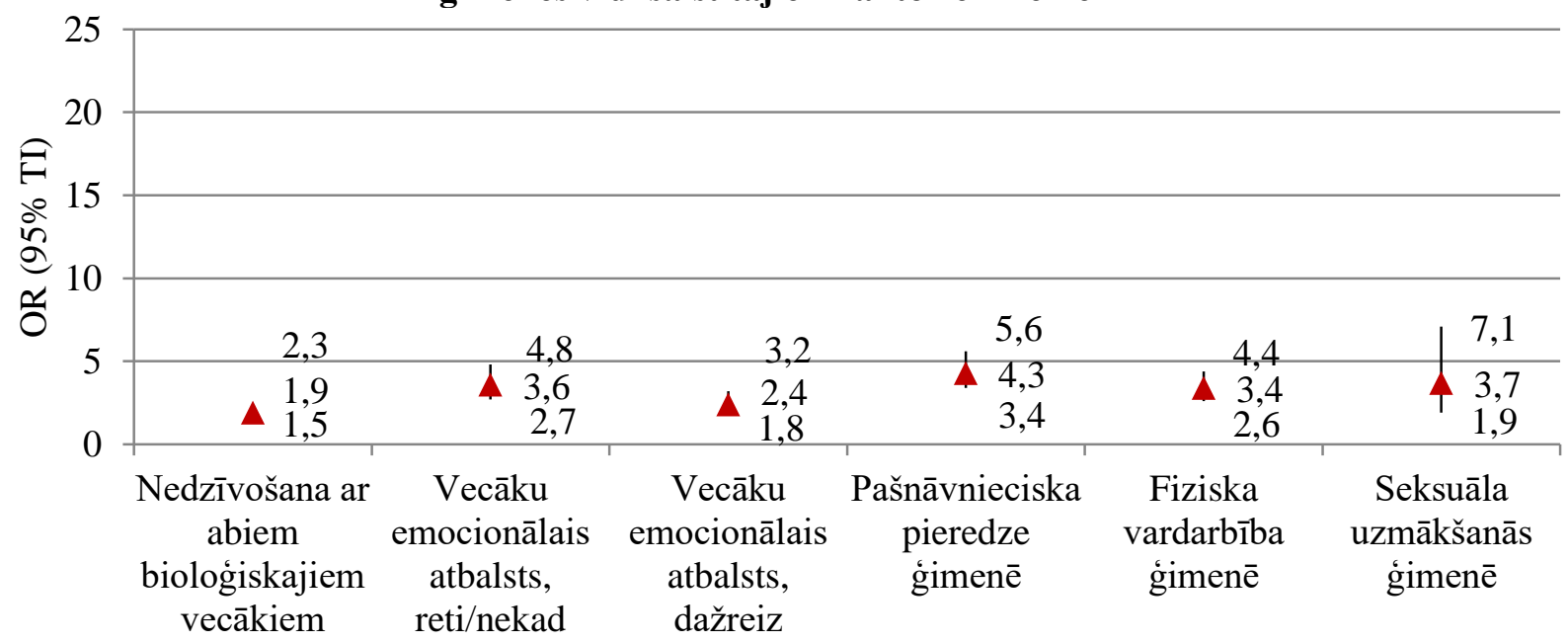

3.8. attēls. Nesamērotās izredzes pašnāvības mēgeinājumam saistībā ar pētītajiem ar gimenes vidi saistîtajiem faktoriem meitenēm 
Daudzfaktoru log̣istiskās regresijas modeḷos tika analizēta pētīto ar ǵimenes vidi saistīto faktoru neatkarīgā ietekme uz pusaudža pašnāvības mēǵinājumiem dzimumu grupās.

Kolinearitātes pārbaude starp neatkarīgajiem main̄̄gajiem dzimumu grupās liecina, ka kolinearitāte netraucē izdarīt secinājumus par regresijas modeḷos iekḷauto neatkarīgo mainīgo ietekmi uz atkarīgo mainīgo - pašnāvības mēg̣inājumu: zēniem Tolerances testa vērtības main̄̄gajiem nav zemākas par 0,7 un VIF vērtības nepārsniedz 1,3, savukārt meitenēm Tolerances testa vērtības mainīgajiem nav zemākas par 0,9 un VIF vērtības nepārsniedz 1,1. Neatkarīgo mainīgo savstarpējās korelācijas aprakstītas nodaḷā 3.3.1.

Sākotnēji tika veikta katra pētītā faktora samērošana ar respondenta vecumu, pēc tam modelī 1 katrs no pētītajiem ar ǵimenes vidi saistītajiem faktoriem tika samērots ar respondenta vecumu un ǵimenes materiālo stāvokli, savukārt modelī 2 katrs no pētītajiem faktoriem tika samērots ar respondenta vecumu, gimenes materiālo stāvokli un pētītajiem pusaudža gimenes vidi raksturojošajiem faktoriem.

Pēc sākotnēji veiktās katra pētītā ar ǵimenes vidi saistītā faktora samērošanas ar respondenta vecumu, iegūtie rezultāti liecina, ka izredžu attiecību izmaiņas pašnāvības mēginājumam, salīdzinot ar nesamērotajiem rādītājiem, ir: 0,0\%-2,7\% zēniem un 0,0\% meitenēm.

Pēc modelī 1 veiktās katra pētītā ar ǵimenes vidi saistītā faktora samērošanas ar respondenta vecumu un ǵimenes materiālo stāvokli, iegūtie rezultāti liecina, ka izredžu attiecību izmainas pašnāvības mēg̣inājumam, salīdzinot ar nesamērotajiem rādītājiem, ir: 0,0\%-5,1\% zēniem un 0,0\%-8,3\% meitenēm un visas saistības, kuras bija statistiski nozīmīgas vienfaktora analīzē, saglabājas statistiski nozīmīgas arī pēc samērošanas modelī 1 .

Pēc modelī 2 veiktās faktoru samērošanas ar respondenta vecumu, ǵimenes materiālo stāvokli un citiem pētītajiem ǵimenes vidi raksturojošajiem faktoriem, katra atsevišḳā ǵimenes vidi raksturojošā faktora neatkarīgais efekts uz pašnāvības mēǵinājumu samazinās abos dzimumos (sk. 3.15. tab.).

Nedzīvošana ar abiem bioloğiskajiem vecākiem pēc samērošanas ar respondenta vecumu un gimenes materiālo stāvokli zēniem pašnāvības mēǵinājuma izredzes palielina 3,2 reizes, bet pēc samērošanas ar respondenta vecumu, gimenes materiālo stāvokli un citiem pētītajiem ğimenes vidi raksturojošajiem faktoriem - 2,1 reizi, salīdzinot ar zēniem, kuri dz̄̄vo ar abiem biolog̣iskajiem vecākiem. Savukārt meiteṇu vidū pēc samērošanas ar respondenta vecumu un gímenes materiālo stāvokli nedzīvošana ar abiem biologiskajiem vecākiem pašnāvības mēgeinājuma izredzes palielina gandrīz divas reizes $(\mathrm{OR}=1,8)$, bet pēc samērošanas ar respondenta vecumu, ǵimenes materiālo stāvokli un citiem pētītajiem ar 
gimenes vidi saistītajiem faktoriem - 1,4 reizes, salīdzinot ar meitenēm, kuras dzīvo ar abiem biologiskajiem vecākiem (sk. 3.15. tab.).

Reti/nekad saņemts vecāku emocionālais atbalsts pēc samērošanas ar respondenta vecumu un gímenes materiālo stāvokli zēniem pašnāvības mēǵinājuma izredzes palielina 3,7 reizes, bet pēc samērošanas ar respondenta vecumu, ǵimenes materiālo stāvokli un citiem pētītajiem ǵimenes vidi raksturojošajiem faktoriem - 2,4 reizes, salīdzinot ar zēniem, kuri vecāku emocionālo atbalstu saṇem vienmēr/bieži. Zēniem pašnāvības mēǵinājuma saistība ar dažreiz saņemtu vecāku emocionālo atbalstu gan vienfaktora analīzē, gan pēc samērošanas modelī 1 un modelī 2 nav statistiski nozīmīga. Savukārt meiteņu vidū reti/nekad saṇemts vecāku emocionālais atbalsts pēc samērošanas ar respondenta vecumu un gimenes materiālo stāvokli pašnāvības mēǵinājuma izredzes palielina 3,3 reizes, dažreiz saņemts vecāku emocionālais atbalsts - 2,4 reizes, bet pēc samērošanas ar respondenta vecumu, gimenes materiālo stāvokli un citiem pētītajiem faktoriem izredzes pašnāvības mēǵinājumam ir attiecīgi 2,2 un gandrīz divas reizes $(\mathrm{OR}=1,9)$ augstākas, salīdzinot ar meitenēm, kuras vecāku emocionālo atbalstu saņem vienmēr/bieži (sk. 3.15. tab.).

Pašnāvnieciska pieredze ǵimenē pēc samērošanas ar respondenta vecumu un gimenes materiālo stāvokli zēniem pašnāvības mēǵinājuma izredzes palielina 9,3 reizes, bet pēc samērošanas ar respondenta vecumu, ǵimenes materiālo stāvokli un citiem pētītajiem ǵimenes vidi raksturojošajiem faktoriem - 3,5 reizes, salīdzinot ar zēniem bez pašnāvnieciskas pieredzes gimenē. Meiteņu vidū pēc samērošanas ar respondenta vecumu un gimenes materiālo stāvokli pašnāvnieciska pieredze gimenē pašnāvības mēǵinājuma izredzes palielina 4,2 reizes, bet pēc samērošanas ar respondenta vecumu, gimenes materiālo stāvokli un citiem pētītajiem faktoriem - trīs reizes, salīdzinot ar meitenēm bez pašnāvnieciskas pieredzes gimenē (sk. 3.15. tab.).

Fiziska vardarbība ǵimenē pēc samērošanas ar respondenta vecumu un ǵimenes materiālo stāvokli zēniem pašnāvības mēginājuma izredzes palielina 8,2 reizes, bet pēc samērošanas ar respondenta vecumu, gimenes materiālo stāvokli un citiem pētītajiem ǵimenes vidi raksturojošajiem faktoriem - trīs reizes, salīdzinot ar zēniem, kuri nav tikuši iesaistīti fiziskā vardarbībā savās mājās, kurās piedalījies arī kāds pieaugušais. Meiteṇu vidū pēc samērošanas ar respondenta vecumu un ǵimenes materiālo stāvokli fiziska vardarbība ǵimenē pašnāvības mēǵinājuma izredzes palielina 3,2 reizes, bet pēc samērošanas ar respondenta vecumu, ğimenes materiālo stāvokli un citiem pētītajiem faktoriem - gandrīz divas reizes (OR = 1,9), salīdzinot ar meitenēm bez šādas pieredzes (sk. 3.15. tab.).

Seksuāla uzmākšanās gimenē pēc samērošanas ar respondenta vecumu un ǵimenes materiālo stāvokli zēniem pašnāvības mēginājuma izredzes palielina 16,1 reizi, salīdzinot ar 
zēniem, kuri nav piedzīvojuši seksuālu uzmākšanos, kurā iesaistīts kāds pieaugušais ğimenes loceklis, bet pēc samērošanas ar respondenta vecumu, gimenes materiālo stāvokli un citiem pētītajiem ǵimenes vidi raksturojošajiem faktoriem - 3,1 reizi. Meiteņu vidū pēc samērošanas ar respondenta vecumu un gimenes materiālo stāvokli seksuāla uzmākšanās gimenē pašnāvības mēǵinājuma izredzes palielina 3,5 reizes, bet pēc samērošanas ar respondenta vecumu, ǵimenes materiālo stāvokli un citiem pētītajiem faktoriem saistība vairs nav statistiski nozīmīga (sk. 3.15. tab.). 


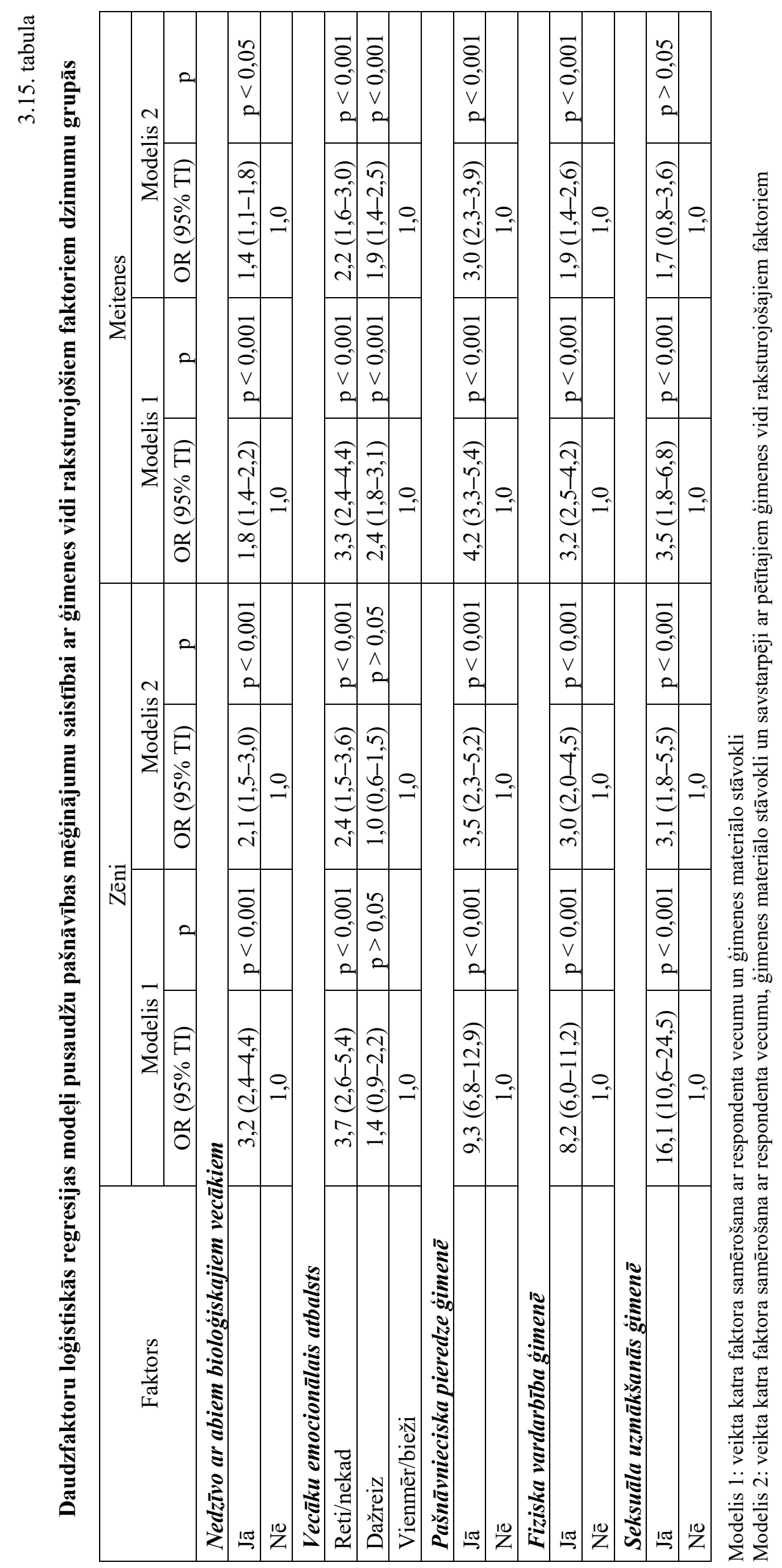




\subsection{Pašnāvnieciskā uzvedība un ar vienaudžu vidi saistītie faktori}

Nodaḷā analizēta sekojošu ar vienaudžu vidi saistītu faktoru saistība ar pusaudža pašnāvniecisko uzvedību: vienaudžu emocionālais atbalsts, pašnāvnieciska pieredze vienaudžu vidū un vienaudžu ņirgāšanās skolā.

Kopējais respondentu sadalījums pēc vienaudžu emocionālā atbalsta pieejamības ir sekojošs: 10,5\% $(\mathrm{n}=759 ; 95 \% \mathrm{TI}=9,8-11,2)$ respondentu labākā drauga/draudzenes emocionālo atbalstu var saṇemt reti/nekad, 16,3\% (n = 1 180; 95\% TI = 15,5-17,2) - dažreiz, bet 73,2\% (n = 5 305; 95\% TI = 72,2-74,2) - vienmēr/bieži.

Kopējais respondentu sadalījums pēc pašnāvnieciskas pieredzes vienaudžu vidū ir sekojošs: $22,3 \%(\mathrm{n}=1622 ; 95 \% \mathrm{TI}=21,4-23,3)$ respondentu atzina, ka kāds no draugiem vai paziṇām ir izdarījis pašnāvību un/vai pašnāvības mēginājumu, savukārt 77,7\% (n = 5 637; $95 \% \mathrm{TI}=76,7-78,6)$ respondentu šādas negatīvas pieredzes nav.

Uz jautājumu par vienaudžu ņirgāšanos skolā atbilžu sadalījums ir sekojošs: 7,9\% (n = 567; 95\% TI $=7,3-8,5)$ respondentu šādas situācijas piedzīvo vienmēr/bieži, 52,9\% (n = 3 $802 ; 95 \% \mathrm{TI}=51,8-54,1)$ respondenti - dažreiz, savukārt 39,2\% $(\mathrm{n}=2812 ; 95 \% \mathrm{TI}=38,0$ 40,3) klasesbiedru apsaukāšanu nav piedzīvojuši.

Ar vienaudžu vidi saistīto faktoru izplatība dzimumu grupās redzama 3.16. tabulā.

3.16. tabula

Ar vienaudžu vidi saistīto faktoru izplatība dzimumu grupās

\begin{tabular}{|c|c|c|c|}
\hline \multicolumn{2}{|c|}{ Ar vienaudžu vidi saistītie faktori } & Zēni & Meitenes \\
\hline \multicolumn{4}{|c|}{ Vienaudžu emocionālais atbalsts } \\
\hline \multirow{2}{*}{ Reti/nekad } & $\mathrm{n}$ & 541 & 218 \\
\hline & $\%(95 \% \mathrm{TI})$ & $15,8(14,6-17,0)$ & $5,7(5,0-6,5)$ \\
\hline \multirow{2}{*}{ Dažreiz } & $\mathrm{n}$ & 765 & 415 \\
\hline & $\%(95 \% \mathrm{TI})$ & $22,3(20,9-23,7)$ & $10,9(9,9-11,9)$ \\
\hline \multirow{2}{*}{ Vienmēr/bieži } & $\mathrm{n}$ & 2127 & 3178 \\
\hline & $\%(95 \% \mathrm{TI})$ & $62,0(60,3-63,6)$ & $83,4(82,2-84,5)$ \\
\hline \multicolumn{4}{|c|}{ Pašnāvnieciska pieredze vienauď̆u vid̄̄ } \\
\hline \multirow{2}{*}{$\mathrm{Jā}$} & $\mathrm{n}$ & 568 & 1054 \\
\hline & $\%(95 \% \mathrm{TI})$ & $16,5(15,3-17,7)$ & $27,7(26,3-29,1)$ \\
\hline \multirow{2}{*}{$\mathrm{Ne}$} & $\mathrm{n}$ & 2883 & 2754 \\
\hline & $\%(95 \% \mathrm{TI})$ & $83,5(82,3-84,7)$ & $72,3(70,9-73,7)$ \\
\hline \multicolumn{4}{|c|}{ Vienauď̆u ņirgāăšanās skolā } \\
\hline \multirow{2}{*}{ Vienmēr/bieži } & $\mathrm{n}$ & 294 & 273 \\
\hline & $\%(95 \% \mathrm{TI})$ & $8,6(7,7-9,6)$ & $7,2(6,4-8,1)$ \\
\hline \multirow{2}{*}{ Dažreiz } & $\mathrm{n}$ & 1834 & 1968 \\
\hline & $\%(95 \% \mathrm{TI})$ & $53,8(52,1-55,5)$ & $52,1(50,5-53,7)$ \\
\hline \multirow{2}{*}{ Nekad } & $\mathrm{n}$ & 1279 & 1533 \\
\hline & $\%(95 \% \mathrm{TI})$ & $37,5(35,9-39,2)$ & $40,6(39,1-42,2)$ \\
\hline
\end{tabular}




\subsubsection{Domas par pašnāvību un ar vienaudžu vidi saistītie faktori}

Analizējot domu par pašnāvību saistību ar vienaudžu emocionālo atbalstu, vadoties pēc nesamēroto izredžu attiecību aprēḳina, redzams, ka to zēnu vidū, kuri labākā drauga/draudzenes emocionālo atbalstu saņem reti/nekad, izredzes domām par pašnāvību ir statistiski nozīmīgi 1,4 reizes augstākas, salīdzinot ar respondentiem, kuri emocionālo atbalstu saṇem vienmēr/bieži (sk. 3.17. tab.).

Savukārt meiteṇu vidū statistiski nozīmīgi lielākas izredzes domām par pašnāvībām ir gan tām meitenēm, kuras labākā drauga/draudzenes emocionālo atbalstu saṇem reti/nekad $(\mathrm{OR}=1,8)$, gan tām meitenēm, kuras vienaudžu emocionālo atbalstu saṇem dažreiz $(\mathrm{OR}=$ 1,4), salīdzinot ar meitenēm, kuras emocionālo atbalstu saņem vienmēr/bieži (sk. 3.17. tab.).

3.17. tabula

Domu par pašnāvību saistība ar vienaudžu emocionālo atbalstu

\begin{tabular}{|l|c|c|c|c|}
\hline \multirow{2}{*}{ Domas par pašnāvību } & \multicolumn{3}{c|}{ Vienaudžu emocionālais atbalsts } \\
\cline { 2 - 5 } & & Reti/nekad & Dažreiz & Vienmēr/bieži \\
\hline \multirow{3}{*}{ Zēni } & $\mathrm{n}$ & 81 & 75 & 244 \\
\cline { 2 - 5 } & $\%(95 \% \mathrm{TI})$ & $15,1(12,3-18,4)$ & $9,9(8,0-12,2)$ & $11,6(10,3-13,0)$ \\
\cline { 2 - 5 } & OR (95\% TI) & $1,4(1,0-1,8)^{*}$ & $0,8(0,6-1,1)^{\mathrm{NS} *}$ & 1,0 \\
\hline \multirow{3}{*}{ Meitenes } & $\mathrm{n}$ & 63 & 99 & 574 \\
\cline { 2 - 5 } & $\%(95 \% \mathrm{TI})$ & $29,0(23,4-35,4)$ & $24,0(20,2-28,4)$ & $18,1(16,8-19,5)$ \\
\cline { 2 - 5 } & OR (95\% TI) & $1,8(1,4-2,5)^{* *}$ & $1,4(1,1-1,8)^{*}$ & 1,0 \\
\hline
\end{tabular}

$* \mathrm{p}<0,05 ; * * \mathrm{p}<0,001 ;{ }^{\mathrm{NS}} \mathrm{p}<0,25$

Analizējot domu par pašnāvību saistību ar pašnāvniecisku pieredzi vienaudžu vidū, nesamēroto izredžu attiecību aprēķins liecina, ka to zēnu vidū, kuriem kāds no draugiem vai paziņām ir izdarījis pašnāvību un/vai pašnāvības mēǵinājumu, izredzes domām par pašnāvību ir statistiski nozīmīgi gandrīz astoṇas reizes $(\mathrm{OR}=7,8)$ augstākas, salīdzinot ar respondentiem - zēniem bez pašnāvnieciskas pieredzes vienaudžu vidū (sk. 3.18. tab.).

Arī starp meitenēm ar pašnāvniecisku pieredzi vienaudžu vidū vērojamas statistiski nozīmīgi 3,6 reizes lielākas izredzes domām par pašnāvību, salīdzinot ar respondentiem meitenēm bez pašnāvnieciskas pieredzes vienaudžu vidū (sk. 3.18. tab.). 
Domu par pašnāvību saistība ar pašnāvniecisku pieredzi vienaudžu vidū

\begin{tabular}{|l|c|c|c|}
\hline \multirow{2}{*}{ Domas par pašnāvību } & \multicolumn{2}{c|}{ Pašnāvnieciska pieredze vienaudžu vidū } \\
\cline { 2 - 4 } & & $\mathrm{Ja}$ & $\mathrm{Ne}$ \\
\hline \multirow{3}{*}{ Zēni } & $\mathrm{n}$ & 204 & 194 \\
\cline { 2 - 4 } & $\%(95 \% \mathrm{TI})$ & $36,2(32,4-40,3)$ & $6,8(5,9-7,7)$ \\
\cline { 2 - 4 } & OR (95\% TI) & $7,8(6,2-9,8)^{* *}$ & 1,0 \\
\hline \multirow{3}{*}{ Meitenes } & $\mathrm{n}$ & 370 & 361 \\
\cline { 2 - 4 } & $\%(95 \% \mathrm{TI})$ & $35,3(32,5-38,2)$ & $13,1(11,9-14,4)$ \\
\cline { 2 - 4 } & OR (95\% TI) & $3,6(3,0-4,3)^{* *}$ & 1,0 \\
\hline
\end{tabular}

** $\mathrm{p}<0,001$

Analizējot domu par pašnāvību saistību ar vienaudžu ņirgāšanos skolā, redzams, ka gan zēniem, gan meitenēm nesamērotās izredzes domām par pašnāvību statistiski nozīmīgi palielinās līdz ar ņirgāšanās biežuma pieaugumu. Zēniem, kurus klasesbiedri apsaukā dažreiz, ir 1,5 reizes lielākas izredzes domām par pašnāvību, savukārt tiem respondentiem - zēniem, kurus klasesbiedri apsaukā vienmēr/bieži, vērojamas gandrīz četras reizes $(\mathrm{OR}=3,9)$ lielākas izredzes domām par pašnāvību, salīdzinot ar tiem zēniem, kuri klasesbiedru apsaukāšanu nav piedzīvojuši (sk. 3.19. tab.).

Savukārt meitenēm, kuras klasesbiedri apsaukā dažreiz, ir gandrīz divas reizes $(\mathrm{OR}=$ 1,8) lielākas izredzes domām par pašnāvību un tām meitenēm, kuras klasesbiedri apsaukā vienmēr/bieži - 3,2 reizes lielākas izredzes domām par pašnāvību, salīdzinot ar meitenēm, kuras klasesbiedru apsaukāšanu nav piedzīvojušas (sk. 3.19. tab.).

3.19. tabula

Domu par pašnāvību saistība ar vienaudžu ṇirgāšanos skolā

\begin{tabular}{|l|c|c|c|c|}
\hline \multirow{2}{*}{ Domas par pašnāvību } & \multicolumn{3}{|c|}{ Vienaudžu ņirgāšanās skolā } \\
\cline { 2 - 5 } & & Vienmēr/bieži & Dažreiz & Nekad \\
\hline \multirow{3}{*}{ Zēni } & $\mathrm{n}$ & 75 & 221 & 104 \\
\cline { 2 - 5 } & $\%(95 \% \mathrm{TI})$ & $26,0(21,2-31,3)$ & $12,1(10,7-13,7)$ & $8,2(6,8-9,8)$ \\
\cline { 2 - 5 } & OR (95\% TI) & $3,9(2,8-5,5)^{* *}$ & $1,5(1,2-2,0)^{* *}$ & 1,0 \\
\hline \multirow{3}{*}{ Meitenes } & $\mathrm{n}$ & 90 & 431 & 207 \\
\cline { 2 - 5 } & $\%(95 \% \mathrm{TI})$ & $33,2(27,9-39,0)$ & $22,0(20,2-23,9)$ & $13,6(11,9-15,4)$ \\
\cline { 2 - 5 } & OR (95\% TI) & $3,2(2,4-4,2)^{* *}$ & $1,8(1,5-2,1)^{* *}$ & 1,0 \\
\hline
\end{tabular}

$* * \mathrm{p}<0,001$

3.9. un 3.10. attēlos redzama apkopojoša informācija par nesamērotajām, statistiski nozīmīgajām izredzēm domām par pašnāvību saistībā ar pētītajiem ar vienaudžu vidi saistītajiem faktoriem zēniem un meitenēm. Kopumā gan zēniem, gan meitenēm sakarības ar 
visiem pētîtajiem vienaudžu vidi raksturojošajiem faktoriem ir statistiski nozīmīgas, taču zēnu vidū netika konstatēta statistiski nozīmīga saistība starp domām par pašnāvību un vienaudžu emocionālā atbalsta kategoriju “dažreiz".

Zēnu vidū salīdzinoši augstākās izredzes domām par pašnāvību vērojamas respondentiem ar pašnāvniecisku pieredzi vienaudžu vidū $(\mathrm{OR}=7,8)$ un vienmēr/bieži piedzīvotu vienaudžu ņirgāšanos skolā $(\mathrm{OR}=3,9)$ (sk. 3.9. att.).

Pašnāvniecisku pieredze vienaudžu vidū $(\mathrm{OR}=3,6)$ un vienmēr/bieži piedzīvota vienaudžu ņirgāšanās skolā $(\mathrm{OR}=3,2)$ visizteiktāk palielina izredzes domām par pašnāvību arī meitenēm (sk. 3.10. att.).

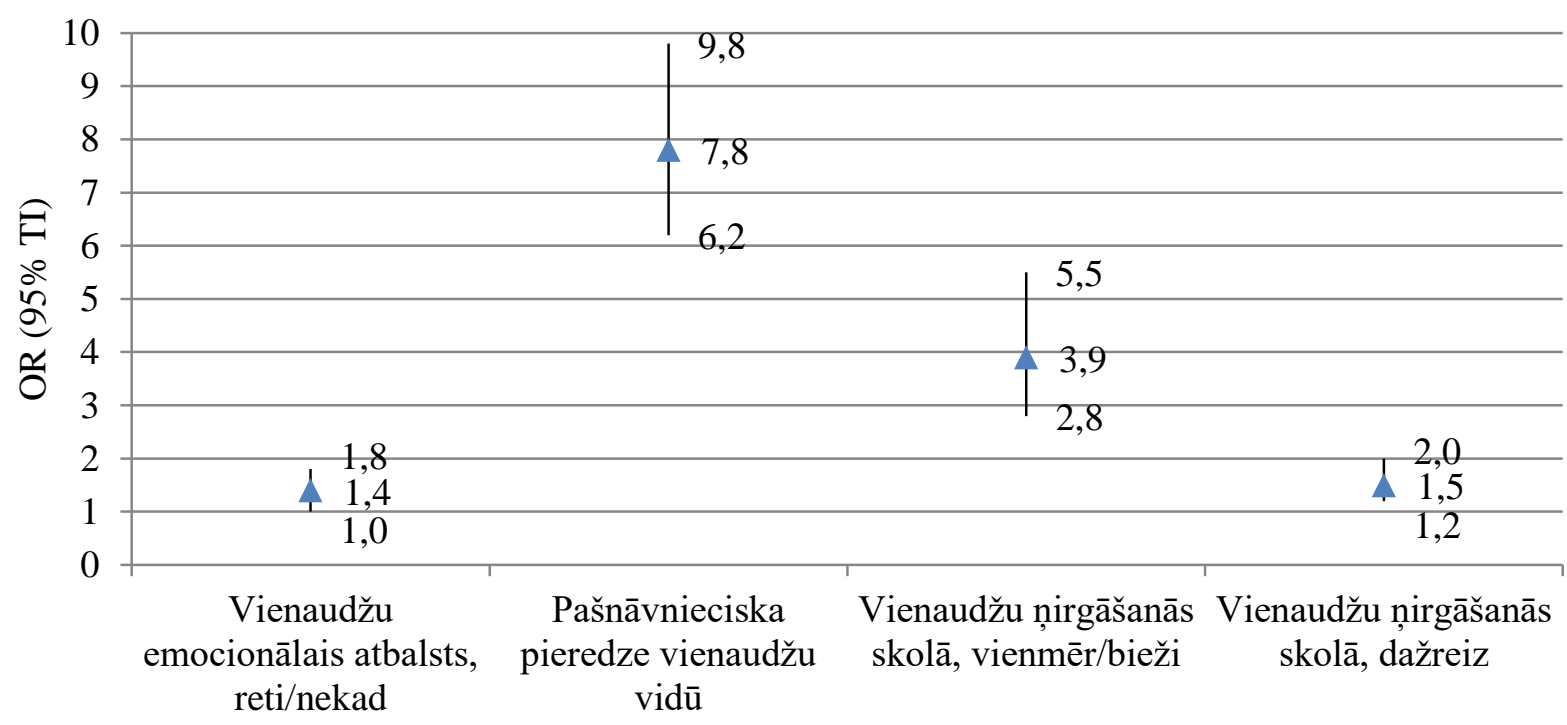

3.9. attēls. Nesamērotās izredzes domām par pašnāvību saistībā ar pētītajiem ar vienaudžu vidi saistītajiem faktoriem zēniem

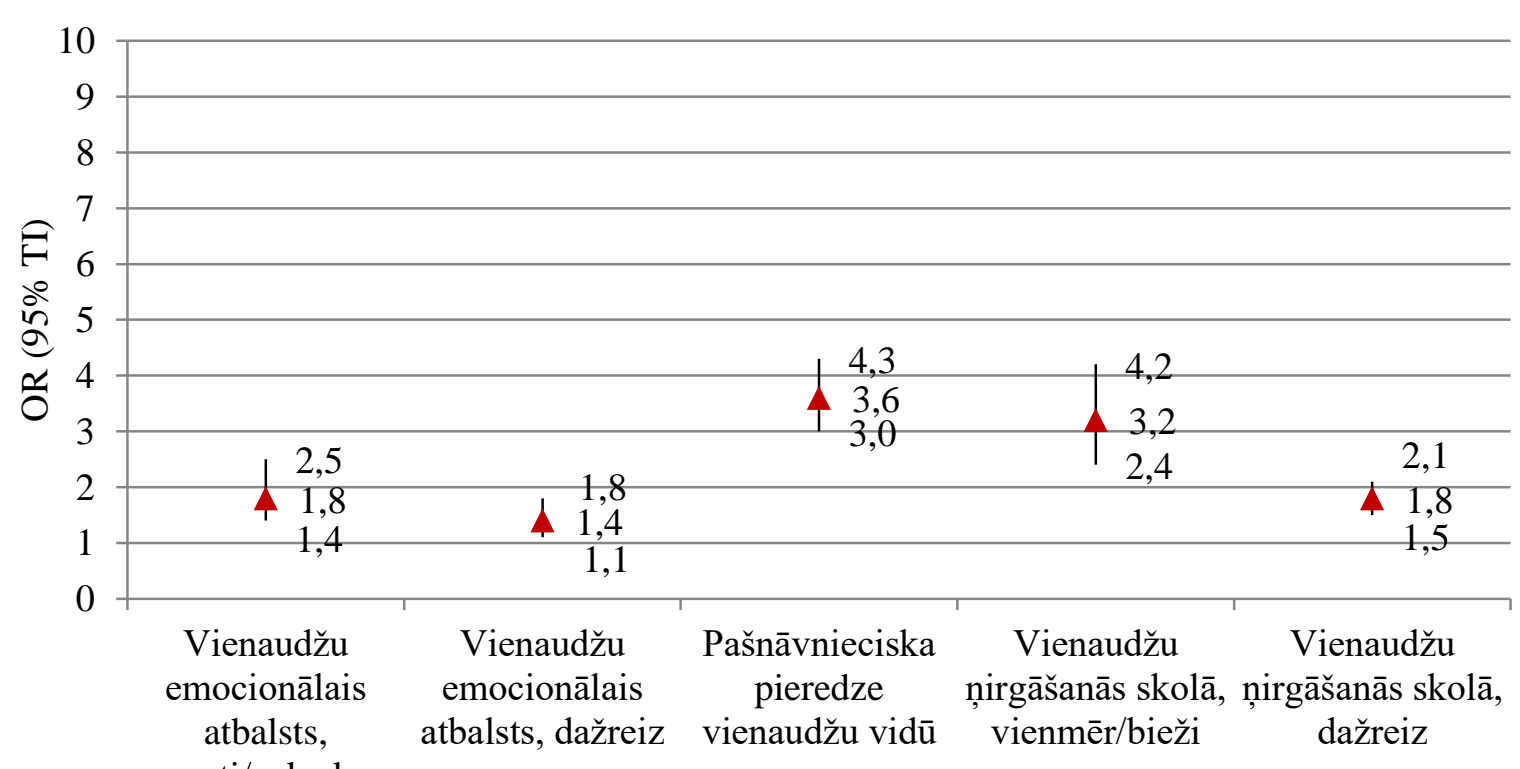

reti/nekad

3.10. attēls. Nesamērotās izredzes domām par pašnāvību saistībā ar pētītajiem ar vienaudžu vidi saistītajiem faktoriem meitenēm 
Daudzfaktoru log̣istiskās regresijas modeḷos tika analizēta pētīto ar vienaudžu vidi saistīto faktoru neatkarīgā ietekme uz pusaudža domām par pašnāvību dzimumu grupās.

Kolinearitātes pārbaude starp neatkarīgajiem main̄̄gajiem dzimumu grupās liecina, ka kolinearitāte netraucē izdarīt secinājumus par regresijas modeḷos iekḷauto neatkarīgo main̄̄go ietekmi uz atkarīgo mainīgo - domām par pašnāvību: abos dzimumos Spīrmena korelācijas koeficienti norāda uz nenozīmīgu korelāciju starp neatkarīgajiem mainīgajiem, Tolerances testa vērtības mainīgajiem nav zemākas par 0,9 un VIF vērtības nepārsniedz 1,1.

Sākotnēji tika veikta katra pētītā faktora samērošana ar respondenta vecumu, pēc tam modelī 1 katrs no pētītajiem faktoriem tika samērots ar respondenta vecumu un gimenes materiālo stāvokli, savukārt modelī 2 katrs no pētītajiem faktoriem tika samērots ar respondenta vecumu, gimenes materiālo stāvokli un pētītajiem ar vienaudžu vidi saistītajiem faktoriem.

Pēc sākotnēji veiktās katra pētītā faktora samērošanas ar respondenta vecumu iegūtie rezultāti liecina, ka izredžu attiecību izmaiņas domām par pašnāvību, salīdzinot ar nesamērotajiem rādītājiem, ir: 0,0\%-2,6\% zēniem un 0,0\%-6,2\% meitenēm.

Pēc modelī 1 veiktās katra pētītā ar vienaudžu vidi saistītā faktora samērošanas ar respondenta vecumu un gimenes materiālo stāvokli iegūtie rezultāti liecina, ka izredžu attiecību izmaiṇas domām par pašnāvību, salīdzinot ar nesamērotajiem rādītājiem, ir: 0,0\%$7,1 \%$ zēniem un $0,0 \%-5,6 \%$ meitenēm un visas saistības, kuras bija statistiski nozīmīgas vienfaktora analīzē, saglabājas statistiski nozīmīgas arī pēc samērošanas modelī 1.

Pēc modelī 2 veiktās faktoru samērošanas ar respondenta vecumu, ǵimenes materiālo stāvokli un citiem ar vienaudžu vidi saistītajiem faktoriem katra atsevišķā vienaudžu vidi raksturojošā faktora neatkarīgais efekts uz domām par pašnāvību samazinās abos dzimumos, vienai neatkarīgā mainīgā kategorijai zēniem paliek nemainīgs (sk. 3.20. tab.).

Reti/nekad saņemts vienaudžu emocionālais atbalsts pēc samērošanas ar respondenta vecumu un gimenes materiālo stāvokli zēniem domu par pašnāvību izredzes palielina 1,3 reizes, salīdzinot ar zēniem, kuri vienaudžu emocionālo atbalstu saṇem vienmēr/bieži, taču pēc samērošanas ar respondenta vecumu, gimenes materiālo stāvokli un citiem pētītajiem vienaudžu vidi raksturojošajiem faktoriem, saistība vairs nav statistiski nozīmīga. Tāpat zēniem domu par pašnāvību saistība ar dažreiz saņemtu vienaudžu emocionālo atbalstu gan vienfaktora analīzēe, gan pēc samērošanas modelī 1 un modelī 2 nav statistiski nozīmīga. Savukārt meiteņu vidū reti/nekad saṇemts vienaudžu emocionālais atbalsts pēc samērošanas ar respondenta vecumu un gimenes materiālo stāvokli domu par pašnāvību izredzes palielina 1,7 reizes, dažreiz saṇemts vienaudžu emocionālais atbalsts $-1,4$ reizes, bet pēc samērošanas ar respondenta vecumu, ǵimenes materiālo stāvokli un citiem pētītajiem faktoriem izredzes 
domām par pašnāvību ir attiecīgi 1,5 un 1,3 reizes augstākas, salīdzinot ar meitenēm, kuras vienaudžu emocionālo atbalstu saṇem vienmēr/bieži (sk. 3.20. tab.).

Pašnāvnieciska pieredze vienaudžu vidū pēc samērošanas ar respondenta vecumu un ǵimenes materiālo stāvokli zēniem domu par pašnāvību izredzes palielina gandrīz astoṇas reizes $(\mathrm{OR}=7,9)$, bet pēc samērošanas ar respondenta vecumu, ğimenes materiālo stāvokli un citiem pētītajiem vienaudžu vidi raksturojošajiem faktoriem - 7,7 reizes, salīdzinot ar zēniem bez pašnāvnieciskas pieredzes vienaudžu vidū. Meiteņu vidū pēc samērošanas ar respondenta vecumu un gimenes materiālo stāvokli pašnāvnieciska pieredze vienaudžu vidū domu par pašnāvību izredzes palielina 3,5 reizes, bet pēc samērošanas ar respondenta vecumu, ǵimenes materiālo stāvokli un citiem pētītajiem vienaudžu vidi raksturojošajiem faktoriem - 3,3 reizes, salīdzinot ar meitenēm bez pašnāvnieciskas pieredzes vienaudžu vidū (sk. 3.20. tab.).

Vienmēr/bieži piedzīvota vienaudžu ņirgāšanās skolā pēc samērošanas ar respondenta vecumu un ǵimenes materiālo stāvokli zēniem domu par pašnāvību izredzes palielina četras reizes, bet zēniem, kuri vienaudžu ņirgāšanos piedzīvojuši dažreiz - 1,5 reizes, pēc samērošanas ar respondenta vecumu, ǵimenes materiālo stāvokli un citiem pētītajiem vienaudžu vidi raksturojošajiem faktoriem izredzes domām par pašnāvību ir attiecīgi 3,7 un 1,5 reizes augstākas, salīdzinot ar zēniem, kuri vienaudžu ņirgāšanos skolā nav piedzīvojuši.

Savukārt meiteņu vidū vienmēr/bieži piedzīvota vienaudžu ņirgāšanās skolā pēc samērošanas ar respondenta vecumu un ǵimenes materiālo stāvokli domu par pašnāvību izredzes palielina 3,1 reizi, dažreiz piedzīvota vienaudžu ņirgāšanās - gandrīz divas reizes $(\mathrm{OR}=1,8)$, bet pēc samērošanas ar respondenta vecumu, ǵimenes materiālo stāvokli un citiem pētītajiem faktoriem izredzes domām par pašnāvību ir attiecīgi 2,5 un 1,6 reizes augstākas, salīdzinot ar meitenēm, kuras vienaudžu ņirgāšanos skolā nav piedzīvojušas (sk. 3.20. tab.). 


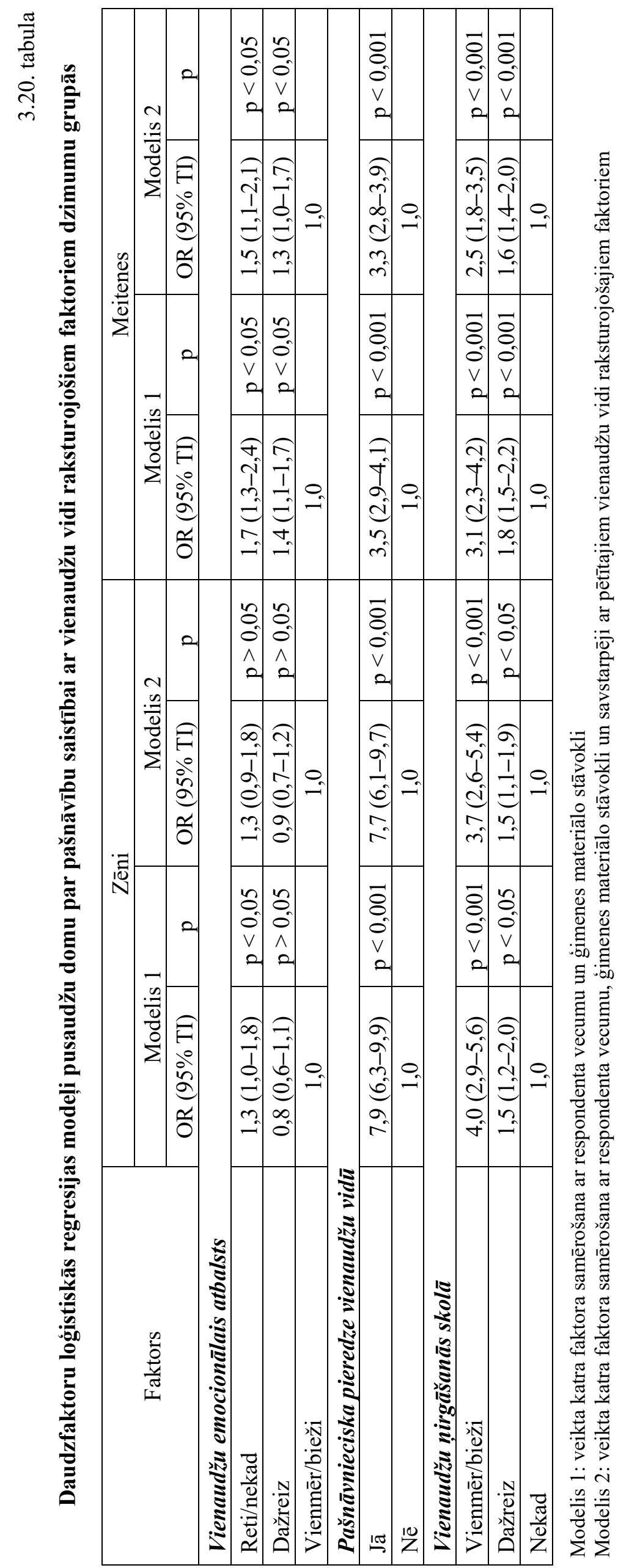




\subsubsection{Pašnāvības mēgeinājumi un ar vienaudžu vidi saistītie faktori}

Analizējot pašnāvības mēǵinājumu saistību ar vienaudžu emocionālo atbalstu, nesamēroto izredžu attiecību aprēķins liecina, ka tiem respondentiem - zēniem, kuri labākā drauga/draudzenes emocionālo atbalstu saņem dažreiz vai reti/nekad, nav statistiski lielākas izredzes pašnāvības mēginājumam, salīdzinot ar zēniem, kuri emocionālo atbalstu saṇem vienmēr/bieži (sk. 3.21. tab.).

Savukārt to meiteņu vidū, kuras labākā drauga/draudzenes emocionālo atbalstu saṇem reti/nekad, ir vērojamas statistiski nozīmīgi divas reizes lielākas izredzes pašnāvības mēǵinājumam, salīdzinot ar meitenēm, kuras emocionālo atbalstu saṇem vienmēr/bieži (sk. 3.21. tab.).

3.21. tabula

Pašnāvības mēgeinājumu saistība ar vienaudžu emocionālo atbalstu

\begin{tabular}{|l|c|c|c|c|}
\hline \multirow{2}{*}{ Pašnāvības mēǵinājums } & \multicolumn{3}{|c|}{ Vienaudžu emocionālais atbalsts } \\
\cline { 2 - 5 } & & Reti/nekad & Dažreiz & Vienmēr/bieži \\
\hline \multirow{3}{*}{ Zēni } & $\mathrm{n}$ & 40 & 41 & 121 \\
\cline { 2 - 5 } & $\%(95 \% \mathrm{TI})$ & $7,5(5,5-10,0)$ & $5,4(4,0-7,2)$ & $5,7(4,8-6,8)$ \\
\cline { 2 - 5 } & OR (95\% TI) & $1,3(0,9-1,9)^{\mathrm{NS} *}$ & $0,9(0,6-1,3)^{\mathrm{NS}}$ & 1,0 \\
\hline \multirow{3}{*}{ Meitenes } & $\mathrm{n}$ & 37 & 50 & 300 \\
\cline { 2 - 5 } & $\%(95 \% \mathrm{TI})$ & $17,0(12,6-22,5)$ & $12,1(9,3-15,6)$ & $9,5(8,5-10,5)$ \\
\cline { 2 - 5 } & OR $(95 \% \mathrm{TI})$ & $2,0(1,3-2,8)^{* *}$ & $1,3(1,0-1,8)^{\mathrm{NS} *}$ & 1,0 \\
\hline
\end{tabular}

** $\mathrm{p}<0,001 ;{ }^{\mathrm{NS}} \mathrm{p}<0,25 ;{ }^{\mathrm{NS}} \mathrm{p}>0,25$

Analizējot pusaudžu pašnāvības mēǵinājumu saistību ar pašnāvniecisku pieredzi vienaudžu vidū, nesamēroto izredžu attiecību aprēķins liecina, ka to zēnu vidū, kuriem kāds no draugiem vai paziņām ir izdarījis pašnāvību un/vai pašnāvības mēginājumu, izredzes pašnāvības mēǵinājumam ir statistiski nozīmīgi gandrīz septiņas reizes $(\mathrm{OR}=6,8)$ augstākas, salīdzinot ar respondentiem - zēniem bez pašnāvnieciskas pieredzes vienaudžu vidū (sk. 3.22. tab.).

Arī starp meitenēm ar pašnāvniecisku pieredzi vienaudžu vidū vērojamas statistiski nozīmīgi gandrīz piecas reizes $(\mathrm{OR}=4,8)$ lielākas izredzes pašnāvības mēǵinājumam, salīdzinot ar respondentiem - meitenēm bez pašnāvnieciskas pieredzes vienaudžu vidū (sk. 3.22. tab.). 
Pašnāvības mēgeinājumu saistība ar pašnāvniecisku pieredzi vienaudžu vidū

\begin{tabular}{|l|c|c|c|}
\hline \multicolumn{2}{|c|}{ Pašnāvības mēǵinājums } & \multicolumn{2}{|c|}{ Pašnāvnieciska pieredze vienaudžu vidū } \\
\cline { 2 - 4 } & & $\mathrm{Ja}$ & $\mathrm{N} \overline{\mathrm{e}}$ \\
\hline \multirow{3}{*}{ Zēni } & $\mathrm{n}$ & 106 & 95 \\
\cline { 2 - 4 } & $\%(95 \% \mathrm{TI})$ & $18,8(15,8-22,3)$ & $3,3(2,7-4,0)$ \\
\cline { 2 - 4 } & OR (95\% TI) & $6,8(5,1-9,1)^{* *}$ & 1,0 \\
\hline \multirow{3}{*}{ Meitenes } & $\mathrm{n}$ & 233 & 153 \\
\cline { 2 - 4 } & $\%(95 \% \mathrm{TI})$ & $22,1(19,7-24,8)$ & $5,6(4,8-6,5)$ \\
\cline { 2 - 4 } & OR $(95 \% \mathrm{TI})$ & $4,8(3,9-6,0)^{* *}$ & 1,0 \\
\hline
\end{tabular}

** $\mathrm{p}<0,001$

Analizējot pašnāvības mēginājumu saistību ar vienaudžu ņirgāšanos skolā redzams, ka gan zēniem, gan meitenēm nesamērotās izredzes domām par pašnāvību palielinās līdz ar ņirgāšanas biežuma pieaugumu. Zēniem, kurus klasesbiedri apsaukā dažreiz ir statistiski nozīmīgi gandrīz divas reizes $(\mathrm{OR}=1,8)$ lielākas izredzes pašnāvības mēginājumam, savukārt tiem respondentiem - zēniem, kurus klasesbiedri apsaukā vienmēr/bieži vērojamas četras reizes lielākas izredzes pašnāvības mēginājumam, salīdzinot ar tiem zēniem, kuri klasesbiedru apsaukāšanu nav piedzīvojuši (sk. 3.23. tab.).

Meitenēm, kuras klasesbiedri apsaukā dažreiz ir gandrīz divas reizes $(\mathrm{OR}=1,9)$ lielākas izredzes pašnāvības mēginājumam, savukārt tām meitenēm, kuras klasesbiedri apsaukā vienmēr/bieži - 3,1 reizi lielākas izredzes pašnāvības mēǵninājumam, salīdzinot ar meitenēm, kuras klasesbiedru apsaukāšanu nav piedzīvojušas (sk. 3.23. tab.).

3.23. tabula

Pašnāvības mēẹinājumu saistība ar vienaudžu ņirgāšanos skolā

\begin{tabular}{|l|c|c|c|c|}
\hline \multirow{2}{*}{ Pašnāvības mēǵinājums } & \multicolumn{3}{|c|}{ Vienaudžu ņirgāšanās skolā } \\
\cline { 2 - 5 } & & Vienmēr/bieži & Dažreiz & Nekad \\
\hline \multirow{3}{*}{ Zēni } & $\mathrm{n}$ & 38 & 113 & 46 \\
\cline { 2 - 5 } & $\%(95 \% \mathrm{TI})$ & $13,0(9,6-17,3)$ & $6,2(5,2-7,4)$ & $3,6(2,7-4,8)$ \\
\cline { 2 - 5 } & OR (95\% TI) & $4,0(2,5-6,2)^{* *}$ & $1,8(1,2-2,5)^{*}$ & 1,0 \\
\hline \multirow{3}{*}{ Meitenes } & $\mathrm{n}$ & 49 & 233 & 101 \\
\cline { 2 - 5 } & $\%(95 \% \mathrm{TI})$ & $17,9(13,8-23,0)$ & $11,9(10,5-13,4)$ & $6,6(5,4-7,9)$ \\
\cline { 2 - 5 } & OR (95\% TI) & $3,1(2,1-4,5)^{* *}$ & $1,9(1,5-2,4)^{* *}$ & 1,0 \\
\hline
\end{tabular}

$* \mathrm{p}<0,05 ; * * \mathrm{p}<0,001$

3.11. un 3.12. attēlos redzama apkopojoša informācija par nesamērotajām, statistiski nozīmīgajām izredzēm pašnāvības mēǵinājumam saistībā ar pētītajiem ar vienaudžu vidi saistītajiem faktoriem zēniem un meitenēm. Atšḳirībā no domām par pašnāvību, zēnu vidū 
netika konstatēta statistiski nozīmīga saistība starp pašnāvības mēǵinājumu un vienaudžu emocionālo atbalstu, savukārt meitenuu vidū netika konstatēta statistiski nozīmīga saistība starp pašnāvības mēǵinājumu un vienaudžu emocionālā atbalsta kategoriju "dažreiz".

Zēnu vidū salīdzinoši augstākās izredzes pašnāvības mēgeinājumam vērojamas respondentiem ar pašnāvniecisku pieredzi vienaudžu vidū $(O R=6,8)$ un vienmēr/bieži piedzīvotu vienaudžu ņirgāšanos skolā (OR = 4,0) (sk. 3.11. att.).

Arī meiteņu vidū skaitliski salīdzinoši augstākās izredzes pašnāvības mēǵinājumam vērojamas respondentiem ar pašnāvniecisku pieredzi vienaudžu vidū $(\mathrm{OR}=4,8)$ un vienmēr/bieži piedzīvotu vienaudžu ņirgāšanos skolā (OR = 3,1) (sk. 3.12. att.).

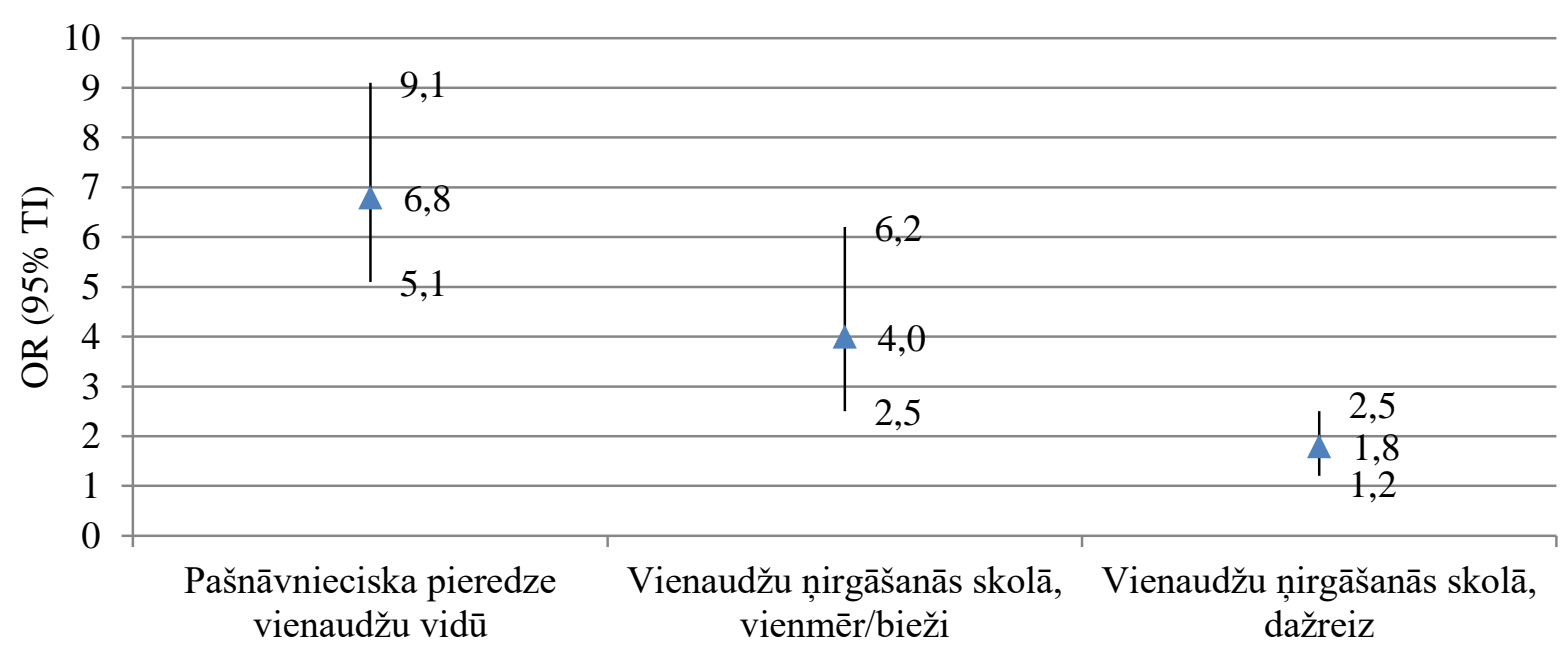

3.11. attēls. Nesamērotās izredzes pašnāvības mēǵinājumam saistībā ar pētītajiem ar vienaudžu vidi saistītajiem faktoriem zēniem

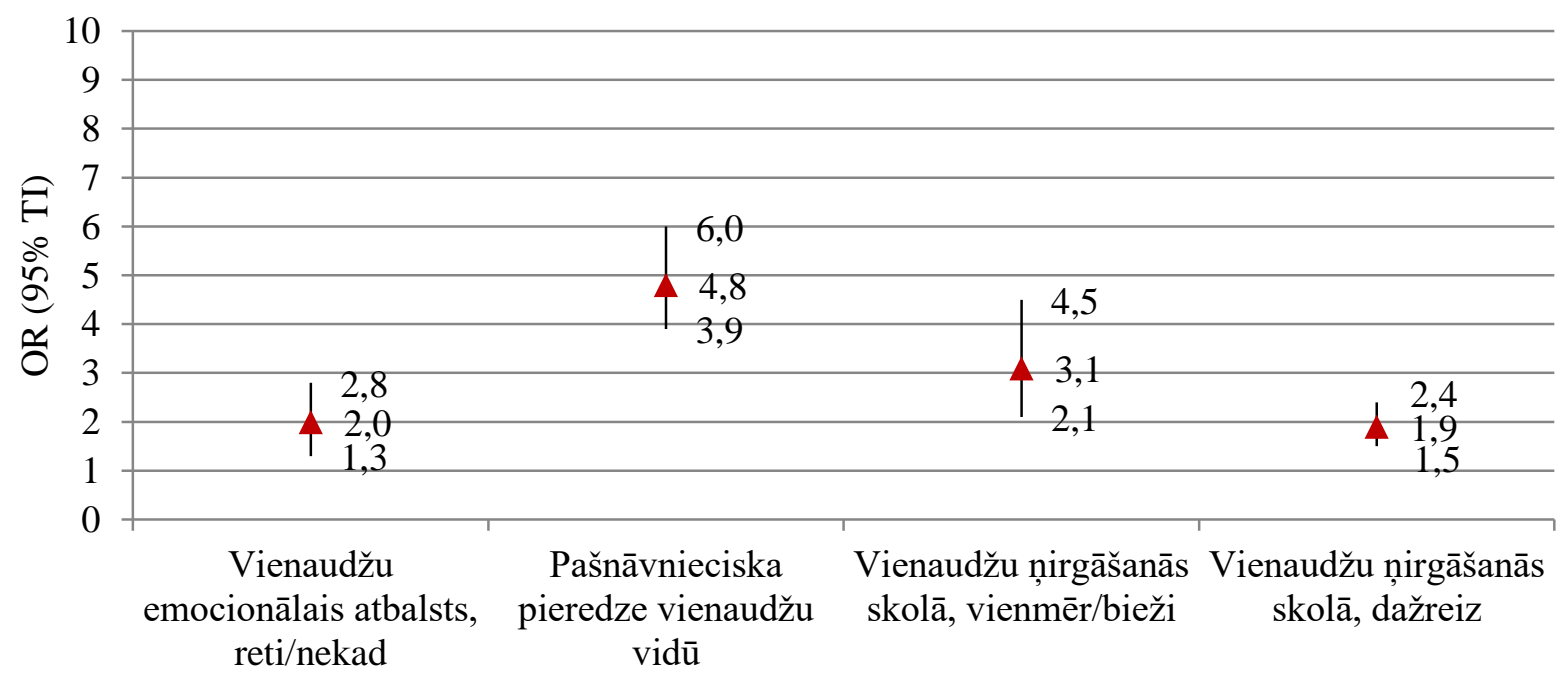

\subsection{2. attēls. Nesamērotās izredzes pašnāvības mēgeininājumam saistībā ar pētītajiem ar vienaudžu vidi saistītajiem faktoriem meitenēm}

Daudzfaktoru log̣istiskās regresijas modeḷos tika analizēta pētîto ar vienaudžu vidi saistīto faktoru neatkarīgā ietekme uz pusaudža pašnāvības mēginājumu dzimumu grupās. 
Kolinearitātes pārbaude starp neatkarīgajiem main̄̄gajiem dzimumu grupās liecina, ka kolinearitāte netraucē izdarīt secinājumus par regresijas modeḷos iekḷauto neatkarīgo mainīgo ietekmi uz atkarīgo main̄̄go - pašnāvības mēǵinājumu: abos dzimumos Tolerances testa vērtības main̄̄gajiem nav zemākas par 0,9 un VIF vērtības nepārsniedz 1,1. Neatkarīgo mainīgo savstarpējās korelācijas aprakstītas nodaḷā 3.4.1.

Sākotnēji tika veikta katra pētītā ar vienaudžu vidi saistītā faktora samērošana ar respondenta vecumu, pēc tam modelī 1 katrs no pētītajiem faktoriem tika samērots ar respondenta vecumu un gimenes materiālo stāvokli, savukārt modelī 2 katrs no pētîtajiem faktoriem tika samērots ar respondenta vecumu, ǵimenes materiālo stāvokli un pētītajiem ar vienaudžu vidi saistītajiem faktoriem.

Pēc sākotnēji veiktās katra pētītā faktora samērošanas ar respondenta vecumu iegūtie rezultāti liecina, ka izredžu attiecību izmaiņas pašnāvības mēǵinājumam, salīdzinot ar nesamērotajiem rādītājiem, ir: 0,0\%-2,5\% zēniem un 0,0\%-3,2\% meitenēm.

Pēc modelī 1 veiktās katra pētītā faktora samērošanas ar respondenta vecumu un ǵimenes materiālo stāvokli iegūtie rezultāti liecina, ka izredžu attiecību izmaiņas pašnāvības mēg̣inājumam, salīdzinot ar nesamērotajiem rādītājiem, ir: 0,0\%-5,0\% zēniem un 0,0\%-5,0\% meitenēm un visas sakarības, kuras bija statistiski nozīmīgas vienfaktora analīzē, saglabājas statistiski nozīmīgas arī pēc samērošanas modelī 1 .

Pēc modelī 2 veiktās faktoru samērošanas ar respondenta vecumu, ǵimenes materiālo stāvokli un pētītajiem ar vienaudžu vidi saistîtajiem faktoriem katra atsevišḳāa vienaudžu vidi raksturojošā statistiski nozīmīgā faktora neatkarīgais efekts uz pašnāvības mēginājumu samazinās abos dzimumos (sk. 3.24. tab.).

Reti/nekad un dažreiz saņemts vienaudžu emocionālais atbalsts zēniem pašnāvības mēǵinājuma izredzes statistiski nozīmīgi nepalielina ne vienfaktora analīzē, ne pēc samērošanas ar respondenta vecumu un ǵimenes materiālo stāvokli modelī 1 , ne pēc samērošanas ar respondenta vecumu, ğimenes materiālo stāvokli un citiem pētītajiem ar vienaudžu vidi saistītajiem faktoriem modelī 2. Savukārt meiteņu vidū reti/nekad saṇemts vienaudžu emocionālais atbalsts pēc samērošanas ar respondenta vecumu un gimenes materiālo stāvokli pašnāvības mēginājuma izredzes palielina gandrīz divas reizes $(\mathrm{OR}=1,9)$, salīdzinot ar meitenēm, kuras vienaudžu emocionālo atbalstu saņem vienmēr/bieži, taču dažreiz saņemts vienaudžu emocionālais atbalsts pašnāvības mēg̊inājuma izredzes statistiski noz̄imīgi nepalielina. Pēc samērošanas ar respondenta vecumu, gimenes materiālo stāvokli un citiem pētītajiem faktoriem meitenēm 1,6 reizes lielākas izredzes pašnāvības mēgeinājumam vērojamas reti/nekad saņemta vienaudžu emocionālā atbalsta gadījumā, bet attiecībā uz kategoriju “dažreiz” saistība nav statistiski nozīmīga arī šajā dzimumu grupā (sk. 3.24. tab.). 
Pašnāvnieciska pieredze vienaudžu vidū pēc samērošanas ar respondenta vecumu un ǵimenes materiālo stāvokli zēniem pašnāvības mēǵinājuma izredzes palielina gandrīz septiņas reizes $(\mathrm{OR}=6,8)$, bet pēc samērošanas ar respondenta vecumu, ǵimenes materiālo stāvokli un citiem pētītajiem vienaudžu vidi raksturojošajiem faktoriem - 6,5 reizes, salīdzinot ar zēniem bez pašnāvnieciskas pieredzes vienaudžu vidū. Meiteņu vidū pēc samērošanas ar respondenta vecumu un gimenes materiālo stāvokli pašnāvnieciska pieredze vienaudžu vidū pašnāvības mēǵinājuma izredzes palielina gandrīz piecas reizes $(\mathrm{OR}=4,8)$, bet pēc samērošanas ar respondenta vecumu, ǵimenes materiālo stāvokli un citiem pētītajiem vienaudžu vidi raksturojošajiem faktoriem $-4,5$ reizes, salīdzinot ar meitenēm bez pašnāvnieciskas pieredzes vienaudžu vidū (sk. 3.24. tab.).

Vienmēr/bieži piedzīvota vienaudžu ņirgāšanās skolā pēc samērošanas ar respondenta vecumu un gimenes materiālo stāvokli zēniem pašnāvības mēginājuma izredzes palielina gandrīz četras reizes $(\mathrm{OR}=3,8)$, savukārt zēniem, kuri emocionālo vardarbību piedzīvojuši dažreiz - gandrīz divas reizes $(\mathrm{OR}=1,8)$, bet pēc samērošanas ar respondenta vecumu, gimenes materiālo stāvokli un citiem pētītajiem vienaudžu vidi raksturojošajiem faktoriem izredzes pašnāvības mēǵinājumam ir attiecīgi 3,1 un 1,7 reizes augstākas, salīdzinot ar zēniem, kuri vienaudžu ņirgāšanos skolā nav piedzīvojuši. Savukārt meiteņu vidū vienmēr/bieži piedzīvota vienaudžu ņirgāšanās skolā pēc samērošanas ar respondenta vecumu un gimenes materiālo stāvokli pašnāvības mēg̣inājuma izredzes palielina trīs reizes, dažreiz piedzīvota vienaudžu ņirgāšanās - gandrīz divas reizes $(\mathrm{OR}=1,9)$, bet pēc samērošanas ar respondenta vecumu, gimenes materiālo stāvokli un citiem pētītajiem faktoriem izredzes pašnāvības mēginājumam ir attiecīgi 2,3 un 1,7 reizes augstākas, salīdzinot ar meitenēm, kuras vienaudžu ṇirgāšanos skolā nav piedzīvojušas (sk. 3.24. tab.). 


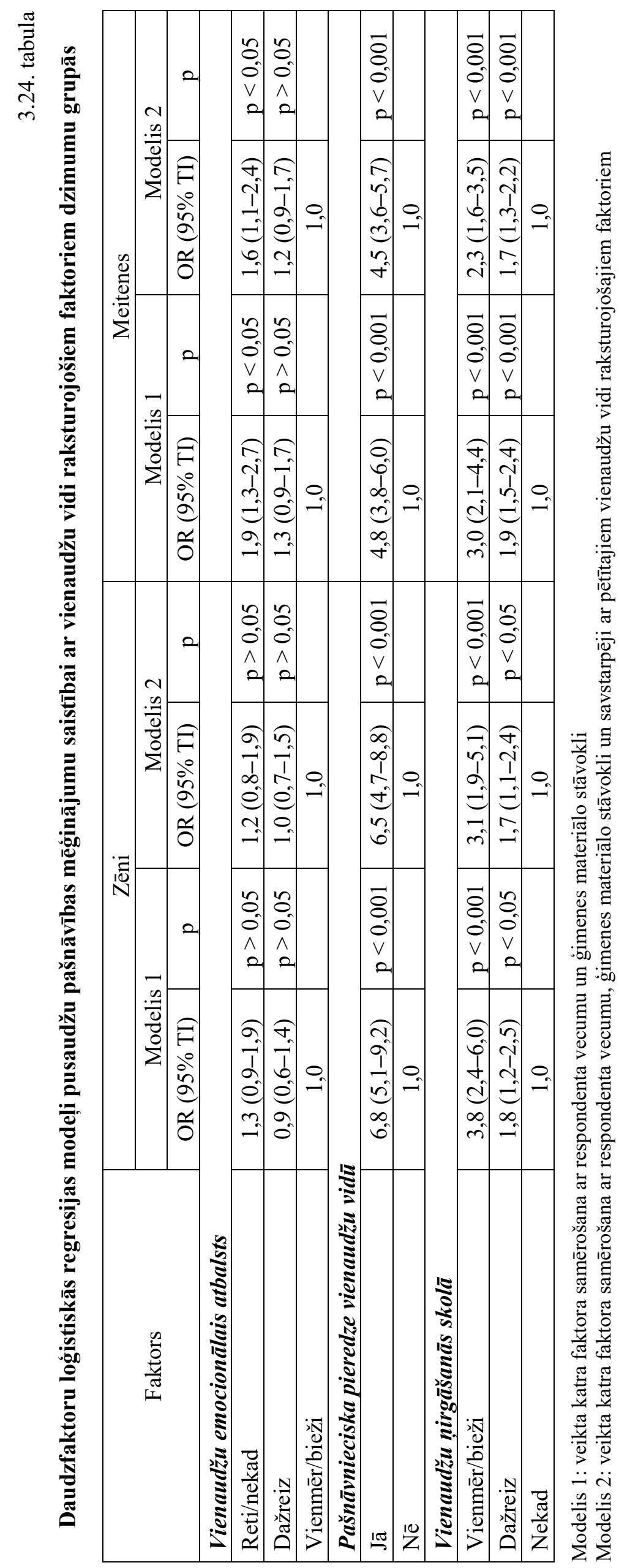




\subsection{Pašnāvnieciskā uzvedība un individuālie faktori}

Nodaḷā analizēta sekojošu individuālo faktoru saistība ar pusaudža pašnāvniecisko uzvedību: depresijas simptomu līmenis, pašcieņas līmenis, veselības pašvērtējums, riskanta alkohola lietošana, ikdienas smēḳēšana un narkotiku lietošana.

Kopējais respondentu sadalījums pēc depresijas simptomu līmeņa ir sekojošs: 22,4\% $(\mathrm{n}=1613 ; 95 \% \mathrm{TI}=21,4-23,4)$ respondentu depresijas simptomu līmenis iedalāms kategorijā "augsts", 33,5\% (n=2 415; 95\% TI = 32,4-34,6) - "vidēji augsts", bet 44,1\% (n=3 179; 95\% TI $=43,0-45,3)-$ "zems".

Attiecībā uz kopējo respondentu sadalījumu pēc pašcieņas līmeṇa situācija ir sekojoša: 27,9\% ( $\mathrm{n}=1$ 960; 95\% TI = 26,8-28,9) respondentu pašcieņas līmenis iedalāms kategorijā “zems", 27,5\% (n=1 937; 95\%TI = 26,5-28,6) - "vidēji zems", bet 44,6\% (n=3 140; 95\% TI $=43,5-45,8)-$ "augsts".

Uz jautājumu par apmierinātību ar savu veselības stāvokli respondentu atbilžu sadalījums ir sekojošs: 6,9\% $(\mathrm{n}=501 ; 95 \% \mathrm{TI}=6,3-7,5)$ respondentu ar savu veselïbas stāvokli ir neapmierināti, $11,0 \%(\mathrm{n}=797 ; 95 \% \mathrm{TI}=10,3-11,7)$ respondentu ar savu veselības stāvokli ir vidēji apmierināti, savukārt 82,1\% $(\mathrm{n}=5$ 958; 95\% TI = 81,2-83,0) - apmierināti.

Attiecībā uz riskantu alkohola lietošanu situācija ir sekojoša: 32,2\% (n = 2 324; 95\% TI $=31,1-33,3)$ respondentu piedzērušies trīs un vairāk reizes, 30,8\% $(\mathrm{n}=2$ 220; 95\% TI = 29,7$31,8)$ - vienu līdz divas reizes, bet 37,0\% $(\mathrm{n}=2670 ; 95 \% \mathrm{TI}=35,9-38,1)$ respondentu atzīmējuši, ka dz̄ives laikā nav piedzērušies.

Savukārt attiecībā uz ikdienas smēḳēšanu situācija ir sekojoša: 25,7\% (n=1 875; 95\% TI = 24,7-26,7) respondentu klasificējami kā ikdienas smēḳētāji, savukārt 74,3\% (n = 5411; 95\% TI = 73,2-75,3) kā ikdienas smēḳētāji nav klasificējami.

Attiecībā uz narkotiku lietošanu situācija ir sekojoša: 27,9\% (n = 2 026; 95\% TI = 26,9-28,9) respondentu ir lietojuši vienu vai vairākas promocijas darba ietvaros analizētās narkotikas, savukārt 72,1\% $(\mathrm{n}=5241 ; 95 \% \mathrm{TI}=71,1-73,1)$ respondenti atzīmējuši, ka šīs narkotikas dzīves laikā nav lietojuši.

Individuālo faktoru izplatība dzimumu grupās redzama 3.25. tabulā. 
Individuālo faktoru izplatība dzimumu grupās

\begin{tabular}{|c|c|c|c|}
\hline \multicolumn{2}{|c|}{ Individuālie faktori } & Zēni & Meitenes \\
\hline \multicolumn{4}{|c|}{ Depresijas simptomu līmenis } \\
\hline \multirow{2}{*}{ Augsts } & $\mathrm{n}$ & 477 & 1136 \\
\hline & $\%(95 \% \mathrm{TI})$ & $14,0(12,9-15,2)$ & $29,9(28,5-31,4)$ \\
\hline \multirow{2}{*}{ Vidēji augsts } & $\mathrm{n}$ & 1078 & 1337 \\
\hline & $\%(95 \% \mathrm{TI})$ & $31,6(30,1-33,2)$ & $35,2(33,7-36,7)$ \\
\hline \multirow{2}{*}{ Zems } & $\mathrm{n}$ & 1855 & 1324 \\
\hline & $\%(95 \% \mathrm{TI})$ & $54,4(52,7-56,1)$ & $34,9(33,4-36,4)$ \\
\hline \multicolumn{4}{|c|}{ Pašcieṇas līmenis } \\
\hline \multirow{2}{*}{ Zems } & $\mathrm{n}$ & 586 & 1104 \\
\hline & $\%(95 \% \mathrm{TI})$ & $25,9(24,4-27,4)$ & $29,6(28,2-31,1)$ \\
\hline \multirow{2}{*}{ Vidēji zems } & $\mathrm{n}$ & 885 & 1052 \\
\hline & $\%(95 \% \mathrm{TI})$ & $26,7(25,3-28,3)$ & $28,2(26,8-29,7)$ \\
\hline \multirow{2}{*}{ Augsts } & $\mathrm{n}$ & 1568 & 1572 \\
\hline & $\%(95 \% \mathrm{TI})$ & $47,4(45,7-49,1)$ & $42,2(40,6-43,8)$ \\
\hline \multicolumn{4}{|c|}{ Apmierinātība ar veselības stāvokli } \\
\hline \multirow{2}{*}{ Neapmierināts } & $\mathrm{n}$ & 168 & 333 \\
\hline & $\%(95 \% \mathrm{TI})$ & $4,9(4,2-5,7)$ & $8,7(7,9-9,7)$ \\
\hline \multirow{2}{*}{$\begin{array}{l}\text { Vidēji } \\
\text { apmierināts }\end{array}$} & $\mathrm{n}$ & 282 & 515 \\
\hline & $\%(95 \% \mathrm{TI})$ & $8,2(7,3-9,2)$ & $13,5(12,4-14,6)$ \\
\hline \multirow{2}{*}{ Apmierināts } & $\mathrm{n}$ & 2989 & 2969 \\
\hline & $\%(95 \% \mathrm{TI})$ & $86,9(85,7-88,0)$ & $77,8(76,4-79,1)$ \\
\hline \multicolumn{4}{|c|}{ Piedzeršanās dzīves laikā } \\
\hline \multirow{2}{*}{$\begin{array}{l}3 \text { un vairāk } \\
\text { reizes }\end{array}$} & $\mathrm{n}$ & 1231 & 1093 \\
\hline & $\%(95 \% \mathrm{TI})$ & $35,9(34,3-37,5)$ & $28,9(27,4-30,3)$ \\
\hline \multirow{2}{*}{$1-2$ reizes } & $\mathrm{n}$ & 999 & 1221 \\
\hline & $\%(95 \% \mathrm{TI})$ & $29,1(27,6-30,7)$ & $32,3(30,8-33,8)$ \\
\hline \multirow{2}{*}{$\mathrm{Ne}$} & $\mathrm{n}$ & 1198 & 1472 \\
\hline & $\%(95 \% \mathrm{TI})$ & $34,9(33,4-36,6)$ & $38,9(37,3-40,4)$ \\
\hline \multicolumn{4}{|c|}{ Ikdienas smēḳēšana } \\
\hline \multirow{2}{*}{$\mathrm{Jā}$} & $\mathrm{n}$ & 1040 & 835 \\
\hline & $\%(95 \% \mathrm{TI})$ & $30,0(28,5-31,6)$ & $21,8(20,6-23,2)$ \\
\hline \multirow{2}{*}{$\mathrm{Ne \overline { }}$} & $\mathrm{n}$ & 2424 & 2987 \\
\hline & $\%(95 \% \mathrm{TI})$ & $70,0(68,4-71,5)$ & $78,2(76,8-79,4)$ \\
\hline \multicolumn{4}{|c|}{ Narkotiku lietošana dz̄̄ves laikā } \\
\hline \multirow{2}{*}{$\mathrm{Jā}$} & $\mathrm{n}$ & 1130 & 896 \\
\hline & $\%(95 \% \mathrm{TI})$ & $32,8(31,2-34,4)$ & $23,5(22,1-24,8)$ \\
\hline \multirow{2}{*}{$\mathrm{Ne \overline { }}$} & $\mathrm{n}$ & 2318 & 2923 \\
\hline & $\%(95 \% \mathrm{TI})$ & $67,2(65,6-68,8)$ & $76,5(75,2-77,9)$ \\
\hline
\end{tabular}




\subsubsection{Domas par pašnāvību un individuālie faktori}

Analizējot domu par pašnāvību saistību ar depresijas simptomu līmeni, abās dzimumu grupās vērojama statistiski nozīmīga domu par pašnāvību izredžu palielināšanās līdz ar depresijas simptomu līmeņa pieaugumu - respondentiem - zēniem ar vidēji augstu un augstu depresijas simptomu līmeni vērojamas attiecīgi 2,1 un 6,2 reizes augstākas izredzes domām par pašnāvību, salīdzinot ar respondentiem ar zemu depresijas simptomu līmeni (sk. 3.26. tab.).

Arī meitenēm ar vidēji augstu un augstu depresijas simptomu līmeni izredzes domām par pašnāvību ir attiecīgi 2,1 un 5,2 reizes augstākas, salīdzinot ar meitenēm, kurām depresijas simptomu līmenis ir zems (sk. 3.26. tab.).

3.26. tabula

Domu par pašnāvību saistība ar depresijas simptomu līmeni

\begin{tabular}{|l|c|c|c|c|}
\hline \multirow{2}{*}{ Domas par pašnāvību } & \multicolumn{3}{|c|}{ Depresijas simptomu līmenis } \\
\cline { 3 - 5 } & & Augsts & Vidēji augsts & Zems \\
\hline \multirow{3}{*}{ Zēni } & $\mathrm{n}$ & 138 & 135 & 116 \\
\cline { 2 - 5 } & $\%(95 \% \mathrm{TI})$ & $29,5(25,5-33,8)$ & $12,6(10,7-14,7)$ & $6,3(5,3-7,5)$ \\
\cline { 2 - 5 } & OR (95\% TI) & $6,2(4,7-8,2)^{* *}$ & $2,1(1,6-2,8)^{* *}$ & 1,0 \\
\hline \multirow{3}{*}{ Meitenes } & $\mathrm{n}$ & 381 & 231 & 118 \\
\cline { 2 - 5 } & $\%(95 \% \mathrm{TI})$ & $33,7(31,0-36,5)$ & $17,4(15,4-19,5)$ & $8,9(7,5-10,6)$ \\
\cline { 2 - 5 } & OR (95\% TI) & $5,2(4,1-6,5)^{* *}$ & $2,1(1,7-2,7)^{* *}$ & 1,0 \\
\hline
\end{tabular}

$* * \mathrm{p}<0,001$

Nesamēroto izredžu aprēḳins liecina, ka abās dzimumu grupās pastāv statistiski nozīmīga sakarība arī starp domām par pašnāvību un pašcieņas līmeni, turklāt abās dzimumu grupās vērojama statistiski nozīmīga domu par pašnāvību izredžu palielināšanās līdz ar pašcieņas līmeṇa samazināšanos. Respondentiem - zēniem ar vidēji zemu un zemu pašcieņas līmeni vērojamas attiecīgi 2,6 un gandrīz sešas reizes $(O R=5,9)$ lielākas izredzes domām par pašnāvību, salīdzinot ar zēniem ar augstu pašcieņas līmeni (sk. 3.27. tab.).

Savukārt meitenēm ar vidēji zemu un zemu pašcieņas līmeni izredzes domām par pašnāvību ir attiecīgi gandrīz divas $(\mathrm{OR}=1,8)$ un četras $(\mathrm{OR}=3,9)$ reizes augstākas, salīdzinot ar meitenēm, kurām pašcieņas līmenis ir augsts (sk. 3.27. tab.). 
Domu par pašnāvību saistība ar pašcieņas līmeni

\begin{tabular}{|l|c|c|c|c|}
\hline \multicolumn{2}{|c|}{ Domas par pašnāvību } & \multicolumn{3}{|c|}{ Pašcieņas līmenis } \\
\cline { 2 - 5 } & & Zems & Vidēji zems & Augsts \\
\hline \multirow{3}{*}{ Zēni } & $\mathrm{n}$ & 197 & 103 & 76 \\
\cline { 2 - 5 } & $\%(95 \% \mathrm{TI})$ & $23,3(20,6-26,2)$ & $11,7(9,9-14,0)$ & $4,9(3,9-6,1)$ \\
\cline { 2 - 5 } & OR (95\% TI) & $5,9(4,5-7,8)^{* *}$ & $2,6(1,9-3,5) * *$ & 1,0 \\
\hline \multirow{3}{*}{ Meitenes } & $\mathrm{n}$ & 355 & 192 & 173 \\
\cline { 2 - 5 } & $\%(95 \% \mathrm{TI})$ & $32,4(30,0-35,2)$ & $18,4(16,1-20,9)$ & $11,0(9,6-12,7)$ \\
\cline { 2 - 5 } & OR (95\% TI) & $3,9(3,2-4,7) * *$ & $1,8(1,4-2,3) * *$ & 1,0 \\
\hline
\end{tabular}

$* * \mathrm{p}<0,001$

Nesamēroto izredžu attiecību aprēḳins liecina, ka abās dzimumu grupās pastāv statistiski nozīmīga saistība arī starp respondenta domām par pašnāvību un veselības pašvērtējumu - respondentiem - zēniem, kuri ar savu veselības stāvokli ir vidēji apmierināti vai neapmierināti, ir attiecīgi 2,1 un gandrīz trīs reizes $(\mathrm{OR}=2,9)$ lielākas izredzes domām par pašnāvību, salīdzinot ar respondentiem - zēniem, kuri ar savu veselības stāvokli ir apmierināti (sk. 3.28. tab.).

Savukārt meiteņu vidū vērojams arī statistiski nozīmīgs domu par pašnāvību izredžu pieaugums atkarībā no apmierinātības līmeṇa ar savu veselību - meitenēm, kuras ar veselības stāvokli ir vidēji apmierinātas vai neapmierinātas, ir attiecīgi 2,1 un 3,7 reizes lielākas izredzes domām par pašnāvību, salīdzinot ar meitenēm, kuras ar savu veselības stāvokli ir apmierinātas (sk. 3.28. tab.).

3.28. tabula

Domu par pašnāvību saistība ar veselības pašvērtējumu

\begin{tabular}{|l|c|c|c|c|}
\hline \multirow{2}{*}{ Domas par pašnāvību } & \multicolumn{3}{c|}{ Apmierinātība ar veselības stāvokli } \\
\cline { 2 - 5 } & & Neapmierināts & Vidēji apmierināts & Apmierināts \\
\hline \multirow{3}{*}{ Zēni } & $\mathrm{n}$ & 41 & 54 & 303 \\
\cline { 2 - 5 } & $\%(95 \% \mathrm{TI})$ & $25,2(19,1-32,3)$ & $19,3(15,1-24,3)$ & $10,2(9,2-11,4)$ \\
\cline { 2 - 5 } & OR (95\% TI) & $2,9(2,0-4,3)^{* *}$ & $2,1(1,5-2,9)^{* *}$ & 1,0 \\
\hline \multirow{3}{*}{ Meitenes } & $\mathrm{n}$ & 134 & 145 & 458 \\
\cline { 2 - 5 } & $\%(95 \% \mathrm{TI})$ & $40,6(35,4-46,0)$ & $28,3(24,5-32,3)$ & $15,5(14,2-16,8)$ \\
\cline { 2 - 5 } & OR (95\% TI) & $3,7(2,9-4,7)^{* *}$ & $2,1(1,7-2,7)^{* *}$ & 1,0 \\
\hline
\end{tabular}

$* * \mathrm{p}<0,001$

Analizējot pusaudžu domas par pašnāvību saistībā ar riskantu alkohola lietošanu, nesamēroto izredžu aprēḳins liecina, ka abu dzimumu respondentiem, kuri dzīves laikā piedzērušies, ir statistiski nozīmīgi lielākas izredzes domām par pašnāvību, salīdzinot ar 
respondentiem, kuri nav piedzērušies. Zēniem, kuri piedzērušies $1-2$ vai 3 un vairāk reizes, ir attiecīgi 1,4 un gandrīz divas reizes $(\mathrm{OR}=1,9)$ lielākas izredzes domām par pašnāvību, salīdzinot ar respondentiem - zēniem, kuri atzīmējuši, ka dzīves laikā nav piedzērušies (sk. 3.29. tab.).

Savukārt meitenēm vērojams arī statistiski nozīmīgs domu par pašnāvību izredžu pieaugums atkarībā no piedzeršanās reižu skaita, proti, meitenēm, kuras dzīves laikā piedzērušās 1-2 reizes, vērojamas 1,7 reizes lielākas izredzes domām par pašnāvību, bet meitenēm, kuras atzīmējušas, ka dzīves laikā piedzērušās 3 un vairāk reizes - gandrīz trīs reizes $(\mathrm{OR}=2,9)$ lielākas izredzes domām par pašnāvību, salīdzinot ar meitenēm, kuras atzīmējušas, ka dzīves laikā nav piedzērušās (sk. 3.29. tab.).

3.29. tabula

\section{Domu par pašnāvību saistība ar riskantu alkohola lietošanu}

\begin{tabular}{|l|c|c|c|c|}
\hline \multirow{2}{*}{ Domas par pašnāvību } & \multicolumn{3}{c|}{ Piedzeršanās dzīves laikā } \\
\cline { 2 - 5 } & & 3 un vairāk reizes & $1-2$ reizes & Nē \\
\hline \multirow{3}{*}{ Zēni } & $\mathrm{n}$ & 183 & 112 & 100 \\
\cline { 2 - 5 } & $\%(95 \% \mathrm{TI})$ & $15,0(13,1-17,1)$ & $11,3(9,5-13,4)$ & $8,4(7,0-10,2)$ \\
\cline { 2 - 5 } & OR (95\% TI) & $1,9(1,5-2,5)^{* *}$ & $1,4(1,0-1,8)^{*}$ & 1,0 \\
\hline \multirow{3}{*}{ Meitenes } & $\mathrm{n}$ & 312 & 233 & 179 \\
\cline { 2 - 5 } & $\%(95 \% \mathrm{TI})$ & $28,7(26,1-31,4)$ & $19,1(17,0-21,4)$ & $12,2(10,6-14,0)$ \\
\cline { 2 - 5 } & OR $(95 \% \mathrm{TI})$ & $2,9(2,3-3,5)^{* *}$ & $1,7(1,4-2,1)^{* *}$ & 1,0 \\
\hline
\end{tabular}

$* \mathrm{p}<0,05 ; * \mathrm{p}<0,001$

Abās dzimumu grupās vērojama statistiski nozīmīga saistība starp domām par pašnāvību un ikdienas smēḳēěanu - respondentiem - zēniem, kuri ikdienā smēḳēe, ir divas reizes lielākas izredzes domām par pašnāvību, salīdzinot ar zēniem, kuri ikdienā nesmēķē (sk. 3.30. tab.).

Savukārt meitenēm, kuras ikdienā smēķē, vērojamas 2,2 reizes lielākas izredzes domām par pašnāvību, salīdzinot ar meitenēm, kuras ikdienā nesmēḳēe (sk. 3.30. tab.).

3.30. tabula

Domu par pašnāvību saistība ar ikdienas smēḳēšanu

\begin{tabular}{|c|c|c|c|}
\hline \multirow{2}{*}{\multicolumn{2}{|c|}{ Domas par pašnāvību }} & \multicolumn{2}{|c|}{ Ikdienas smēķēšana } \\
\hline & & \multirow[t]{2}{*}{$\mathrm{Jā}$} & $\mathrm{Nē}$ \\
\hline \multirow{3}{*}{ Zēni } & $\mathrm{n}$ & & 225 \\
\hline & $\%(95 \% \mathrm{TI})$ & $17,1(15,0-19,5)$ & $9,4(8,3-10,6)$ \\
\hline & OR $(95 \% \mathrm{TI})$ & $2,0(1,6-2,5)^{* *}$ & 1,0 \\
\hline \multirow{3}{*}{ Meitenes } & $\mathrm{n}$ & 249 & 487 \\
\hline & $\%(95 \% \mathrm{TI})$ & $30,0(27,0-33,2)$ & $16,4(15,1-17,7)$ \\
\hline & OR $(95 \% \mathrm{TI})$ & $2,2(1,8-2,6)^{* *}$ & 1,0 \\
\hline
\end{tabular}

** $\mathrm{p}<0,001$ 
Abās dzimumu grupās vērojama arī statistiski nozīmīga saistība starp domām par pašnāvību un narkotiku lietošanu dzīves laikā. Respondentiem - zēniem, kuri dz̄̄ves laikā lietojuši marihuānu/hašišu, amfetamīnu, LSD/citus halucinogēnus, kreku, kokaīnu, heroīnu, ekstazī un/vai spice, vērojamas 2,2 reizes lielākas izredzes domām par pašnāvību, salīdzinot ar zēniem, kuri dzīves laikā iepriekš minētās narkotikas nav lietojuši (sk. 3.31. tab.).

Savukārt meitenēm, kuras dzīves laikā lietojušas iepriekš minētās narkotikas, vērojamas 2,1 reizi lielākas izredzes domām par pašnāvību, salīdzinot ar meitenēm, kuras atzīmējušas, ka iepriekš minētās narkotikas nav lietojušas (sk. 3.31. tab.).

3.31. tabula

Domu par pašnāvību saistība ar narkotiku lietošanu

\begin{tabular}{|l|c|c|c|}
\hline \multicolumn{2}{|c|}{ Domas par pašnāvību } & \multicolumn{2}{c|}{ Narkotiku lietošana dzīves laikā } \\
\cline { 2 - 4 } & & $\mathrm{Ja}$ & $\mathrm{Ne}$ \\
\hline \multirow{3}{*}{ Zēni } & $\mathrm{n}$ & 197 & 203 \\
\cline { 2 - 4 } & $\%(95 \% \mathrm{TI})$ & $17,6(15,5-19,9)$ & $8,8(7,7-10,1)$ \\
\cline { 2 - 4 } & OR $(95 \% \mathrm{TI})$ & $2,2(1,8-2,7)^{* *}$ & 1,0 \\
\hline \multirow{3}{*}{ Meitenes } & $\mathrm{n}$ & 263 & 473 \\
\cline { 2 - 4 } & $\%(95 \% \mathrm{TI})$ & $29,5(26,5-32,5)$ & $16,3(15,0-17,6)$ \\
\cline { 2 - 4 } & OR (95\% TI) & $2,1(1,8-2,6)^{* *}$ & 1,0 \\
\hline
\end{tabular}

$* * \mathrm{p}<0,001$

3.13. un 3.14. attēlos redzama apkopojoša informācija par nesamērotajām, statistiski nozīmīgajām izredzēm domām par pašnāvību saistībā ar pētîtajiem individuālajiem faktoriem zēniem un meitenēm. Abās dzimumu grupās sakarības ar visiem pētītajiem ar individuālajiem faktoriem ir statistiski nozīmīgas.

Zēnu vidū salīdzinoši augstākās izredzes domām par pašnāvību vērojamas respondentiem ar augstu depresijas simptomu lìmeni $(\mathrm{OR}=6,2)$ un zemu pašcieņas līmeni $(\mathrm{OR}=5,9)$ (sk. 3.13. att.).

Meiteņu vidū salīdzinoši skaitliski augstākās izredzes domām par pašnāvību vērojamas respondentiem ar augstu depresijas simptomu līmeni (OR = 5,2), zemu pašcieņas līmeni $(\mathrm{OR}=3,9)$ un neapmierinātību ar savu veselības stāvokli $(\mathrm{OR}=3,7)$ (sk. 3.14. att.). 


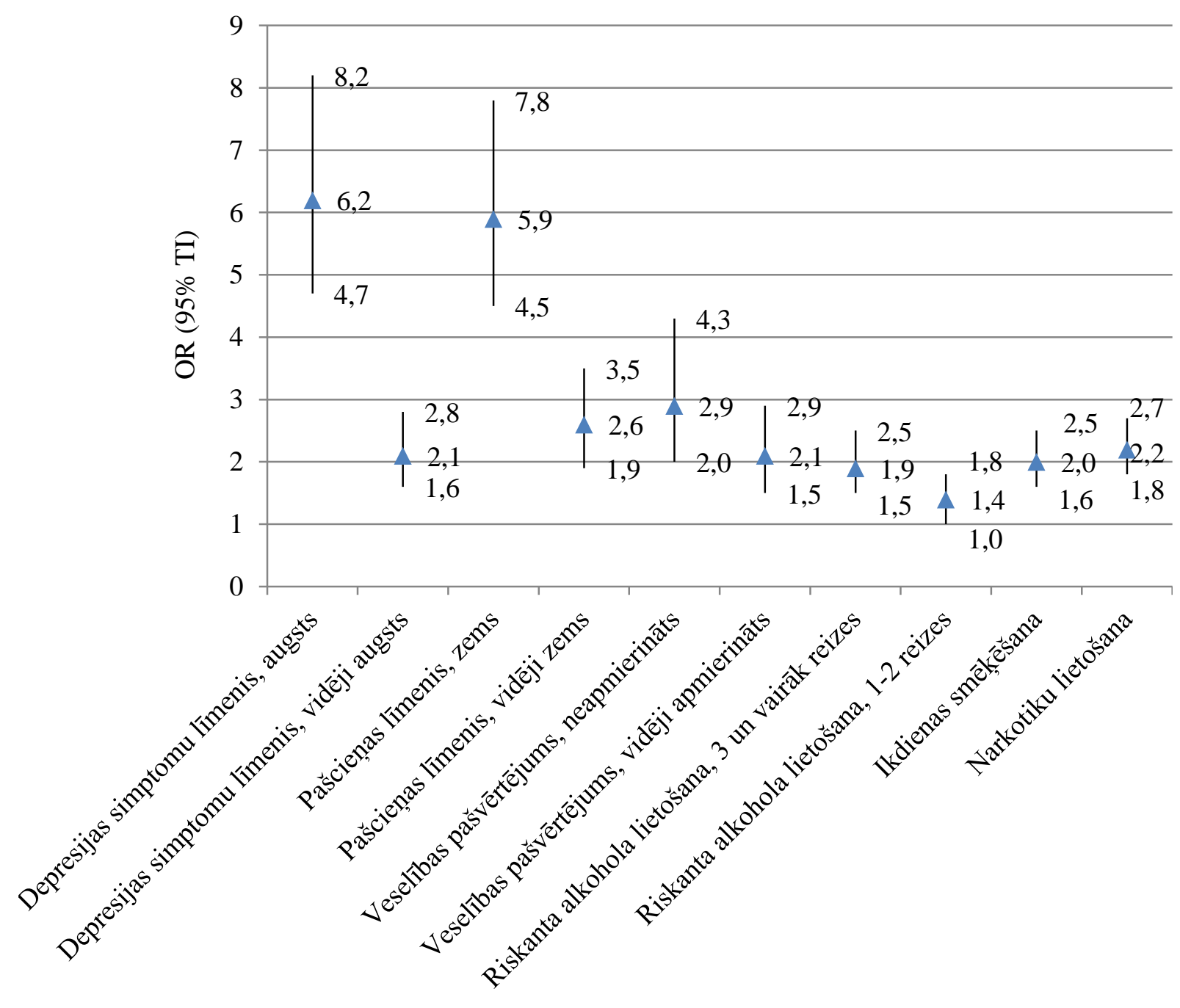

3.13. attēls. Nesamērotās izredzes domām par pašnāvību saistībā ar pētītajiem ar individuālajiem faktoriem zēniem 


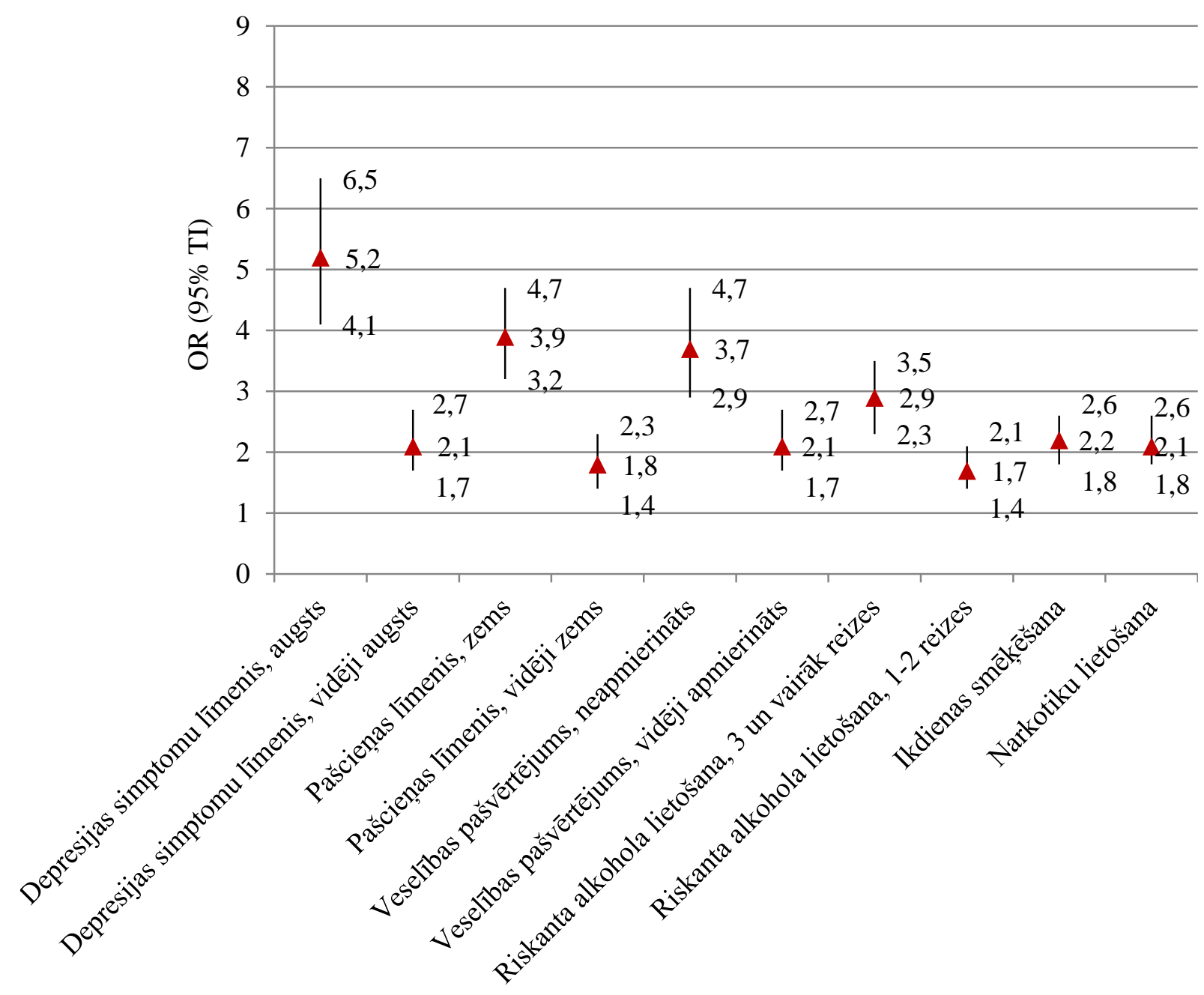

3.14. attēls. Nesamērotās izredzes domām par pašnāvību saistībā ar pētītajiem ar individuālajiem faktoriem meitenēm

Daudzfaktoru loǵistiskās regresijas modelıos tika analizēta pētîto individuālo faktoru neatkarīgā ietekme uz pusaudža domām par pašnāvību dzimumu grupās.

Kolinearitātes pārbaude starp neatkarīgajiem main̄̄gajiem dzimumu grupās liecina, ka kolinearitāte netraucē izdarīt secinājumus par regresijas modeḷos iekḷauto neatkarīgo mainīgo ietekmi uz atkarīgo main̄̄go - domām par pašnāvību: abās dzimumu grupās Spīrmena korelācijas koeficienti norāda uz nenozīmīgu korelāciju starp neatkarīgajiem main̄̄gajiem, izṇemot korelāciju starp depresijas simptomu līmeni un pašcieņas līmeni $(0,31)$, riskantu alkohola lietošanu un ikdienas smēḳēšanu $(0,39)$, riskantu alkohola lietošanu un narkotiku lietošanu $(0,39)$, ikdienas smēḳēšanu un narkotiku lietošanu $(0,34)$ - starp šiem mainīgajiem korelācijas ir vājas. Zēniem Tolerances testa vērtības mainīgajiem nav zemākas par 0,7 un VIF vērtības nepārsniedz 1,4. Savukārt meitenēm Tolerances testa vērtības mainīgajiem nav zemākas par 0,9 un VIF vērtības nepārsniedz 1,4. 
Sākotnēji dzimumu grupās tika veikta katra pētītā individuālā faktora samērošana ar respondenta vecumu, pēc tam modelī 1 katrs no pētītajiem faktoriem tika samērots ar respondenta vecumu un ǵimenes materiālo stāvokli, savukārt modelī 2 katrs no pētītajiem faktoriem tika samērots ar respondenta vecumu, gimenes materiālo stāvokli un citiem pētītajiem pusaudža individuālajiem faktoriem.

Pēc sākotnēji veiktās katra pētītā faktora samērošanas ar respondenta vecumu iegūtie rezultāti liecina, ka izredžu attiecību izmaiṇas, salīdzinot ar nesamērotajiem rādītājiem, ir: $0,0 \%-1,7 \%$ zēniem un $0,0 \%-1,9 \%$ meitenēm.

Pēc modelī 1 veiktās katra pētītā faktora samērošanas ar respondenta vecumu un gimenes materiālo stāvokli iegūtie rezultāti liecina, ka izredžu attiecību izmaiņas, salīdzinot ar nesamērotajiem rādītājiem, ir: $0,0 \%-9,5 \%$ zēniem un $0,0 \%-5,6 \%$ meitenēm un visas sakarības, kuras bija statistiski nozīmīgas vienfaktora analīzē, saglabājas statistiski nozīmīgas.

Pēc modelī 2 veiktās pētīto faktoru savstarpējās samērošanas ar respondenta vecumu, ǵimenes materiālo stāvokli un citiem pētītajiem individuālajiem faktoriem, katra atsevišḳā individuālā faktora neatkarīgais efekts uz domām par pašnāvību samazinās abos dzimumos (sk. 3.32. tab.).

Augsts depresijas simptomu līmenis pēc samērošanas ar respondenta vecumu un gimenes materiālo stāvokli zēniem domu par pašnāvību izredzes palielina gandrīz sešas reizes $(\mathrm{OR}=5,9)$, savukārt vidēji augsts depresijas simptomu līmenis - 2,1 reizi, bet pēc samērošanas ar respondenta vecumu, gimenes materiālo stāvokli un citiem pētītajiem individuālajiem faktoriem izredzes domām par pašnāvību ir attiecīgi 3,7 un 1,7 reizes augstākas, salīdzinot ar zēniem, kuru depresijas simptomu līmenis ir zems. Savukārt meiteņu vidū augsts depresijas simptomu līmenis pēc samērošanas ar respondenta vecumu un ǵimenes materiālo stāvokli domu par pašnāvību izredzes palielina 5,1 reizi, vidēji augsts depresijas simptomu līmenis - 2,1 reizi, bet pēc samērošanas ar respondenta vecumu, ǵimenes materiālo stāvokli un citiem individuālajiem faktoriem izredzes domām par pašnāvību ir attiecīgi trīs un 1,7 reizes augstākas, salīdzinot ar meitenēm, kuru depresijas simptomu līmenis ir zems (sk. 3.32. tab.).

Zems pašcieņas līmenis pēc samērošanas ar respondenta vecumu un gimenes materiālo stāvokli zēniem domu par pašnāvību izredzes palielina gandrīz sešas reizes $(\mathrm{OR}=5,9)$, savukārt vidēji zems pašcieņas līmenis - 2,5 reizes, bet pēc samērošanas ar respondenta vecumu, gimenes materiālo stāvokli un citiem pētītajiem individuālajiem faktoriem izredzes domām par pašnāvību ir attiecīgi gandrīz četras $(\mathrm{OR}=3,8)$ un divas reizes augstākas, salīdzinot ar zēniem, kuru pašcieņas līmenis ir augsts. Savukārt meiteņu vidū zems pašcieņas līmenis pēc samērošanas ar respondenta vecumu un ǵimenes materiālo stāvokli domu par 
pašnāvību izredzes palielina 3,7 reizes, vidēji zems pašcieņas līmenis - 1,7 reizes, bet pēc samērošanas ar respondenta vecumu, ǵimenes materiālo stāvokli un citiem individuālajiem faktoriem izredzes domām par pašnāvību ir attiecīgi 2,3 un 1,4 reizes augstākas, salīdzinot ar meitenēm, kuru pašcieņas līmenis ir augsts (sk. 3.32. tab.).

Neapmierinātība ar veselības stāvokli pēc samērošanas ar respondenta vecumu un ǵimenes materiālo stāvokli zēniem domu par pašnāvību izredzes palielina 2,7 reizes, savukārt vidēja apmierinātība - gandrīz divas reizes $(\mathrm{OR}=1,9)$, salīdzinot ar zēniem, kuri ar savu veselības stāvokli ir apmierināti, taču pēc samērošanas ar respondenta vecumu, ǵimenes materiālo stāvokli un citiem pētītajiem individuālajiem faktoriem domu par pašnāvību saistība ar neapmierinātību vai vidēju apmierinātību ar veselības stāvokli zēniem vairs nav statistiski nozīmīga. Savukārt meiteņu vidū neapmierinātība ar veselības stāvokli pēc samērošanas ar respondenta vecumu un ǵimenes materiālo stāvokli domu par pašnāvību izredzes palielina 3,5 reizes, vidēja apmierinātîba - 2,1 reizi, bet pēc samērošanas ar respondenta vecumu, ǵimenes materiālo stāvokli un citiem individuālajiem faktoriem izredzes domām par pašnāvību ir attiecīgi 2,1 un 1,5 reizes augstākas, salīdzinot ar meitenēm, kuras ar savu veselības stāvokli ir apmierinātas (sk. 3.32. tab.).

Riskanta alkohola lietošana 3 un vairāk reizes dzīves laikā pēc samērošanas ar respondenta vecumu un ǵimenes materiālo stāvokli zēniem domu par pašnāvību izredzes palielina gandrīz divas reizes $(\mathrm{OR}=1,8)$, savukārt riskanta alkohola lietošana $1-2$ reizes $-1,3$ reizes, salīdzinot ar zēniem, kuri dzīves laikā riskanti alkoholu nav lietojuši, taču pēc samērošanas ar respondenta vecumu, gimenes materiālo stāvokli un citiem pētītajiem individuālajiem faktoriem, domu par pašnāvību saistība ar riskantu alkohola lietošanu zēniem vairs nav statistiski nozīmīga. Savukārt meiteņu vidū riskanta alkohola lietošana 3 un vairāk reizes dzīves laikā pēc samērošanas ar respondenta vecumu un ǵimenes materiālo stāvokli domu par pašnāvību izredzes palielina gandrīz trīs reizes $(\mathrm{OR}=2,9)$, riskanta alkohola lietošana 1-2 reizes - 1,7 reizes, bet pēc samērošanas ar respondenta vecumu, gimenes materiālo stāvokli un citiem individuālajiem faktoriem izredzes domām par pašnāvību ir attiecīgi gandrīz divas $(\mathrm{OR}=1,8)$ un 1,3 reizes augstākas, salīdzinot ar meitenēm, kuras dz̄ives laikā riskanti alkoholu nav lietojušas (sk. 3.32. tab.).

Ikdienas smēḳēšana pēc samērošanas ar respondenta vecumu un giimenes materiālo stāvokli zēniem domu par pašnāvību izredzes palielina gandrīz divas reizes $(O R=1,9)$, bet pēc samērošanas ar respondenta vecumu, gimenes materiālo stāvokli un citiem pētītajiem individuālajiem faktoriem - 1,3 reizes, salīdzinot ar zēniem, kuri ikdienā nesmēḳē. Meiteņu vidū pēc samērošanas ar respondenta vecumu un ğimenes materiālo stāvokli ikdienas smēḳēšana domu par pašnāvību izredzes palielina 2,1 reizi, bet pēc samērošanas ar 
respondenta vecumu, ǵimenes materiālo stāvokli un citiem pētītajiem individuālajiem faktoriem - 1,4 reizes, salīdzinot ar meitenēm, kuras ikdienā nesmēḳēe (sk. 3.32. tab.).

Narkotiku lietošana dzīves laikā pēc samērošanas ar respondenta vecumu un ǵimenes materiālo stāvokli zēniem domu par pašnāvību izredzes palielina 2,2 reizes, bet pēc samērošanas ar respondenta vecumu, gimenes materiālo stāvokli un citiem pētītajiem individuālajiem faktoriem - 1,4 reizes, salīdzinot ar zēniem, kuri marihuānu/hašišu, amfetamīnu, LSD/citus halucinogēnus, kreku, kokaīnu, herōinu, ekstazī un/vai spice nav lietojuši. Meitenu vidū pēc samērošanas ar respondenta vecumu un gimenes materiālo stāvokli narkotiku lietošana dzīves laikā domu par pašnāvību izredzes palielina 2,1 reizi, bet pēc samērošanas ar respondenta vecumu, gimenes materiālo stāvokli un citiem pētītajiem individuālajiem faktoriem - 1,4 reizes, salīdzinot ar meitenēm, kuras marihuānu/hašišu, amfetamīnu, LSD/citus halucinogēnus, kreku, kokaīnu, heroīnu, ekstazī un/vai spice dzīves laikā nav lietojušas (sk. 3.32. tab.). 


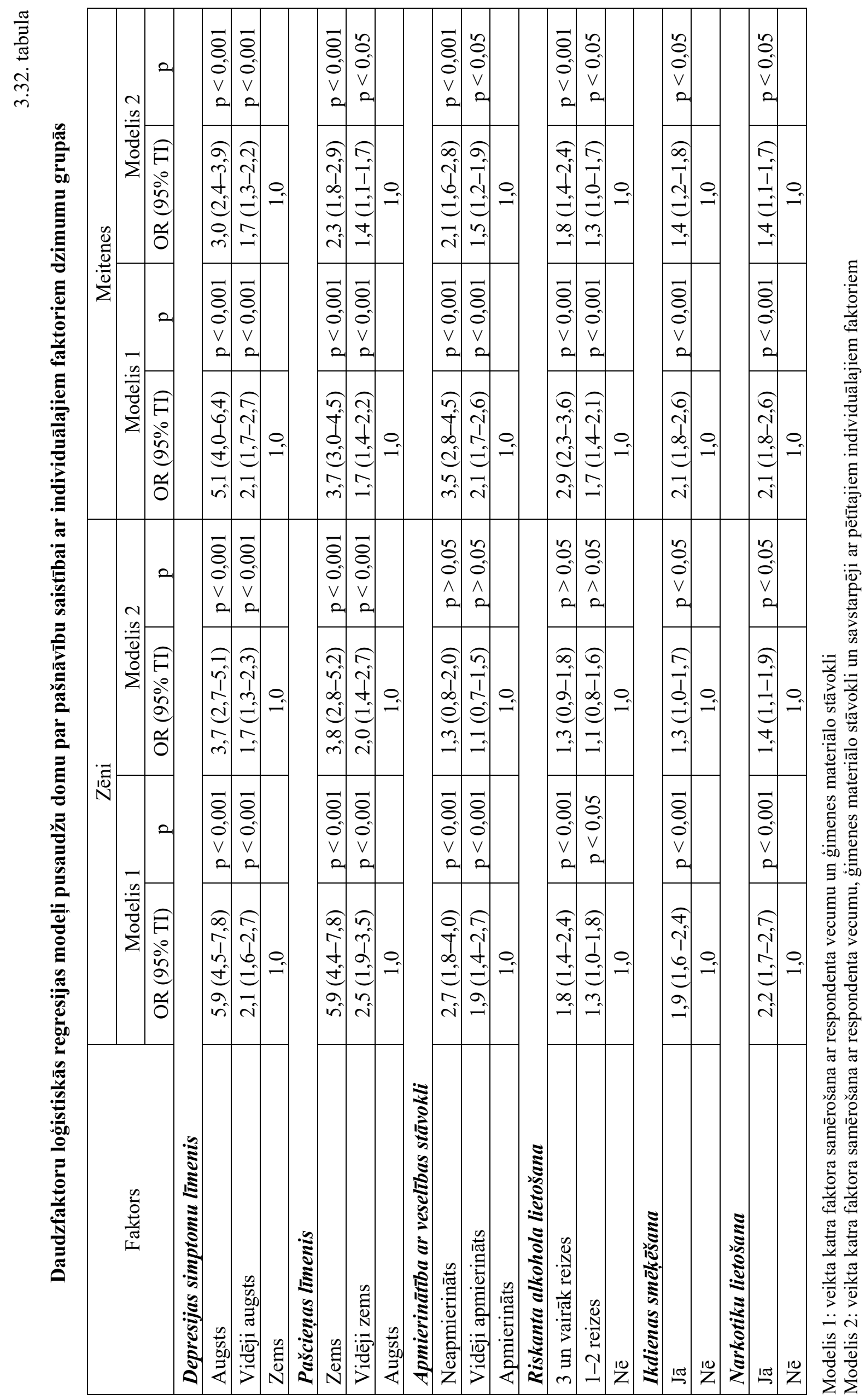




\subsubsection{Pašnāvības mēgeinājumi un individuālie faktori}

Analizējot pašnāvības mēǵinājumu saistību ar depresijas simptomu līmeni, abās dzimumu grupās vērojama statistiski nozīmīga pašnāvības mēǵinājuma izredžu palielināšanās līdz ar depresijas simptomu līmeņa pieaugumu. Zēniem ar vidēji augstu un augstu depresijas simptomu līmeni vērojamas attiecīgi 2,3 un 6,4 reizes augstākas izredzes pašnāvības mēǵinājumam, salīdzinot ar respondentiem ar zemu depresijas simptomu līmeni (sk. 3.33. tab.).

Arī meitenēm ar vidēji augstu un augstu depresijas simptomu līmeni izredzes pašnāvības mēǵinājumam ir attiecīgi 2,1 un gandrīz piecas reizes $(\mathrm{OR}=4,8)$ augstākas, salīdzinot ar meitenēm, kurām depresijas simptomu līmenis ir zems (sk. 3.33. tab.).

3.33. tabula

Pašnāvības mēḡinājumu saistība ar depresijas simptomu līmeni

\begin{tabular}{|l|c|c|c|c|}
\hline \multirow{2}{*}{ Pašnāvības mēǵinājums } & \multicolumn{3}{|c|}{ Depresijas simptomu līmenis } \\
\cline { 2 - 5 } & & Augsts & Vidēji augsts & Zems \\
\hline \multirow{3}{*}{ Zēni } & $\mathrm{n}$ & 76 & 69 & 53 \\
\cline { 2 - 5 } & $\%(95 \% \mathrm{TI})$ & $16,0(13,0-19,6)$ & $6,4(5,1-8,0)$ & $2,9(2,2-3,7)$ \\
\cline { 2 - 5 } & OR (95\% TI) & $6,4(4,5-9,3) * *$ & $2,3(1,6-3,3) * *$ & 1,0 \\
\hline \multirow{3}{*}{ Meitenes } & $\mathrm{n}$ & 207 & 120 & 59 \\
\cline { 2 - 5 } & $\%(95 \% \mathrm{TI})$ & $18,2(16,1-20,6)$ & $9,0(7,6-10,6)$ & $4,5(3,5-5,7)$ \\
\cline { 2 - 5 } & OR (95\% TI) & $4,8(3,5-6,4)^{* *}$ & $2,1(1,5-2,9)^{* *}$ & 1,0 \\
\hline
\end{tabular}

$* * \mathrm{p}<0,001$

Abās dzimumu grupās pastāv statistiski nozīmīga sakarība arī starp pašnāvības mēginājumu un pašcieņas līmeni, turklāt abās dzimumu grupās vērojama statistiski nozīmīga pašnāvības mēǵinājuma izredžu palielināšanās līdz ar pašcieņas līmeņa samazināšanos. Respondentiem - zēniem ar vidēji zemu un zemu pašcieņas līmeni vērojamas attiecīgi gandrīz trīs $(\mathrm{OR}=2,8)$ un gandrīz astoṇas $(\mathrm{OR}=7,9)$ reizes lielākas izredzes pašnāvība mēǵinājumam, salīdzinot ar zēniem ar augstu pašcieṇas līmeni (sk. 3.34. tab.).

Savukārt meitenēm ar vidēji zemu un zemu pašcieņas līmeni izredzes pašnāvības mēǵinājumam ir attiecīgi gandrīz 2,1 un gandrīz četras reizes $(\mathrm{OR}=3,8)$ augstākas, salīdzinot ar meitenēm, kurām pašcieņas līmenis ir augsts (sk. 3.34. tab.). 
Pašnāvības mēgéninājumu saistība ar pašcieṇas līmeni

\begin{tabular}{|l|c|c|c|c|}
\hline \multirow{2}{*}{ Pašnāvības mēǵinājums } & \multicolumn{3}{|c|}{ Pašcieņas līmenis } \\
\cline { 2 - 5 } & & Zems & Vidēji zems & Augsts \\
\hline \multirow{3}{*}{ Zēni } & $\mathrm{n}$ & 111 & 45 & 29 \\
\cline { 2 - 5 } & $\%(95 \% \mathrm{TI})$ & $13,0(10,9-15,4)$ & $5,1(3,8-6,7)$ & $1,9(1,3-2,6)$ \\
\cline { 2 - 5 } & OR (95\% TI) & $7,9(5,2-12,0)^{* *}$ & $2,8(1,8-4,6)^{* *}$ & 1,0 \\
\hline \multirow{3}{*}{ Meitenes } & $\mathrm{n}$ & 191 & 108 & 82 \\
\cline { 2 - 5 } & $\%(95 \% \mathrm{TI})$ & $17,3(15,2-19,7)$ & $10,3(8,6-12,3)$ & $5,2(4,2-6,4)$ \\
\cline { 2 - 5 } & OR (95\% TI) & $3,8(2,9-5,0)^{* *}$ & $2,1(1,5-2,8)^{* *}$ & 1,0 \\
\hline
\end{tabular}

** $\mathrm{p}<0,001$

Nesamēroto izredžu attiecību aprēķins liecina, ka abās dzimumu grupās pastāv statistiski nozīmīga saistība arī starp pašnāvības mēginājumiem un respondenta veselības pašvērtējumu. Respondentiem - zēniem, kuri ar savu veselības stāvokli ir vidēji apmierināti vai neapmierināti, ir attiecīgi 2,5 un 4,5 reizes lielākas izredzes pašnāvības mēginājumam, salīdzinot ar zēniem, kuri ar savu veselības stāvokli ir apmierināti (sk. 3.35. tab.).

Savukārt meiteṇu vidū vērojams arī statistiski nozīmīgs pašnāvības mēgeinājuma izredžu pieaugums atkarībā no apmierinātības līmeņa ar savu veselību - meitenēm, kuras ar veselības stāvokli ir vidēji apmierinātas vai neapmierinātas, ir attiecīgi gandrīz divas (OR = 1,9) un 3,6 reizes lielākas izredzes pašnāvības mēginājumam, salīdzinot ar meitenēm, kuras ar savu veselības stāvokli ir apmierinātas (sk. 3.35. tab.).

3.35. tabula

Pašnāvības mēgeinājumu saistība ar veselības pašvērtējumu

\begin{tabular}{|l|c|c|c|c|}
\hline \multirow{2}{*}{ Pašnāvības mēǵinājums } & \multicolumn{3}{|c|}{ Apmierinātība ar veselības stāvokli } \\
\cline { 2 - 5 } & & Neapmierināts & Vidēji apmierināts & Apmierināts \\
\hline \multirow{3}{*}{ Zēni } & $\mathrm{n}$ & 30 & 31 & 140 \\
\cline { 2 - 5 } & $\%(95 \% \mathrm{TI})$ & $18,1(13,0-24,6)$ & $11,1(7,9-15,3)$ & $4,7(4,0-5,5)$ \\
\cline { 2 - 5 } & OR (95\% TI) & $4,5(2,9-6,9)^{* *}$ & $2,5(1,7-3,8)^{* *}$ & 1,0 \\
\hline \multirow{3}{*}{ Meitenes } & $\mathrm{n}$ & 79 & 72 & 237 \\
\cline { 2 - 5 } & $\%(95 \% \mathrm{TI})$ & $23,8(19,5-28,7)$ & $14,0(11,2-17,2)$ & $8,0(7,1-9,0)$ \\
\cline { 2 - 5 } & OR (95\% TI) & $3,6(2,7-4,8)^{* *}$ & $1,9(1,4-2,5)^{* *}$ & 1,0 \\
\hline
\end{tabular}

$* * \mathrm{p}<0,001$

Analizējot pusaudžu pašnāvības mēǵinājumus saistībā ar riskantu alkohola lietošanu, nesamēroto izredžu aprēḳins liecina, ka zēniem, kuri dz̄ives laikā piedzērušies 3 un vairāk reizes, ir statistiski nozīmīgi gandrīz divas reizes $(\mathrm{OR}=1,9)$ lielākas izredzes pašnāvības mēg̣inājumam, salīdzinot ar respondentiem, kuri atzīmējuši, ka dz̄ives laikā nav piedzērušies. 
Atšķirībā no domām par pašnāvību, netika novērotas statistiski nozīmīgi augstākas izredzes pašnāvības mēginājumam to zēnu vidū, kuri dzīves laikā piedzērušies 1-2 reizes (sk. 3.36. tab.).

Savukārt meitenēm, kuras dzīves laikā piedzērušās 1-2 reizes, vērojamas statistiski nozīmīgi 2,3 reizes lielākas izredzes pašnāvības mēǵinājumam, bet meitenēm, kuras atzīmējušas, ka dzīves laikā piedzērušās 3 un vairāk reizes, vērojamas trīs reizes lielākas izredzes pašnāvības mēǵinājumam, salīdzinot ar meitenēm, kuras atzīmējušas, ka dzīves laikā nav piedzērušās (sk. 3.36. tab.).

3.36. tabula

Pašnāvības mēḡinājumu saistība ar riskantu alkohola lietošanu

\begin{tabular}{|l|c|c|c|c|}
\hline \multirow{2}{*}{ Pašnāvības mēǵinājums } & \multicolumn{3}{|c|}{ Piedzeršanās dzìves laikā } \\
\cline { 3 - 5 } & & 3 un vairāk reizes & $1-2$ reizes & Nē \\
\hline \multirow{3}{*}{ Zēni } & $\mathrm{n}$ & 101 & 50 & 53 \\
\cline { 2 - 5 } & $\%(95 \% \mathrm{TI})$ & $8,2(6,8-9,9)$ & $5,0(3,8-6,6)$ & $4,4(3,4-5,8)$ \\
\cline { 2 - 5 } & OR (95\% TI) & $1,9(1,4-2,7) * *$ & $1,1(0,8-1,7)^{\mathrm{NS}}$ & 1,0 \\
\hline \multirow{3}{*}{ Meitenes } & $\mathrm{n}$ & 160 & 144 & 80 \\
\cline { 2 - 5 } & $\%(95 \% \mathrm{TI})$ & $14,7(12,7-16,9)$ & $11,8(10,1-13,7)$ & $5,4(4,4-6,7)$ \\
\cline { 2 - 5 } & OR (95\% TI) & $3,0(2,2-3,9)^{* *}$ & $2,3(1,7-3,1)^{* *}$ & 1,0 \\
\hline
\end{tabular}

** $\mathrm{p}<0,001 ;{ }^{\mathrm{NS}} \mathrm{p}>0,25$

Abās dzimumu grupās vērojama statistiski nozīmīga saistība starp pašnāvības mēgeinājumu un ikdienas smēḳēšanu - respondentiem - zēniem, kuri ikdienā smēḳē vērojamas 2,7 reizes lielākas izredzes pašnāvības mēǵinājumam, salīdzinot ar zēniem, kuri ikdienā nesmēķē (sk. 3.37. tab.).

Savukārt meitenēm, kuras ikdienā smēḳē, vērojamas 2,6 reizes lielākas izredzes pašnāvības mēgeinājumam, salīdzinot ar meitenēm, kuras ikdienā nesmēḳē (sk. 3.37. tab.).

3.37. tabula

Pašnāvības mēgeininājumu saistība ar ikdienas smēḳēšanu

\begin{tabular}{|l|c|c|c|}
\hline \multicolumn{2}{|c|}{ Pašnāvības mēǵinājums } & \multicolumn{2}{|c|}{ Ikdienas smēkēešana } \\
\cline { 2 - 4 } & & $\mathrm{Ja}$ & $\mathrm{Ne}$ \\
\hline \multirow{3}{*}{ Zēni } & $\mathrm{n}$ & 106 & 98 \\
\cline { 2 - 4 } & $\%(95 \% \mathrm{TI})$ & $10,3(8,6-12,3)$ & $4,1(3,3-4,9)$ \\
\cline { 2 - 4 } & OR $(95 \% \mathrm{TI})$ & $2,7(2,0-3,6)^{* *}$ & 1,0 \\
\hline \multirow{3}{*}{ Meitenes } & $\mathrm{n}$ & 151 & 236 \\
\cline { 2 - 4 } & $\%(95 \% \mathrm{TI})$ & $18,1(15,7-20,9)$ & $7,9(7,0-8,9)$ \\
\cline { 2 - 4 } & OR $(95 \% \mathrm{TI})$ & $2,6(2,1-3,2)^{* *}$ & 1,0 \\
\hline
\end{tabular}

$* * \mathrm{p}<0,001$ 
Abās dzimumu grupās vērojama arī statistiski nozīmīga saistība starp pašnāvības mēgeinājumu un narkotiku lietošanu dzīves laikā. Respondentiem - zēniem, kuri dzīves laikā lietojuši narkotikas, vērojamas gandrīz trīs reizes $(\mathrm{OR}=2,9)$ lielākas izredzes pašnāvības mēǵinājumam, salīdzinot ar zēniem, kuri dzīves laikā narkotikas nav lietojuši (sk. 3.38. tab.).

Savukārt meitenēm, kuras dz̄̄ves laikā lietojušas narkotikas, vērojamas 2,1 reizi lielākas izredzes pašnāvības mēginājumam, salīizinot ar meitenēm, kuras atzīmējušas, ka narkotikas nav lietojušas (sk. 3.38. tab.).

3.38. tabula

Pašnāvības mēǵinājumu saistība ar narkotiku lietošanu

\begin{tabular}{|l|c|c|c|}
\hline \multicolumn{2}{|c|}{ Pašnāvības mēǵinājums } & \multicolumn{2}{c|}{ Narkotiku lietošana dzīves laikā } \\
\cline { 2 - 4 } & & $\mathrm{Ja}$ & $\mathrm{Ne}$ \\
\hline \multirow{3}{*}{ Zēni } & $\mathrm{n}$ & 114 & 87 \\
\cline { 2 - 4 } & $\%(95 \% \mathrm{TI})$ & $10,2(8,5-12,1)$ & $3,8(3,1-4,6)$ \\
\cline { 2 - 4 } & OR (95\% TI) & $2,9(2,2-3,9)^{* *}$ & 1,0 \\
\hline \multirow{3}{*}{ Meitenes } & $\mathrm{n}$ & 144 & 245 \\
\cline { 2 - 4 } & $\%(95 \% \mathrm{TI})$ & $16,1(13,8-18,7)$ & $8,4(7,4-9,5)$ \\
\cline { 2 - 4 } & OR (95\% TI) & $2,1(1,7-2,6)^{* *}$ & 1,0 \\
\hline
\end{tabular}

$* * \mathrm{p}<0,001$

3.15. un 3.16. attēlos redzama apkopojoša informācija par nesamērotajām, statistiski nozīmīgajām izredzēm pašnāvības mēg̣inājumam saistībā ar pētītajiem individuālajiem faktoriem zēniem un meitenēm. Abās dzimumu grupās sakarības ar visiem pētītajiem individuālajiem faktoriem ir statistiski nozīmīgas, taču zēnu vidū netika konstatēta statistiski nozīmīga saistība starp pašnāvības mēginājumu un riskanta alkohola lietošanas kategoriju " 1 2 reizes".

Zēnu vidū salīdzinoši augstākās izredzes pašnāvības mēgeinājumam vērojamas respondentiem ar zemu pašcieṇas līmeni $(\mathrm{OR}=7,9)$, augstu depresijas simptomu līmeni $(\mathrm{OR}=6,4)$ un neapmierinātību ar savu veselības stāvokli $(\mathrm{OR}=4,5)$ (sk. 3.15. att.).

Arī meiteṇu vidū individuālie faktori, kas nosaka augstākās izredzes pašnāvības mēginājumam, ir augsts depresijas simptomu līmenis $(\mathrm{OR}=4,8)$, zems pašcieņas līmenis (OR $=3,8)$ un neapmierinātība ar savu veselības stāvokli $(\mathrm{OR}=3,6)$ (sk. 3.16. att.). 


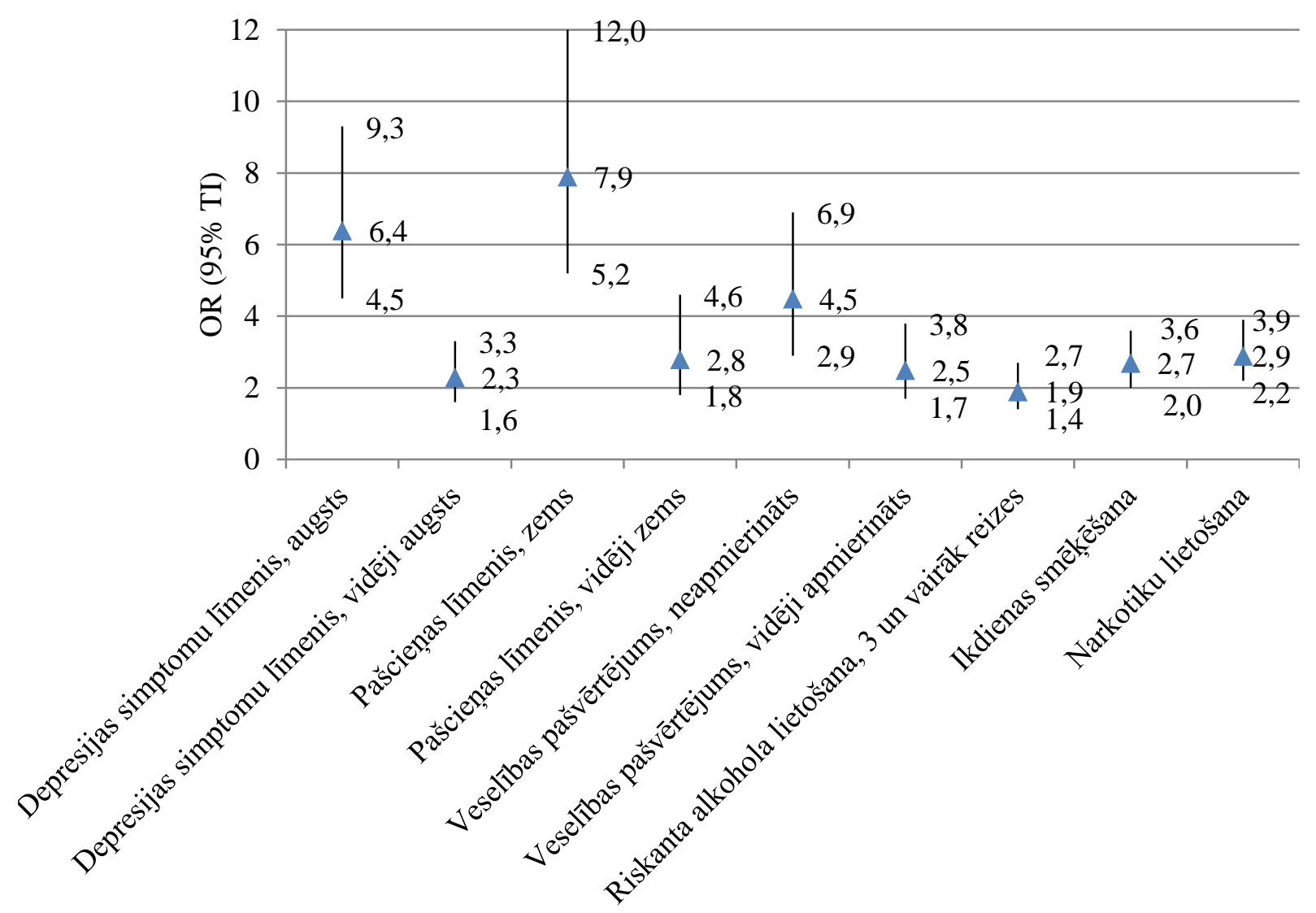

3.15. attēls. Nesamērotās izredzes pašnāvības mēgéinājumam saistībā ar pētītajiem ar individuālajiem faktoriem zēniem

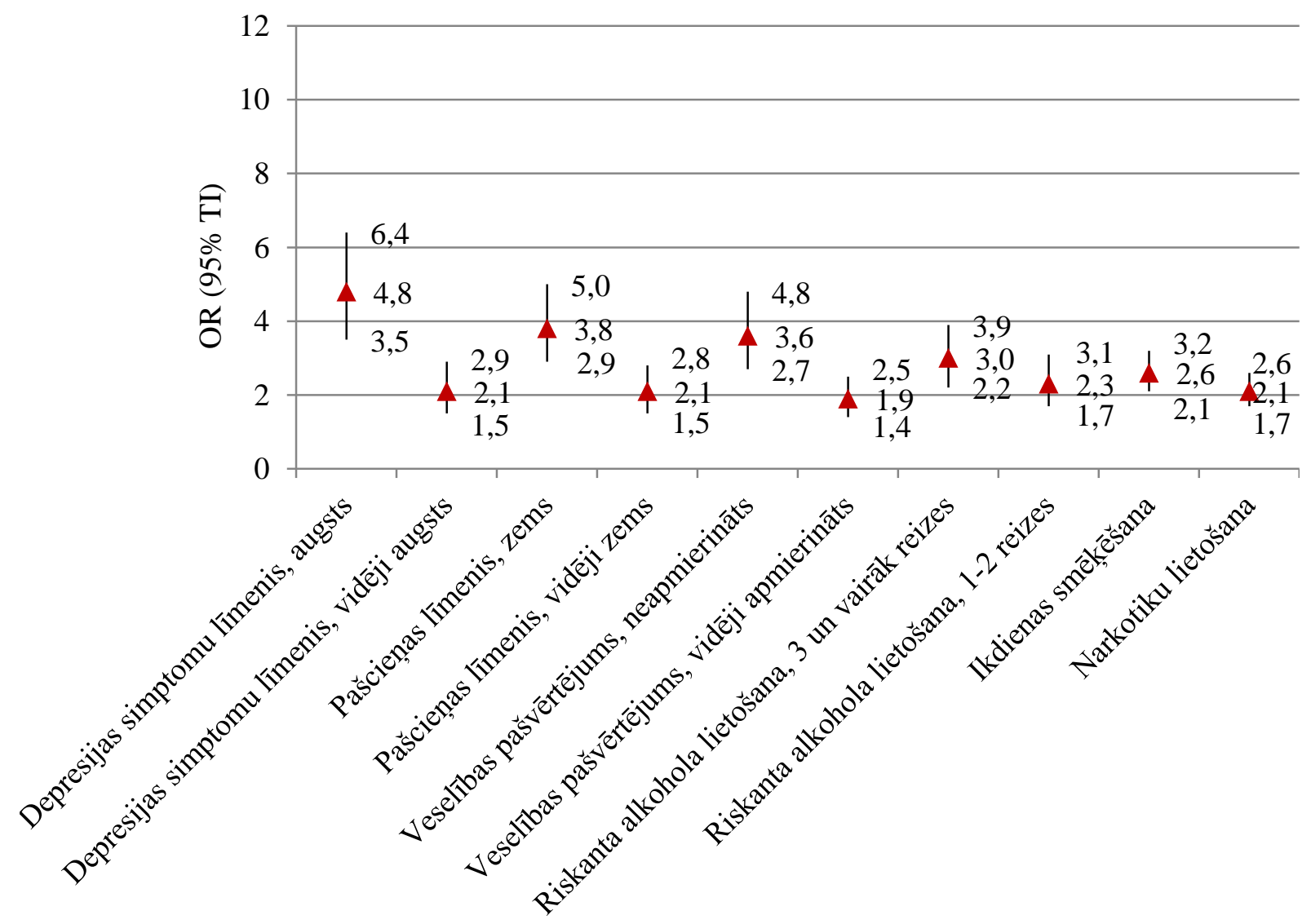

3.16. attēls. Nesamērotās izredzes pašnāvības mēgeinājumam saistībā ar pētītajiem ar individuālajiem faktoriem meitenēm 
Daudzfaktoru log̣istiskās regresijas modeḷos tika analizēta pētīto individuālo faktoru neatkarīgā ietekme uz pusaudža pašnāvības mēǵinājumu dzimumu grupās.

Kolinearitātes pārbaude starp neatkarīgajiem main̄̄gajiem dzimumu grupās liecina, ka kolinearitāte netraucē izdarīt secinājumus par regresijas modeḷos iekḷauto neatkarīgo mainīgo ietekmi uz atkarīgo mainīgo - pašnāvības mēǵinājumu: zēniem Tolerances testa vērtības main̄̄gajiem nav zemākas par 0,7 un VIF vērtības nepārsniedz 1,4. Savukārt meitenēm Tolerances testa vērtības mainīgajiem nav zemākas par 0,9 un VIF vērtības nepārsniedz 1,4. Neatkarīgo mainīgo savstarpējās korelācijas aprakstītas 3.5.1. nodaḷā.

Sākotnēji dzimumu grupās tika veikta katra pētītā individuālā faktora samērošana ar respondenta vecumu, pēc tam modelī 1 katrs no pētītajiem faktoriem tika samērots ar respondenta vecumu un gímenes materiālo stāvokli, savukārt modelī 2 katrs no pētītajiem faktoriem tika samērots ar respondenta vecumu, gímenes materiālo stāvokli un citiem pētītajiem pusaudža individuālajiem faktoriem.

Pēc sākotnēji veiktās katra pētītā faktora samērošanas ar respondenta vecumu iegūtie rezultāti liecina, ka izredžu attiecību izmaiņas, salīdzinot ar nesamērotajiem rādītājiem, ir: $0,0 \%-5,3 \%$ zēniem un $0,0 \%-4,3 \%$ meitenēm.

Pēc modelī 1 veiktās katra pētîtā faktora samērošanas ar respondenta vecumu un ǵimenes materiālo stāvokli iegūtie rezultāti liecina, ka izredžu attiecību izmaiņas, salīdzinot ar nesamērotajiem rādītājiem, ir: $1,3 \%-6,2 \%$ zēniem un $0,0 \%-5,3 \%$ meitenēm un visas sakarības, kuras bija statistiski nozīmīgas vienfaktora analīzē, saglabājas statistiski nozīmīgas.

Pēc modelī 2 veiktās pētīto faktoru savstarpējās samērošanas ar respondenta vecumu, gimenes materiālo stāvokli un citiem pētītajiem individuālajiem faktoriem, katra atsevišķā individuālā faktora neatkarīgais efekts uz pašnāvības mēgināājumu samazinās abos dzimumos (sk. 3.39. tab.).

Augsts depresijas simptomu līmenis pēc samērošanas ar respondenta vecumu un ǵimenes materiālo stāvokli zēniem pašnāvības mēǵinājuma izredzes palielina gandrīz septiṇas reizes $(\mathrm{OR}=6,8)$, savukārt vidēji augsts depresijas simptomu līmenis $-2,4$ reizes, bet pēc samērošanas ar respondenta vecumu, gímenes materiālo stāvokli un citiem pētītajiem individuālajiem faktoriem izredzes pašnāvības mēginājumam ir attiecīgi 3,5 un divas reizes augstākas, salīdzinot ar zēniem, kuru depresijas simptomu līmenis ir zems. Savukārt meiteṇu vidū augsts depresijas simptomu līmenis pēc samērošanas ar respondenta vecumu un ǵimenes materiālo stāvokli pašnāvības mēǵinājuma izredzes palielina gandrīz piecas reizes $(\mathrm{OR}=4,8)$, vidēji augsts depresijas simptomu līmenis - 2,1 reizi, bet pēc samērošanas ar respondenta vecumu, ğimenes materiālo stāvokli un citiem individuālajiem faktoriem izredzes pašnāvības 
mēǵinājumam ir attiecīgi gandrīz trīs $(\mathrm{OR}=2,8)$ un 1,7 reizes augstākas, salīdzinot ar meitenēm, kuru depresijas simptomu līmenis ir zems (sk. 3.39. tab.).

Zems pašcieņas līmenis pēc samērošanas ar respondenta vecumu un ǵimenes materiālo stāvokli zēniem pašnāvības mēgeinājuma izredzes palielina astoṇas reizes, savukārt vidēji zems pašcieņas līmenis - gandrīz trīs reizes $(\mathrm{OR}=2,9)$, bet pēc samērošanas ar respondenta vecumu, gimenes materiālo stāvokli un citiem pētītajiem individuālajiem faktoriem izredzes pašnāvības mēǵinājumam ir attiecīgi 5,1 un 2,4 reizes augstākas, salīdzinot ar zēniem, kuru pašcieņas līmenis ir augsts. Savukārt meiteṇu vidū zems pašcien,as līmenis pēc samērošanas ar respondenta vecumu un gimenes materiālo stāvokli pašnāvības mēǵinājuma izredzes palielina 3,7 reizes, vidēji zems pašcieņas līmenis - divas reizes, bet pēc samērošanas ar respondenta vecumu, gimenes materiālo stāvokli un citiem individuālajiem faktoriem izredzes pašnāvības mēǵinājumam ir attiecīgi 2,3 un 1,6 reizes augstākas, salīdzinot ar meitenēm, kuru pašcieņas līmenis ir augsts (sk. 3.39. tab.).

Neapmierinātība ar veselības stāvokli pēc samērošanas ar respondenta vecumu un ǵimenes materiālo stāvokli zēniem pašnāvības mēǵinājuma izredzes palielina 4,6 reizes, savukārt vidēja apmierinātība - 2,6 reizes, salīdzinot ar zēniem, kuri ar savu veselības stāvokli ir apmierināti, savukārt pēc samērošanas ar respondenta vecumu, gimenes materiālo stāvokli un citiem pētītajiem individuālajiem faktoriem zēniem, kuri ir neapmierināti ar savu veselības stāvokli, vērojamas 2,1 reizi lielākas izredzes pašnāvības mēginājumam, taču attiecībā uz vidēju apmierinātību ar veselības stāvokli zēniem saistība nav statistiski nozīmīga. Savukārt meiteṇu vidū neapmierinātība ar veselības stāvokli pēc samērošanas ar respondenta vecumu un gimenes materiālo stāvokli pašnāvības mēginājuma izredzes palielina 3,5 reizes, vidēja apmierinātība - gandrīz divas reizes $(\mathrm{OR}=1,8)$, bet pēc samērošanas ar respondenta vecumu, ǵimenes materiālo stāvokli un citiem individuālajiem faktoriem izredzes pašnāvības mēǵinājumam neapmierinātības ar veselības pašvērtējumu gadījumā ir 2,1 reizi augstākas nekā meitenēm, kuras ar veselības stāvokli ir apmierinātas, taču statistiski nozīmīgi lielākas izredzes pašnāvības mēǵinājumam vidējas apmierinātības ar veselības stāvokli gadījumā meitenēm netika konstatētas (sk. 3.39. tab.).

Riskanta alkohola lietošana 3 un vairāk reizes dzīves laikā pēc samērošanas ar respondenta vecumu un ǵimenes materiālo stāvokli zēniem pašnāvības mēǵinājuma izredzes palielina divas reizes, salīdzinot ar zēniem, kuri dzīves laikā riskanti alkoholu nav lietojuši, pašnāvības mēǵinājuma saistība ar riskantu alkohola lietošanu 1-2 reizes zēniem nav statistiski nozīmīga. Pēc samērošanas ar respondenta vecumu, ǵimenes materiālo stāvokli un citiem pētītajiem individuālajiem faktoriem pašnāvības mēǵinājuma saistība ar riskantu alkohola lietošanu zēniem vairs nav statistiski nozīmīga. Savukārt meiteņu vidū riskanta 
alkohola lietošana 3 un vairāk reizes dzīves laikā pēc samērošanas ar respondenta vecumu un ǵimenes materiālo stāvokli pašnāvības mēg̣inājuma izredzes palielina gandrīz trīs reizes (OR = 2,9), riskanta alkohola lietošana 1-2 reizes - 2,3 reizes, bet pēc samērošanas ar respondenta vecumu, gimenes materiālo stāvokli un citiem individuālajiem faktoriem izredzes pašnāvības mēǵinājumam meitenēm abās riskanta alkohola lietošanās kategorijās ir gandrīz divas $(\mathrm{OR}=1,8)$ augstākas, salīdzinot ar meitenēm, kuras dz̄ives laikā riskanti alkoholu nav lietojušas (sk. 3.39. tab.).

Ikdienas smēķēšana pēc samērošanas ar respondenta vecumu un gimenes materiālo stāvokli zēniem pašnāvības mēg̣inājuma izredzes palielina gandrīz trīs reizes $(\mathrm{OR}=2,8)$, bet pēc samērošanas ar respondenta vecumu, gimenes materiālo stāvokli un citiem pētītajiem individuālajiem faktoriem - 2,3 reizes, salīdzinot ar zēniem, kuri ikdienā nesmēḳē. Meiteņu vidū pēc samērošanas ar respondenta vecumu un ǵimenes materiālo stāvokli ikdienas smēḳēšana pašnāvības mēǵinājuma izredzes palielina 2,5 reizes, bet pēc samērošanas ar respondenta vecumu, ǵimenes materiālo stāvokli un citiem pētītajiem individuālajiem faktoriem - gandrīz divas reizes $(\mathrm{OR}=1,8)$, salīdzinot ar meitenēm, kuras ikdienā nesmēḳē (sk. 3.39. tab.).

Narkotiku lietošana dzīves laikā pēc samērošanas ar respondenta vecumu un ǵimenes materiālo stāvokli zēniem pašnāvības mēǵinājuma izredzes palielina trīs reizes, bet pēc samērošanas ar respondenta vecumu, gimenes materiālo stāvokli un citiem pētītajiem individuālajiem faktoriem - 1,7 reizes, salīdzinot ar zēniem, kuri marihuānu/hašišu, amfetamīnu, LSD/citus halucinogēnus, kreku, kokaīnu, heroīnu, ekstazī un/vai spice nav lietojuši. Meiteņu vidū pēc samērošanas ar respondenta vecumu un gimenes materiālo stāvokli narkotiku lietošana dzīves laikā pašnāvības mēǵinājuma izredzes palielina 2,1 reizi, salīdzinot ar meitenēm, kuras marihuānu/hašišu, amfetamīnu, LSD/citus halucinogēnus, kreku, kokaīnu, heroīnu, ekstazī un/vai spice dzīves laikā nav lietojušas, taču pēc samērošanas ar respondenta vecumu, ğimenes materiālo stāvokli un citiem pētītajiem individuālajiem faktoriem saistība ar pašnāvības mēǵinājumu vairs nav statistiski nozīmīga (sk. 3.39. tab.). 


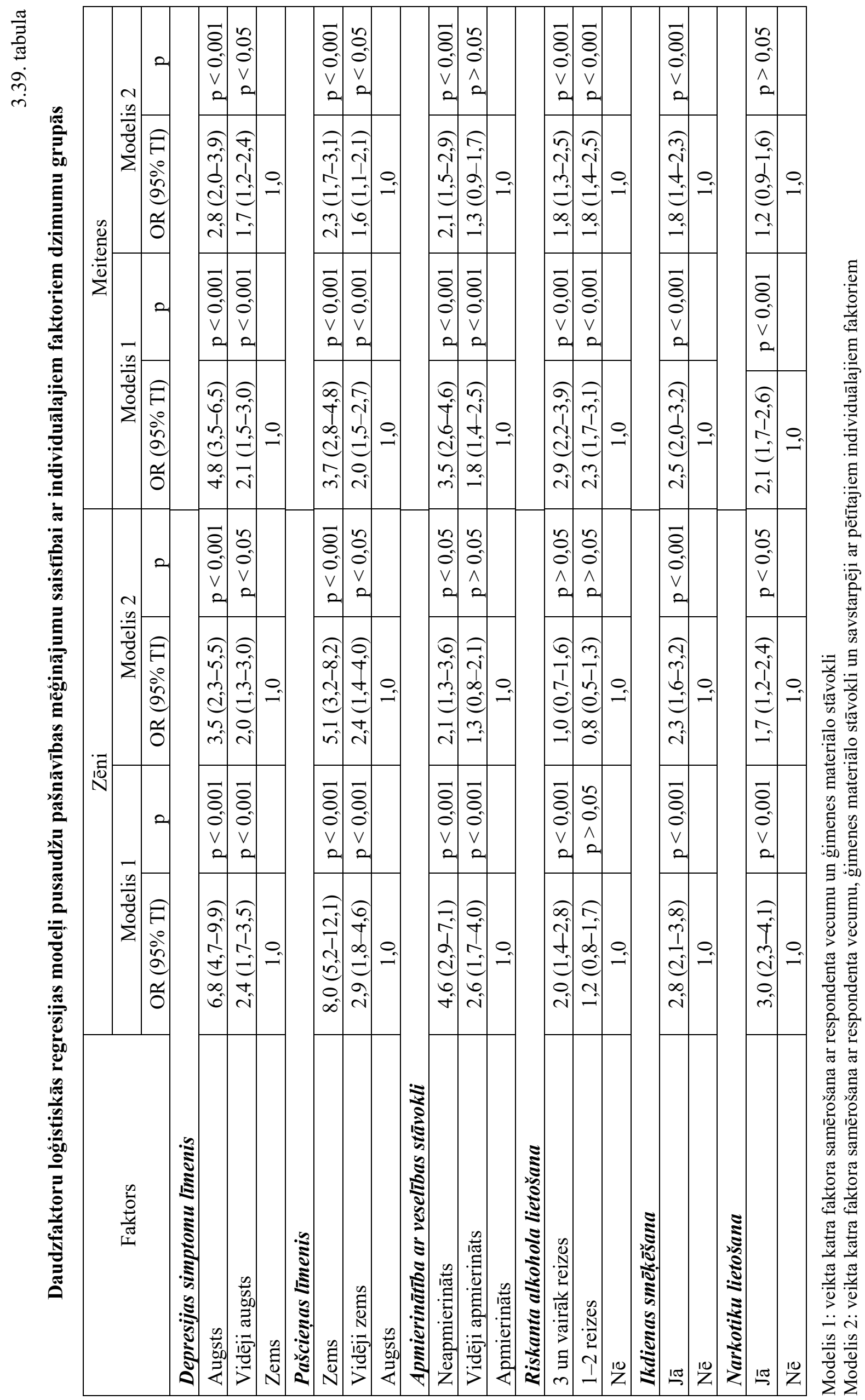




\section{DISKUSIJA}

\subsection{Pašnāvnieciskās uzvedības izplatība pusaudžu sociāldemogrāfiskajās grupās}

Promocijas darbā iegūtie rezultāti liecina, ka domas par pašnāvību dzīves laikā, jeb pārdomātu konkrētu veidu, vietu vai rīcību pašnāvības izdarīšanai atzīmējuši 15,7\% Latvijas 14-17 gadus veco pusaudžu - nedaudz vairāk kā katrs desmitais zēns $(11,7 \%)$ un gandrīz katra piektā meitene (19,4\%). N̦emot vērā zinātniskajā literatūrā vērojamās būtiskās atškirīibas domu par pašnāvību definēšanā un faktu, ka jautājums konstruēts tieši aktīvu domu par pašnāvību noskaidrošanai, kas ietver domas par rīcību savas dzīves izbeigšanai, ietverot metodes identificēšanu, plāna esamību vai nodomu atbilstoši rīkoties (Turecki and Brent, 2016), ir apgrūtināta iegūtās domu par pašnāvību izplatības precīza salīdzināšana ar citās valstīs iegūtajiem rezultātiem. Pēc vienotas metodologijas atbilstošā vecuma grupā veiktā pētījumā Beḷgijāā, Anglijā, Ungārijā, İrijā, Nīderlandē, Norvēǵijā un Austrālijā tika iegūts līdzịgs izplatîbas rādītājs - 14,6\% (9,2\% zēniem un 20,3\% meitenēm), tomēr šajā pētījumā analizētas domas par paškaitējumu, kas ietver pašnāvnieciskus aktu gan ar, gan bez vēlmes izdarīt pabeigtu pašnāvību, tomēr šajā pētījumā ir definēti konkrēti paškaitējuma veidi (Madge et al., 2011). No otras puses, cilvēka, jo īpaši pusaudža, un vēl jo vairāk domu par paškaitējumu gadījumā pašnāvnieciskais nodoms var būt ambivalents, neizšķirot skaidru nodomu dzīvot vai mirt (WHO, 2014a), kas liecina arī par iespēju arī šos rādītājus izmantot salīdzinājumam, jo ir maz ticams, ka pusaudzis, atbildot uz jautājumu, ir ṇēmis vērā pētnieku un zinātnieku apsvērumus par atšķirībām jēdzienu definīcijās un detalizēti analizējis savu vēlmi mirt pārdomātā pašnāvības veikšanas vietā, noteiktā veidā, vai apzinātas rīcības rezultātā. Tāpat arī iegūtie domu par pašnāvību izplatības rādītāji ir ievērojami zemāki nekā līdzīgā vecuma grupā veiktajā pētījumā 17 Eiropas valstīs, kurā vaicāts vai respondents dzīves laikā ir domājis darìt sev pāri un iegūti teju uz pusi augstāki izplatības rādītāji - 30,8\% (20,2\% zēniem un 41,2\% meitenēm) (Kokkevi et al., 2012), kas, visticamāk, liecina nevis par zemākiem domu par pašnāvību izplatîbas rādītājiem Latvijāa, bet gan par promocijas darbā izmantotās domu par pašnāvību gadījuma definīcijas salīdzinošo precizitāti, kas uzskatāma par promocijas darbā izmantotās definīcijas salīdzinošo priekšrocību

Savukārt dzīves laikā veiktu mēginājumu izdarīt pašnāvību atzīmējuši 8,2\% pusaudžu - 5,9\% zēnu un 10,2\% meiteṇu. Arī attiecībā uz pašnāvības mēǵinājumu vērojamas atšḳirības gadījuma definīcijās, tomēr šīs atškirības nav tik izteiktas kā domu par pašnāvību gadījumā, tādēḷ ir vieglāk veikt salīdzinājumu starp dažādām valstīm. Attiecībā uz pašnāvības mēg̣inājumu būtiskākas atškirīibas izplatības radītājos zinātniskajā literatūrā vērojamas 
atkarībā no tā vai veikta anonīma anketēšana, vai pusaudži uz jautājumu par pašnāvības mēǵinājumu atbildējuši tiešajās intervijās - pētījuma dati liecina, ka anonīmās anketās pusaudži par pašnāvības mēg̣inājumiem ziņo biežāk nekā tiešajās intervijās (Safer, 1997), kas liecina, ka anonīmās aptaujās pusaudži ir atklātāki par šāda veida pieredzi. Attiecīgi arī pusaudžu pašu ziņoto pašnāvības mēginājumu izplatība analizētajos zinātniskās literatūras avotos variē atkarībā no izmantotās pētījuma metodoloǵijas un analizētās pusaudžu vecuma grupas - 2,9\% līdz 14,4\% kopējos izplatības rādītājos, 1,5\% līidz 8,4\% zēniem un 2,5\% līdz 17,9\% meitenēm (Kokkevi et al., 2012; Kokkevi et al., 2011; Nock et al., 2013; Joe et al., 2009; Hu et al., 2015; Zarrouq et al., 2015). Salīdzinoši precīzākais pusaudžu pašu ziņoto pašnāvības mēginājumu izplatības salīdzinājums ar situāciju citās valstīs iespējams, analizējot šos datus par tām valstīm, kurās arī veikts ESPAD pētījums ar iekḷautu psihosociālo moduli, t.sk. jautājumu par pusaudžu pašnāvības mēgeinājumiem. Lai arī starptautiski tiek salīdzināti dati par 15-16 gadus veciem pusaudžiem, dati par 2007. gadu liecina, ka šajās 17 Eiropas valstīs vidējais pašnāvības mēǵinājuma izplatība rādītājs ir 11\% (8\% zēniem un 14\% meitenēm) (Hibell et al., 2009) un mediāna 10,5\% (6,9\% zēniem un 13,7\% meitenēm) (Kokkevi et al., 2012), kas liecina, ka gan kopējais izplatības rādītājs, gan izplatība abās dzimumu grupās Latvijā ir salīdzinoši zemāka, tomēr, ņemot vērā, ka šiem rādītājiem ir tendence gadu gaitā mainīties (Kokkevi et al., 2011), precīzākam salīdzinājumam būtu nepieciešami 2011. gada dati par situāciju citās valstīs. Analizējot pašnāvības mēǵinājumu izplatības datus nacionālā kontekstā, arī jāsecina, ka 2011. gadā izplatības rādītāji ir samazinājušies, jo 2007. gadā Latvijas rādītājs bija 14,2\% (10,1\% zēniem un 18,1\% meitenēm) (Kokkevi et al., 2012). N̦emot vērā faktu, ka salīdzinājums ir ar pusaudžu vecuma grupu 15-16 gadi un divu gadu ietvaros nav iespējams spriest par tendencēm dinamikā, nākotnē nepieciešams sekot izplatības rādītājam plašākā vecuma grupā. Neskatoties uz to, ka arī daudzos citos pētījumos pašnāvības mēginājuma noteikšanai tiek izmantots līdzīgs jautājums, no vienas puses pašnāvības mēginājuma gadījuma interpretācijas mazinātu jautājuma konkretizēšana, tomēr jāṇem vērā, ka konkrētu metožu vai veidu norādīšana jautājumā, iespējams, var saistīties ar atdarinošo pašnāvības mēǵinājumu risku (WHO, 2008), jo īpaši pusaudžu populācijā un jo īpaši apstākḷos, kad tiek anketēts liels skaits pusaudžu.

Jau iepriekš minētie, promocijas darbā iegūtie dati par pašnāvnieciskās uzvedības izplatību dzimuma grupās liecina, ka meitenes gan domas par pašnāvību, gan pašnāvības mēǵinājumus atzīmē biežāk nekā zēni - par šo faktu liecina arī teju visi 1.2.1 un 1.2.2. nodaḷās analizētie zinātniskās literatūras avoti. Likumsakarīgs ir jautājums par šo atškirīìu iemesliem, jo īpaši ņemot vērā faktu, ka pabeigtas pašnāvības gadu no gada biežāk izdara zēni (Šica, Pulmanis un Taube, 2017). Zinātniskajā literatūrā šì situācija tiek definēta kā dzimuma 
paradokss (angl. - gender paradox) (Tsirigotis, Gruszczynski and Tsirigotis, 2011; Rhodes et al., 2014; Beautrais, 2002), kas tiek skaidrots ar sieviešu izteiktāku ievainojamību psihopatalogiju un psihosociālu stresoru gadījumā (Vijayakumar, 2015), kas sieviešu un meiteņu vidū ir arī izplatîtākas iepretim faktam, ka sievietes izvēlas mazāk nāvējošākas pašnāvības izdarīšanas metodes, kas vairāk piesaista uzmanību sievietes psihoemocionālajām ciešanām un mazāk ir saistītas ar reālu vēlmi mirt. Citi skaidrojumi saistīti arī ar sieviešu izteiktāko vēlmi runāt par savām problēmām un meklēt palīdzību, piemēram, apmeklēt ārstu vai zvanīt uz krīzes tālruniem (Beautrais, 2002).

Tāpat promocijas darbā noskaidrots, ka augstāka domu par pašnāvību izplatība ir vecākajā analizētajā pusaudžu vecuma grupā, proti, 16-17 gadi, salīdzinot ar vecuma grupu 14-15 gadi. Domu par pašnāvību un pašnāvības mēǵinājumu izplatības pieauguma tendence līdz ar pusaudža vecuma grupas palielināšanos novērota arī citos pētījumos (Zubrick et al., 2016; Wolitzky-Taylor et al., 2010) (promocijas darba ietvaros attiecībā uz pašnāvības mēǵinājumiem izplatības atšķirības vecuma grupās nebija statistiski nozīmīgas), taču jāṇem vērā, ka izvēlēto pašnāvnieciskās uzvedības izplatības rādītāju - mūža prevalenci teorētiski var ietekmēt arī pusaudža dzīves garums, kas, neskatoties uz salīdzinoši nelielo vecuma grupu intervālu, tomēr neḷauj izdarīt precīzus secinājumus par atšķirībām pašnāvnieciskās uzvedības izplatīiā vecuma analizētajās vecuma grupās.

Darbā iegūtie rezultāti liecina, ka augstāka domu par pašnāvību izplatība vērojama arī to zēnu un meiteņu vidū, kuri savas gimenes materiālo stāvokli salīdzinot ar citām ǵimenēm Latvijā novērtējuši kā sliktāku, meitenēm šajā materiālā stāvokḷa vērtējuma kategorijā ir arī augstāka pašu ziṇoto pašnāvības mēginājumu izplatība. Kopumā iegūtie rezultāti saskan ar ārvalstu pētījumos noskaidroto (Samm et al., 2010; Zubrick et al, 2016; Kokkevi et al., 2012), tomēr, vērtējot retrospektīvi, 2011. gadā, kad tika veikta anketēšana, Latvijas gímenes joprojām izjuta 2008.-2010. gada Latvijas finanšu un pārvaldes krīzes sekas. Šajā gadījumā, iespējams, par pētījuma priekšrocību uzskatāms fakts, ka tika izmantots pusaudža subjektīvais, nevis objektīvais gimenes materiālā stāvokḷa vērtējums, kas reprezentē arī sociālekonomisko situāciju saistīto personīgo pieredzi (Singh-Manoux, Adler and Marmot, 2003) un teorētiski rodas salīdzinot savas ǵimenes materiālo stāvokli ar citām ǵimenēm konkrētajā kopienā (dzīves vidē). N̦emot vērā daudzos ar materiālo stāvokli saistītos aspektus, būtu lietderīgi nākotnē analizēt arī to, cik cieša ir saistība starp pašnāvniecisko uzvedību un zemu gimenes materiālo stāvokli arī šobrīd - vairākus gadus pēc Latvijas finanšu un pārvaldes krīzes.

Tāpat promocijas darbā noskaidrots, ka no respondentiem, kuri atzīmējuši pašnāvības mēǵinājumu dzīves laikā, 66,5\% atzīmējuši arī domas par pašnāvību, savukārt no 
respondentiem, kuri atzīmējuši domas par pašnāvību, 34,4\% atzīmējuši arī pašnāvības mēǵinājumu. 17 Eiropas valstīs veikta pētījuma par 15-16 gadus veciem pusaudžiem dati liecina, ka no respondentiem, kuri atzīmējuši pašnāvības mēǵinājumu dzīves laikā, 80,9\%93,9\% (atkarībā no valsts) atzīmējuši arī domas par paškaitējumu, savukārt no respondentiem, kuri atzīmējuši domas par paškaitējumu, vidēji trešadaḷa atzīmējuši arī pašnāvības mēǵinājumu (Kokkevi et al., 2012). Iepriekš minētajā pētījumā gan analizētas domas par paškaitējumu, taču iegūtie rezultāti vedina domāt, ka daḷa pašnāvības mēǵinājumi pusaudžu vidū notiek arī spontāni, vai mirkḷa iespaidā, bez ilgstošas nodoma apsvēršanas. Latvijas 1864 gadus veco iedzīvotāju vidū veiktā pētījumā savukārt noskaidrots, ka no respondentiem, kas atzīmējuši dažādus pašnāvnieciskās uzvedības veidus, turpinoša secība no zemāka uz augstāka riska pašnāvniecisku uzvedību vērojama 79.6\% gadījumu (Rancāns et al., 2016).

\subsection{Pašnāvnieciskā uzvedība un ar gimenes vidi saistītie faktori}

Promocijas darbā iegūtie rezultāti liecina, ka nedz̄ivošana ar abiem biolog̣iskajiem vecākiem palielina gan domu par pašnāvību, gan pašnāvības mēǵinājuma izredzes. Līdzīgi rezultāti iegūti arī citos pētîjumos (Zaborskis, Sirvyte and Zemaitiene, 2016; Laukkanen et al., 2009; Nock et al., 2013; Kokkevi et al., 2012; Kokkevi et al., 2011; Morey et al., 2008; Wagner, Cole and Schwartzman, 1995; Ponnet et al., 2005). Tikai meitenēm pēc samērošanas ar vecumu, gimenes materiālo stāvokli un citiem pētītajiem ar gimenes vidi saistītajiem faktoriem saistība ar domām par pašnāvību nebija statistiski nozīmīga. Pētījumos noskaidrots, ka sakarības ciešumu ietekmē vecāku-bērnu attiecību kvalitāte, finansiālā situācija ǵimenēs, kur bērnu audzina viens no vecākiem, un saṇemtās mīlestības apjoms ǵimenē, kam var būt būtiskāka loma par gímenes struktūru (Susukida, Wilcox and Mendelson, 2016; Turunen, 2013), tomēr fakts, ka promocijas darbā samērošana ar ǵimenes materiālo stāvokli saistību ar pašnāvniecisko uzvedību abās dzimumu grupās ietekmēja nebūtiski un pēc samērošanas ar citiem pētītajiem ar ǵimenes vidi saistītajiem faktoriem (t.sk. vecāku emocionālo atbalstu) saistība vairs nebija statistiski nozīmīga tikai meitenēm attiecībā uz domām par pašnāvību liecina, ka pastāv vēl vairāki citi padziḷinātas izpētes vērti "mehānismi”, kas pusaudžus, kuri nedz̄ivo ar abiem bioloǵiskajiem vecākiem, pakḷauj augstākam pašnāvnieciskās uzvedības riskam, piemēram, drošības un piederības sajūtas trūkums, kas var veicināt riska uzvedību (Brook et al., 2012). Iegūtie rezultāti aktualizēe politikas līmeṇa risinājumu nepieciešamību, kas veicina finansiāla un cita veida atbalstu ǵimenēm, lai vecāki neizceḷotu no valsts, piemēram, finansiālu apsvērumu vadīti. 
Iegūtie rezultāti liecina, ka abu pētīto pašnāvnieciskās uzvedības veidu izredzes abos dzimumos palielina arī vecāku emocionālā atbalsta trūkums, turklāt izredzes pašnāvnieciskajai uzvedībai ir augstākas gan pusaudžiem, kuri vecāku emocionālo atbalstu saņem reti/nekad, gan tiem, kuri šo atbalstu saņem tikai dažreiz (izņemot kategorijas “dažreiz" saistîbu ar pašnāvības mēginājumu zēniem) un šī saistība ar abiem pētītajiem pašnāvnieciskās uzvedības veidiem saglabājas statistiski nozīmīga ar̄̄ pēc samērošanas ar vecumu, ǵimenes materiālo stāvokli un citiem pētītajiem ar ğimenes vidi saistītajiem faktoriem. Iegūtie dati ḷauj secināt, ka "īstajā brīdī” pieejamam vecāku emocionālajam atbalstam var būt nozīmīga loma pašnāvnieciskās uzvedības profilaksē un šī atbalsta pilnīgai nepieejamībai iespējamas vēl būtiskākas negatīvas sekas. Līdzīgi rezultāti iegūti arī citās valstīs veiktos pētījumos (Zaborskis, Sirvyte and Zemaitiene, 2016; Mark et al., 2013; Brunner et al., 2014). Iegūtie rezultāti liecina, ka papildus vecāku lomas un izpratnes veicināšanai par emocionālā atbalsta sniegšanas noz̄imi bērnam, nozīmīga loma ir arī citu atbalsta sistēmu (savstarpēji atbalstošas attiecības vienaudžu vidū, psihologu un pedagogu atbalsts skolā, krīzes un uzticības tālruṇi u. c.) stiprināšanai gadījumos, kad vecāku emocionālais atbalsts pusaudzim nav pieejams.

Abās dzimumu grupās gan domu par pašnāvību, gan pašnāvības mēginājuma izredzes ir augstākas Latvijas pusaudžiem ar pašnāvniecisku pieredzi ğimenē, jeb no gimenēm, kurās kāds no ğimenes locekḷiem ir izdarījis pašnāvību un/vai pašnāvības mēginājumu. Turklāt šī faktora efekts uz pašnāvnieciskās uzvedības izredzēm ir ievērojams, piemēram, zēniem pašnāvnieciska pieredze ğimenē palielina izredzes domām par pašnāvību 13,5 reizes pirms un 8,5 reizes pēc samērošanas ar vecumu, ǵimenes materiālo stāvokli un citiem ar ǵimenes vidi saistītajiem faktoriem, turklāt pašnāvnieciska pieredze g̊imenē arī pēc samērošanas ir faktors, kas saistīts ar augstākajām izredzēm pašnāvības mēginājumam, salīdzinot ar citiem pētītajiem, ar ǵimenes vidi saistītajiem faktoriem. Pašnāvnieciskas pieredzes ǵimenē saistība ar pašnāvniecisku uzvedību iezīmējas arī vairākos citos pētījumos (Tomori et al., 2001; Portzky, De Wilde and van Heeringen, 2008; Nanayakkara et al., 2013; Brent and Mann, 2006; Chan et al., 2018; Cerel and Roberts, 2005). Novērotās saistības skaidrojums varētu būt balstīts Sociālās mācīšanās teorijā (angl. - Social Learning Theory), kurā uzsvērts, ka jauni uzvedības veidi tiek iegūti (apgūti) caur tiešu pieredzi vai novērojot citu rīcību (Bandura, 1971) - šāda hipotēze izteikta arī citā pētījumā (Chan et al., 2018). Pēdējos gados daḷa sakarības zinātniskajā literatūrā tiek skaidrota ar̄̄ ar ǵenētiskajiem faktoriem, kas var "pārnest" suicidalitāti gan tiešā veidā, gan caur impulsīvi agresīvu uzvedību un garastāvokḷa traucējumiem, kas attiecīgi var provocēt pašnāvniecisku uzvedību (Turecki and Brent, 2016). Neskatoties uz saistības skaidrojumiem, iegūtie dati liecina, ka pusaudži ar pašnāvniecisku 
pieredzi ǵimenē ir nozīmīga riska grupa pašnāvnieciskai uzvedībai ar attiecīgi augstāku risku arī pabeigtai pašnāvībai, kas jāṇem vērā profilakses programmās, kā arī veidojot skrīninga “instrumentus”, kas diferencē pusaudžus paaugstināta riska grupās tālākai intervencei.

Promocijas darbā iegūtie rezultāti liecina, ka pašnāvnieciskās uzvedības izredzes abās dzimumu grupās palielina arī fiziska vardarbība ğimenē un saistība saglabājas statistiski nozīmīga arī pēc samērošanas ar vecumu, ǵimenes materiālo stāvokli un citiem pētîtajiem ar ǵimenes vidi saistītajiem faktoriem par spīti faktam, ka apstiprinošā atbilde uz apgalvojumu “Tiku iesaistīts fiziskā vardarbībā savās mājās, kurā bija iesaistīts arī kāds pieaugušais” neḷauj piln̄̄gi precīzi noteikt šīs iesaistes veidu, respektīvi, vai vardarbība bijusi vērsta pret pašu pusaudzi, vai arī, piemēram, pusaudzis bijis fiziskas vardarbības liecinieks. Atbilde drīzāk iezīmē faktu, ka pusaudzis nāk no ǵimenes vides, kurā fiziska vardarbība notiek, kas arī var saistīties ar risku pašnāvnieciskai uzvedībai. Pret pusaudzi īstenota fiziska vardarbība iezīmējas kā pašnāvnieciskas uzvedības riska faktors arī citos pētījumos (Waldrop et al., 2007; Guo et al., 2018), taču sakarība ar fiziskās vardarbības liecinieka statusu vairākos pētījumos nav apstiprinājusies (Turner et al., 2012; Isohookana et al., 2013), kas liecina, ka precīzāka fiziskās vardarbības gadījuma definēšana ḷautu veikt precīzāku salīdzinājumu un izvairīties no interpretācijām.

Promocijas darbā kopumā abos dzimumos apstiprinājusies saistība arī starp pētītajiem pusaudžu pašnāvnieciskās uzvedības veidiem un seksuālu uzmākšanos, kurā bijis iesaistīts kāds pieaugušais gimenes loceklis. Saistībā ar seksuālu uzmākšanos gan iezīmējas nedaudz atšķirīga situācija, nekā ar citiem pētītajiem ar ǵimenes vidi saistītajiem faktoriem, proti, vadoties pēc nesamēroto izredžu aprēķina, zēniem seksuāla uzmākšanā ǵimenē saistīta ar 10,7 reizes lielākām izredzēm domām par pašnāvību un 16 reizes lielākām izredzēm pašnāvības mēǵinājumam (augstākās izredzes pašnāvības mēǵinājumam starp pētītajiem ar gímenes vidi saistītajiem faktoriem), meitenēm šīs izredzes ir attiecīgi 3,2 un 3,7. Pēc samērošanas ar respondentu vecumu un gimenes materiālo stāvokli izredžu attiecības izmainās minimāli, taču pēc samērošanas ar citiem ar ğimenes vidi saistītajiem faktoriem, lai arī abos dzimumos izredzes pašnāvnieciskajai uzvedībai seksuālas uzmākšanās gadījumā ir augstākas, statistiski nozīmīgi augstākas tās ir tikai attiecībā uz pašnāvības mēǵinājumiem zēniem. Šis fakts varētu būt skaidrojams ar diviem apstākḷiem. Pirmkārt, anketā uzdotais jautājums neḷauj spriest par šīs uzmākšanās gadījumu interpretāciju pusaudžu vidū, uzmākšanās biežumu, kā arī to vai tā ir rezultējusies ar, piemēram, vēl smagāku seksuālās vardarbības veidu - dzimumaktu, kas ierobežo iespēju spriest par saistību augsta pašnāvnieciskās uzvedības riska grupās. Otrkārt, seksuālu uzmākšanos aptaujas anketās ir atzīmējuši tikai 3,2\% (n = 111) zēnu un 1,2\% (n = 46) meiteņu, kas būtiski ierobežo statistisko jaudu sakarības noskaidrošanai, samērojot ar 
citiem pētìtajiem ar ǵimenes vidi saistītajiem faktoriem. N̦emot vērā izteikti augstās izredzes pašnāvnieciskajai uzvedībai seksuālās uzmākšanās gadījumā vienfaktora analīzē un pēc samērošanas ar respondenta vecumu un ǵimenes materiālo stāvokli, augstākas, bet ne statistiski nozīmīgi augstākas izredzes pēc samērošanas ar citiem pētītajiem ar ǵimenes vidi saistītajiem faktoriem, kā arī vairākos pētījumos atklāto saistību starp seksuālu vardarbību un pašnāvniecisko uzvedību (Waldrop et al., 2017; Martin et al., 2004; Ishookana et al., 2013; Guo et al., 2018), pirms pētījumu veikšanas ar lielāku mērḳa grupas izlasi nav iespējams izdarīt viennozīmīgu secinājumu, ka grupās, kur saistība nebija statistiski nozīmīga, seksuālas uzmākšanās gadījumā nepastāv augstāks risks pašnāvnieciskajai uzvedībai. Attiecīgi būtu rekomendējams nākotnē veikt padzilinātu šīs sakarības izpēti, izmantojot lielāku sasniegto respondentu atlasi, kā arī izmantot precīzākas fiziskās un seksuālās vardarbības definīcijas detalizētākai sakarību izpētei, tajā pat laikā ievērojot pētījumu ētikas apsvērumus un nodrošinot psihologisko atbalstu, lai neradītu bērnam emocionālas ciešanas, atsaucot atmiņā vai apjaušot seksuālās vardarbības epizodes.

\subsection{Pašnāvnieciskā uzvedība un ar vienaudžu vidi saistītie faktori}

Vērtējot promocijas darba ietvaros iegūtos rezultātus attiecībā uz pusaudžu pašnāvnieciskās uzvedības saistību ar vienaudžu emocionālā atbalsta trūkumu, jāsecina, ka meitenēm, kuras vienaudžu emocionālo atbalstu saṇem reti/nekad vai tikai dažreiz, vērojamas augstākas izredzes domām par pašnāvību gan pirms, gan pēc samērošanas ar citiem pētītajiem faktoriem, taču zēniem saistība ir statistiski nozīmīga tikai reti/nekad saņemta vienaudžu emocionālā atbalsta gadījumā un zaudē statistisko nozīmību pēc samērošanas ar citiem pētītajiem ar vienaudžu vidi saistītajiem faktoriem. Tāpat zēnu vidū ne pirms, ne pēc samērošanas ar citiem faktoriem netika novērota statistiski nozīmīga saistība starp pašnāvības mēǵinājumu un vienaudžu emocionālā atbalsta trūkumu, kamēr meitenēm, kuras vienaudžu emocionālo atbalstu saņem reti/nekad š̄̃ saistība apstiprinājās. Iegūtie rezultāti vedina domāt, ka analizētajā pusaudžu vecuma grupā vienaudžu emocionālā atbalsta trūkums izteiktākas negatīvas psihoemocionālās konsekvences rada tieši meitenēm. Tāpat salīdzinājumam jāuzsver fakts, pašnāvnieciskās uzvedības sakarības ar emocionālā atbalsta trūkumu gimenē bija izteiktākas un noturīgākas (sk. 4.2. nod.), kas savukārt vedina domāt, ka, neraugoties uz faktu, ka ar gimenes un vienaudžu vidi saistītie faktori tika analizēti atsevišķos regresijas modeḷos, emocionālā atbalsta trūkums no gimenes, iespējams, rada būtiskākas negatīvas psihoemocionālas konsekvences nekā emocionālā atbalsta trūkums no vienaudžiem. Šis secinājums ir zināmā pretrunā ar Korejā veiktā pētījumā atklāto, ka sliktām attiecībām ar 
vienaudžiem ir būtiskāka ietekme nekā zemai pusaudža piesaistei ǵimenei (Lee, 2016). Vērtējot kopumā iegūtie rezultāti attiecībā uz saistību starp pašnāvniecisko uzvedību un vienaudžu emocionālā atbalsta trūkumu ir šḳietamā pretrunā arī ar ASV veiktu pētījumu, kur neapstiprinājās pētītās sakarības starp problēmām attiecībās ar vienaudžiem un pašnāvniecisku uzvedību (De Luca, Wyman and Warren, 2012).

Abās dzimumu grupās gan pusaudžu domu par pašnāvību, gan pašnāvības mēginājuma izredzes palielina pašnāvnieciska pieredze vienaudžu vidū, jeb pusaudža atzīmētais fakts, ka kāds no pusaudža draugiem vai paziṇām ir izdarījis pašnāvību un/vai pašnāvības mēgininājumu. Turklāt š̄ faktora efekts uz pašnāvnieciskās uzvedības izredzēm ir būtiskākais starp pētītajiem ar vienaudžu vidi saistītajiem faktoriem gan pirms, gan pēc samērošanas - piemēram, zēniem pašnāvnieciska pieredze vienaudžu vidū izredzes domām par pašnāvību palielina 7,8 reizes pirms un 7,7 reizes pēc samērošanas ar vecumu, ǵimenes materiālo stāvokli un citiem pētītajiem ar vienaudžu vidi saistītajiem faktoriem. Cita starpā jāatzīmē, ka pašnāvniecisku pieredzi vienaudžu vidū atzīmē ievērojams īpatsvars pusaudžu 16,5\% zēnu un 27,7\% meiteņu, kas papildus iezīmē ievērojamo problēmas apjomu pusaudžu vidū. Arī šajā gadījumā viens no saistības skaidrojumiem varētu būt balstîts Sociālās mācīšanās teorijā (angl. - Social Learning Theory), kurā uzsvērts, ka jauni uzvedības veidi tiek iegūti (apgūti) caur tiešu pieredzi vai novērojot citu rīcību (Bandura, 1971). Tāpat, iespējams, pusaudži var būt tendēti iesaistīties dažādās pusaudžu grupās, kur pašnāvnieciskās uzvedības risks var būt augstāks (Briggs, Slater and Bowley, 2017). Nenoliedzami zaudējums (pabeigtas pašnāvības gadījumā) var radīt emocionālas ciešanas un ilgstošu nespēju samierināties ar notikušo, kas attiecīgi var saistīties ar paša pusaudža pašnāvniecisku uzvedību. Līdzīgi rezultāti par pašnāvnieciskas pieredzes vienaudžu vidū saistību ar pusaudža pašnāvniecisku uzvedību iegūti arī citos pētījumos (Bearman and Moody, 2004; Ho et al., 2000; Nanayakkara et al., 2013). Vienīgais ierobežojums saistībā ar jautājumiem pašnāvnieciskās pieredzes vienaudžu vidū noteikšanai varētu būt apstāklī, ka jautājums ir uzdots par "draugiem un paziņām”, kas teorētiski var arī nebūt pusaudža vienaudži, taču nav zināms cik šāda jautājuma interpretācija pusaudžu vidū varētu būt izplatîta un cik lielā mērā šis apstāklis varētu ietekmēt rezultātus. Neskatoties uz iepriekš minēto faktu, pusaudži ar pašnāvniecisku pieredzi vienaudžu vidū, tāpat kā pusaudži ar pašnāvniecisku pieredzi ǵimenē ir nozīmīga riska grupa pašnāvnieciskai uzvedībai ar attiecīgi augstāku risku arī pabeigtai pašnāvībai, kas jāṇem vērā profilakses programmās, kā arī veidojot skrīninga "instrumentus”, kas diferencē pusaudžus paaugstināta riska grupās tālākai intervencei.

Promocijas darbā iegūtie rezultāti liecina, ka gan domu par pašnāvību, gan pašnāvības mēgeinājuma izredzes abās dzimumu grupās palielina vienaudžu ņirgāšanās skolā un šī saistība 
saglabājas statistiski nozīmīga un izteikta arī pēc samērošanas ar respondenta vecumu, ǵimenes materiālo stāvokli un citiem pētītajiem ar vienaudžu vidi saistîtajiem faktoriem. Faktora būtisko ietekmi iezīmē arī fakts, ka arī tiem skolēniem, kuri vienaudžu ņirgāšanos skolā piedzīvojuši dažreiz, pēc samērošanas atkarībā no dzimuma vērojamas 1,5-1,6 reizes lielākas izredzes domām par pašnāvību un 1,7 reizes lielākas izredzes pašnāvības mēǵinājumam, salīdzinot ar respondentiem, kuri to nav piedzīvojuši. Šeit gan jāuzsver fakts, ka promocijas darbā izmantotais jautājums ṇirgāšanās noteikšanai atspoguḷo tikai verbālas ņirgāšanās faktu un šīs ņirgāšanās biežumu, bet nav iespējams noteikt vai pusaudzis ir bijis pakḷauts arī citiem ņirgāšanās konceptā ietvertajiem vardarbības veidiem (piemēram, fiziska aizskaršana, izslēgšana no vienaudžu grupas, ņirgāšanās interneta vidē), kā ar̄̄ vai verbālā ņirgāšanās īstenota spēka nevienlīdzības apstākḷlos starp upuri un pāridarītāju/-iem, kas, iespējams, palielinātu šī faktora efektu uz pašnāvniecisko uzvedību (Olweus, 1994), tomēr ņemot vērā, ka nereti upuris vienlaikus var būt pakḷauts vairākiem ņirgāšanās veidiem (Wang et al., 2010, l,oti iespējams, ka daḷa no upuriem, kas piedzīvo verbālu ņirgāšanos, piedzīvo arī citus ņirgāšanās veidus. Interesanti, ka pretēji promocijas darbā iegūtajiem rezultātiem, dažos citās valstīs veiktos pētījumos sakarība starp verbālu ņirgāšanos un pašnāvniecisku uzvedību neapstiprinājās (Brunstein Klomek et al., 2019; Bazilay et al., 2017), taču vairāku citu pētījumu rezultāti apstiprina ar̄̄ Latvijas pusaudžu vidū novēroto saistību starp verbālu ņirgāšanos un pašnāvniecisku uzvedību (Ford et al., 2017; Alavi et al., 2017). Promocijas darbā iegūtie rezultāti attiecībā uz saistību starp ņirgāšanās upura statusu un pašnāvniecisku uzvedību kopā ar augsto ņirgāšanās izplatību Latvijas skolēnu vidū (WHO, 2016) aktualizē nepieciešamību pēc starpsektoru sadarbībā balstîtas ņirgāšanās profilakses programmas Latvijas skolās, kura, vienlaikus ar psihoemocionālās labklājības veicināšanu skolēnu vidū kopumā, sniegtu ieguldījumu arī pašnāvnieciskās uzvedības un attiecīgi arī pašnāvību profilaksē.

\subsection{Pašnāvnieciskā uzvedība un individuālie faktori}

Promocijas darbā iegūtie rezultāti liecina, ka gan augsts, gan vidēji augsts depresijas simptomu līmenis palielina abu pētīto pašnāvnieciskās uzvedības veidu izredzes abās dzimumu grupās gan pirms, gan pēc samērošanas ar pusaudža vecumu, ǵimenes materiālo stāvokli un citiem pētītajiem individuālajiem faktoriem. Meitenēm pēc samērošanas augsta depresijas simptomu līmeņa gadījumā novērotas salīdzinoši augstākās izredzes pašnāvnieciskajai uzvedībai starp visiem pētîtajiem individuālajiem faktoriem, bet zēniem otrās augstākās. Depresijas saikne ar pabeigtām pašnāvībām un pašnāvniecisku uzvedību ir 
apstiprinājusies gan pieaugušo, gan pusaudžu populācijās veiktos pētījumos (Gustafsson and Jacobsson, 2000; Lesage et al., 1994; Hirokawa et al., 2012; Nock et al., 2013; Zubrick et al., 2017), taču mazāk ir pētījumu, kuros tiek analizēta saikne ar paaugstinātu depresijas simptomu līmeni, jo īpaši pusaudžu vidū, jo īpaši Latvijā. Šīs sakarības izpētes nozīme slēpjas faktā, ka pusaudžu skaits ar depresijas simptomiem, kuri nesasniedz klīniski nozīmīgas depresijas diagnostiskos kritērijus, ir augsts (Cuijpers et al., 2006) un, kā liecina promocijas darbā iegūtie rezultāti, arī šie pusaudži ir pašnāvnieciskās uzved̄̄bas riska grupa, pie tam 1,72,0 reizes augstākas izredzes pašnāvnieciskajai uzvedībai tika novērotas arī vidēji augsta depresijas simptomu līmeņa gadījumā. Promocijas darbā izmantotā CES-D skala tiek rekomendēta dažāda depresijas simptomu līmeņa noteikšanai arī pusaudžu populācijā (Stockings et al., 2015), taču šajā gadījumā kā viens no ierobežojumiem ir jāmin fakts, ka depresijas simptomu līmeņa noskaidrošanai uzdotie jautājumi tiek uzdoti par pēdējo septiṇu dienu periodu, bet pašnāvnieciskās uzvedības noskaidrošanai uzdotie jautājumi raksturo pašnāvnieciskās uzvedības mūža prevalenci. Neskatoties uz šo ierobežojumu - novērotā depresijas simptomu līmeņa saistība ar pašnāvniecisku uzvedību ir nozīmīga. L,oti iespējams faktori, kas izraisa depresijas simptomus, iedarbojas uz pusaudzi ilgstošā laika periodā, tāpat ilgstošs var būt arī paaugstināts depresijas simptomu līmenis. Neskatoties uz iepriekš minēto - promocijas darbā iegūtie rezultāti liecina, ka depresijas simptomu līmeņa noteikšana Latvijas 14-17 gadus veco pusaudžu vidū pašnāvnieciskās uzvedības riska identificēšanai ir nozīmīga un rekomendējama.

Promocijas darbā iegūtie rezultāti liecina, ka arī zems un vidēji zems pašcieṇas līmenis palielina abu pētīto pašnāvnieciskās uzvedības veidu izredzes abās dzimumu grupās gan pirms, gan pēc samērošanas ar pusaudža vecumu, ǵimenes materiālo stāvokli un citiem pētītajiem individuālajiem faktoriem, turklāt zema pašcieņas līmeņa gadījumā salīdzinoši augstākās izredzes pašnāvnieciskajai uzvedībai starp visiem pētītajiem individuālajiem faktoriem novērojamas zēniem, bet otrās augstākās - meitenēm. Kā jau uzsvērts 1.5.2. nodaḷā, pašcieņa nosaka indivīda pārliecību par savu piemērotību dzīvei un dzīves izvirzītajām prasībām, ir pārliecība spējā domāt, pārvarēt dzīves izaicinājumus, pārliecība par tiesībām būt laimīgam, sajūta, ka esi novērtēts, uzmanības cien̄̄gs, ar tiesībām aizstāvēt savas vajadzības un vēlmes, kā arī baudīt savu centienu augḷus. Pašcieṇa ir cilvēka normālas un veselīgas attīstības neatņemama sastāvdaḷa (Branden, 1990). Arī pēc samērošanas ar depresijas simptomu līmeni un citiem individuālajiem faktoriem Latvijas pusaudžu vidū sagalabājas statistiski nozīmīga saistība ne tikai starp pašnāvniecisko uzvedību un zemu pašcieņas līmeni, bet arī starp pašnāvniecisko uzvedību un vidēji zemu pašcieņas līmeni - dažos citos ārvalstīs veiktos pētījumos pēc samērošanas ar depresiju statistiski nozīmīga saistība saglabājās tikai ar 
atsevišķiem kopējo pusaudža pašcieņu veidojošajiem elementiem vai atsevišķā dzimumu grupā (Wang et al., 2003; Wild, Flisher and Lombard, 2004), taču kopumā atklātā saistība ir saskan̄ā ar citos, ārvalstīs veiktos pētījumos atklāto (Overholser et al., 1995; Lakey et al., 2014; O'Connor, Rasmussen and Hawton, 2009; Bridge, Goldstein and Brent, 2006; Tatnell et al., 2014). Promocijas darbā iegūtie rezultāti attiecībā uz pašcieņas līmeṇa un pašnāvnieciskās uzvedības saistību liecina, ka pašnāvības profilakses programmās būtiska loma ir arī intervencēm, kuras vērstas uz pusaudža pašcieņas līmeņa vairošanu (celšanu). Šādu intervenču izstrādāšana, aprobēšana un īstenošana varētu būt kompleksa un daudzu speciālistu sadarbībā balstīta, tomēr ir skaidrs, ka tā vairotu pusaudžu psihoemocionālo labklājību, spēju pārvarēt psihoemocionālos izaicinājumus un mazināt pašnāvniecisko uzvedību, kalpojot arī par nozīmīgu elementu arī pabeigtu pašnāvību profilaksei.

Vērtējot promocijas darba ietvaros iegūtos rezultātus attiecībā uz pusaudžu pašnāvnieciskās uzvedības saistību ar veselības pašvērtējumu jeb apmierinātību ar veselības stāvokli, jāsecina, ka meitenēm, kuras ar savu veselības stāvokli ir neapmierinātas vai ir vidēji apmierinātas, vērojamas augstākas izredzes domām par pašnāvību gan pirms, gan pēc samērošanas ar citiem pētītajiem individuālajiem faktoriem, taču zēniem pēc samērošanas ar citiem pētītajiem individuālajiem faktoriem saistība statistisko nozīmību zaudēja. Līdzīgi rezultāti attiecībā uz saistību ar domām par pašnāvību dzimumu grupās iegūti arī ASV veiktā pētījumā (Nkansah-Amankra, Walker, and Clark, 2009). Citā pētījumā minēts, ka meitenes savu veselību vērtē kā sliktāku arī pēc samērošanas ar dzīvesveidu raksturojošajiem un psiholoğiskajiem main̄̄gajiem (Vingilis, Wade and Seeley, 2002), kas vedina domāt, ka, iespējams, meitenes izteiktāk reageè uz savām veselības problēmām un vērtē tās kritiskāk nekā zēni. Tomēr Latvijas pusaudžu vidū abās dzimumu grupās apstiprinājās saistība starp neapmierinātību ar veselības stāvokli un pašnāvības mēǵinājumiem gan pirms, gan pēc samērošanas ar citiem pētītajiem individuālajiem faktoriem, kas liecina, ka attiecībā uz pašnāvības mēgeinājumiem riska grupā ir gan zēni, gan meitenes. Kopumā saistība starp sliktu veselības pašvērtējumu un pašnāvniecisku uzvedību apstiprinājusies arī Dienvidkorejā veiktā pētījumā (Kang et al., 2015), bet Peru veiktā pētījumā pēc samērošanas saistība vairs nav bijusi statistiski nozīmīga (Sharma et al., 2015).

Analizējot promocijas darba ietvaros iegūtos rezultātus attiecībā uz pusaudžu pašnāvnieciskās uzvedības saistību ar riskantu alkohola lietošanu jeb piedzeršanos dzīves laikā, jāsecina, ka meitenēm, kuras dzīves laikā piedzērušās 3 un vairāk reizes vai 1-2 reizes, vērojamas augstākas izredzes abiem pētītajiem pašnāvnieciskās uzvedības vediem gan pirms, gan pēc samērošanas ar citiem pētītajiem individuālajiem faktoriem, taču zēniem pēc samērošanas ar citiem pētītajiem individuālajiem faktoriem saistība starp pašnāvniecisko 
uzvedību un abām riskantas alkohola lietošanas kategorijām vairs nebija statistiski nozīmīga, turklāt zēniem saistība ar zemāko riskantas alkohola lietošanas kategoriju nebija statistiski nozīmīga jau vienfaktora analīzē. Pētîjumos noskaidrots, ka pusaudžiem ar atkarību izraisošo vielu lietošanas problēmām bieži vērojami ar negatīvo stresu saistīti notikumi dzīvē, problēmas starppersonu attiecībās, reducēts sociālais atbalsts, vientulība un bezpalīdzības sajūta (Pompili et al., 2012) kā arī depresija (Bond et al., 2005). N̦emot vērā, ka promocijas darbā veikta faktora samērošana arī ar depresijas simptomu līmeni un pašcieņas līmeni, iespējams, zēniem tieši šie divi faktori vairāk skaidro saistību, kas iezīmējas nesamērotajos izredžu attiecību rādītājos, bet meitenēm, iespējams, sakarību ietekmē citi “mehānismi". Literatūrā aprakstītas vairākas riskantas alkohola lietošanas motivācijas pusaudžiem hedoniskā motivācija, kad alkohols tiek lietots, lai radītu labu noskaņojumu, konformistiskā motivācija, kad alkohols tiek lietots, lai izvairītos no sociālā atraidījuma, socializācijas motivācija, kas raksturo alkohola lietošanu, lai iekḷautos grupā un problēmrisinošā motivācija, kas saistīta ar alkohola lietošanu, lai mazinātu nepatīkamas emocijas un izjūtas, un pašnāvnieciskā uzvedība visciešāk saistās tieši ar problēmrisinošo alkohola lietošanas motivāciju (Kokroḷeva u. c., 2008). Iespējams, atšķirības sakarībai ar pašnāvniecisko uzvedību dzimumu grupās saistītas ar atškirīībām riskantas alkohola lietošanas motivācijā dzimumu grupās, kas gan prasa padziḷinātu izpēti nākotnē. Kā priekšrocība riskantas alkohola lietošanas noteikšanai minama promocijas darba ietvaros izmantotā piedzeršanās definīcija, kas aprakstîta 2.2. nodaḷā un salīdzinoši precīzi ḷauj raksturot piedzeršanās faktu. Kopumā promocijas darba ietvaros iegūtie rezultāti par saistību ar pašnāvniecisko uzvedību saskan ar vairākumā ārvalstu pētījumu noskaidroto (Wu et al., 2004; Kokkevi et al., 2012; Peltzer and Pengpid, 2015; Wang and Yen, 2017), taču vairākumā šo pētījumu nav analizēta riskanta alkohola lietošana, bet gan alkohola lietošanas biežums.

Promocijas darbā iegūtie rezultāti liecina, ka pašnāvnieciskās uzvedības izredzes abās dzimumu grupās palielina arī ikdienas smēķēšana un saistība saglabājas statistiski nozīmīga arī pēc samērošanas ar vecumu, ǵimenes materiālo stāvokli un citiem pētītajiem individuālajiem faktoriem. Saistība starp pašnāvniecisku uzvedību un regulāru smēḳēšanu ir apstiprinājusies arī daudzos citos pētījumos gan pieaugušo, gan pusaudžu populācijās (Poorolajal and Darvishi, 2016; Wu et al., 2004; Kokkevi et al., 2012), taču zinātnieku vidū joprojām nav pilnīgas skaidrības par š̄is saistības cēloņiem - apjomīgas metaanalīzes diskusijas dạ̣ā norādīts, ka joprojām nav skaidrs vai smēḳēšana ietekmē pašnāvniecisku uzvedību caur biologiskiem mehānismiem, kas saistās ar pašu smēḳēšanu, vai arī šī saistība skaidrojama ar kolinearitāti starp smēķēšanu un citiem faktoriem, kas ir saistīti ar pašnāvniecisko uzvedību, piemēram, psihosociāliem riska faktoriem vai dažādu cita veida 
riska uzvedību. Tāpat minēts, ka smēḳēšana mēdz būt daḷa no problemātiskas uzvedības, kas ir saistīta ar dažādiem psihiskiem traucējumiem, narkotiku un alkohola lietošanu un seksuālu, un fizisku vardarbību, kas tiek uzskatīti par vieniem no nozīmīgākajiem pašnāvību un pašnāvnieciskas uzvedības cēloṇiem (Poorolajal and Darvishi, 2016). Šajā gadījumā gan kā promocijas darba priekšrocība minams fakts, ka ikdienas smēḳēšana logiistiskās regresijas modelī tika samērota gan ar depresijas simptomu līmeni, gan pašcieņas līmeni, gan riskantu alkohola lietošanu, gan narkotiku lietošanu un, lai arī pēc samērošanas izredzes pašnāvnieciskai uzvedībai samazinājās, saistība joprojām bija statistiski nozīmīga. Neskatoties uz cēloṇiem, promocijas darbā iegūtie rezultāti un citu valstu pētījumos noskaidrotais liecina, ka ikdienas smēḳēšana ir viens no faktoriem, kas diferencē pusaudžus ar augstāku pašnāvnieciskās uzvedības riskus, ko noteikti ir jāṇem vērā pašnāvnieciskās uzvedības un pašnāvību profilakses intervenču plānošanā un īstenošanā.

Iegūtie rezultāti liecina, ka pašnāvnieciskās uzved̄̄bas izredzes palielina arī narkotiku (marihuānas/hašiša, amfetamīna, LSD/citu halucinogēnu, kreka, kokaīna, heroīna, ekstaz̄̄ vai spice) lietošana dzīves laikā. Attiecībā uz domām par pašnāvību saistība ar narkotiku lietošanu gan pirms, gan pēc samērošanas ir statistiski nozīmīga abās dzimumu grupās, bet attiecībā uz pašnāvības mēg̣inājumu meitenēm pēc samērošanas ar citiem individuālajiem faktoriem šì saistība statistisko nozīmību zaudē. Arī šīs saistības skaidrojumi zinātniskajā literatūrā ir dažādi, piemēram, Taivānā veikta pētījuma par pusaudžu vielu lietošanas saistību ar pašnāvniecisku uzvedību dzimumu grupās diskusijas daḷā norādīts, ka akūta narkotiku intoksikācija var ietekmēt pusaudža spriestspēju un reducēt spēju kontrolēt impulsivitāti, savukārt hroniska - negatīvi ietekmēt smadzeņu attīstību un izmainīt uzvedību un procesus, kas regulē agresiju un impulsivitāti (Wang and Yen, 2017). Kopumā atklātā saistība starp narkotiku lietošanu un pašnāvniecisku uzvedību ir saskaņā ar citos pētījumos noskaidroto (Wang and Yen, 2017; Kokkevi et al., 2012; Wu et al., 2004), kas liecina, ka arī narkotiku lietošana ir viens no faktoriem, kas diferencē pusaudžus ar augstāku pašnāvnieciskās uzvedības riskus, ko ir jāṇem vērā pašnāvnieciskās uzvedības un pašnāvību profilakses intervenču plānošanā un īstenošanā.

\subsection{Citi apsvērumi}

Balstoties uz promocijas darbā iegūtajiem rezultātiem secināms, ka pirmā promocijas darba hipotēze, ka abās dzimumu grupās pastāv saistība starp pusaudžu pašu ziṇotajām domām par pašnāvību un visiem pētītajiem ar gímenes vidi saistītajiem, vienaudžu vidi raksturojošajiem un individuālajiem faktoriem ir apstiprinājusies daḷēji, jo zēniem pēc 
samērošanas ar citiem pētītajiem attiecīgās faktoru grupas faktoriem netika novērota statistiski nozīmīga saistība starp domām par pašnāvību un seksuālu uzmākšanos ǵimenē, vienaudžu emocionālā atbalsta trūkumu, pazeminātu veselības pašvērtējumu un riskantu alkohola lietošanu, savukārt meitenēm - nedzīvošanu ar abiem biologiskajiem vecākiem un seksuālu uzmākšanos ǵimenē. Taču iepriekš minētās saistības dzimumu grupās bija statistiski nozīmīgas vienfaktora analīzē un pēc samērošanas ar respondenta vecumu un ǵimenes materiālo stāvokli.

Arī otrā promocijas darba hipotēze, ka abās dzimumu grupās pastāv saistība starp pusaudžu pašu ziņotajiem pašnāvības mēǵinājumiem un visiem pētītajiem ar ǵimenes vidi saistītajiem, vienaudžu raksturojošajiem un individuālajiem faktoriem ir apstiprinājusies daḹji, jo zēniem pēc samērošanas ar citiem pētītajiem attiecīgās faktoru grupas faktoriem netika novērota statistiski nozīmīga saistība ar vienaudžu emocionālā atbalsta trūkumu un riskantu alkohola lietošanu, savukārt meitenēm - ar seksuālu uzmākšanos ǵimenē un narkotiku lietošanu. Taču iepriekš minētās saistības dzimumu grupās (izṇemot saistību ar vienaudžu emocionālā atbalsta trūkumu zēniem) bija statistiski nozīmīgas vienfaktora analīzēe un pēc samērošanas ar respondenta vecumu un gímenes materiālo stāvokli.

Papildus jāṇem vērā fakts, ka pêtījums ir veikts kā šḳērsgriezuma pētījums un šāds pētījuma dizains neḷauj izdarīt secinājumus par cēloṇu-seku sakarībām laikā. Tāpat pētījuma rezultātus var ietekmēt sistemātiskā atcerēšanās kḷūda, jo īpaši attiecībā uz mainīgajiem, kas aprēkināti pēc pusaudžu atbildēm par visas dzīves laiku, līdz ar to atcerēšanās novirze var ietekmēt saistības ciešumu starp pašnāvniecisku uzvedību un pētītajiem faktoriem.

N̦emot vērā dažādus apstākḷus, t. sk. skolēnu kavējumus un atteikumus piedalīties aptaujā, aprēkinātais nerespondences līmenis skolās un klasēs, kas piekrita piedalīties aptaujā bija 15,3\% no visiem skolēniem (Trapencieris u. c., 2012). N̦emot vērā, ka, iespējams, pašnāvnieciskās uzvedības un dažāda veida riska faktoru izplatība šajās pusaudžu grupās var atšķirties, pilnīgas informācijas iegūšanai nākotnē būtu nepieciešams veikt papildus pētījumus par pašnāvnieciskās uzvedības izplatību un asociētajiem riska faktoriem skolu kavējošo, kā arī skolu neapmeklējošo pusaudžu vidū.

Promocijas darba ietvaros veiktā analīze ir vien̄igā līdz šim veiktā šada veida un detalizācijas pakāpes attiecīgajai pusaudžu vecuma grupai reprezentatīva ar pusaudžu pašnāvniecisko uzvedību saistīto faktoru analīze Latvijā ar ne tikai teorētisku, bet arī būtisku praktisku ieguldījumu riska grupu diferencēšanai un sabiedrības veselības politikas veidošanai un intervenču īstenošanai pašnāvnieciskās uzvedības un pašnāvību profilaksei. 


\section{SECINĀJUMI}

1. Ievērojams īpatsvars - 15,7\% Latvijas 14-17 gadus veco pusaudžu pārdomājuši konkrētu veidu, vietu vai rīcību pašnāvības izdarīšanai - nedaudz vairāk kā katrs desmitais zēns $(11,7 \%)$ un gandrīz katra piektā meitene $(19,4 \%)$.

2. Ievērojams īpatsvars - 8,2\% Latvijas 14-17 gadus veco pusaudžu atzīmē dzīves laikā izdarītu pašnāvības mēginājumu - 5,9\% zēnu un 10,2\% meiteņu.

3. Abu pētîto pašnāvnieciskās uzvedības veidu izplatība ir augstāka meiteṇu vidū.

4. Domu par pašnāvību izplatība ir augstāka to pusaudžu vidū, kuri savas gimenes materiālo stāvokli salīdzinājumā ar citām ğimenēm Latvijā vērtē kā sliktāku, savukārt meiteņu vidū šādi vērtēta ǵimenes materiālā stāvokḷa gadījumā vērojama arī augstāka pašnāvības mēǵinājumu izplatība.

5. Ar ǵimenes vidi saistītie faktori, kas neatkarīgi paaugstina izredzes domām par pašnāvību abās dzimumu grupās ir pašnāvnieciska pieredze gimenē, fiziska vardarb̄̄ba gimenē, reti/nekad un dažreiz izjusts vecāku emocionālais atbalsts, bet atsevišķki zēniem nedzīvošana ar abiem biologiskajiem vecākiem.

6. Ar gimenes vidi saistītie faktori, kas neatkarīgi paaugstina izredzes pašnāvības mēǵinājumam abās dzimumu grupās ir pašnāvnieciska pieredze ǵimenē, fiziska vardarbība ǵimenē, reti/nekad izjusts vecāku emocionālais atbalsts un nedzīvošana ar abiem bioloǵiskajiem vecākiem, bet atsevišķi zēniem - seksuāla uzmākšanās ǵimenē un atsevišķi meitenēm - dažreiz izjusts vecāku emocionālais atbalsts.

7. Ar vienaudžu vidi saistītie faktori, kas neatkarīgi paaugstina izredzes domām par pašnāvību abās dzimumu grupās ir pašnāvnieciska pieredze vienaudžu vidū, vienmēr/bieži un dažreiz piedzīvota ņirgāšanās skolā, bet atsevišḳi meitenēm - reti/nekad un dažreiz izjusts vienaudžu emocionālais atbalsts.

8. Ar vienaudžu vidi saistītie faktori, kas neatkarīgi paaugstina izredzes pašnāvības mēǵinājumam abās dzimumu grupās ir pašnāvnieciska pieredze vienaudžu vidū, vienmēr/bieži un dažreiz piedzīvota ņirgāšanās skolā, bet atsevišķi meitenēm - reti/nekad izjusts vienaudžu emocionālais atbalsts.

9. Individuālie faktori, kas neatkarīgi paaugstina izredzes domām par pašnāvību abās dzimumu grupās ir augsts un vidēji augsts depresijas simptomu līmenis, zems un vidēji zems pašcieņas līmenis, narkotiku lietošana dzīves laikā un ikdienas smēkēšana, bet atsevišḳi meitenēm - neapmierinātība un vidēja apmierinātība ar savu veselības stāvokli, kā arī riskanta alkohola lietošana dzīves laikā. 
10. Individuālie faktori, kas neatkarīgi paaugstina izredzes pašnāvības mēǵinājumam abās dzimumu grupās ir augsts un vidēji augsts depresijas simptomu līmenis, zems un vidēji zems pašcieņas līmenis, ikdienas smēķēšana un neapmierinātība ar savu veselības stāvokli, atsevišḳi meitenēm - riskanta alkohola lietošana dz̄ives laikā, bet atsevišķi zēniem - narkotiku lietošana dzīves laikā. 


\section{PRAKTISKĀS REKOMENDĀCIJAS}

1. Promocijas darba secinājumi liecina, ka pastāv nozīmīga saikne starp pusaudžu pašnāvniecisko uzvedību un gan ar ǵimenes vidi saistītajiem, gan vienaudžu vidi raksturojošajiem, gan individuālajiem faktoriem un šīs ietekmējošo faktoru grupas, un atsevišḳus faktorus jāṇem vērā gan speciālistiem, kuri strādā ar pusaudžiem ikdienā (ǵimenes ārsti, psihologi, psihoterapeiti, psihiatri, pedagogi, sociālie pedagogi u. c.) potenciāla riska identificēšanai, gan sabiedrības veselības, labklājības un citu iesaistīto sektoru politikas veidotājiem intervenču plānošanai sekmīgai pašnāvnieciskās uzvedības un pašnāvību profilaksei, uzmanību veltot gan psihologiski atbalstošas un no vardarbības brīvas gimenes un vienaudžu vides veidošanai, gan pusaudžu pašcieņas vairošanai, depresijas mazināšanai un profilaksei, vispārējās veselības veicināšanai un atkarību izraisošo vielu lietošanas profilaksei.

2. Latvijā, līdzīgi kā citās ES valstīs, nepieciešams izstrādāt un apstiprināt atsevišķas, specifiskas sabiedrības psihiskās veselības veicināšanas un pašnāvību profilakses pamatnostādnes ar konkrētām aktivitātēm pusaudžu pašnāvnieciskās uzvedības un pašnāvību profilaksei. Problēmas aktualitāte augsto pašnāvību rādītāju kontekstā Latvijā Sabiedrības veselības veselības pamatnostādnēs ir uzsvērta jau šobrīd un promocijas darba secinājumi sniedz uz pierādījumiem balstītu informāciju starpsektoru (veselības, labklājības, izglītības u. c.) sadarbībā balstītu profilakses intervenču īstenošanai pusaudžu populācijā kopumā un riska grupās.

3. Balstoties uz promocijas darbā iegūtajiem rezultātiem valsts līmeņa ekspertu grupās iespējams lemt par pašnāvnieciskās uzvedības izplatības noteikšanai izmantoto jautājumu kā indikatoru nepārtrauktu iekḷaušanu periodiskajos reprezentatīvajos pusaudžu populācijas apsekojumos, lai varētu sekot situācijas izmaiṇām dinamikā un atbilstoši reageèt.

4. Nepieciešams turpināt izpēti, īpašu uzmanību pievēršot detalizētai, padziḷinātai un papildus saistību izpētei starp pašnāvniecisko uzvedību un dažāda veida gimenē un vienaudžu vidū īstenotu vardarbību (fizisku, seksuālu, emocionālu, fizisku atstāšanu novārtā, emocionālu atstāšanu novārtā, ņirgāšanos, izslēdzot no vienaudžu grupas, ņirgāšanos interneta vidē u. c.) pēc iespējas lielās respondentu atlases kopās ar atbilstošu statistisko jaudu precīzai saistību noskaidrošanai ar faktoriem, kuru izplatība ir salīdzinoši zema (jo īpaši, seksuālu vardarbību).

5. Tāpat būtisku papildus ieguldījumu sniegtu pašnāvnieciskās uzvedības izpēte starp pusaudžiem ar dažāda veida riskantas alkohola lietošanas motivāciju, starp ikdienas 
smēḳēšanu un pašnāvniecisko uzvedību atklātās saistības cēloṇu izpēte, sakarību izpēte ar elektronisko smēķēěanas ierīču lietošanu un procesu atkarībām, kā arī pašnāvnieciskās uzvedības izplatības un ar to saistīto faktoru analīze skolu kavējošo pusaudžu vidū. 


\section{IZMANTOTĀ LITERATŪRA}

1. Ahmedani, B. K., Peterson, E. L., Hu, Y., Rossom, R. C., Lynch, F., Lu, C. Y., Waitzfelder, B. E., Owen-Smith, A. A., Hubley, S., Prabhakar, D., Williams, L. K., Zeld, N., Mutter, E., Beck, A., Tolsma, D., Simon, G. E. 2017. Major Physical Health Conditions and Risk of Suicide. American journal of preventive medicine. 53(3), 308-315.

2. Alavi, N., Reshetukha, T., Prost, E., Antoniak, K., Patel, C., Sajid, S., Groll, D. 2017. Relationship between Bullying and Suicidal Behaviour in Youth presenting to the Emergency Department. Journal of the Canadian Academy of Child and Adolescent Psychiatry. 26(2), 70-77.

3. Allison, S., Roeger, L., Martin, G., Keeves, J. 2001. Gender differences in the relationship between depression and suicidal ideation in young adolescents. The Australian and New Zealand journal of psychiatry. 35(4), 498-503.

4. Bali, R., Feng, H. 2003. Changes in Family Structure and Child Outcomes: Roles of Economic and Familial Resources. Policy Studies Journal. 31(3), 309-330.

5. Baltāne, Z., Liepiņa, E., Mauriņa, A., Meḷķe-Prižovaite L., Misiņš, J., N̦esterovoča, D., Paševska, M., Pavlovska, Z., Pildava, S., Ramuse, E., Šneidere, L., Štāle, M., Zariņa B., Zelmene, S., Zīle, I. 2017. Latvijas veselības aprūpes statistikas gadagrāmata: 18. izdevums. Rīga: Slimību profilakses un kontroles centrs.

6. Bandura, A. 1971. Social Learning Theory. New York (NY): General Learning Corporation.

7. Barzilay, S., Brunstein Klomek, A., Apter, A., Carli, V., Wasserman, C., Hadlaczky, G., Hoven, C. W., Sarchiapone, M., Balazs, J., Kereszteny, A., Brunner, R., Kaess, M., Bobes, J., Saiz, P., Cosman, D., Haring, C., Banzer, R., Corcoran, P., Kahn, J. P., Postuvan, V., Podlogar, T., Sisask, M., Varnik, A., Wasserman, D. 2017. Bullying Victimization and Suicide Ideation and Behavior Among Adolescents in Europe: A 10-Country Study. The Journal of adolescent health. 61(2), 179-186.

8. Bearman, P. S., Moody, J. 2004. Suicide and friendships among American adolescents. American Journal Of Public Health. 94(1), 89-95.

9. Beautrais, A. L. 2002. Gender issues in youth suicidal behaviour. Emergency medicine (Fremantle, W.A.). 14(1), 35-42.

10. Bernburg, J. G., Thorlindsson, T., Sigfusdottir, I. D. 2009. The spreading of suicidal behavior: The contextual effect of community household poverty on adolescent suicidal behavior and the mediating role of suicide suggestion. Social science \& medicine. 68(2), 380-389.

11. Bhatia, S. K., Bhatia, S. C. 2007. Childhood and adolescent depression. American Family Physician. 75(1), 73-80.

12. Bolton, J. M., Walld, R., Chateau, D., Finlayson, G., Sareen, J. 2015. Risk of suicide and suicide attempts associated with physical disorders: a population-based, balancing score-matched analysis. Psychological medicine. 45(3), 495-504.

13. Bond, L., Toumbourou, J. W., Thomas, L., Catalano, R. F., Patton, G. 2005. Individual, family, school, and community risk and protective factors for depressive symptoms in adolescents: a comparison of risk profiles for substance use and depressive symptoms. Prevention science. 6(2), 73-88.

14. Borges, G., Benjet, C., Medina-Mora, M. E., Orozco, R., Molnar, B. E., Nock, M. K. 2008. Traumatic events and suicide-related outcomes among Mexico City adolescents. Journal of child psychology and psychiatry, and allied disciplines. 49(6), 654-666.

15. Borowsky, I. W., Ireland, M., Resnick, M. D. 2001. Adolescent suicide attempts: risks and protectors. Pediatrics. 107(3), 485-493.

16. Branden, N. 1990. What Is Self-Esteem? In: International Conference on Self-Esteem. Asker/Oslo: International Conference on Self-Esteem. Available from: https://eric.ed.gov/?id=ED325783 [accessed on 11.09.2018].

17. Brent, D. A., Mann, J. J. 2006. Familial pathways to suicidal behavior--understanding and preventing suicide among adolescents. The New England journal of medicine. 355(26), 27192721.

18. Bridge, J. A., Goldstein, T. R., Brent, D. A. 2006. Adolescent suicide and suicidal behavior. Journal of child psychology and psychiatry, and allied disciplines. 47:3/4, 372-394.

19. Briggs, S., Slater, T., Bowley, J. 2017. Practitioners' experiences of adolescent suicidal behaviour in peer groups. Journal of psychiatric and mental health nursing. 24(5), 293-301. 
20. Brooks, F. M., Magnusson, J., Spencer, N., Morgan, A. 2012. Adolescent multiple risk behaviour: an asset approach to the role of family, school and community. Journal of public health (Oxford, England). 34, i48-56. Available from: doi: 10.1093/pubmed/fds001 [accessed on 01.08.2018].

21. Brown, J., Cohen, P., Johnson, J. G., Smailes, E. M. 1999. Childhood abuse and neglect: specificity of effects on adolescent and young adult depression and suicidality. Journal of the American Academy of Child and Adolescent Psychiatry. 38(12), 1490-1496.

22. Bruffaerts, R., Demyttenaere, K., Borges, G., Haro, J. M., Chiu, W. T., Hwang, I., Karam, E. G., Kessler, R. C., Sampson, N., Alonso, J., Andrade, L. H., Angermeyer, M., Benjet, C., Bromet, E., de Girolamo, G., de Graaf, R., Florescu, S., Gureje, O., Horiguchi, I., Hu, C., Kovess, V., Levinson, D., Posada-Villa, J., Sagar, R., Scott, K., Tsang, A., Vassilev, S. M., Williams, D. R., Nock, M. K. 2010. The British journal of psychiatry. 197(1), $20-27$.

23. Brunner, R., Kaess, M., Parzer, P., Fischer, G., Carli, V., Hoven, C. W., Wasserman, C., Sarchiapone, M., Resch, F., Apter, A., Balazs, J., Barzilay, S., Bobes, J., Corcoran, P., Cosmanm, D., Haring, C., Iosuec, M., Kahn, J. P., Keeley, H., Meszaros, G., Nemes, B., Podlogar, T., Postuvan, V., Saiz, P.A., Sisask, M., Tubiana, A., Varnik, A., Wasserman, D. 2014. Life-time prevalence and psychosocial correlates of adolescent direct self-injurious behavior: a comparative study of findings in 11 European countries. Journal of child psychology and psychiatry, and allied disciplines. 55(4), 337-348.

24. Brunstein Klomek, A., Barzilay, S., Apter A., Carli, V., Hoven, C. W., Sarchiapone, M., Hadlaczky, G., Balazs, J., Kereszteny, A., Brunner, R., Kaess, M., Bobes, J., Saiz, P. A., Cosman, D., Haring, C., Banzer, R., McMahon, E., Keeley, H., Kahn, J. P., Postuvan, V., Podlogar, T., Sisask, M., Varnik, A., Wasserman, D. 2019. Bi-directional longitudinal associations between different types of bullying victimization, suicide ideation/attempts, and depression among a large sample of European adolescents. Journal of child psychology and psychiatry, and allied disciplines. 60(2), 209-215.

25. Buhrmester, D. 1990. Intimacy of friendship, interpersonal competence, and adjustment during preadolescence and adolescence. Child development. 61(4), 1101-1111.

26. Calati, R., Laglaoui Bakhiyi, C., Artero, S., Ilgen, M., Courtet, P. 2015. The impact of physical pain on suicidal thoughts and behaviors: Meta-analyses. Journal of psychiatric research. 71, 1632. Available from: doi:10.1016/j.jpsychires.2015.09.004. [accessed on 20.08.2018].

27. Castle, K., Kreipe, R. 2007. Suicidal Behavior. In: Pediatric Clinical Advisor (second edition): Instant Diagnosis and Treatment. Philadelphia: Mosby, 544-545.

28. Cavanagh, J. T., Carson, A. J, Sharpe, M., Lawrie, S. M. 2003. Psychological autopsy studies of suicide: a systematic review. Psychological medicine. 33(3), 395-405.

29. Cerel, J., Roberts, T. A. 2005. Suicidal behavior in the family and adolescent risk behavior. The Journal of adolescent health. 36(4), 352.e9-16.

30. Cerel, J., Roberts, T. A., Nilsen, W. J. 2005. Peer suicidal behavior and adolescent risk behavior. The Journal of nervous and mental disease. 193(4), 237-243.

31. Chan, S., Denny, S., Fleming, T., Fortune, S., Peiris-John, R., Dyson, B. 2018. Exposure to suicide behaviour and individual risk of self-harm: Findings from a nationally representative New Zealand high school survey. The Australian and New Zealand journal of psychiatry. 52(4), 349356.

32. Chatard, A., Selimbegović, L., Konan, P. N. 2009. Self-esteem and suicide rates in 55 Nations. European Journal of Personality. 23(1), 19-32.

33. Colarossi, L. G., Eccles, J. S. 2003. Differential Effects of Support Providers on Adolescents' Mental Health. Social Work Research. 27(1), 19-30.

34. Conger, R. D., Conger, K. J., Elder, G. H. Jr., Lorenz, F. O., Simons, R. L., Whitbeck, L. B. 1992. A family process model of economic hardship and adjustment of early adolescent boys. Child Development. 63(3), 526-541.

35. Crosby, A. E., Ortega, L., Melanson, C. 2011. Self-directed Violence Surveillance: Uniform Definitions and Recommended Data Elements, Version 1.0. Atlanta (GA): Centers for Disease Control and Prevention, National Center for Injury Prevention and Control.

36. Cuijpers, P., van Straten, A., Smits, N., Smit, F. 2006. Screening and early psychological intervention for depression in schools: systematic review and meta-analysis. European child \& adolescent psychiatry. 15(5), 300-307.

37. De Leo, D., Burgis, S., Bertolote, J. M., Kerkhof, A. J., Bille-Brahe, U. 2006. Definitions of suicidal behavior: Lessons learned from the WHo/EURO multicentre Study. Crisis. 27(1), 4-15. 
38. De Luca, S. M., Wyman, P., Warren, K. 2012. Latina adolescent suicide ideations and attempts: associations with connectedness to parents, peers, and teachers. Suicide \& life-threatening behavior. 42(6), 672-683.

39. Dyregrov, A., Gjestad, R., Bie Wikander A. M., Vigerust, S. 1999. Reactions following the sudden death of a classmate. Scandinavian Journal of Psychology. 40(3), 167-176.

40. Donath, C., Graessel, E., Baier, D., Bleich, S., Hillemacher, T. 2014. Is parenting style a predictor of suicide attempts in a representative sample of adolescents? BMC pediatrics. 14:113. Available from: doi:10.1186/1471-2431-14-113 [accessed on 01.08.2018].

41. Enns, M. W., Cox, B. J., Afifi, T. O., De Graaf, R., Ten Have M, Sareen J. 2006. Childhood adversities and risk for suicidal ideation and attempts: a longitudinal population-based study. Psychological medicine. 36(12), 1769-1778.

42. Erkanli, A., Angold, A. 2006. Is there an epidemic of child or adolescent depression? Journal of child psychology and psychiatry, and allied disciplines. 47(12), 1263-1271.

43. Eskin, M., Palova, E., Krokavcova, M. 2014. Suicidal behavior and attitudes in Slovak and Turkish high school students: a cross-cultural investigation. Archives of suicide research. 18(1), $58-73$.

44. European Commision. 2008. European Pact for Mental Health and Well-Being. Brussels: EU high level conference "Together for Mental Health" Available from: http://ec.europa.eu/health/ph_determinants/life_style/mental/docs/pact_en.pdf [accessed on 09.07.2018]

45. Eurostat. 2018. Suicide death rate by age group. In: Eurostat. Available from: https://ec.europa.eu/eurostat/web/products-datasets//tps00202 [accessed on 28.06.2018]

46. Evans, E., Hawton, K., Rodham, K., Deeks, J. 2005. The prevalence of suicidal phenomena in adolescents: a systematic review of population-based studies. Suicide \& life-threatening behavior. 35(3), 239-250.

47. Fatima S., Sheikh, H. 2016. Adolescent Aggression as Predicted from Parent-Child Relationships and Executive Functions. The American journal of psychology. 129(3), 283-294.

48. Fedorowicz, V. J., Fombonne, E. 2007. Suicidal behaviours in a population-based sample of French youth. Canadian journal of psychiatry. 52(12), 772-779.

49. Feigelman, W., Gorman, B. S. 2008. Assessing the effects of peer suicide on youth suicide. Suicide \& life-threatening behavior. 38(2), 181-194.

50. Fergusson, D. M., Woodward, L. J., Horwood, L. J. 2000. Risk factors and life processes associated with the onset of suicidal behaviour during adolescence and early adulthood. Psychological medicine. 30(1), 23-39.

51. Field, A. 2013. Discovering statistics using IBM SPSS Statistics. 4th ed. Canada: SAGE Publications.

52. Fonseca-Pedrero, E., Inchausti, F., Pérez-Gutiérrez, L., Aritio Solana, R., Ortuño-Sierra, J., Sánchez-García, M. Á., Lucas-Molina, B., Domínguez, C., Foncea, D., Espinosa, V., Gorría, A., Urbiola-Merina, E., Fernández, M., Merina Díaz, C., Gutiérrez, C., Aures, M., Campos, M. S., Domínguez-Garrido, E., Pérez de Albéniz Iturriaga, A. 2018. Suicidal ideation in a communityderived sample of Spanish adolescents. Revista de psiquiatría y salud mental. 11(2), 76-85.

53. Ford, R., King, T., Priest, N., Kavanagh, A. 2017. Bullying and mental health and suicidal behaviour among 14- to 15-year-olds in a representative sample of Australian children. The Australian and New Zealand journal of psychiatry. 51(9), 897-908.

54. Gilbert, R., Widom, C. S., Browne, K., Fergusson, D., Webb, E., Janson, S. 2009. Burden and consequences of child maltreatment in high-income countries. Lancet. 373(9657), 68-81.

55. Goldsmith, S. K., Pellmar, T. C., Kleinman, A. M., Bunney, W. E. 2002. Reducing Suicide: A National Imperative. Washington (DC): National Academies Press.

56. Goodfellow, B., Kõlves, K., De Leo, D. 2018. Contemporary Nomenclatures of Suicidal Behaviors: A Systematic Literature Review. Suicide \& life-threatening behavior. 48(3), 353-366.

57. Goodwin, R.D., Mocarski, M., Marusic, A., Beautrais, A. 2013. Thoughts of self-harm and helpseeking behavior among youth in the community. Suicide and Life-Threatnening Behavior. 43(3), $305-312$.

58. Guo, L., Wang, W., Gao, X., Huang, G., Li, P., Lu, C. 2018. Associations of Childhood Maltreatment with Single and Multiple Suicide Attempts among Older Chinese Adolescents. The Journal of pediatrics. 196, 244-250. Available from: doi:10.1016/j.jpeds.2018.01.032 [accessed on 20.08.2018]. 
59. Gustafsson, L., Jacobsson, L. 2000. On mental disorder and somatic disease in suicide: A psychological autopsy study of 100 suicides in northern Sweden. Nordic Journal of Psychiatry. 54(6), 383-395.

60. Hadland, S. E., Wood, E., Dong, H., Marshall, B. D., Kerr, T., Montaner, J. S., DeBeck, K. 2015. Suicide Attempts and Childhood Maltreatment Among Street Youth: A Prospective Cohort Study. Pediatrics. 136(3), 440-449.

61. Halldörsson, M., Kunst, A. E., Köhler, L., Mackenbach, J. P. 2000. Socioeconomic inequalities in the health of children and adolescents. A comparative study of the five Nordic countries. European Journal of Public Health. 10(4), 281-288.

62. Hamdan, S., Levi, D., Dahan, L., Stukalin, E. 2018. The effect of sleep disturbances and internet addiction on suicidal ideation among adolescents in the presence of depressive symptoms. Psychiatry Research. 267, 327-332. Available from: 10.1016/j.psychres.2018.03.067. [accessed on 09.07.2018].

63. Hardt, J., Sidor, A., Nickel, R., Kappis, B., Petrak, P., Egle, U. T. 2008. Childhood Adversities and Suicide Attempts: A Retrospective Study. Journal of Family Violence. 23(8), 713-718.

64. Hawker, D. S., Boulton, M. J. 2000. Twenty years' research on peer victimization and psychosocial maladjustment: a meta-analytic review of cross-sectional studies. Journal of child psychology and psychiatry, and allied disciplines. 41(4), 441-455.

65. Hawton, K., Arensman, E., Wasserman, D., Hultén, A., Bille-Brahe, U., Bjerke, T., Crepet, P., Deisenhammer, E., Kerkhof, A., De Leo, D., Michel, K., Ostamo, A., Philippe, A., Querejeta, I., Salander-Renberg, E., Schmidtke, A., Temesváry, B. 1998. Relation between attempted suicide and suicide rates among young people in Europe. Journal of Epidemiology and Community Health. 52(3), 191-194.

66. Hawton, K., Bergen, H., Kapur, N., Cooper, J, Steeg, S., Ness, J., Waters, K. 2012. Repetition of self-harm and suicide following self-harm in children and adolescents: findings from the Multicentre Study of Self-harm in England. Journal of child psychology and psychiatry, and allied disciplines. 53(12), 1212-1219.

67. Hawton, K., Harris, L. 2008. How Often Does Deliberate Selfharm Occur relative to Each Suicide? A Study of Variations by Gender and Age. Suicide and Life-Threatnening Behavior. 38(6), 650-660.

68. Hibell, B., Guttormsson U., Ahlström, S., Balakireva, O., Bjarnason T., Kokkevi, A., Kraus, L. 2009. The 2007 ESPAD Report: Substance Use Among Students in 35 European Countries. Stockholm: The Swedish Council for Information on Alcohol and Other Drugs (CAN).

69. Hibell, B., Guttormsson, U., Ahlström, S., Balakireva, O., Bjarnason, T., Kokkevi, A., Kraus, L. 2012. The 2011 ESPAD Report: Substance Use Among Students in 36 European Countries. Stockholm: The Swedish Council for Information on Alcohol and Other Drugs (CAN).

70. Hinkle, D. E., Wiersma, W., Jurs, S. G. 2003. Applied Statistics for the Behavioral Sciences: $5^{\text {th }}$ ed. Boston: Houghton Mifflin.

71. Hirokawa, S., Kawakami, N., Matsumoto, T., Inagaki, A., Eguchi, N., Tsuchiya, M., Katsumata, Y., Akazawa, M., Kameyama, A., Tachimori, H., Takeshima, T. 2012. Mental disorders and suicide in Japan: a nation-wide psychological autopsy case-control study. Journal of affective disorders. 140(2), 168-175.

72. Ho, T. P., Leung, P. W., Hung, S. F., Lee, C. C., Tang, C. P. 2000. The mental health of the peers of suicide completers and attempters. Journal of child psychology and psychiatry, and allied disciplines. 41(3), 301-308.

73. Holt, M. K., Vivolo-Kantor, A. M., Polanin, J. R., Holland, K. M., DeGue, S., Matjasko, J. L., Wolfe, M., Reid, G. 2015. Bullying and suicidal ideation and behaviors: a meta-analysis. Pediatrics. 135(2), e496-509.

74. Hu, J., Dong, Y., Chen, X., Liu, Y., Ma, D., Liu, X., Zheng, R., Mao, X., Chen, T., He, W. 2015. Prevalence of suicide attempts among Chinese adolescents: A meta-analysis of cross-sectional studies. Comprehensive psychiatry. 61, 78-89. Available from: doi:10.1016/j.comppsych.2015.05.001 [accessed on 16.07.2018].

75. Idler, E. L., Benyamini, Y. 1997. Self-rated health and mortality: a review of 27 community studies. Journal of health and social behavior. 38(1), 21-37.

76. Ilgen, M. A., Kleinberg, F., Ignacio, R. V., Bohnert, A. S., Valenstein, M., McCarthy, J. F., Blow, F. C., Katz, I. R. 2013. Noncancer pain conditions and risk of suicide. JAMA psychiatry. 70(7), 692-697. 
77. Isohookana, R., Riala, K., Hakko, H., Räsänen, P. 2013. Adverse childhood experiences and suicidal behavior of adolescent psychiatric inpatients. European child \& adolescent psychiatry. 22(1), 13-22.

78. Yoder, K. A., Hoyt, D. R. 2005. Family economic pressure and adolescent suicidal ideation: application of the family stress model. Suicide \& life-threatening behavior. 35(3), 251-264.

79. Joe, S., Baser, R. S, Neighbors, H. W., Caldwell, C. H., Jackson, J. S. 2009. 12-month and lifetime prevalence of suicide attempts among black adolescents in the National Survey of American Life. Journal of the American Academy of Child and Adolescent Psychiatry. 48(3), 271-282.

80. Johnson, J. G., Harris, E., Spitzer, R. L., Williams, J. B. 2002. The patient health questionnaire for adolescents: validation of an instrument for the assessment of mental disorders among adolescent primary care patients. Journal of Adolescent Health. 30(3), 196-204.

81. Kang, E. H., Hyun, M. K., Choi, S. M., Kim, J. M., Kim, G. M., Woo, J. M. 2015. Twelve-month prevalence and predictors of self-reported suicidal ideation and suicide attempt among Korean adolescents in a web-based nationwide survey. The Australian and New Zealand Journal of Psychiatry. 49 (1), 47-53.

82. Kerr, M., Stattin, H., Biesecker, G., Ferrer-Wreder, L. 2003. Relationships with parents and peers in adolescence. In: Developmental psychology. Vol. 6. Lerner, R., Easterbrooks, M. A., Mistry, J. New York (NY): John Wiley \& Sons Inc, 395-419.

83. Kidger, J., Heron, J., Lewis, G., Evans, J., Gunnell, D. 2012. Adolescent self-harm and suicidal thoughts in the ALSPAC cohort: a self-report survey in England. BMC Psychiatry. 12:69. Available from: doi:10.1186/1471-244X-12-69 [accessed on 16.07.2018].

84. Kinchin, I., Doran, C. M. 2018. The Cost of Youth Suicide in Australia. International journal of environmental research and public health. 15(4), E672. Available from: doi:10.3390/ijerph15040672 [accessed on 09.07.2018].

85. Kokkevi, A., Rotsika, V., Arapaki, A., Richardson, C. 2011. Increasing self-reported suicide attempts by adolescents in Greece between 1984 and 2007. Social psychiatry and psychiatric epidemiology. 46(3), 231-237.

86. Kokkevi, A., Rotsika, V., Arapaki, A., Richardson, C. 2012. Adolescents' self-reported suicide attempts, self-harm thoughts and their correlates across 17 European countries. Journal of child psychology and psychiatry, and allied disciplines. 53(4), 381-389.

87. Koroḷeva, I., Mierina, I., Goldmanis, M., Sniḳere, S., Trapencieris, M. 2008. ESPAD 2007: Atkarību izraisošo vielu lietošanas paradumi un tendences skolēnu vidū. Rīga: Sabiedrības veselības aǵentūra.

88. Krug, E. G., Dahlberg, L. L., Mercy J. A., Zwi, A. B., Lozano R. 2002. World report on violence and health. Geneva: World Health Organization.

89. Lakey, C. E., Hirsch, J. K., Nelson, L. A., Nsamenang, S. A. 2014. Effects of contingent selfesteem on depressive symptoms and suicidal behavior. Death studies. 38(6-10), 563-570.

90. Langton, C. E., Berger, L. M. 2011. Family Structure and Adolescent Physical Health, Behavior, and Emotional Well-Being. Social Service Review. 85(3), 323-357.

91. Larsson, B., Sund, A. M. 2008. Prevalence, course, incidence, and 1-year prediction of deliberate self-harm and suicide attempts in early Norwegian school adolescents. Suicide \& life-threatening behavior. 38(2), 152-165.

92. Laukkanen, E., Rissanen, M. L., Honkalampi, K., Kylmä, J., Tolmunen, T., Hintikka, J. 2009. The prevalence of self-cutting and other self-harm among 13- to 18-year-old Finnish adolescents. Social psychiatry and psychiatric epidemiology. 44(1), 23-28.

93. Le, M. T., Nguyen, H. T., Tran, T. D., Fisher, J. R. 2012. Experience of low mood and suicidal behaviors among adolescents in Vietnam: findings from two national population-based surveys. Journal of Adolescent Health. 51(4), 339-348.

94. Lee, W. K. 2016. Psychological characteristics of self-harming behavior in Korean adolescents. Asian journal of psychiatry. 23, 119-124. Available from: doi:10.1016/j.ajp.2016.07.013. [accessed on 20.08.2018].

95. Lenzi, M., Vieno, A., Perkins, D. D., Santinello, M., Pastor, M., Mazzardis, S. 2012. Perceived neighborhood social resources as determinants of prosocial behavior in early adolescence. American journal of community psychology. 50(1-2), 37-49. 
96. Lesage, A. D., Boyer, R., Grunberg, F., Vanier, C., Morissette, R., Ménard-Buteau, C., Loyer, M. 1994. Suicide and mental disorders: a case-control study of young men. The American journal of psychiatry. 151(7), 1063-1068.

97. Levin, K. A., Currie, C. 2010. Family structure, mother-child communication, father-child communication, and adolescent life satisfaction: a cross-sectional multilevel analysis. Health Education. 110(3), 152-168.

98. Lieberman, M., Doyle, A. B., Markiewicz, D. 1999. Developmental patterns in security of attachment to mother and father in late childhood and early adolescence: associations with peer relations. Child development. 70(1), 202-213.

99. Liu, X. C., Chen, H., Liu, Z. Z., Wang, J. Y., Jia, C. X. 2017. Prevalence of suicidal behaviour and associated factors in a large sample of Chinese adolescents. Epidemiology and psychiatric sciences. 12, 1-10. Available from: doi:10.1017/S2045796017000488 [accessed on 01.08.2018].

100. LR Ministru kabinets. (2011). Ģimenes valsts politikas pamatnostādnes 2011.-2017.gadam: LR Ministru kabineta rīkojums Nr. 65, 18.02.2011.

101. LR Ministru kabinets. (2014). Sabiedrības veselības pamatnostādnes 2014.-2020. gadam: LR Ministru kabineta rīkojums Nr. 589, 14.10.2014.

102. Luoma, I., Puura, K., Tamminen, T., Kaukonen, P., Piha, J., Räsänen, E., Kumpulainen, K., Moilanen, I., Koivisto, A. M., Almqvist, F. 1999. Emotional and behavioural symptoms in 8-9year-old children in relation to family structure. European child \& adolescent psychiatry. 8 Suppl 4, 29-40.

103. Madge, N., Hawton, K., McMahon, E. M., Corcoran, P., De Leo, D., de Wilde, E. J., Fekete. S., van Heeringen, K., Ystgaard, M., Arensman, E. 2011. Psychological characteristics, stressful life events and deliberate self-harm: findings from the Child \& Adolescent Self-harm in Europe (CASE) Study. European child \& adolescent psychiatry. 20(10), 499-508.

104. Madu, S. N., Matla, M. P. 2004. Family environmental factors as correlates for adolescent suicidal behaviors in the Limpopo province of south Africa. Social Behavior \& Personality. 32(4), 341-354.

105. Maimon, D., Browning, C. R., Brooks-Gunn, J. 2010. Collective efficacy, family attachment, and urban adolescent suicide attempts. Journal of Health and Social Behavior. 51(3), 307-324.

106. Malone, P. A. 2007. The impact of peer death on adolescent girls: a task-oriented group intervention. Journal of social work in end-of-life \& palliative care. 3(3), 23-37.

107. Mark, L., Samm, A., Tooding, L. M., Sisask, M., Aasvee, K., Zaborskis, A., Zemaitiene, N., Värnik, A. 2013. Suicidal ideation, risk factors, and communication with parents. An HBSC study on school children in Estonia, Lithuania, and Luxembourg. Crisis. 34(1), 3-12.

108. Martin, G., Bergen, H. A., Richardson, A. S., Roeger, L., Allison, S. 2004. Sexual abuse and suicidality: gender differences in a large community sample of adolescents. Child abuse \& neglect. 28(5), 491-503.

109. McAdams, T. A., Rijsdijk, F. V., Narusyte, J., Ganiban, J. M., Reiss, D., Spotts, E., Neiderhiser J.M., Lichtenstein P., Eley, T.C. 2017. Associations between the parent-child relationship and adolescent self-worth: a genetically informed study of twin parents and their adolescent children. Journal of child psychology and psychiatry, and allied disciplines. 58(1), 46-54.

110. McMunn, A. M., Nazroo, J. Y., Marmot, M. G., Boreham, R., Goodman, R. 2001. Children's emotional and behavioural well-being and the family environment: findings from the Health Survey for England. Social science \& medicine. 53(4), 423-440.

111. Meyer, P. A., Garrison, C. Z., Jackson, K. L., Addy, C. L., McKeown, R. E., Waller, J. L. 1993. Undesirable Life-Events and Depression in Young Adolescents. Journal of Child \& Family Studies. 2(1), 47-60.

112. Meszaros, K., De Wals, S. 2011. Handbook on Psychology of Self-esteem. Hauppauge (NY): Nova Science Publishers, Inc.

113. Monto, M. A., McRee, N., Deryck, F. S. 2018. Nonsuicidal Self-Injury Among a Representative Sample of US Adolescents, 2015. American journal of public health. 108(8), 1042-1048.

114. Morey, C., Corcoran, P., Arensman, E., Perry, I.J. 2008. The prevalence of self-reported deliberate self harm in Irish adolescents. BMC public health. 8:79. Available from: doi:10.1186/1471-2458-8-79 [accessed on 30.08.2018].

115. Nanayakkara, S., Misch, D., Chang, L., Henry, D. 2013. Depression and exposure to suicide predict suicide attempt. Depression and anxiety. 30(10), 991-996. 
116. Newcombe, R. G. 1998. Two-sided confidence intervals for the single proportion: comparison of seven methods. Statistics in medicine. 17(8), 857-872.

117. Nkansah-Amankra, S., Walker, A. D., Clark, A. 2009. Suicidal Behaviors, Self Rated Health and Multiple Health Risk Behaviors Among Adolescents: Exploring New Perspectives With High School Students in Suicide Prevention Research. Annals of Epidemiology. 19(9), 669-670.

118. Nock, M. K., Borges, G., Bromet, E. J., Cha, C. B., Kessler, R. C., Lee, S. 2008. Suicide and Suicidal Behavior. Epidemiologic reviews. 30(1), 133-154.

119. Nock, M. K., Green, J. G., Hwang, I., McLaughlin, K. A., Sampson, N. A., Zaslavsky, A. M., Kessler, R. C. 2013. Prevalence, correlates, and treatment of lifetime suicidal behavior among adolescents: results from the National Comorbidity Survey Replication Adolescent Supplement. JAMA Psychiatry. 70(3), 300-310.

120. O'Connor, R. C., Rasmussen, S., Hawton, K. 2009. Predicting deliberate self-harm in adolescents: a six month prospective study. Suicide \& life-threatening behavior. 39(4), 364-375.

121. Olweus, D. 1994. Bullying at school: basic facts and effects of a school based intervention program. Journal of child psychology and psychiatry, and allied disciplines. 35(7), 1171-1190.

122. Overholser, J. C., Adams, D. M., Lehnert, K. L., Brinkman, D. C. 1995. Self-esteem deficits and suicidal tendencies among adolescents. Journal of the American Academy of Child and Adolescent Psychiatry. 34(7), 919-928.

123. Park, S., Lee, Y. 2016. Factors that Affect Suicide Attempts of Adolescents in Multicultural Families in Korea. International journal of environmental research and public health. 13(12), E1184.

124. Pasaules Veselības organizācija. 2015. SSK-10: starptautiskā slimību un veselības problēmu klasifikācija, 10. redakcija, 5. izdevums. Rīga: Slimību profilakses un kontroles centrs.

125. Patton, G. C., Coffey, C., Posterino, M., Carlin, J. B., Wolfe, R. 2000. Adolescent depressive disorder: a population-based study of ICD-10 symptoms. The Australian and New Zealand journal of psychiatry. 34(5), 741-747.

126. Peltzer, K., Pengpid, S. 2015. Early Substance Use Initiation and Suicide Ideation and Attempts among School-Aged Adolescents in Four Pacific Island Countries in Oceania. International journal of environmental research and public health. 12(10), 12291-12303.

127. Pompili, M., Serafini, G., Innamorati, M., Biondi, M., Siracusano, A., Di Giannantonio, M., Giupponi, G., Amore, M., Lester, D., Girardi, P., Möller-Leimkühler, A. M. 2012. Substance abuse and suicide risk among adolescents. European archives of psychiatry and clinical neuroscience. 262(6), 469-485.

128. Ponnet, K., Vermeiren, R., Jespers, I., Mussche, B., Ruchkin, V., Schwab-Stone, M., Deboutte, D. 2005. Suicidal behaviour in adolescents: associations with parental marital status and perceived parent-adolescent relationship. Journal of affective disorders. 89(1-3), 107-113.

129. Poorolajal, J, Darvishi, N. 2016. Smoking and Suicide: A Meta-Analysis. PLoS One. 11(7), e0156348. Available from: doi:10.1371/journal.pone.0156348 [accessed on 03.09.2018]

130. Portzky, G., De Wilde, E., van Heeringen, K. 2008. Deliberate self-harm in young people: differences in prevalence and risk factors between the Netherlands and Belgium. European child \& adolescent psychiatry. 17(3), 179-186.

131. Posner, K., Oquendo, M. A., Gould, M., Stanley, B., Davies, M. 2007. Columbia Classification Algorithm of Suicide Assessment (C-CASA): classification of suicidal events in the FDA's pediatric suicidal risk analysis of antidepressants. The American journal of psychiatry. 164(7), 1035-1043.

132. Pudule, I., Velika, B., Grīnberga, D., Gobiṇa, I., Villeruša, A. 2015. Latvijas skolēnu veselības paradumu pètījums: 2013./2014. mācību gada aptaujas rezultāti un tendences. Rīga: Slimību profilakses un kontroles centrs.

133. Pulmanis, T., Japeniña S., Taube, M. 2015. Psihiskā veselība Latvijā 2014. gadā: tematiskais zinojums. Rīga: Slimību profilakses un kontroles centrs.

134. Pulmanis, T., Japeniña, S., Taube, M. 2016. Psihiskā veselība Latvijā 2015. gadā: tematiskais ziņojums. Rīga: Slimību profilakses un kontroles centrs.

135. Pulmanis, T., Pelne, A., Taube, M. 2014. Psihiskā veselība Latvijā 2013. gadā: tematiskais zinojums. Rīga: Slimību profilakses un kontroles centrs.

136. Radloff, L. S. 1977. The CES-D scale: A self-report depression scale for research in the general population. Applied Psychological Measurement. 1(3), 385-401. 
137. Rancāns, E., Pulmanis, T., Taube, M., Springǵe, L., Velika, B., Pudule, I., Grīnberga, D. 2016. Prevalence and sociodemographic characteristics of self-reported suicidal behaviours in Latvia in 2010: A population-based study. Nordic journal of psychiatry. 70(3), 195-201.

138. Randell, B. P., Wang, W. L., Herting, J. R., Eggert, L. L. 2006. Family Factors Predicting Categories of Suicide Risk. Journal of Child and Family Studies. 15(3), 255-270.

139. Rhodes, A. E., Boyle, M. H., Bridge, J. A., Sinyor, M., Links, P. S., Tonmyr, L., Skinner, R., Bethell, J. M., Carlisle, C., Goodday, S., Hottes, T. S., Newton, A., Bennett, K., Sundar, P., Cheung, A. H., Szatmari, P. 2014. Antecedents and sex/gender differences in youth suicidal behavior. World journal of psychiatry. 4(4), 120-132.

140. Rosenberg, M. 1965. Society and The Adolescent Self-Image. Princeton: Princeton University Press.

141. Rothon, C., Goodwin, L., Stansfeld, S. 2012. Family social support, community "social capital" and adolescents' mental health and educational outcomes: a longitudinal study in England. Social psychiatry and psychiatric epidemiology. 47(5), 697-709.

142. Safer, D. J. 1997. Self-reported suicide attempts by adolescents. Annals of clinical psychiatry. 9(4), 263-269.

143. Samm, A., Tooding, L. M., Sisask, M., Kõlves, K., Aasvee, K., Värnik, A. 2010. Suicidal thoughts and depressive feelings amongst Estonian schoolchildren: effect of family relationship and family structure. European child \& adolescent psychiatry. 19(5), 457-468.

144. Sharma, B., Nam, E. W., Kim, H. Y., Kim, J. K. 2015. Factors Associated with Suicidal Ideation and Suicide Attempt among School-Going Urban Adolescents in Peru. International journal of environmental research and public health. 12(11), 14842-14856.

145. Silverman, M. M., Berman, A. L., Sanddal, N.D., O'carroll, P.W., Joiner, T.E. 2007. Rebuilding the Tower of Babel: a revised nomenclature for the study of suicide and suicidal behaviors. Part 2: suicide-related ideations, communications, and behaviors. Suicide \& life-threatening behavior. 37(3), 264-277.

146. Singh-Manoux, A., Adler, N. E., Marmot, M. G. 2003. Subjective social status: its determinants and its association with measures of ill-health in the Whitehall II study. Social science \& medicine. 56(6), 1321-1333.

147. Skrule, J. 2014. Priekšlaicìgas mirstības analīze. Potenciāli zaudētie mūža gadi Latvijā 2013. gadā. Rīga: Slimību profilakses un kontroles centrs.

148. Slimību profilakses un kontroles centrs. 2016. Pašnāvību riska faktori: informatīvs materiāls. Rīga: Slimību profilakses un kontroles centrs.

149. Sniķere, S., Trapencieris, M. 2016. ESPAD 2015: Atkarību izraisošo vielu lietošanas paradumi un tendences skolēnu vidū. Rīga: Slimību profilakses un kontroles centrs.

150. Spirito, A., Donaldson, D. 1998. Suicide and Suicide Attempts During Adolescence. In: Comprehensive Clinical Psychology: Volume 5. Children \& adolescents: Clinical formulation \& treatment. Oxford, England: Pergamon/Elsevier Science Ltd., 463-485.

151. Spring̣ge L. 2017. Vardarbības izraisītie veselības traucējumi bērniem un jauniešiem Latvijā: promocijas darbs: specialitāte - sabiedrības veselība un epidemiologija. Rīga: Rīgas Stradiña universitāte.

152. Squeglia, L. M., Jacobus, J., Tapert, S.F. 2009. The influence of substance use on adolescent brain development. Clinical EEG and neuroscience. 40(1), 31-38.

153. Stadler, C., Feifel, J., Rohrmann, S., Vermeiren, R., Poustka, F. 2010. Peer-victimization and mental health problems in adolescents: are parental and school support protective? Child psychiatry and human development. 41(4), 371-386.

154. Stockings, E., Degenhardt, L., Lee, Y. Y., Mihalopoulos, C., Liu, A., Hobbs, M., Patton, G. 2015. Symptom screening scales for detecting major depressive disorder in children and adolescents: a systematic review and meta-analysis of reliability, validity and diagnostic utility. Journal of affective disorders. 174, 447-463. Available from: doi: 10.1016/j.jad.2014.11.061 [accessed on 01.08.2018]

155. Susukida, R., Wilcox, H. C., Mendelson, T. 2016. The association of lifetime suicidal ideation with perceived parental love and family structure in childhood in a nationally representative adult sample. Psychiatry research. 237, 246-251. Available from: doi:10.1016/j.psychres.2016.01.033 [accessed on 01.08.2018]. 
156. Sweeting, H., Hunt, K. 2014. Adolescent socio-economic and school-based social status, health and well-being. Social science \& medicine. 121, 39-47. Available from: doi:10.1016/j.socscimed.2014.09.037 [accessed on 01.08.2018].

157. Šica, K., Pulmanis, T., Taube, M. 2017. Psihiskā veselība Latvijā 2016. gadā: tematiskais ziņojums. Rīga: Slimību profilakses un kontroles centrs.

158. Štāle, M., Treide, A., Rožkalne, G. 2016. Neinfekciju slimības - saslimstība, mirstība, riska faktori: situācija Latvijā 2006.-2015. gadā. Rīga: Slimību profilakses un kontroles centrs.

159. Tatnell, R., Kelada, L., Hasking, P., Martin, G. 2014. Longitudinal analysis of adolescent NSSI: the role of intrapersonal and interpersonal factors. Journal of abnormal child psychology. 42(6), $885-896$.

160. Taube, M., Damberga, I. 2009. Pašnāvības Latvijāa - situācija, perspektīvas, risinājumi. Rīga: Sabiedrības veselības ağentūra.

161. Tērauds, E., Andrēziņa, R., Kupča, B., Ancāne, G. 2009. Depresijas norise un ārstēšanas iespējas. Vadlīnijas. Rìga: Latvijas psihiatru asociācija.

162. The European Union Joint Action for Mental Health and Wellbeing. European Framework for Action on Mental Health and Wellbeing. 2016. Available from: https://ec.europa.eu/research/participants/data/ref/h2020/other/guides_for_applicants/h2020-SC1BHC-22-2019-framework-for-action_en.pdf [accessed on 09.07.2018]

163. Tidemalm, D., Runeson, B., Waern, M., Frisell, T., Carlström, E., Lichtenstein, P., Långström, N. 2011. Familial clustering of suicide risk: a total population study of 11.4 million individuals. Psychological medicine. 41(12), 2527-2534.

164. Tomori, M., Kienhorst, C. W., de Wilde, E. J., van den Bout, J. 2001. Suicidal behaviour and family factors among Dutch and Slovenian high school students: a comparison. Acta psychiatrica Scandinavica. 104(3), 198-203.

165. Tomori, M., Zalar, B. 2000. Characteristics of suicide attempters in a Slovenian high school population. Suicide \& life-threatening behavior. 30(3), 222-238.

166. Traylor, A. C., Williams, J. D., Kenney, J. L., Hopson, L. M. 2016. Relationships between Adolescent Well-Being and Friend Support and Behavior. Children \& Schools. 38(3), 179-186.

167. Trapencieris, M., Sniķere, S., Koroḷeva, I., Kārkliṇa, I. 2012. ESPAD 2011: Atkarību izraisošo vielu lietošanas paradumi un tendences skolēnu vidū. Rīga: Slimību profilakses un kontroles centrs.

168. Tsirigotis, K., Gruszczynski, W., Tsirigotis, M. 2011. Gender differentiation in methods of suicide attempts. Medical science monitor. 17(8), PH65-70.

169. Turecki, G., Brent D. A. 2016. Suicide and suicidal behaviour. Lancet. 387(10024), 1227-1239.

170. Turner, H. A., Finkelhor, D., Shattuck, A., Hamby, S. 2012. Recent victimization exposure and suicidal ideation in adolescents. Archives of pediatrics \& adolescent medicine. 166(12), 11491154.

171. Turunen, J. 2013. Family Structure, Gender, and Adolescent Emotional Well-Being. Journal of Divorce \& Remarriage. 54(6), 476-504.

172. Valsts bērnu tiesību aizsardzības inspekcija. 2018. Labklājības ministrijas Valsts bērnu tiesību aizsardzības inspekcijas 2017. gada publiskais pārskats. Rīga: Valsts bērnu tiesību aizsardzības inspekcija.

173. van Geel, M., Vedder, P., Tanilon, J. 2014. Relationship between peer victimization, cyberbullying, and suicide in children and adolescents: a meta-analysis. JAMA pediatrics. 168(5), 435-442.

174. Velika, B., Pudule, I., Grīnberga, D., Sprinğe, L., Gobiṇa, I. 2012. 2011. gada pètījums par Latvijas jauniešu bèrnībā gūto nelabvèlìgo pieredzi. Rīga: Slimību profilakses un kontroles centrs.

175. Vijayakumar, L. 2015. Suicide in women. Indian Journal of Psychiatry. 57(Suppl 2), S233-S238.

176. Vingilis, E. R., Wade, T. J., Seeley, J. S. 2002. Predictors of adolescent self-rated health. Analysis of the National Population Health Survey. Canadian journal of public health. 93(3), 193-197.

177. Wagner, B. M. 2009. Suicidal behavior in children and adolescents. New Haven: Yale University Press.

178. Wagner, B. M., Cole, R. E., Schwartzman, P. 1995. Psychosocial correlates of suicide attempts among junior and senior high school youth. Suicide \& life-threatening behavior. 25(3), 358-372. 
179. Waldrop, A. E., Hanson, R. F., Resnick, H. S., Kilpatrick, D. G., Naugle, A. E., Saunders, B. E. 2007. Risk factors for suicidal behavior among a national sample of adolescents: implications for prevention. Journal of traumatic stress. 20(5), 869-879.

180. Waldvogel, J. L., Rueter, M., Oberg, C. N. 2008. Adolescent suicide: risk factors and prevention strategies. Current Problems in Pediatric and Adolescent Health Care. 38(4), 110-125.

181. Wallen, J., Rubin, R. H. 1997. The role of the family in mediating the effects of community violence in children. Aggression and violent behavior. 2(1), 33-41.

182. Wang, J., Hughes, J., Murphy, G. T., Rigby, J. A., Langille, D. B. 2003. Suicidal behaviours among adolescents in northern Nova Scotia. Canadian journal of public health. 94(3), 207-211.

183. Wang, J., Iannotti, R. J., Luk, J. W., Nansel, T. R. 2010. Co-occurrence of victimization from five subtypes of bullying: physical, verbal, social exclusion, spreading rumors, and cyber. Journal of pediatric psychology. 35(10), 1103-1112.

184. Wang, P. W., Yen, C. F. 2017. Adolescent substance use behavior and suicidal behavior for boys and girls: a cross-sectional study by latent analysis approach. BMC psychiatry. 17(1), 392.

185. Watkins, R. L., Gutierrez, P. M. 2003. The relationship between exposure to adolescent suicide and subsequent suicide risk. 2002 Student Award Address. Suicide \& life-threatening behavior. 33(1), 21-32.

186. Webb, R. T., Kontopantelis, E., Doran, T., Qin, P., Creed, F., Kapur, N. 2012. Suicide risk in primary care patients with major physical diseases: a case-control study. Archives of general psychiatry. 69(3), 256-264.

187. Wild, L. G., Flisher, A. J., Lombard, C. 2004. Suicidal ideation and attempts in adolescents: associations with depression and six domains of self-esteem. Journal of Adolescence. 27(6), 611624.

188. Wolitzky-Taylor, K. B., Ruggiero, K. J., McCart, M. R., Smith, D. W., Hanson, R.F., Resnick, H. S., de Arellano, M. A., Saunders, B. E., Kilpatrick, D. G. 2010. Has Adolescent Suicidality Decreased in the United States? Data From Two National Samples of Adolescents Interviewed in 1995 and 2005. Journal of clinical child and adolescent psychology. 39(1), 64-76.

189. World Health Organization. 2018b. Mental Health Atlas 2017. Geneva: World Health Organization.

190. World Health Organization. 2000. Preventing suicide: a resource for teachers and other school staff. Geneva: World Health Organization.

191. World Health Organization. 2002. Multisite intervention study on suicidal behaviours - SUPREMISS: protocol of SUPRE-MISS. Geneva: World Health Organization.

192. World Health Organization. 2008. Preventing suicide: a resource for media professionals. Geneva: World Health Organization.

193. World Health Organization. 2013. Mental Health Action Plan 2013 - 2020. In: World Health Organization. Available from: https://www.who.int/iris/bitstream/10665/89966/1/9789241506021_eng.pdf?ua=1 [accessed on 28.06.2018]

194. World Health Organization. 2014a. Preventing suicide: a global imperative. Luxembourg: World Health Organization.

195. World Health Organization. 2014b. Suicide prevention: A resource for non-fatal suicidal behaviour case registration. Geneva: World Health Organization.

196. World Health Organization. 2015. The European Mental Health Action Plan 2013 - 2020. In: World Health Organization. Available from: http://www.euro.who.int/_data/assets/pdf_file/0020/280604/WHO-Europe-Mental-HealthAcion-Plan-2013-2020.pdf [accessed on 28.06.2018]

197. World Health Organization. 2016. Growing up unequal: gender and socioeconomic differences in young people's health and well-being: Health Behaviour in School-aged Children (HBSC) study, international report from the 2013/2014 survey. Copenhagen: World Health Organization Regional Office for Europe.

198. World Health Organization. 2017. Global Accelerated Action for the Health of Adolescents (AAHA!): guidance to support country implementation. Geneva: World Health Organization.

199. World Health Organization. 2018a. Suicide data. In: World Health Organization Mental health. Available from: www.who.int/mental_health/prevention/suicide/suicideprevent/en/ [accessed on 28.06.2018] 
200. Wu, P., Hoven, C. W., Liu, X., Cohen, P., Fuller, C. J., Shaffer, D. 2004. Substance use, suicidal ideation and attempts in children and adolescents. Suicide \& life-threatening behavior. 34(4), 408-420.

201. Xing, X. Y., Tao, F. B., Wan, Y. H., Xing, C., Qi, X. Y., Hao, J. H., Su, P. Y., Pan, H. F., Huang, L. 2010. Family factors associated with suicide attempts among Chinese adolescent students: a national cross-sectional survey. The Journal of adolescent health. 46(6), 592-599.

202. Zaborskis, A., Sirvyte, D., Zemaitiene, N. 2016. Prevalence and familial predictors of suicidal behaviour among adolescents in Lithuania: a cross-sectional survey. 2014. BMC Public Health. 16:554. Available from: doi: 10.1186/s12889-016-3211-x [accessed on 01.08.2018].

203. Zarrouq, B., Bendaou, B., Elkinany, S., Rammouz, I., Aalouane, R., Lyoussi, B., Khelafa, S., Bout, A., Berhili N., Hlal, H., Nejjari, C., El Rhazi, K. 2015. Suicidal behaviors among Moroccan school students: prevalence and association with socio-demographic characteristics and psychoactive substances use: a cross-sectional study. BMC Psychiatry. 15:284. Available from: doi:10.1186/s12888-015-0680-x [accessed on 16.07.2018].

204. Zhang, J., Tong, H. Q., Zhou, L. 2005. The effect of bereavement due to suicide on survivors depression: a study of chinese samples. Omega. 51(3), 217-227.

205. Zhang, Z. 2016. Model building strategy for logistic regression: purposeful selection. Annals of translational medicine. 4(6), 111.

206. Zubrick, S. R., Hafekost, J., Johnson, S. E., Lawrence, D., Saw, S., Sawyer, M., Ainley, J., Buckingham, W. J. 2016. Suicidal behaviours: Prevalence estimates from the second Australian Child and Adolescent Survey of Mental Health and Wellbeing. Australian \& New Zealand Journal of Psychiatry. 50(9), 899-910.

207. Zubrick, S. R., Hafekost, J., Johnson, S. E., Sawyer, M. G., Patton, G., Lawrence, D. 2017. The continuity and duration of depression and its relationship to non-suicidal self-harm and suicidal ideation and behavior in adolescents 12-17. Journal of affective disorders. 220, 49-56. 


\section{PUBLIKĀCIJAS UN TĒZES PAR DARBA TĒMU}

\section{Raksti starptautiski recenzētos žurnālos}

1. Springe, L., Pulmanis, T., Velika, B., Pudule, I., Grīnberga, D., Villeruša, A. 2016. Selfreported suicide attempts and exposure to different types of violence and neglect during childhood: Findings from a young adult population survey in Latvia. Scandinavian Journal of Public Health. 44, 411-417.

2. Rancāns, E., Pulmanis, T., Spring̣e, L., Velika, B., Pudule, I., Grīnberga, D. 2015. Prevalence and sociodemographic characteristics of self-reported suicidal behaviours in Latvia in 2010: A population-based study. Nordic Journal of Psychiatry. 70(3), 195-201.

\section{Raksti Latvijā recenzētos žurnālos}

1. Pulmanis, T., Trapencieris, M., Springge, L., Taube, M. 2015. Pusaudžu pašnāvnieciskā uzvedība Latvijā: pašnāvības plānu sakarība ar ǵimeni, vienaudžiem un skolu saistītiem faktoriem. Rīgas Stradiña universitātes zinātniskie raksti 2014. Rīga: Rīgas Stradiña universitāte

2. Pulmanis, T., Trapencieris, M., Sprinğge, L., Taube, M. 2014. Pusaudžu pašnāvnieciskā uzvedība Latvijā: sakarības ar atkarību izraisošo vielu lietošanu. Rīgas Stradinga universitātes zinātniskie raksti 2013. Rīga: Rīgas Stradiṇa universitāte

3. Pulmanis, T., Springgee, L., Trapencieris, M., Taube, M. 2013. Pašnāvnieciskās uzvedības mūža prevalence un tās izmaiņas dinamikā 15-16 gadus veciem pusaudžiem dzimumu grupās Latvijāà. Rìgas Stradiņa universitātes zinātniskie raksti 2012. Rīga: Rīgas Stradiṇa universitāte

4. Pulmanis, T., Taube, M, Pulmane, K., Trapencieris, M. 2012. Ģimenes, vardarbības un psihoemocionālo faktoru sakarības ar pašnāvības mēginājumiem 13-18 gadus vecu skolēnu vidū. Rìgas Stradiṇa universitātes zinātniskie raksti 2011. Rīga: Rīgas Stradiṇa universitāte

5. Skrule, J, Pulmanis T., Taube, M, Brig̣is, G.. 2010. Alkohola lietošana un suicidālās tieksmes skolēnu vidū. Rīgas Stradina universitātes zinātniskie raksti 2009. Rīga: Rīgas Stradiņa universitāte

\section{Tēzes starptautiskās konferencēs}

1. Pulmanis, T., Sprinǵge, L., Taube, M., Millere, I. 2019. Adolescent Self-Reported Lifetime Gender-Specific Suicidal Ideation in Latvia: Association with Peer-Related Factors. Rìga Stradiņš University International Conference on Medical and Health Care Sciences: Knowledge for Use in Practice. Abstracts, 675.

2. Rancans, E., Pulmanis, T., Kivite, A. 2017. Suicides and Suicidal Behaviours in $21^{\text {st }}$ Century in Latvia. WPA Inter Zonal Congress Electronic Abstract Book. Vilnius, Lithuania.

3. Pulmanis, T., Springe, L., Sile, L., Trapencieris, M., Taube, M. 2014. Association between adolescent self-reported lifetime suicide attempts and use of synthetic 
cannabinoids and other addictive substances in Latvia. Abstract book, $15^{\text {th }}$ European Symposium On Suicide and Suicidal Behaviour. Tallinn, Estonia.

4. Springe, L., Pulmanis, T., Pudule, I., Grinberga, D., Velika, B.,Villerusa, A. 2014. Association between exposure to physical and emotional neglect in childhood and selfreported lifetime suicide attempts in Latvian youth. Abstract book, $15^{\text {th }}$ European Symposium On Suicide and Suicidal Behaviour. Tallinn, Estonia.

5. Springe, L., Villerusa, A., Pulmanis, T., Pudule, I., Grinberga, D., Velika, B. 2013. Association between exposure to family violence in childhood and self-reported lifetime suicide attempts in Latvian youth. European Journal of Epidemiology. 28, Supplement 1, S213.

6. Pulmanis, T., Trapencieris, M., Taube, M. 2013. Adolescent self-reported lifetime suicide attempts in Latvia: family related factors. Atencion Primaria, 45, 123.

7. Pulmanis, T., Trapencieris, M., Taube, M. 2012. Adolescent Self-Reported Lifetime Suicidal Behaviours in Latvia. Youth in Latvia, Europe, Globe: Opportunities and Risks. Abstracts, 53.

\section{Tēzes konferencēs Latvijā}

1. Pulmanis, T., Trapencieris, M., Taube, M. 2014. Pusaudžu pašnāvnieciskā uzvedība Latvijā: pašnāvības plānu sakarības ar gímeni, vienaudžiem un skolu saistītiem faktoriem. 2014. gada Zinātniskās konferences tēzes. Rīga: Rīgas Stradiņa universitāte.

2. Pulmanis, T., Trapencieris, M., Taube, M. 2013. Pusaudžu pašnāvnieciskā uzvedība Latvijā: Sakarības ar atkarību izraisošo vielu lietošanu. 2013. gada Zinātniskās konferences tēzes. Rīga: Rīgas Stradiņa universitāte.

3. Pulmanis, T., Taube, M., Trapencieris, M., Vegnere, M. 2012. Pašnāvniecisko tieksmju prevalence 15-16 gadus veciem pusaudžiem Latvijā. 2012. gada Zinātniskās konferences tēzes. Rīga: Rīgas Stradiṇa universitāte. 


\section{PATEICĪBAS}

Patiesā cieņā vēlos izteikt visdziḷāko pateicību mana promocijas darba vadītājam psihiatram un profesoram Mārim Taubem par veiksmīgo sadarbību, atbalstu un mudināšanu tiekties uz mērḳi ne tikai promocijas darba izstrādes laikā, bet arī agrākos studiju posmos un karjeras attīstībā.

Izsaku pateicību Slimību profilakses un kontroles centra direktorei Ivetai Gavarei, Atkarības slimību riska analīzes nodaḷas vadītājai Aijai Pelnei un kolēgiem gan par iespēju izmantot ESPAD datu bāzi promocijas darba izstrādē, gan par manas personīgās profesionālās izaugsmes attīstību arvien jaunu mērķu sasniegšanai.

Īpašs paldies Mārcim Trapencierim par padziḷinātas intereses radīšanu, apmācību un nozīmīgiem padomiem darbā ar datiem un datu apstrādes metodēm.

Tāpat sirsnīgs paldies Sabiedrības veselības un sociālās labklājības fakultātes dekānei, profesorei Ingai Millerei par aktīvu motivēšanu, atbalstu un atbalstošu apstākḷu veicināšanu promocijas darba izstrādei.

Îpašu pateicību vēlos izteikt arī kolēgéei un draugam, Sabiedrības veselības un epidemiolog̣ijas katedras docentei Laumai Sprinğgei par nesavtīgo praktisko un emocionālo atbalstu promocijas darba izstrādes laikā, kā arī citiem katedras kolēgiem par palīdzību un atbalstu.

Sirsnīgs paldies arī manai ǵimenei un draugiem par ticību, iedrošinājumu, sapratni, atbalstu un pacietību. 
PIELIKUMI 
1. pielikums

\section{Anektas jautājumi un atbilžu varianti, kas izmantoti promocijas darbā}

1. Tavs dzimums:

- Vīrietis

- Sieviete

2. Kurā gadā esi dzimis/dzimusi?

19 _ gada _ _ēēnesī (atzīmē janvāri kā 01, februāri - 02 ... ... un decembri kā 12)

3. Cik bieži esi smēḳējis/-usi cigaretes PĒDĒJO 30 DIENU LAIKĀ?

- Nekad

- Mazāk par 1 cigareti nedēḷā

- Mazāk par vienu cigareti dienā

- 1-5 cigaretes dienā

- 6-10 cigaretes dienā

- 11-20 cigaretes dienā

- Vairāk par 20 cigaretēm dienā

4. Cik reizes savas dzīves laikā Tu esi apreibis/-usi no alkoholiskiem dzērieniem tā, ka ejot streipuļoji, nevarēji skaidri parunāt, vēmi vai nevarēji atcerēties, kas notika? (Atzīmē vienu atbildi (kvadrātu) katrā rindiṇā)

- Nevienu reizi

- 1-2 reizes

- 3-5 reizes

- 6-9 reizes

- 10-19 reizes

- 20-39 reizes

- 40 un vairāk reizes

5. Cik bieži savas dzīves laikā esi lietojis/-usi marihuānu vai hašišu? (Atzīmē vienu atbildi (kvadrātu) katrā rindiṇā)

- Nevienu reizi

- 1-2 reizes

- 3-5 reizes

- 6-9 reizes

- 10-19 reizes

- 20-39 reizes

- 40 un vairāk reizes

6. Cik bieži savas dzīves laikā esi lietojis/-usi ekstazī? (Atzīmē vienu atbildi (kvadrātu) katrā rindinā)

- Nevienu reizi

- 1-2 reizes

- 3-5 reizes

- 6-9 reizes

- 10-19 reizes

- 20-39 reizes

- 40 un vairāk reizes 
7. Cik bieži savas dzīves laikā esi lietojis/-usi amfetamīnus? (Atzīmē vienu atbildi (kvadrātu) katrā rindin̄ā)

- Nevienu reizi

- 1-2 reizes

- 3-5 reizes

- 6-9 reizes

- 10-19 reizes

- 20-39 reizes

- 40 un vairāk reizes

8. Cik bieži savas dzīves laikā esi lietojis/-usi LSD vai kādus citus halucinogēnus? (Atzīmē vienu atbildi (kvadrātu) katrā rindiṇā)

- Nevienu reizi

- 1-2 reizes

- 3-5 reizes

- 6-9 reizes

- 10-19 reizes

- 20-39 reizes

- 40 un vairāk reizes

9. Cik bieži savas dzīves laikā esi lietojis/-usi kreku? (Atzīmē vienu atbildi (kvadrātu) katrā rindin̄āa)

- Nevienu reizi

- 1-2 reizes

- 3-5 reizes

- 6-9 reizes

- 10-19 reizes

- 20-39 reizes

- 40 un vairāk reizes

10. Cik bieži savas dzīves laikā esi lietojis/-usi kokā̄nu? (Atzīmē vienu atbildi (kvadrātu) katrā rindin̄ā)

- Nevienu reizi

- 1-2 reizes

- 3-5 reizes

- 6-9 reizes

- 10-19 reizes

- 20-39 reizes

- 40 un vairāk reizes

11. Cik bieži savas dzīves laikā esi lietojis/-usi heroīnu? (Atzīmē vienu atbildi (kvadrātu) katrā rindin̄ā)

- Nevienu reizi

- 1-2 reizes

- 3-5 reizes

- 6-9 reizes

- 10-19 reizes

- 20-39 reizes

- 40 un vairāk reizes

12. Cik bieži savas dzīves laikā esi lietojis/-usi Spice? (Atzīmē vienu atbildi (kvadrātu) katrā rindin̄ā) 
- Nevienu reizi

- 1-2 reizes

- 3-5 reizes

- 6-9 reizes

- 10-19 reizes

- 20-39 reizes

- 40 un vairāk reizes

13. Kāds ir Tavas ǵimenes materiālais stāvoklis salīdzinājumā ar citām ǵimenēm Latvijā?

- Ievērojami labāks

- Labāks

- Mazliet labāks

- Apmēram tāds pats

- Mazliet sliktāks

- Sliktāks

- Ievērojami sliktāks

14. Kuri no zemāk minētajiem cilvēkiem dz̄̄vo kopā ar Tevi vienā gimenē? (Atzīmē visas atbilstošās atbildes)

- Dzīvoju viens

- Tēvs

- Patēvs

- Māte

- Pamāte

- Brālis/brāḷi

- Māsa/māsas

- Vecvecāki

- Citi tuvinieki

- Personas, kas nav tuvinieki

15. Cik bieži Tu vari teikt, ka šie apgalvojumi ir spēkā? (Atzīmē vienu atbildi (kvadrātu) katrā rindin̄ā)

15a: Man ir viegli saņemt emocionālo atbalstu no mātes un/vai tēva

- Gandrīz vienmēr

- Bieži

- Dažreiz

- Reti

- Gandrīz nekad

15b: Man ir viegli saņemt emocionālo atbalstu no mana labākā drauga/draudzenes

- Gandrīz vienmēr

- Bieži

- Dažreiz

- Reti

- Gandrīz nekad

16. Cik apmierināts/-a Tu parasti esi ar savu veselības stāvokli? (Atzīmē vienu atbildi (kvadrātu) katrā rindin̄ā)

- L,oti apmierināts

- Diezgan apmierināts

- Ne apmierināts, ne neapmierināts 
- Diezgan neapmierināts

- L,oti neapmierināts

17. Zemāk ir minēti apgalvojumi, kas varētu raksturot Tavas izjūtas pašam/pašai par sevi. Cik lielā mērā Tu tiem piekrīti? (Atzīmē vienu atbildi (kvadrātu) katrā rindin̄ā)

17a: Kopumā esmu ar sevi apmierināts/-a.

- Pilnīgi piekrītu

- Piekrītu

- Nepiekrītu

- Nepavisam nepiekrītu

17b: Reizēm domāju, ka nekam nederu.

- Pilnīgi piekrītu

- Piekritu

- Nepiekrītu

- Nepavisam nepiekrītu

17c: Uzskatu, ka man ir daudzas labas īpašības.

- Pilnīgi piekrītu

- Piekrītu

- Nepiekrītu

- Nepavisam nepiekrītu

17d: Spēju visu darīt tikpat labi, kā vairums cilvēku.

- Pilnīgi piekrītu

- Piekrītu

- Nepiekrītu

- Nepavisam nepiekrītu

17e: Domāju, ka man nav daudz ar ko lepoties.

- Pilnīgi piekrītu

- Piekrīu

- Nepiekrītu

- Nepavisam nepiekrītu

17f: Reizēm es patiešām jūtos nevērtīgs/-a.

- Pilnīgi piekrītu

- Piekrītu

- Nepiekrītu

- Nepavisam nepiekrītu

17g: Domāju, ka esmu vērtīgs cilvēks, vismaz līdzvērtīgs citiem.

- Pilnīgi piekrītu

- Piekrītu

- Nepiekrītu

- Nepavisam nepiekrìtu

17h: Vēlos, kaut man būtu vairāk pašcieņas.

- Pilnīgi piekrītu

- Piekrītu

- Nepiekrītu 
- Nepavisam nepiekrītu

17i: Vispār sliecos uzskatīt sevi par neveiksminieku.

- Pilnīgi piekrītu

- Piekrītu

- Nepiekrītu

- Nepavisam nepiekrītu

17j: Es pret sevi izturos pozitīvi.

- Pilnīgi piekrītu

- Piekrītu

- Nepiekrītu

- Nepavisam nepiekrītu

18. Cik bieži PĒDĒJO 7 DIENU laikā... (Atzīmē vienu atbildi (kvadrātu) katrā rindin̄ā)

18a: Tev bija zudusi apetīte, negribējās ēst.

- Reti vai nekad

- Dažreiz

- Bieži

- Gandrīz vienmēr

18b: Tev bija grūti koncentrēties tam, ko gribēji darīt.

- Reti vai nekad

- Dažreiz

- Bieži

- Gandrīz vienmēr

18c: juties nomākts/nomākta.

- Reti vai nekad

- Dažreiz

- Bieži

- Gandrīz vienmēr

18d: juti, ka ir jāpiepūlas un jāpiespiež sevi izdarīt to, kas jādara.

- Reti vai nekad

- Dažreiz

- Bieži

- Gandrīz vienmēr

18e: juties skumji.

- Reti vai nekad

- Dažreiz

- Bieži

- Gandrīz vienmēr

18f: nespēji darīt savu darbu (mājās, darbā, skolā).

- Reti vai nekad

- Dažreiz

- Bieži

- Gandrīz vienmēr 
19. Vai kāds no Taviem ǵimenes locekḷiem ir mēginājis izdarīt pašnāvību? (Atzīmē, lūdzu, vienu atbildi katrā rindiņā!)

- Jā, dzīves laikā

- Jā, pēdējo 12 mēnešu laikā

- $\mathrm{Ne}$

20. Vai kāds no Taviem ǵimenes locekḷiem ir izdarījis pašnāvību? (Atzīmē, lūdzu, vienu atbildi katrā rindin̄ā!)

- Jā, dzīves laikā

- Jā, pēdējo 12 mēnešu laikā

- $\mathrm{Ne}$

21. Vai kāds no Taviem draugiem vai paziņām ir mēǵinājis izdarīt pašnāvību? (Atzīmē, lūdzu, vienu atbildi katrā rindin̄ā!)

- Jā, dzīves laikā

- Jā, pēdējo 12 mēnešu laikā

- $\mathrm{Nē}$

22. Vai kāds no Taviem draugiem vai paziṇām ir izdarījis pašnāvību? (Atzīmēe lūdzu, vienu atbildi katrā rindiņā!)

- Jā, dzīves laikā

- Jā, pēdējo 12 mēnešu laikā

- $\mathrm{Ne}$

23. Vai Tu esi pārdomājis/-usi konkrētu veidu, vietu vai rīcību pašnāvības izdarīšanai? (Atzīmē, lūdzu, vienu atbildi katrā rindiṇā!)

- Jā, dzīves laikā

- Jā, pēdējo 12 mēnešu laikā

- $\mathrm{Ne}$

24. Vai esi piedzīvojis/-usi un cik reižu savas dzīves laikā kaut ko no sekojošā? (Atzīmē vienu atbildi (kvadrātu) katrā rindiṇā)

24a: mēgeinājis izdarīt pašnāvību.

- Nekad

- Vienu reizi

- Divas reizes

- 3-4 reizes

- 5 vai vairāk reizes

25. Vai Tu esi piedzīvojis/-usi kaut ko no sekojošā? (Atzīmē vienu atbildi katrā rindiṇā)

25a: Tiku iesaistīts fiziskā vardarbībā savās mājās, kurā piedalījās arī kāds pieaugušais.

- Jā, dzīves laikā

- Jā, pēdējo 12 mēnešu laikā

- Nē

25b: Piedzīvoju seksuālu uzmākšanos, kurā bija iesaistīts kāds pieaugušais ǵimenes loceklis.

- Jā, dzīves laikā

- Jā, pēdējo 12 mēnešu laikā

- $\mathrm{Ne}$ 
26. Lūdzu, novērtē sekojošās situācijas, vai tādas ir bijušas Tavā klasē klases biedru starpā! (Atzīmē vienu atbildi (kvadrātu) katrā rindiṇā).

26a: Klases biedri mani ir apsaukājuši.

- Nekad

- Reti

- Vidēji bieži

- Bieži

- Vienmēr 
RSU Ẽtikas komitejas lēmums

Veidlapa Nr. E-9 (2)

\section{RSU ETIKAS KOMIIEJAS LEMUMS}

Riza, Dzirciema icla 16, LV-1007

Td. 67409101

Komitejas sastâvs
Kvalifikācija

Nodarboకanăs

1 Asoc, prof. Olafs Brūvers

Profesore Vija Silc

Docente Sana Purvipa

4 Asoc. prof. Voldemãrs Arnis

5 Profesore Rę̧ina Kleina

6 Asoc, prof. Guntars Pupelis

7. Asoc. prof. Viesturs Liguts

$\begin{array}{cl}\text { Dr.theo. } & \text { teologs } \\ \text { Dr.phil. } & \text { filozofs } \\ \text { Dr.med. } & \text { farmakologs } \\ \text { Dr.biol. } & \text { rehabilitolegs } \\ \text { Dr.med. } & \text { patalogs } \\ \text { Dr.med. } & \text { kirurgs } \\ \text { Dr.med. } & \text { toksikologs }\end{array}$

\section{Pieteikuma icsnicdzcis: Toms Pilmanis Medicinıs fakultăte, doktorantûn \\ PêTiuma nosaukums: $\quad$ Ar pahãvniecisko uzvedibu saistitie faktori pusaudiu vidũ Latijä" \\ lenniegšanas datuns: $\quad 30.10 .203$. \\ Pễijuma protokols: $\quad$ Izskatot tugstâk minềtâ pêttijumapieteikuma materiālus (pnotokolu) ir redrams, ka pẽtīuma mērkis ick sasnicgts veicot pacientu (dalỉbnieku) mediciniskăs

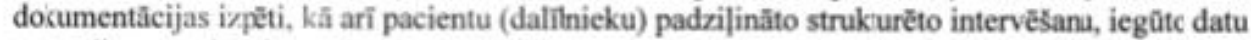 apstrâdi un analìi kỉ arĩ izsakot prickslikumus. Personu (pacientu dalỉbnieku) datı aizsarúzỉba,

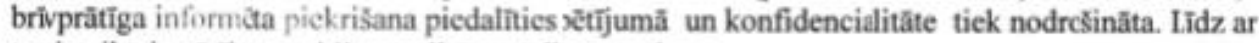 to jieteiktais pētijums atbilst medicinas ẽtihas prasibăm.}

Izskaidrošanas formulārs: ir

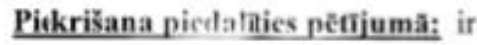

Kemitejas lêmums: $\quad$ piekrist pẽtijumam

Kamitejas prickšsč̣̂̃tajis Olafs Brûvers Tituls: Dr. miss, asoc. prof.

Pasaksts

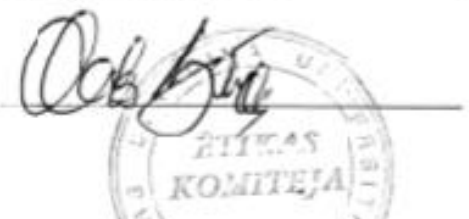

Eticas komitejas sẽ des datums: $31.10-2013$ 